VOLUM I 


\section{LA MÚSICA A LA CATEDRAL DE GIRONA DURANT LA PRIMERA MEITAT DEL SEGLE XIX}

Tesi Doctoral de MONTIEL GALDON I ARRUÉ

Dirigida pel Doctor Josep Maria Gregori Cifré

Departament d'Història de l'Art

Facultat de Filosofia i Lletres

Universitat Autònoma de Barcelona

Barcelona, 2003 
El Dr. Josep Maria Gregori i Cifré , director de la tesi

\section{LA MÚSICA A LA CATEDRAL DE GIRONA DURANT LA PRIMERA MEITAT DEL SEGLE XIX}

n'autoritza la lectura 
ÍNDEX GENERAL 


\section{VOLUM I}

\section{PREÀMBUL}

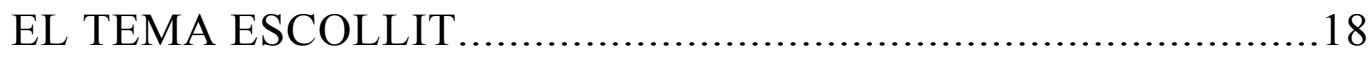

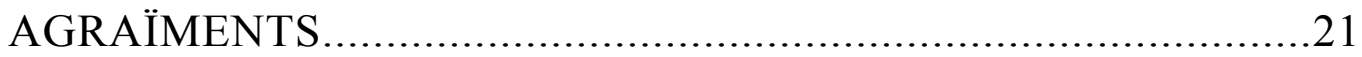

\section{INTRODUCCIÓ}

\section{FONTS GENERALS}

1. L'Arxiu Capitular de la Catedral de Girona..........................25

a) Llibres de Resolucions Capitulars..............................25

b) Llibres de Comptes de l'Obra.....................................27

c) Llibre de Noms i Cognoms.......................................28

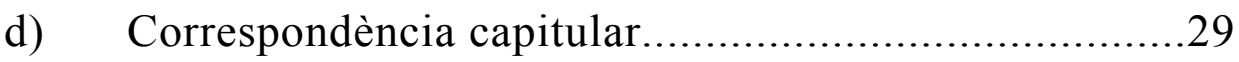

e) Llibres de la comunitat de beneficiats........................29

e.1. Possessions i òbits 1746-1836

f) Consueta de l'organista Antoni Guiu............................30

2. Altres arxius consultats.......................................................

a) L'Arxiu Parroquial de Sta. Maria del Pi de Barcelona

a.1. Determinacions de la Comunitat, anys 1834-1874

a.2. Capsa I, no 141: història capella de música Sta. Maria del Pi

a.3. Capsa II, $\mathrm{n}^{\circ}$ 142: història capella música Sta. Maria del Pi

b) L'Arxiu Episcopal de Vic............................................

c) L'Hemeroteca de l'Arxiu Municipal de la Ciutat de

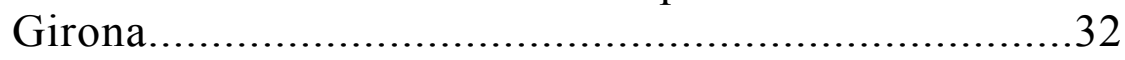

c.1. Gaseta del Corregiment de Girona

c.2. El Correo de Gerona

c.3. Boletín Oficial de la Provincia

c.4. El Postillón 
FONTS MUSICALS: PARTITURES

1. L'Arxiu Capitular de la Catedral de Girona..........................33

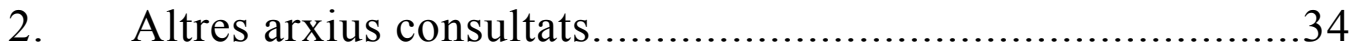

a) L'Arxiu Parroquial de Sta. Maria del Pi de Barcelona

b) L'Arxiu de l'Orfeó Català

c) L’Arxiu Històric de la Biblioteca de Catalunya: secció de manuscrits

\section{ESTAT DE LA QÜESTIÓ}

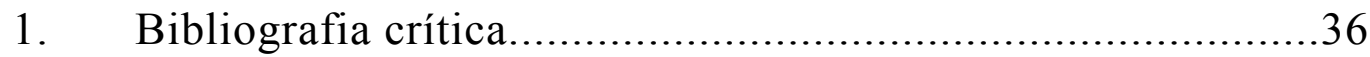

a) El fet musical a les comarques gironines en el lapse de temps 1800-1936................................36

b) El órgano y los organistas de la Catedral de Gerona durante los siglos XIV-XVI...........................57

c) Diccionario biográfico-bibliográfico de efemérides de músicos españoles.

d) Cien músicos célebres españoles................................62

e) Gran Enciclopèdia de la Música.................................64

f) Història de la Música Catalana, Valenciana i Balear.69

\section{METODOLOGIA GENERAL}

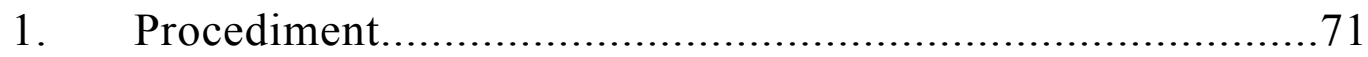

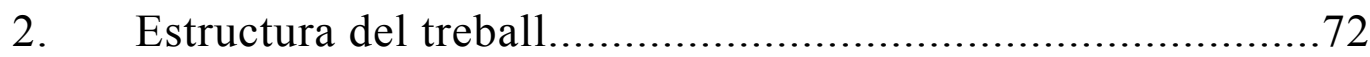

3. Criteris en la transcripció de manuscrits.............................75

\section{METODOLOGIA APLICADA A L'ANÀLISI MUSICAL}

1. Criteris per a la selecció de les obres.................................76

2. Criteris de transcripció i revisió crítica de les obres..............79

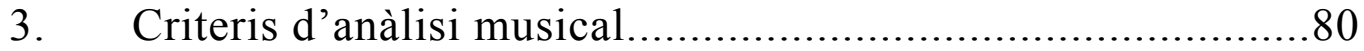


SIGLES I ABREVIATURES

1. Sigles generals. 82

a) Dels arxius consultats

b) De les fonts de l'Arxiu Capitular de la Catedral de Girona

2. Abreviatures .82

\section{CAPÍTOL I}

MARC HISTÒRIC: GIRONA A LA PRIMERA MEITAT DEL SEGLE XIX .87

\section{CAPÍTOL II}

LA CAPELLA DE MÚSICA DE LA CATEDRAL DE GIRONA DURANT LA PRIMERA MEITAT DEL SEGLE XIX.............109

COMPOSICIÓ GENERAL DE LA CAPELLA.............................109

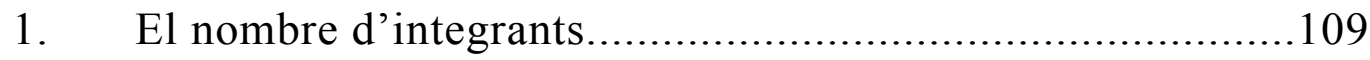

2. Els músics clergues beneficiats.........................111

a) Els beneficis.......................................111

b) Canvis en els beneficis...............................113

3. Els músics seglars pertanyents a la capella........................114

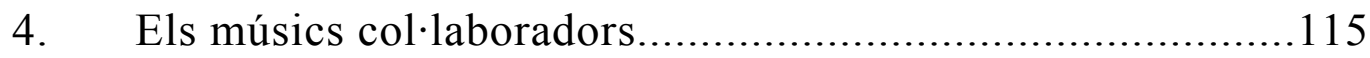

PAUTES DE FUNCIONAMENT DE LA CAPELLA...................120

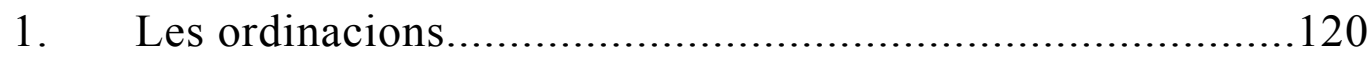

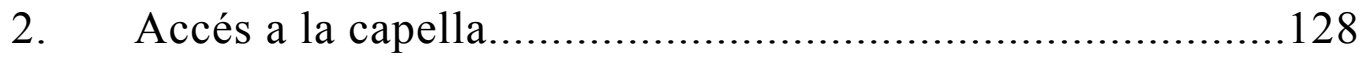

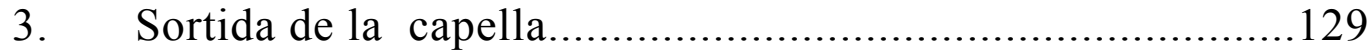

4. Permisos, malaltia i jubilació dels músics..........................130 
1. Funcions extraordinàries: festius i dominiques.............133

a) Consideracions generals.............................133

b) Algunes de les festivitats més importants.............135

b.1. Processó de St. Narcís del divuit de març.......136

b.2. Corpus.....................................137

b.3. L'Assumpta.................................139

b.4. St. Narcís del vint-i-nou d'octubre..............140

b.5. Tots Sants i Difunts...........................141

b.6. La Puríssima...................................141

b.7. La Passió........................................142

2. Variacions de les cerimònies en casos concrets..................143

a) Coincidència de funcions en llocs diferents...............143

c) Canvis produïts per situacions meteorològiques

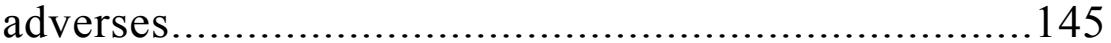

c) Altres circumstàncies que modifiquen la normativa litúrgica.

3. El cant del Te Deum amb motiu de diades o celebracions especials en la catedral de Girona.

a) Pregàries i accions de gràcies per epidèmies.............151

b) Recepció de tropes a la catedral...............................152

d) Visita a Girona del rei Carles IV ..............................154

e) Proclamació del rei Ferran VII.................................157

f) Assalt a la ciutat, primer setge i fugida de les tropes franceses............................................................. 158

g) Segon setge i presa de la ciutat..................................161

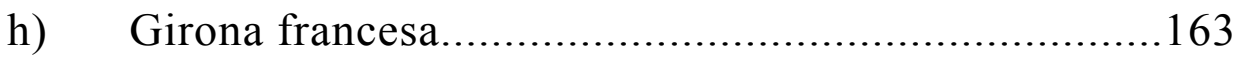

i) Rendició francesa i tornada de Ferran VII.................166

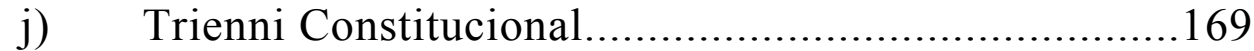


k) Retorn a l'absolutisme..........................................171

1) Actes relacionats amb pontífexs..............................172

m) Te Deum relacionats amb la reina.............................173

n) Actes realitzats en el període constitucional i de desamortitzacions.................................................... 175

4. Col-laboracions de la capella de música amb entitats i institucions religioses.

a) Parròquies, convents i comunitats religioses de la ciutat.

b) Parròquies, convents i comunitats religioses de fora de la ciutat.................................................180

5. Actes demanats per l'ajuntament......................... 182

6. Col·laboracions dels músics de la catedral en activitats musicals civils. 184

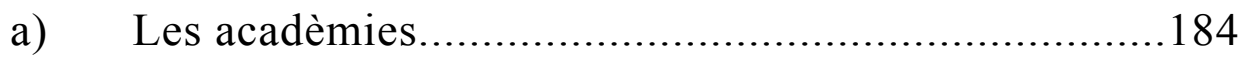

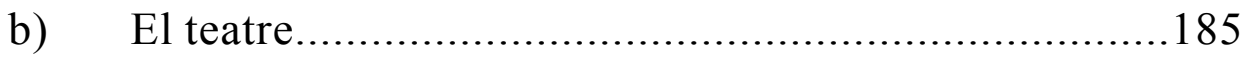

PERÍODES DE CRISI EN EL FUNCIONAMENT DE LA

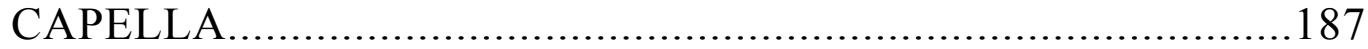

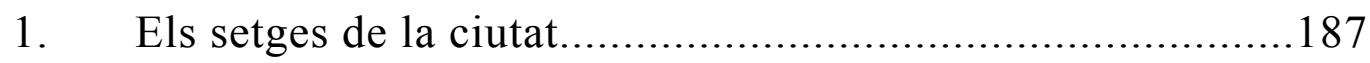

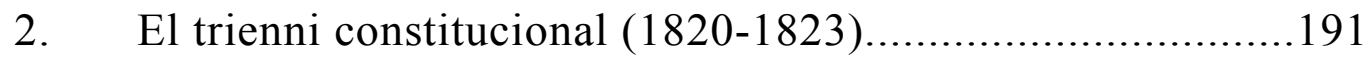

3. Les grans desamortitzacions (1836-1851)........................195

RECURSOS INSTRUMENTALS I MATERIALS DE LA

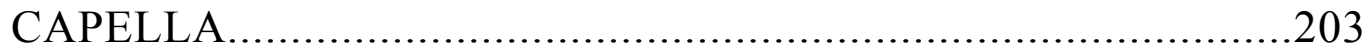

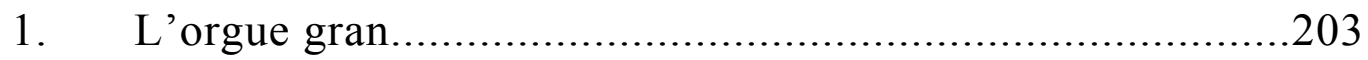

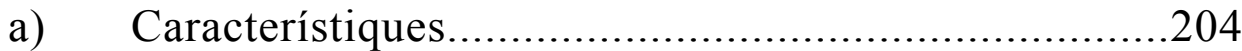

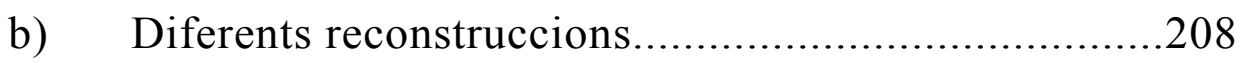

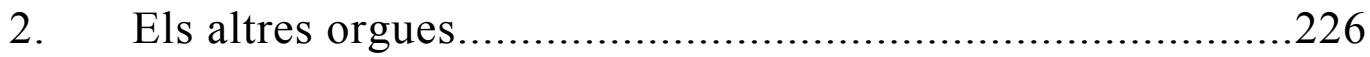


a) L'orgue petit o de semidobles..................................226

b) L'orgue de la capella de l'Esperança.........................228

c) L'orguenet portàtil..............................................229

3. Altres instruments de la capella.....................................232

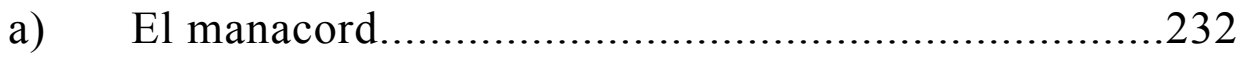

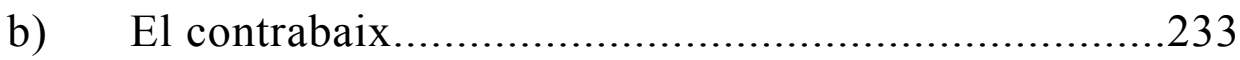

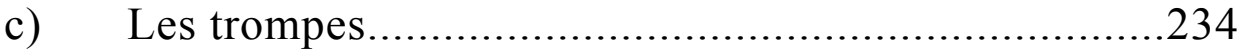

d) Els ministrers.....................................235

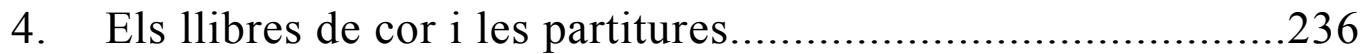

5. Vivendes propietat del capítol..........................................240

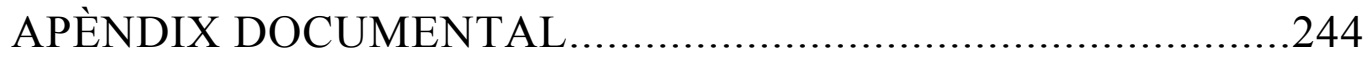

1. - Proposta de canvi en l'hora de les matines, del 23 de desembre de $1805 \ldots \ldots \ldots \ldots \ldots \ldots \ldots \ldots \ldots \ldots \ldots . . .244$

2. - Carta del canonge Rabal, del 27 de gener de 1806....245

3. - Documents relacionats amb els setges.......................247

4. - Supressió oficial de les capelles de música, del 20 d'octubre de $1842 \ldots \ldots \ldots \ldots \ldots \ldots \ldots \ldots \ldots \ldots \ldots \ldots \ldots . .252$

5. - Administració de 48000 reals, del 19 de desembre de $1842 \ldots \ldots \ldots \ldots \ldots \ldots \ldots \ldots \ldots \ldots \ldots \ldots \ldots \ldots \ldots . . . . .254$

6. - "Informe reducido" sobre l'estat de l'orgue i la seva restauració, per l'orguener Honorat Grinda, del 5 de maig de $1826 \ldots \ldots \ldots \ldots \ldots \ldots \ldots \ldots \ldots \ldots \ldots \ldots \ldots \ldots \ldots \ldots \ldots \ldots \ldots . . .257$

7. - Pressupost de restauració d'Honorat Grinda, del 8 de maig de $1826 \ldots \ldots \ldots \ldots \ldots \ldots \ldots \ldots \ldots \ldots \ldots \ldots \ldots . . .259$

8. - Acta del canvi de lloc de l'orgue, del 15 de juny de

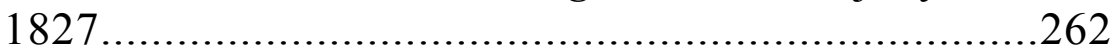

9. - Carta de'n Mateu Ferrer, del 24 de març de 1830....264 


\section{VOLUM II}

\section{CAPÍTOL III}

INTEGRANTS DE LA CAPELLA DE MÚSICA

MESTRES DE CAPELLA I ESCOLANS DE LA CATEDRAL

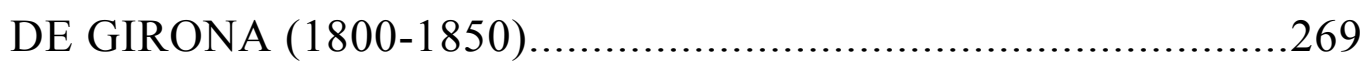

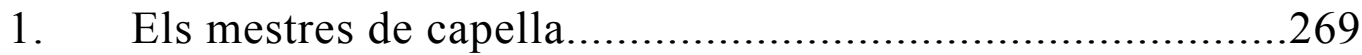

a) La plaça de mestre de capella...................................269

a.1. Accés a la plaça............................................269

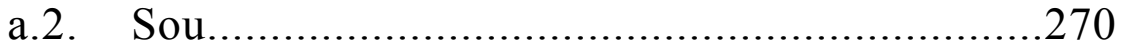

b) Obligacions del mestre de capella...........................271

c.1. Direcció musical de la capella........................271

c.2. Composició d'obres noves.............................273

c.3. Educació i cura dels infants de cor..................276

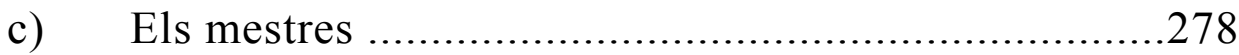

c.1. Rafael Compta (1794-1814).........................279

c.2. Antoni Guiu, mestre interí (1815)..................281

c.3. Josep Quilmetas, mestre interí (1816).............282

c.4. Honorat Verdaguer (1816-1819)...............283

c.5. Antoni Coderc, aspirant a la plaça...............293

c.6. Ramon Bassas, mestre interí (1819).............293

c.7. Jaume Joan Lleys (1820-1821)................295

c.8. Josep Quilmetas, mestre interí (1822)..........299

c.9. Jaume Joan Lleys (1823)...............................300

c.10. Tomàs Riu, mestre interí (1824)......................304

c.11. Josep Barba (1823-1850)......................306

d) Els mestres d'altres períodes...............................321

d.1. Francesc Juncà (1774-1780)...........................321

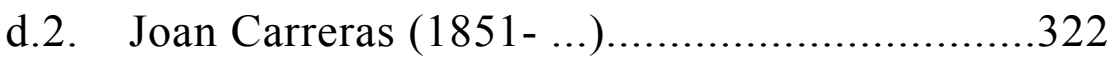

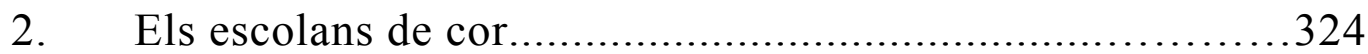


a) Informacions diverses referents als escolans.........324

a.1. Accés a la capella i sortida...................324

a.2. Vivenda, alimentació, vestits i medecines.......328

a.3. Ensenyaments musicals i doctrina cristiana....333

a.4. Queixes dels escolans......................335

a.5. Informacions disperses......................337

b) Lloc d'origen dels escolans.............................. 337

c) Escolans que amb els anys formarien part de la capella.

ORGANISTES, MANXADORS I ORGUENERS

DE LA CATEDRAL DE GIRONA (1800-1850). .343

1. Els organistes .343

a) La plaça d'organista...........................................343

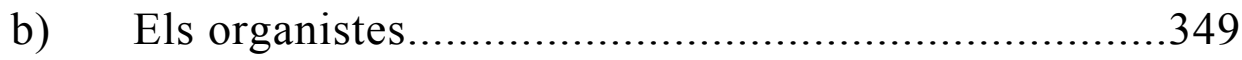

b.1. Josep Prat (1781-1804)............................349

b.2. Domènec Ferrer i Arquimbau, substitut

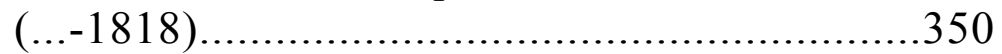

b.3. Lluís Vallllosera, aspirant (1804)..................353

b.4. Ramon Gomis, aspirant (1804)....................353

b.5. Antoni Guiu (1804-1827)..........................354

b.6. Manel Casanovas, aspirant (1804)................386

b.7. Antoni Coderc, aspirant (1804)......................386

b.8. Marià Albert, aspirant (1804).......................387

b.9. Francesc Llanza, aspirant (1804)..................387

b.10. Francesc Monlluís, aspirant (1804)................388

b.11. Francesc Creuet, organista interí (1822-1824;

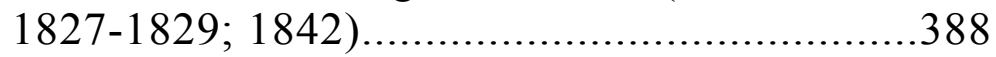

b.12. Francesc Peiró, aspirant (1829)................390

b.13. Vicenç Comas, aspirant (1829)......................391

b.14. Pere Busquets, aspirant (1829)......................391

b.15. Vicenç Paradell, aspirant (1829)....................391

b.16. Baltasar Dorda (1829-1833).......................392 
b.17. Pelegrí Baltasar (1833-1838)..........................395

b.18. Bernat Papell (1838-1842)...................400

b.19. Pedro Preciado, substitut (1842).....................403

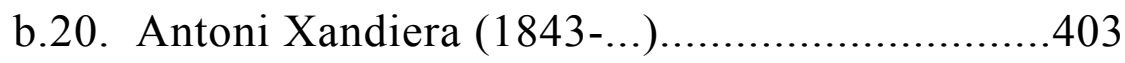

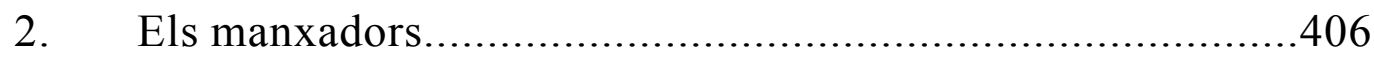

a) La plaça de manxador...............................................406

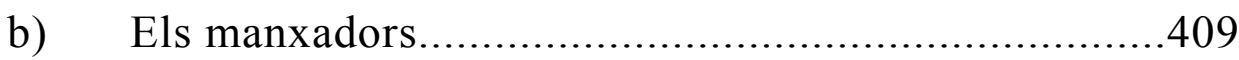

b.1. Miquel Baró (1799-1811)...............................409

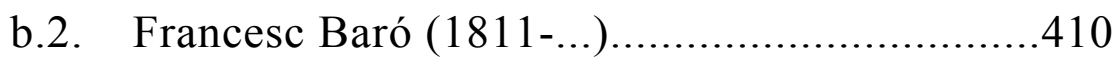

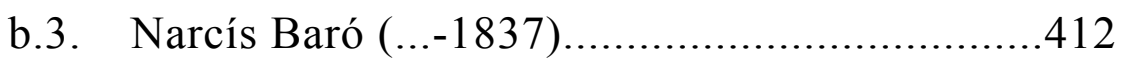

b.4. Teresa Baró (1837).........................................413

b.5. Joan Bosacoma (1837-...).............................413

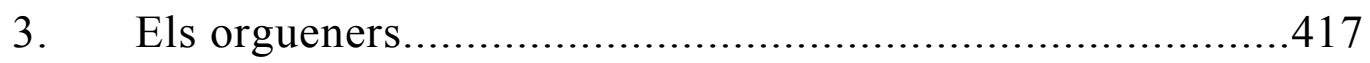

a) La plaça d'orguener................................................418

b) Els orgueners......................................................... 418

b.1. Francesc Vilella (1799-1816)........................418

b.2. Narcís Vilella (1816-1823).............................419

b.3. Pere Figueres (1823)...................................420

b.4. Honorat i Antoni Grinda (1826-1831).............420

b.5. Antoni Portell (1845)....................................422

b.6. Ramon Roquer (1846)..........................424

b.7. Antoni Portell (1847)......................................425

4. Taula dels organistes, manxadors i orgueners en relació a les principals restauracions de l'orgue gran.

CANTORS DE LA CATEDRAL DE GIRONA (1800-1850)........429

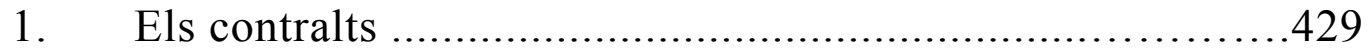

a) La plaça de contralt.................................................429

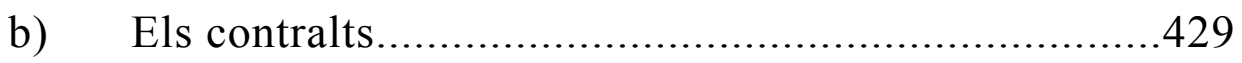

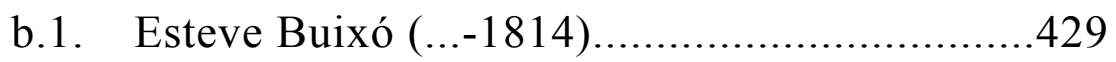


b.2. Ignasi Brusi, aspirant (1795).........................434

b.3. Jacint Freixedas (1795-1810).........................435

b.4. Francesc Riambau (1814)..............................437

b.5. Tomàs Riu (1814-1836)...................................438

b.6. Felip Comellas (1814-1819)............................444

b.7. Josep Fajó, aspirant (1814).............................448

b.8. Francesc Roura (1819-1825).........................449

b.9. Isidre Llussà, aspirant (1819).........................454

b.10. Joan Ponsatí, aspirant (1819)..........................454

b.11. Pere Preciado (1828-1850?)............................454

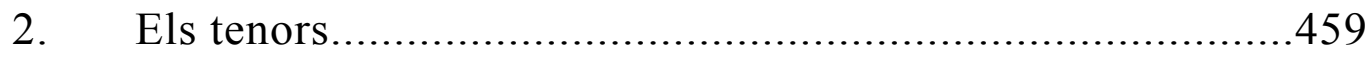

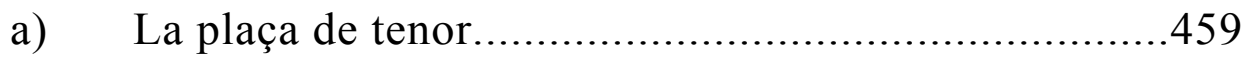

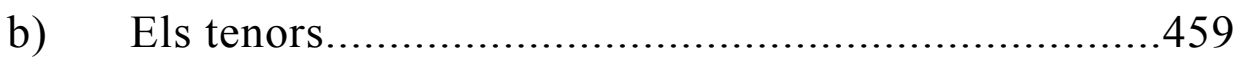

b.1. Josep Riumbau, aspirant (1796)......................459

b.2. Ignasi Brusi, aspirant (1796)...........................460

b.3. Bonaventura Feliu, aspirant (1796).................461

b.4 Bernat Bertran (1796-1815)..........................462

b.5. Domènec Ferrer i Arquimbau (1797-1818)......475

b.6. Josep Pagès (1816-1818)...............................480

b.7. Miquel Fossalba (1818-1850?)......................485

b.8. Francesc Creuet (1818-1850)..........................494

b.9. Martí Valls, aspirant (1818)...........................502

b.10. Francesc Serrat, aspirant (1818).....................503

b.11. Joan Folivà, aspirant (1818)...................504

b.12. Bernat Canals, aspirant (1818).................504

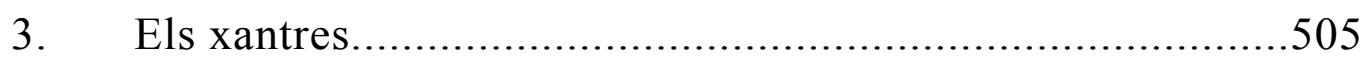

a) La plaça de xantre.................................................505

b) Les obligacions dels xantres...................................507

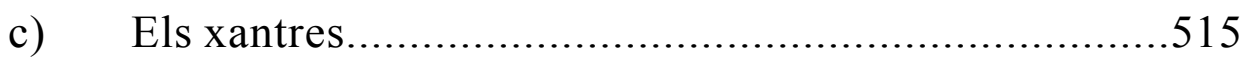

c.1. Lleó Antoni Santamaria (1798-1842)...............515

c.2. Ramon Aleix, aspirant (1801).................532 
c.3. Francesc Pagès $(1875-1814) \ldots \ldots \ldots \ldots \ldots \ldots . \ldots 533$

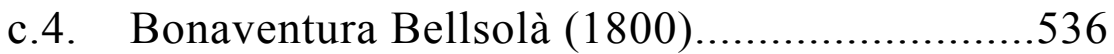

c.5. Joan Tarrés i Garcia (1797-1817)...................540

c.6. Josep Garcia (1801-1814)..............................544

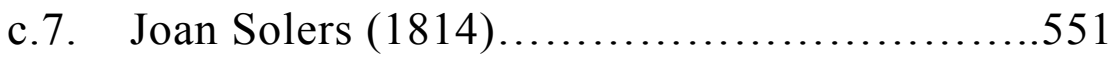

c.8. Feliu Pujol, aspirant $(1814,1815,1825)$.........553

c.9. Miquel Ferrer (1814-1838)..........................557

c.10 Domingo Vilageliu (1814).............................559

c.11. Ramon Virosta (1815-1847)..........................562

c.12. Jaume Virosta 1817-1822?)...........................565

c.13 Pedro Rubio (1840-1842?)..............................569

c.14. Ramon Vendrell (1831-1847?)........................570

c.15. Joan Bosacoma (1839-1844)..........................573

c.16. Joan Bruguera (1845-...).............................576

\section{MÚSICS DE CORDA DE LA CATEDRAL DE GIRONA}

1. Els músics de violí............................................................577

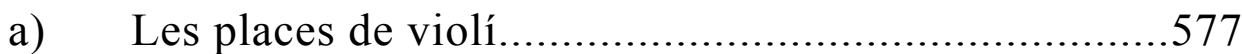

b) Els músics de violí laics.........................................579

b.1 Carles Quilmetas (1775-1834)......................579

b.2 Francesc Ortiz (1788-...)..............................586

c) Els músics de violí preveres beneficiats....................590

c.1. Miquel Policarp (1795-1815).........................590

c.2. Josep Quilmetas (1795-1798; 1815-1844)_.....595

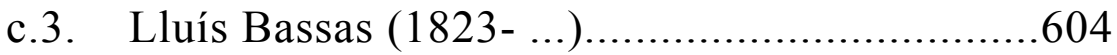

c.4. Carles Sipiera i Quilmetas (1826)..................607

c.5. Onofre Bassas (1833-1835)...........................608

c.6. Amerio Mias $(1835-\ldots) \ldots \ldots \ldots \ldots \ldots \ldots \ldots \ldots \ldots \ldots \ldots . . .609$

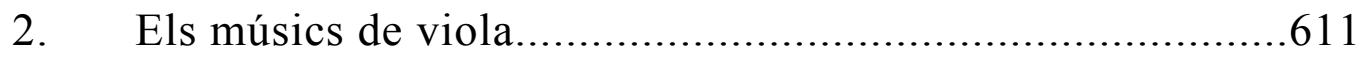

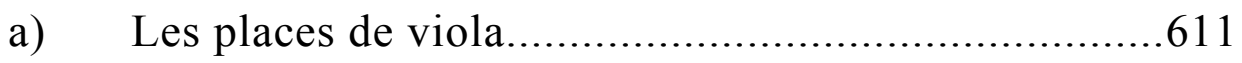




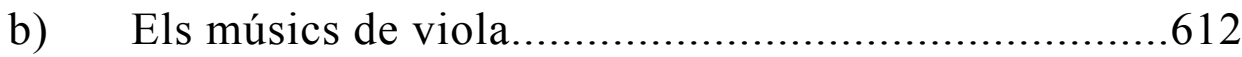

b.1. Segimon Ponsa (1787-1808)..........................612

b.2. Josep Serrat (1752-1802)............................619

b.3. Josep Quilmetas (1814-1815).......................623

b.4. Isidre Grau (1817-1819)................................623

b.5. Fèlix Pallès (1823)......................................626

b.6. Feliu Busquets (1823-1845).........................628

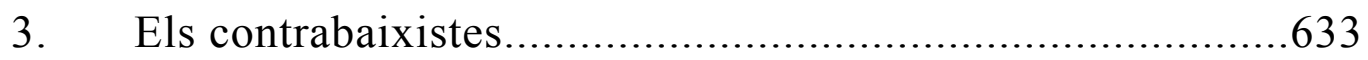

a) La plaça de contrabaixista........................................633

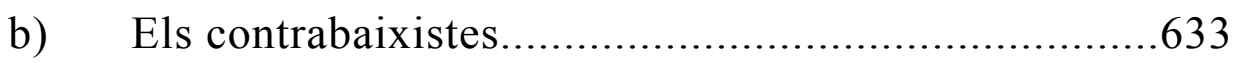

b.1. Miquel Albert (1795-1807)..........................633

b.2. Pere Bladó, aspirant (1805)..........................638

b.3. Antoni Illa (1814-1833?)..............................638

MÚSICS DE VENT DE LA CATEDRAL DE

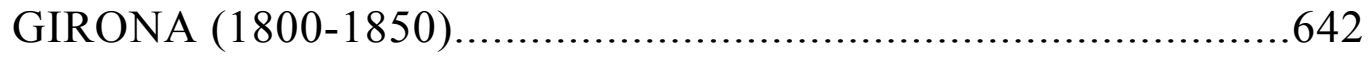

1. Informacions relatives a les places de vent......................642

2. Els músics de vent-fusta...............................642

a) Els beneficiats d'instruments de vent i alfullers.......642

a.1. Josep Guimat (1797-1815).................642

a.2. Narcís Vivern (1795-1816)...................644

a.3. Ramon Bassas (1815-1846)...................653

c) L'instrumentista de flauta, fagot i oboè

Romuald Huguet (1797-1817)......................660

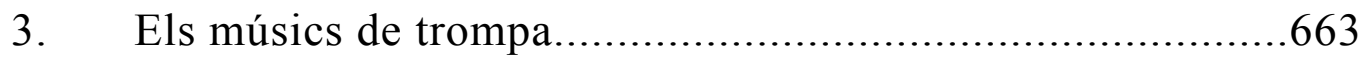

a) Les places de trompa..........................................663

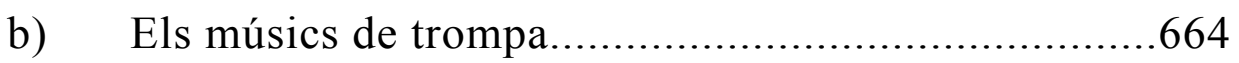

b.1. Tomas Blanc (1767-1807).............................664

b.2. Joan Mirambell (1783).................................667

b.3. Pere Illa (1794-1817).................................668

b.4. Francesc Riumbau, aspirant $(1803,1807) \ldots \ldots .677$ 
b.5. Joan Illa (1807-1830).......................679

b.6. Narcís Illa (1815-1831)................................682

b.7. Miquel Bosch (1830-...)...............................683

4. Els ministrers i altres col-laboradors.................................685

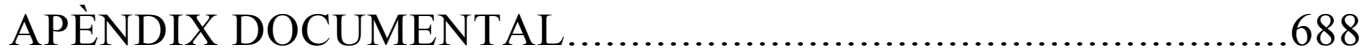

1. - Obligacions del mestre de capella pel que fa a la composició, del 4 de març de 1781 ................689

2. - Obligacions del mestre de capella pel que fa als escolans de cor, del 2 de gener de 1819

3. - Possessió del benefici de St. Pere i St. Pau pel mestre Honorat Verdaguer, 8 de febrer de 1817........692

4. - Carta del canonge Josep Joan Rodó, del 7 d'octubre de 1819 .

5. - Instruccions per a les oposicions de mestre de la catedral de Sevilla, del 17 de gener de 1829...696

6. - Carta del mestre Josep Barba, del 15 de juliol de 1847.

7. - Llibre de Noms i cognoms.

8. - Notícies de premsa "El Postillón". 712

9. - Acta de l'oposició de l'organista Antoni Guiu, del 23 de novembre de 1804 .

\section{VOLUM III}

\section{CAPÍTOL IV}

LES OBRES MANUSCRITES CONSERVADES D'AUTOR..717

\section{CAPÍTOL V}

\section{ANÀLISI DE LA MÚSICA INSTRUMENTAL}

QUATRO SONATAS, d'Albert (Miquel).

1. Estructura formal

2. Elements harmònics 
3. Elements melòdics i rítmics

4. Aspectes tímbrics

5. Textura

6. Elements expressius

7. Valoració estilística general

SINFONÍA PARA ORQUESTA OBLIGADA DE ÓRGANO, d'Antoni Guiu.

1. Estructura formal

2. Elements harmònics

3. Elements melòdics i rítmics

4. Aspectes tímbrics

5. Textura

6. Elements expressius

7. Valoració estilística general

TEMA CON VARIACIONES PARA EL VIOLONCELLO À TODA ORQUESTA, de Jaume Joan Lleys

1. Estructura formal

2. Elements harmònics

3. Elements melòdics i rítmics

4. Aspectes tímbrics

5. Textura

6. Elements expressius

7. Valoració estilística general

YNTRODUCCION Y VARIACIONES DE FLAUTA, PIANO Y FAGOTE OBLIGADOS, d'Antoni Guiu

1. Estructura formal

2. Elements harmònics

3. Elements melòdics i rítmics

4. Aspectes tímbrics 
5. Textura

6. Elements expressius

7. Valoració estilística general

\section{CAPÍTOL VI}

EDICIÓ CRÍTICA DE LES OBRES .776

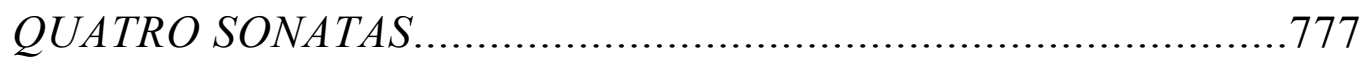

SINFONÍA CON ORQUESTA OBLIGADA DE ÓRGANO. 853

\section{VOLUM IV}

EDICIÓ CRÍTICA DE LES OBRES (CONTINUACIÓ) .993

TEMA CON VARIACIONES PARA VIOLONCELO. .994 YNTRODUCCION Y VARIACIONES DE FLAUTA, PIANO Y FAGOTE OBLIGADOS.

\section{CAPÍTOL VII}

CONCLUSIONS GENERALS

\section{APÈNDIX DE LÀMINES I DESPLEGABLES}

Reproducció del pressupost

Planta de la Catedral de Girona. 1193

Reproduccions de mostres dels quatre manuscrits transcrits 1194

Desplegable cronològic de la capella de música .1196

BIBLIOGRAFIA 
PREÀMBUL 


\section{EL TEMA ESCOLLIT}

En termes generals podem dir que el segle XIX és encara ara, un dels grans desconeguts del panorama musical i musicològic català. Si bé és cert que la gran inestabilitat de l'època, tant a nivell polític, econòmic com social, no era precisament la més favorable per a la creació artística, la vida continuava. Així doncs, i en la mesura que permetien les adverses circumstàncies, les esglésies i les catedrals seguiren celebrant les funcions religioses; les ciutats i els pobles se seguiren engalanant en motiu d'importants diades, de la mateixa manera que músics i compositors seguiren interpretant $\mathrm{i}$ creant obres noves. A més, moltes vegades aquestes manifestacions culturals eren fets vitals per a la cohesió social, tan necessària i important en els moments adversos.

El present treball té com a objectiu la contribució al coneixement de les capelles de música de principis del segle XIX. S'ha pres com a mostra l'estudi de la capella de música de la catedral de Girona, analitzant quines eren les pautes de funcionament, els mitjans econòmics i personals de què es disposava, i la producció musical realitzada, tant pel que fa a la composició com a la interpretació. Com exemple de l'activitat compositiva dels membres de la capella, transcric i analitzo quatre obres instrumentals.

Per a l'estudi de la capella de música de la catedral gironina, m'he centrat en el període de temps que va de l'any 1800 al 1850. Es podrien haver agafat altres dates tan encertades com aquestes, segons la justificació emprada. En principi, el mil vuit-cents significa l'entrada d'un nou segle, amb unes perspectives molt diferents de l'anterior. De l'altre costat dels Pirineus arriben aires de llibertat, igualtat $\mathrm{i}$ fraternitat, propulsats per la recent Revolució Francesa. Tot i 
que aquest ideari es veu estroncat a nivell polític pels desitjos imperialistes de Napoleó, una nova consciència i una nova manera de pensar es va estenent entre les classes populars. Mentrestant, una Catalunya debilitada per la recent Guerra Gran, sobretot la zona de Girona pel seu emplaçament geogràfic, es veu altra vegada immergida en conflictes bèl-lics, aquest cop contra els exèrcits napoleònics. Les escomeses s'allargarien fins l'any 1814.

Durant la primera meitat del segle XIX, la societat, la població i el pensament, es veuran sempre escindits en dos pols oposats i completament antagònics. D'una banda els nous corrents de llibertat que arriben de França, en part reflectits en les Corts de Cadis de 1812, i per un altre costat, l'absolutisme ofegant de Ferran VIIè ; un creixent liberalisme social i polític de ciutats i zones costaneres, enfront de la pagesia, amb els seus valors tradicionals; una població civil en constant canvi social i polític en oposició amb l'immobilisme en el funcionament d'estaments com l'eclesiàstic. A mode d'exemple, en la present tesi trobarem músics clergues molt crítics amb l'encarcarament de les normes de funcionament de la capella, i d'altres disposats a no canviar ni un bri de les pautes, legitimades pels cents d'anys de seguiment estàtic, sense transgredir-les mai. Aquestes i moltes altres dualitats que podem observar en aquesta època, deuen la seva existència a una intensa revolució social, política i cultural que s'està desenvolupant en el si més profund de la població. Efectivament, després d'aquest període res no tornarà a ser el mateix. Molts estaments desapareixeran, com és el cas de les capelles de música, conseqüència directa de la pèrdua sobtada i radical del poder econòmic i social de l'església. La pagesia, vertebradora de l'economia catalana durant segles, també veu anorreada la seva importància. Altres estaments, en canvi, experimentaran una puixança sense precedents, és el cas dels ajuntaments i els menestrals. 
Es pot considerar que aquest període tan revoltat fineix l'any 1840 , data en què acaba la Segona Guerra Carlina. I centrant-me més concretament en les capelles de música també podria agafar de data d'acabament l'any 1842, en què el ministre d'hisenda fa la recomanació que es suprimeixin les capelles de música per les despeses que generen. ${ }^{1}$ Tot $\mathrm{i}$ això, he preferit prendre com a data final de l'estudi, l'any 1850 . La raó principal és poder veure completat el procés de canvi social, i per percebre quines directrius apunta el desenvolupament del segon tombant de segle, que serà total $\mathrm{i}$ radicalment diferent. També hi ha una raó subjectiva (i purament estètica), consistent en deixar enllestit l'estudi de la capella de música la primera meitat del segle XIX. La revolució del pensament i les guerres del primer tombant de segle, cediran pas a un període de pau on fructificarà la consciència del sentiment català, $a m b$ la Renaixença, $i$ en què es produirà la Revolució Industrial a Catalunya amb tot un seguit de conseqüències econòmiques, socials i polítiques, que no tenen res a veure amb les circumstàncies de la primera meitat de segle. Però això, ja són figues d'un altre paner.

Aquest estudi s'ha basat per complet en la capella de música de la catedral de Girona, que ja en el segle XVIII tenia una de les dotacions personals més importants de la Península. En l'arxiu capitular de la catedral es conserven més de cinccentes obres datades en la primera meitat del segle XIX, de les quals en dues-centes setanta hi figura el compositor, essent la resta en principi anònimes. També cal tenir en compte les obres conservades en d'altres arxius, com el de la Biblioteca de Catalunya, on també s'hi troben obres de compositors de la capella gironina. Les obres foren venudes a la Diputació de

\footnotetext{
${ }^{1}$ Vegi's aquest document en el capítol II, en l'apartat dels "Períodes de crisi en el funcionament de la capella".
} 
Barcelona per Joan Carreras i Dagas ${ }^{2}$. L'ingent nombre de composicions provinent dels membres de la capella, ha estat una de les motivacions importants per a dur a terme aquesta recerca. Al volum d'obres conservades, cal adjuntar la valuosíssima informació que també hi ha a l'arxiu, en forma de llibres d'actes, llibres d'obra, llibres de beneficiats, etc., que proporcionen molts ítems referents al funcionament $\mathrm{i}$ als membres de la capella. La lectura, transcripció i filtració d'aquestes dades m'han donat una informació de gran vàlua per a explicar el funcionament de la capella i la seva importància en la vida catedralícia i de la ciutat, així com per a l'obtenció de dades concretes dels músics que hi treballaren.

\section{AGRAÏMENTS}

La present tesi va començar com un petit treball de curs que formava part de l'assignatura Música Romàntica, impartida pel Dr. Josep Maria Gregori a l'U.A.B., el curs 1991-1992.

El primer agraïment és per a ell, que va saber incitar en mi la passió i la il·lusió per la recerca musicològica, a més del savi guiatge proporcionat durant els anys esmerçats en la culminació d'aquest treball. També vull fer una menció especial a la seva esposa, la professora i musicòloga Meritxell Vinaixa, pel bonic tracte rebut.

L'acabament d'aquesta tesi no hauria estat possible sense la inestimable ajuda de moltes altres persones i entitats:

\footnotetext{
${ }^{2}$ Aquest músic compositor, fou mestre de capella laic de la catedral de Girona a partir de l'any 1850.
} 
El canonge arxiver i professor de la U.d.G Dr. Gabriel Roura, i a l'arxiver i historiador Joan Villar. Per l'amable acollida que he tingut $i$ les facilitats donades per a la recerca.

La Fundació Güell, doncs gràcies a la beca atorgada el curs 1994-95 vaig tenir la possibilitat de dedicar-me a aquest treball i immergir-me de ple en el fascinant món de la musicologia.

El Dr. en musicologia Jordi Rifé, per les orientacions inicials, que suposaren una important empenta a la realització d'aquest projecte.

El rector de la parròquia de St. Josep de Maó, el mossèn Dr. Josep Sastre, pels seus aclariments en les qüestions litúrgiques.

Un record molt especial dins aquestes línies, és per a la meva mare Montiel Arrué, per la gran ajuda, encoratjament i suport durant tot el temps que ha durat el present estudi. Aquest agraïment es fa també extensible al meu pare i germans, l'interès dels quals per l'estat del treball, i la seva possible fi, em feien refermar amb el compromís personal adquirit.

Finalment al meu marit Miquel Àngel Muñiz, tot i que sóc conscient que les paraules que pugui emprar en aquestes línies, mai no seran mai suficients per agrair-li tot el recolzament $\mathrm{i}$ els ànims rebuts durant la realització de la present tesi. 


\section{INTRODUCCIÓ}




\section{FONTS GENERALS}

La present recerca es basa en gran mesura en les fonts existents en l'Arxiu Capitular de la Catedral de Girona. Cal remarcar l'abundància i la importància dels documents trobats, que m'han permès realitzar un estudi exhaustiu $i$ en profunditat de la capella de música. De tota manera, no s'ha descartat la consulta d'altres arxius, per veure si podia complementar o confirmar algunes dades concretes d'interès per a la investigació.

\section{L'ARXIU CAPITULAR DE LA CATEDRAL DE GIRONA}

Les fonts del segle XIX no estan catalogades, pel que la seva localització ha estat lenta i complicada. Aconsellada pel Dr. Gregori, el primer pas fou buidar la informació musical existent en tots els llibres de Resolucions Capitulars, i després en els Llibres de Comptes de l'Obra. D'altres fonts en vaig tenir notícia a través de cites aparegudes en documents consultats, com és el cas de la Consueta de l'organista Antoni Guiu que apareixia citada en el llibre del mestre $\mathrm{Civil}^{3}$, i que no hi va haver forma de localitzar-la fins al final del període destinat a la recerca, quan va aparèixer entre els manuscrits musicals. En tot moment vaig tenir l'ajuda del Dr. Roura i l'arxiver Joan Villar, sobretot per la documentació referent a la comunitat de beneficiats.

\footnotetext{
3 CIVIL I CASTELLVÍ, Francesc. El fet musical a les comarques gironines en el lapse de temps 1800-1936. Girona: $2^{\mathrm{a}}$ edició, Dalmau Carles Pla, 1994, p. 15.
} 


\section{a) Llibres de Resolucions Capitulars}

Aquests llibres constitueixen un fidel, dens i voluminós testimoni de tot el que s'esdevenia a la Seu. Aproximadament un cop per setmana el capítol dels canonges, encapçalat pel bisbe es reunien a la sala capitular per a debatre i prendre totes aquelles decisions que afectaven als membres de la catedral. El capítol dels canonges era doncs, el principal organisme consultiu i executiu.

Els temes que es tractaven en aquestes sessions eren molt variats, car la Seu posseïa terres, béns immobles i un gran nombre de persones al seu càrrec. Pel que fa a la capella de música es prenien decisions referides a si calia o no contractar algun nou músic, i de quina forma, altres vegades es decidia si calia celebrar una determinada funció, també es debatia si s'havia comprar o arranjar algun instrument, els augments de sou, els permisos per a sortir de la catedral.... El secretari del capítol aixecava acta de tot el que es parlava en cada una d'aquestes reunions i de tot en quedava constància.

Els llibres consultats han estat els següents:

Resoluciones Capitulares de 28 de Septiembre de 1757 a 31 de Mayo de 1764.

Resoluciones Capitulares de 28 de Septiembre de 1764 a 31 de Mayo de 1772.

Resoluciones Capitulares de 28 de Septiembre de 1772 a 31 de Mayo de 1782.

Resoluciones Capitulares del 28 de Septiembre de 1782 al 31 de Mayo de 1786.

Resoluciones Capitulares del 1 de Junio de 1786 al 31 de Mayo de 1788.

Resoluciones Capitulares del 1 de Junio de 1788 al 31 de Mayo de 1791. 
Resoluciones Capitulares del 1 de Junio de 1786 al 31 de Mayo de 1791.

Resoluciones Capitulares del 1 de Junio de 1791 al 31 de Mayo de 1794.

Resoluciones Capitulares del 1 de Junio de 1794 al 31 de Mayo de 1797.

Resoluciones Capitulares del 5 de Diciembre de 1798 al 19 de Sept. de 1800.

Resoluciones Capitulares del 27 de Septiembre de 1800 al 13 de Mayo de 1803.

Resoluciones Capitulares del 2 de Junio de 1803 al 28 de Febrero de 1807.

Resoluciones Capitulares del 5 de Marzo de 1807 al 27 de Mayo de 1812.

Resoluciones Capitulares del 23 de Mayo de 1812 al 2 de Junio de 1815.

Resoluciones Capitulares del 1 de Junio de 1815 al 31 de Mayo del 1817.

Resoluciones Capitulares del 1 de Junio de 1817 al 31 de Mayo del 1819.

Resoluciones Capitulares del 4 de Junio de 1819 al 31 de Mayo del 1821.

Resoluciones Capitulares del 2 de Junio de 1821 al 31 de Mayo del 1823.

Resoluciones Capitulares del 6 de Junio de 1823 al 31 de Mayo del 1825.

Resoluciones Capitulares del 1 de Junio de 1825 al 31 de Mayo del 1827.

Resoluciones Capitulares del 1 de Junio de 1827 al 31 de Mayo del 1829.

Resoluciones Capitulares del 1 de Junio de 1829 al 31 de Mayo del 1831.

Resoluciones Capitulares del 1 de Junio de 1831 al 31 de Mayo del 1833.

Resoluciones Capitulares del 1 de Junio de 1833 al 31 de Mayo del 1835. 
Resoluciones Capitulares del 1 de Junio de 1835 al 31 de Mayo del 1837.

Resoluciones Capitulares del 2 de Junio de 1837 al 31 de Mayo del 1840.

Resoluciones Capitulares del 1 de Junio de 1840 al 31 de Mayo del 1843.

Resoluciones Capitulares del 1 de Junio de 1843 al 31 de Mayo del 1846.

Resoluciones Capitulares del 1 de Junio de 1846 al 31 de Mayo del 1849.

Resoluciones Capitulares del 1 de Junio de 1849 al 31 de Mayo del 1854.

\section{b) Llibres de Comptes de l'Obra}

En aquests 1libres apareixen les entrades i sortides de diners de l'Obra. Per exemple hi trobem anotats els diners que es gastaven en cera, els que es pagaven al sabater que arreglava les sabates dels escolans, els que es pagaven a les bugaderes i planxadores, etc. Aquests documents són molt interessants doncs en alguns llibres, sota el títol Despeses de la Capella, han aparegut llistats de músics, instrumentistes $\mathrm{i}$ cantors. Fins i tot en algun exemplar ha quedat constància de la funció que complia algun d'aquests personatges (tenor, xantre, violinista...) donant-nos valuoses pistes per a la recopilació del nom i el nombre de músics que formaven part de la capella.

Llibres de Comptes de l'Obra 1781-1783, inscrip. 3,a,4. Llibres de Comptes de l'Obra 1787-1789, " 5,a,10. Llibres de Comptes de l'Obra 1791-1795, " 21,b,3. Llibres de Comptes de l'Obra 1791-1800, " 21,b,2. Llibres de Comptes de l'Obra 1795-1800, " 21,b,4. Llibres de Comptes de l'Obra 1799-1801, " 21,b,9 Obra 1801, " 1,b,10 
Llibres de Comptes de l'Obra 1801-1805, " " 1,b,11

Llibres de Comptes de l'Obra 1806-1810, " "21,c,3

Llibres de Comptes de l'Obra 1809-1815, " 21,c,4

Llibres de Comptes de l'Obra 1815-1817, " 21,c,5

Culto 1821, " 21,c,12

Llibres de Comptes de l'Obra 1821-1828,

Llibres de Comptes de l'Obra 1822-1824, " " 21,c,14

Llibres de Comptes de l'Obra 1828-1830, sense inscripció

Llibres de Comptes de l'Obra 1831-1850, sense inscripció

\section{c) Llibre de Noms i Cognoms}

El títol que encapçala la coberta és Llibre dels Noms, y Cognoms dels Escolans del Cor, y Capella de musica de la Sta Isglesia de Gerona.

És un preciós llibre que es començà a escriure l'any 1708. On els mestres de capella que anaven passant per la Seu tenien l'obligació d'inscriure-hi els escolans de cor que tenien al seu càrrec, per al coneixement del capítol. Les dades que hi solien anotar eren el nom i els cognoms de cada escolà, el lloc de procedència i el dia que començaven a servir a la Seu, així com el dia que en sortien.

L'existència d'aquest 1libre, venia regulada pel punt quinzè de les Ordinacions de la Capella de Música de l'any $1735^{4}$. El fet que el llibre tingui una procedència més antiga, ens fa pensar que l'obligació d'inscriure els escolans podia venir regulada per unes ordinacions anteriors.

Tot i ser una font molt valuosa per la gran quantitat de dades que ens aporta, cal remarcar que hi ha un buit temporal. Durant cinc anys i per motius que desconeixem, els mestres de capella no utilitzaren aquest 1libre. Aquest buit va des de

\footnotetext{
${ }^{4}$ El tema de les ordinacions es tracta en profunditat en el capítol II.
} 
la mort del mestre de capella Rafael Compta el 1815, fins a l'entrada del mestre Jaume Joan Lleys el 1820.

\section{d) Correspondència capitular}

En les informacions aparegudes en les actes capitulars, moltes vegades es comenta l'existència cartes rebudes o enviades pels músics al capítol o a individus de la capella. Moltes de les cartes rebudes pel capítol, provenien de músics aspirants a obtenir una plaça $\mathrm{i}$ contenien documents interessants per a la present investigació, com currículum, cartes de recomanació, certificats de resultats obtinguts en oposicions i altres similars. És per aquest motiu que he revisat tota la correspondència existent a l'arxiu, datada en el període que comprèn els anys 1800-1850. Malauradament, tot i el gran nombre de documents llegits, pocs han estat els que guardaven una relació directa amb la capella de música i els seus integrants. Tampoc he trobat documents molt concrets, citats directament als llibres d'actes, la qual cosa ens fa pensar que molta d'aquesta documentació, per ser més personal, s'ha perdut.

\section{e) Llibres de la comunitat de beneficiats}

La comunitat de beneficiats era l'agrupació dels clergues que posseïen un benefici. Aquest benefici, entitat jurídica erigida a perpetuïtat, constava d'un ofici sagrat o eclesiàstic, $i$ comportava unes obligacions amb la comunitat així com el dret a percebre les rendes que s'havien estipulat al crear el benefici. Com que la major part dels integrants de la capella de música eren beneficiats, he consultat tots els llibres que pertanyen a aquesta comunitat, des de l'any 1800 fins al 1850 . 


\section{e.1. Possessions i obits 1746-1836}

Aquest 1libre forma part del gruix de llibres que pertanyen a la comunitat de beneficiats. En faig una menció especial, perquè la informació que aporta és important per a veure qui eren els clergues beneficiats que formaven part de la capella de música. En aquest volum hom enregistrava la data en què els membres de la catedral prenien possessió d'un benefici, el nom d'aquest benefici i la data de defunció del beneficiat ${ }^{5}$. Si considerem que gran part dels músics de la capella formaven part de la comunitat de beneficiats, la consulta d'aquest llibre esdevé imprescindible.

\section{f) Consueta de l'organista Antoni Guiu}

El títol exacte que apareix a la portada d'aquest llibre és Consueta per lo regimen del Organista de la Cathedral de Gerona. En aquest manuscrit l'organista Antoni Guiu va anar apuntant la tasca que havia de realitzar l'organista cada dia de l'any i el sou que havia de percebre. ${ }^{6}$

\footnotetext{
5 Tot i la importància cabdal d'aquest llibre, cal esmentar que la informació aportada és molt minsa pel que fa als òbits, doncs per causes que desconeixem, només hi ha enregistrats els compresos en el període 1748-1797, període que no contempla el present estudi.

${ }^{6}$ El mestre Francesc Civil en el seu llibre El fet musical a les comarques gironines..., Ob.cit, p. 15 i 16, diu que en aquesta consueta s'hi troben certes informacions referents a la Guerra del Francès. Després de llegir detalladament diverses vegades la consueta, no he trobat les dades citades; només hi ha una petita informació referent a la marxa dels francesos, el 1814 .
} 


\section{ALTRES ARXIUS CONSULTATS}

\section{a) L'Arxiu Parroquial de Sta. Maria del Pi de Barcelona}

En aquesta parròquia hi treballaren els mestres de capella Josep Barba ${ }^{7}$ i Joan Carreras Dagas, després d'haver estat mestres de capella de la catedral de Girona. En la documentació buidada, també apareixen altres integrants de la capella gironina, fet que demostra una important relació entre ambdues capelles.

S'han consultat les següents fonts documentals:

a.1. Determinacions de la Comunitat, anys 1834-1874.

a.2. Capsa I, $\mathrm{n}^{\circ}$ 141: història capella de música Sta. Maria del Pi.

a.3. Capsa II, $\mathrm{n}^{\circ}$ 142: història capella música Sta. Maria del $P i$.

\section{b) L'Arxiu Episcopal de Vic}

D'aquest arxiu s'han consultat diversos llibres de resolucions, perquè hi havia un contacte estret entre les capelles de Vic i Girona, com ho demostra l'intercanvi de músics que sovint es produïa. Un dels exemples és el del violinista Josep Quilmetas, que es formà i treballà a les dues capelles.

\footnotetext{
${ }^{7}$ Josep Barba es formà musicalment com a escolà de cor a la capella de música de Sta. Maria del Pi, lloc d'on mai perdé el contacte. Quan marxà de Girona, obtingué per oposició la plaça de mestre de capella a Sta. Maria del Mar, de la mateixa època s'han trobat documents signats per ell a Sta. Maria del Pi, com si en fos mestre auxiliar.
} 


\section{c) L'Hemeroteca de l'Arxiu Municipal de la Ciutat de Girona}

M'ha semblat interessant consultar la premsa publicada durant l'època objecte d'estudi, per a poder analitzar possibles relacions entre l'estament civil i l'eclesiàstic.

\section{c.1. Gaseta del Corregiment de Girona}

Noticiari publicat 1'any 1810. A 1'Arxiu Municipal hi hem consultat alguns números; la impressió és a foli i dues columnes, amb el text íntegrament en català.

\section{c.2. El Correo de Gerona}

Publicat a partir del cinc de febrer de l'any 1795, dos cops per setmana. És el segon periòdic gironí, després de la Gazeta de Gerona, bisetmanari, en quart (1787-1800) ${ }^{8}$

\section{c.3. Boletín Oficial de la Provincia}

Apareix a partir de l'any 1837, tres cops per setmana.

\section{c.4. El Postillón.}

Publicat diàriament a partir de l'any 1834, és on han aparegut més notícies d'interès per al present estudi. Aquest periòdic publicava regularment des del setembre de 1837 , les obres de teatre estrenades a Girona.

\footnotetext{
${ }^{8}$ RAHOLA, Carles. La Ciutat de Girona. Barcelona: Editorial Base, reedició 2000, Volum II, p. 35.
} 


\section{FONTS MUSICALS: PARTITURES}

\section{L'ARXIU CAPITULAR DE LA CATEDRAL DE GIRONA}

A l'Arxiu Capitular de la Catedral es conserven més de cinc-centes obres composades durant la primera meitat del segle XIX. En dues-centes vuitanta-una d'aquestes obres, hi figura el nom de l'autor. El volum restant, d'aproximadament unes tres-centes obres manuscrites anònimes, tenen datació $o$ altres clars indicis de pertànyer a l'època objecte estudi.

No hi ha una catalogació de les obres, el que sí hi ha és un fitxer alfabètic per autors, que reuneix tant les obres manuscrites com les impreses. En les fitxes hi ha la descripció del manuscrit amb nom i cognoms del compositor, data, mida, nombre de folis, i l'íncipit literari quan n'hi ha. En el capítol IV del present estudi he inclòs l'inventari de les obres manuscrites conservades, dels autors que formaren part $o$ tingueren relació directa amb la capella de música en els anys estudiats.

Un gran nombre d'obres conservades dels primers cinquanta anys del segle XIX, pertanyen al gènere litúrgic i religiós, només sis de les dues-centes vuitanta-una obres són de caire civil. D'aquestes sis, cinc són purament instrumentals, de les quals he transcrit el Tema con Variaciones para el Violoncello à toda Orquesta, del mestre Jaume Joan Lleys i la Yntroducción y Variaciones de Flauta, Piano y Fagote obligados, de l'organista Antoni Guiu. 


\section{ALTRES ARXIUS CONSULTATS}

\section{a) L'Arxiu Parroquial de Sta. Maria del Pi de Barcelona}

Com ja s'ha mencionat anteriorment, en la capella del Pi hi treballaren els mestres Josep Barba i Joan Carreras Dagas. A l'arxiu hom pot consultar l'Inventari provisional dels Fons Musicals realitzat pels musicòlegs Maria A. Ester Sala i Josep Maria Vilar i Torrents, revisat posteriorment per Lluís Borau i Barbó. De Josep Barba i Carreras Dagas es conserven un determinat nombre d'obres religioses. En aquest inventari consta que la Simfonia en Mi bemoll Major de 17989', del tenor de la capella gironina Bernat Bertran, que actualment es troba en la Biblioteca de Catalunya, es trobava inicialment a l'arxiu del Pi.

\section{b) L'Arxiu de l'Orfeó Català}

S'ha consultat per a descartar tota possibilitat de que hi hagués alguna composició interessant per al present estudi. Cal dir que no disposa de cap obra pertanyent als músics que formaren part de la capella de la catedral de Girona.

\section{c) L'Arxiu Històric de la Biblioteca de Catalunya: secció de manuscrits}

Aquest arxiu s'ha consultat perquè Joan Carreras Dagas, gironí i mestre de capella de la catedral de Girona a partir de l'any 1850 , va recollir un conjunt de llibres i manuscrits, la majoria provinents de la catedral gironina, recopilats en el fons musical "Carreras Dagas". Aquest fons, fou més tard

\footnotetext{
${ }^{9}$ BERTRAN, Bernat, Simfonia en Mi bemoll Major, 1798. Estudi i edició a càrrec de Francesc Bonastre. Barcelona: Biblioteca de Catalunya, 1991, p. XL-XLI.
} 
adquirit per la Diputació de Barcelona per a dur-los a la Biblioteca de Catalunya.

D'aquest fons documental s'han transcrit les Quatre Sonates d'Albert ${ }^{10}$ (Miquel) contrabaixista de la capella de música de la Seu gironina, datades 1'any 1800. La Sinfonia obligada de organo, para violines, viola, flauto, clarinetes, corni, organo y basso ${ }^{11}$, d'Antoni Guiu, organista de la catedral gironina durant més de trenta anys. També s'hi troba la Sinfonia $1^{a}{ }^{12} \mathrm{de}$ Carles Quilmetas, primer violí, músic laic de la capella de música de la catedral, i pare del violinista Josep Quilmetas, que està estudiada i transcrita pel Dr. J. M ${ }^{a}$ Vilar $^{13}$. Finalment, també s'han consultat els tractats pedagògics de Jaume Joan Lleys, mestre de capella de la catedral de Girona, i més tard de la capella de música de Castelló d'Empúries ${ }^{14} \mathrm{i}$ de Francesc Andreví ${ }^{15}$, que tot $\mathrm{i}$ no treballar a Girona, sí que fou professor de molts dels músics que hi passaren.

\footnotetext{
${ }^{10} \mathrm{~N}^{\mathrm{o}}$ de manuscrit $388 / 2$.

${ }^{11} \mathrm{~N}^{\mathrm{o}}$ de manuscrit $692 / 10$

${ }^{12} \mathrm{~N}^{\mathrm{o}}$ de manuscrit $692 / 11$

${ }^{13}$ Segons el propi musicòleg, aquest treball no està encara publicat.

${ }^{14} \mathrm{~N}^{\mathrm{o}}$ de manuscrit 125,245 i 124.

${ }^{15} \mathrm{~N}^{\mathrm{o}}$ de manuscrit 494.
} 


\section{ESTAT DE LA QÜESTIÓ}

\section{BIBLIOGRAFIA CRÍTICA}

a) El fet musical a les comarques gironines en el lapse de temps 1800-1936

No hi ha cap estudi que tracti globalment la capella de música de la catedral gironina al segle XIX. Tot i que sí hi ha importants treballs musicològics que aporten dades de coneixement d'alguns dels músics que formaren part de la capella. Aquest és el cas dels estudis del mestre Francesc Civil i Castellví, musicòleg, organista, compositor i professor de música, personatge de gran rellevància dins l'àmbit cultural gironí. ${ }^{16}$ A ell li devem diversos articless ${ }^{17}$, essent l'aportació més destacada el llibre El fet musical a les comarques gironines en el lapse de temps 1800-1936 ${ }^{18}$. En els treballs musicològics del mestre Civil, però, les informacions estan molt barrejades i abarquen molts temes al mateix temps.

Tot seguit, presento un buidat dels personatges que surten en el llibre de Francesc Civil, i que foren membres de la capella de música entre l'any 1800 i el 1850. He copiat textualment les entrades de cada individu, posant la informació entre cometes, indicant la pàgina del llibre on surt cada informació; cal dir que hi ha pàgines numerades amb números àrabs $\mathrm{i}$ també en romans ${ }^{19}$, i que moltes vegades un

${ }^{16}$ CERVERA i BERTA, Josep Maria. Biografia del mestre Francesc Civil i Castellví. Girona: Conservatori Isaac Albèniz de Girona, 1992.

${ }^{17}$ Per als estudis publicats pel mestre Civil, vegi's la Bibliografia.

18 CIVIL I CASTELLVÍ, Francesc. El fet musical a les comarques gironines en el lapse de temps 1800-1936. Girona: $2^{\mathrm{a}}$ edició, Dalmau Carles Pla, 1994.

${ }^{19}$ El llibre té un apartat amb numeració romana. 
mateix personatge surt citat en diferents parts del llibre. He fet un comentari a peu de plana, quan la informació aportada pel mestre Civil no es correspon amb les dades obtingudes a través de la meva recerca.

Albert, Miquel : "músic de la Seu (compositor), vivia al Pont Major. Edat 33 anys." P. XVI (citant la relació de músics del padró de Girona 1808)."Al llindar del segle XIX, en 1804, precisament, la Capella de Música de la Catedral estava integrada segons "Registre de Pagos" de l'Arxiu Cap. per: [...] Miquel Albert, laic (2: De Miquel Albert, Arxiu de la Catedral de Girona, 7 obras: Responsoris; Motets; Missa a 8 veus, etc..., anys 1786-1790)"

Albertí, Marià ${ }^{20}$ : "Oposità a la plaça d'organista de la Catedral de Girona, tenia 43 anys d'edat. Guanyà el càrrec l'organista de Sanahuja, el Rev. Antoni Guiu (Act. Cap. 23 de novembre 1804)" p. 121.

August, Romuald"21 “músic de la Seu.” p. XVI (citant la relació de músics del padró de Girona 1808).

Barba, Josep: "Poc després, el jove Joan Lleys, [...], llavors, Mestre de Capella de la Parroquial, una Catedral feta, de Castelló d'Empúries terra d'on procedia de part materna. Acabava de marxar-ne, clergue encara, en Josep Barba, que passà a ocupar el Mestratge vacant de la Seu gironina. Gairebé podia suposar-se un tàcit acord entre ambdós personatges." p.21

${ }^{20}$ El nom correcte, és Marià Albert i no Albertí. La data de l'acta capitular és correcta.

${ }^{21}$ En tots els documents consultats no apareix mai un Romuald August; sí que apareix en canvi un Romuald Huguet, instrumentista de flauta, fagot i oboè entre 1803 i 1817. 
"El nou Mestre de Capella, barceloní, nat en 1804 i clergue encara, Josep Barba, procedia en aquell moment, com se sap, de Castelló d'Empúries. La seva estada a Girona repercutí molt favorablement en el nivell i ambient artístic i musical de la Ciutat tant en el terreny religiós com en el profà i fins teatral; no reparà en collaborar amb els compositors ciutadans, en majoria deixebles seus, animant-los constantment. I: De Claudi Girbal, referent als orígens del Teatre Principal a Girona. “... al mismo (Rev. J. Barba) se debió el que Gerona contara en plazo relativamente corto con orquesta y cantantes, debiendo para ello empezar por aprender los rudimentos de toda la instrumentación que al efecto necesitaba, y logrado esto, dirigióse a la juventud entusiasta, escogiendo a los que reconoció con mejores aptitudes musicales, y en breve los resultados correspondieron a los esfuerzos del genio que dio cima a empresa tan difícil. Una vez que Gerona contaba con núcleo suficiente de artistas músicos, las autoridades y principales familias propusiéronse fundar un teatro de ópera italiana, gracias a la oportuna cooperación del Mtro. Barba, a quién pensaron confiar la dirección, pero este rehusó tal (p. 24) cargo por estar en oposición con su estado sacerdotal y sentimientos religiosos. No desistieron sin embargo, los iniciadores de tal pensamiento y acudieron al diocesano para obtener el permiso necesario. El diocesano que conocía las dotes morales del dignísimo y ejemplar sacerdote, le rogó autorizándolo, para que aceptara la dirección artística del teatro. Acordado, vióse obligado a aceptar, fundándose el teatro de ópera italiana y bajo la dirección del digno maestro, y contando con sus discípulos, se pusieron en escena la Semiramide, la Saffo, Barbero, Norma, Lucía, Hernani, etc.etc." "Hago constar, empero, añade el biógrafo, que a pesar de correr la dirección artística a su cargo, ni una sola vez concurrió al espectáculo" (Revista de Girona, març de 1893) 
"Deixà en l'arxiu de la Capella abundor d'obres d'aquest (p. 23) seu període gironí, producció que en certa proporció prengué el camí de la Bibl. Central de Barcelona com la de tants altres Mestre de per ací. A poc de la seva arribada a Girona li sortí per anar a ocupar la plaça de Mestre de Valladolid, però el Capítol gironí, a fi de retenir-lo li augmentà la retribució en cent rals fins que fós ordenat. També posteriorment li foren ofertes vàries altres vacants, car era tot un talent, si bé les anava descartant per no haver de deixar als seus pares que junt amb ell vivien. Morts, i prèvies oposicions, guanyà i ocupà, en $1846^{22}$, la plaça de Sta. Maria del Mar, de Barcelona, que guardà fins al seu traspàs, en 1881 ”. p. 24

"El mestre Carreras Dagas, fill de Girona, 1828, deixeble estat tot primer de Anton Vidal, l'organista de la Col-legial de Sant Feliu; seguidament ho fou del Mtre. Barba". p.25.

"La successió de'n Carreras Dagas a la Catedral fou confiada al Beneficiat organista del moment, el Rev. Bernat Papel1 $^{23}$ (1821-1877) Els primers estudis musicals els realitzà amb el seu oncle Joan Carreras i Prats, organista de l'església del Carme [...]. Quant al nebot, Mn. Bernat Papell i Carreras aficionat a la composició, rebé profitoses lliçons del Mestre Barba i seguidament, en $1841^{24}$, se n'anà a França, ...” p.27.

"En 1880, dirigia la Capella de Música parroquial de Figueres el rev. Domènec Murtra, fill de girona i deixeble

\footnotetext{
${ }^{22}$ La renúncia formal de la plaça de mestre de capella de la catedral de Girona és, segons els llibres capitulars, del 19 de desembre de 1850.

${ }^{23}$ Organista de la capella de música des de 1838 fins a 1842.

${ }^{24}$ Segons les actes capitulars, la renúncia formal de la plaça és del tres de març de 1842, per anar a una catedral francesa.
} 
estat, de minyó, del Mtre. Josep Barba, a l'escolania de la Catedral, a partir de $1835 .{ }^{25,}$ p. 61.

Bassas, Ramon: "La darrera manifestació que li coneixem (referent a Rafael Compta) correspon al Veredicte per ell autoritzat, com a únic examinador, per l'abril de 1815, a favor d'un opositor, solitari igualment, Ramon Bassas, de Vic, com així mateix el propi Mestre, i en que manifesta: "en fagot y flauta ha cumplido bien y es hàbil, que en el óboe no es tan aventajado pero en todo se complementa." Ço que ve a demostrar com els membres d'aquelles Capelles de Cant, tots, qui més qui menys simultaneijarien el domini de diversos instruments." p. 18.

Bert, Josep" ${ }^{26}$ : "Bons tractes i millor ensenyament es devia de rebrer a Girona quan des de La Bisbal hi acudien escolars gaire bé, per famílies, com aquests altres [...]. Podem completar aquesta relació amb els noms de Joan Vicens; Josep Bert, Ramon Serra i Joaquim Pons. Tots aquests minyons, de retorn a la llar ja estarien suficientment instruïts musicalment $\mathrm{i}$ sabrien de tocar algun que altre instrument com per a integrarse en cobles comarcals o per opositar a diversos mestratges, com en el cas del Mtre. Pons.” p. 70.

Bertran, Bernat : "Al llindar del segle XIX, en 1804, precisament, la Capella de Música de la Catedral estava integrada, segons "Registre de Pagos" de l'Arxiu Cap. per: Rafael Compta, Mestre de Capella; [...] Bernat Bertran, prev. 3: De Bernat Bertran, (Arxiu de la Catedral de Girona) Rosari, a 4 veus i orquestra." p. 14.

"Les oposicions per a cobrir la baixa del Rev. Organista Josep Prat tingueren lloc el 23 de novembre de 1804.

\footnotetext{
${ }^{25}$ Consta que Domènec Murtra fou escolà de cor entre els anys 1824 i 1830 .

${ }^{26}$ Escolà del cor de la catedral entre 1797 i 1804.
} 
Formaven el tribunal els Revs. Rafael Compta, Mtre. De Capella, Bernat Bertran, beneficiat de la mateixa i Miquel Massip, organista del Monestir de sant Daniel, "extramuros" de Girona." p.15.

Bisbe, Fidel: "Bons tractes i millor ensenyament es devia de rebrer a Girona quan des de La Bisbal hi acudien escolars gaire bé, per famílies, com aquests altres [...] i el desventurat Manel Bisbe, que morí anegat en el riu Ter, del temps del Mtre Pons. Dos germanets més ocuparen el seu lloc, Josep i Fidel; aquest últim, precisament, escolà vers $1796^{27}$, fou qui estrenà l'orgue de Cassà de la Selva, instaurat l'any 1805." p. 70.

Josep Pujol el 1805 reforma l'orgue de Sant Fèlix. "El seu primer titular fou el Rnt. Fidel Bisbe, fill de La Bisbal, que de minyó havia pertenescut a la Capella de Cant de la Catedral, del temps del Mestratge del Rnt. Rafael Compta”. p.89

Blanch, Tomas: "Al 1lindar del segle XIX, en 1804, precisament, la Capella de Música de la Catedral estava integrada, segons "Registre de Pagos" de l'Arxiu Cap. per: Rafael Compta, Mestre de Capella; [...] Thomàs Blanch, laic, conduït per a tocar la trompa." p.14

"Més endavant, a 31 de gener del 1807, ja veiem com el mateix músic (Pere Hilla) sol-licita augment de salari per haver d'encarregar-se del paper de $1^{\text {a }}$ trompa y demés instruments que en Thomàs Blanch, per la seva edat $\mathrm{i}$ xacres no podia més assegurar. Aquest últim perteneixia a la Capella, de trompa, des de, al menys, 1767, al desconduir-se de la Catedral la Cobla dita de Banyoles; un altre dels seus components, en Joan Mirambell, restà també en nòmina a partir de 1767. El pobre Thomàs Blanch ja finava, el dia 5 de

${ }^{27}$ Escolà entre 1796 i 1802. 
març següent, de 1807 , d'un atac d'apoplèxia, ${ }^{28}$ havent-se ofert per a sustituir-lo, de $2^{\mathrm{a}}$ trompa un germà precisament de l'esmentat Pere Hilla" p.15

Buxó, Esteve : "Al llindar del segle XIX, en 1804, precisament, la Capella de Música de la Catedral estava integrada, segons "Registre de Pagos" de l'Arxiu Cap. per: Rafael Compta, Mestre de Capella; [...] Esteve Buxó, subdiaca $^{29} . "$ p. 14.

Carreras Dagas, Joan: "Degut a les especials circumstàncies d'aquella època el Benefici anexe al Mestratge de Capella fou suprimit $i$ entrant el servei de la mateixa anà acàrrec del ja conegut rev. Francesc Crehuet, tot primer, a la vegada tenor de la Catedral, de 1846 a 1851. Li succeí, de 1851 a 1860 en Joan Carreras Dagas, seglar, i a aquest últim el Rev. Bernat Papell; a la vegada també d'organista, de 1860 a 1864." p.24

"Ignorem cap pormenor del primer dels anteriors mestres, Mn. Crehuet, no així del mestre Carreras Dagas, fill de Girona, 1828, deixeble estat tot primer de Anton Vidal, l'organista de la col-legial de Sant Feliu; seguidament ho fou del Mtre. Barba. De molt jove, devia tenir uns 23 anys, ja fundava, il·lusionat, a Girona un "Establiment Musical" o sia una "Escola de Música", anticipi, a cent anys, del Conservatori actual. En tal ocasió va publicar un manifestprograma d'estudis amb noms novells llavos com: Rodolph, pel Solfeig; Czerny, Vigerie, Kalbrenner i Cramer, pel piano, i Joaquim de Viniés i Espinola, per l'Armonia, Contrapunt i Composició. La Matrícula d'entrada era de 80 rals, i 30 de mensual; es comprometia, la Direcció, de prevenir els pares donat cas de poca capacitat per part de l'alumne. Es projectava

\footnotetext{
${ }^{28}$ La data de la notícia de l'atac d'apoplexia en el llibre d'actes, és correcta, traspassà el vint-i-vuit d'abril de 1807.

${ }^{29}$ Esteve Buixó era contralt de la capella, fins al 1814.
} 
així mateix en el manifest l'organització mensualment d'una audició vocal i instrumental a càrrec de l'alumnat. Desconeixem més detalls sobre tants bons propòsits $\mathrm{i}$ l'eficàcia i temps que durà l'Escola."

"Durant el seu estatge al front de la Capella de Música de la Catedral se'l convidà a compondre l'Ofici complert, en gregorià, de la preciosa Sang de N.S.J.C. 1libre cantoral que es conserva i va firmat de l'autor a 10 de maig de 1852. Deixà igualment escrites bon nombre de composicions religioses per a la Capella, entre elles una Missa amb orquestra, encarregada, qui sap, per l'Ajuntament de Girona, ja que resta guardada, la partitura, ben enquadernada, en l'Arxiu Municipal, juntament amb un solemne Himne que avui sembla que s'hagi perdut. Es prodigà també en compondre obres de circumstància i de saló, per a veus o per a instruments, sovint premiades en Concursos a la Península i a l'estranger. També es dedicà a l'escriptura operística: a 18 anys ja va estrenar i dirigir personalment, a Girona, "Il Renegato", seguit de "Rosamunda en Ravena", obra aquesta estrenada, sembla, a Madrid. Musicòleg i col·leccionista reuní una important selecció d'instruments i així mateix de vells manuscrits originals del mestres gironins del XVII i del XVIII, que més endavant, adquirits mitjançant compra per la Diputació de Barcelona, foren dictaminats $\mathrm{i}$ catalogats pels Mestres Pedrell i Francesc Pujol. Bibl. Centr. $\mathrm{Ja}$, en 1870 , de tota aquesta riquesa documental i de nombroses altres peces de vàlua en Joan Carreras va publicarne un Catàleg, citant, per a la majoria, la procedència, no així, inexplicablement de les de Girona, i això fou de lamentar."

"En 1860 es traslladà a Barcelona, membre, un temps, de l'orquestra del Liceo, ensenyà Música a 1'Escola de Cecs, residí a França, i finalment es retirà a La Bisbal on aconseguí 
de formar molts bons deixebles." p.25 "Morí en aquesta important població empordanesa l'any 1900."30

Carreras Vilardell, Joan:"Entretant, a Girona la curta interinitat fou confiada al Beneficiat de Cant, Rev. Josep Quilmetas que com a tal Mestre, el 19 de juliol de $1822^{31}$ redactà la següent Certificació "Habiendo examinado a los dos muchachos pretendientes del empleo de Escolar de Coro que està vacante, manifiesta a V.S. que los dos son habiles en leer pero en solfa y voz sobrepuja Juan Carreras Vilardell, escolar de la sacristía de los RR. Beneficiados.” p.21

“Aquest Carreras (Joan Carreras Vilardell), gironí i ben dotat musicalment bé podria ésser el pare o pròxim familiar del notable compositor i musicòleg Joan Carreras i Dagas del que tindrem àmplia oportunitat de parlar més endavant." p. 21

Casanovas, Manuel: (Referent a Banyoles) "Posteriorment es torna a parlar d'un orgue, monumental aquesta vegada, que fou contractat al preu de 1900 Lliures Francesc Roura, instrument ubicat damunt la tercera capella del temple, entrant a mà esquerra. Al llindar del s. XIX ocupaba l'orgue el Rev. Manuel Casanovas, que participà, als $34{ }^{32}$ anys d'edat, a les oposicions celebrades en 1804 per a proveir el càrrec similar a la Catedral de Girona i que es donà al Rev. Antoni Guiu, com ja és sabut. Li succeí, fins a la dispersió de la Comunitat, en Joaquim Ramió” p. 122.

Compta, Rafael: "En març de 1794 entrà en funcions el nou Mtre. Rafael Compta (sots-mestre de la Catedral de Barcelona) després de provada fortuna a València, Valladolid i

\footnotetext{
${ }^{30}$ Informació que apareix en les p. 26-27-28-31-32-33-69-71-72-73-7677-78-81-83-93-104-122-123-124 i 133, del 1libre de Francesc Civil, Ob.cit.

${ }^{31}$ Escolà del cor entre 1822 i 1826.

${ }^{32} \mathrm{~A}$ les actes capitulars, apareix que tenia 33 anys.
} 
a Sta. Maria del Pi, de Barcelona. En realitat havia aconseguit el primer lloc en les oposicions un seu germà, Antoni Compta, Mtre.de Cap. De Sta. Maria del Mar, si bé a lúltim moment hi renuncià pretextant que "no se reconeixia amb qualitats suficients per a merèixer tan singular benefici". El Capítol no insistí per considerar que hi haurien raons de família pel mig, nombrant seguidament a en Rafael, sobradament conegut, havent participat en anteriors oposicions, les d'en Pons. Natural de Vic, el nou Mtre. Simultaniejà tot primer les seves tasques amb els estudis de telolgia i una vegada ordenat, demanà 1licència d'uns dies, 16 de juliol de 1797, per anar a cantar la Primera Missa vora els seus familiars."p.14

"Les oposicions per a cobrir la baixa del Rev. Organista Josep Prat tingueren lloc el 23 de novembre de 1804. Foermaven el tribunal els Rev. Rafael Compta, Mestre de Capella, Bernat Bertran, beneficiat de la mateixa i Miquel Massip, organista del Monestir de Sant Daniel "extramuros" de Girona. (aquestes oposicions les guanyaria Antoni Guiu)" p. 15

"Amb la retirada de les tropes franceses els cors s'obren de nou a l'esperança. Ferran VII participa, el 2 de març de 1814, la seva arribada a Girona per l'endemà de que assistiria al Te Deum a la Catedral; el Capítol disposa en conseqüència "que los músicos cantaren la Misa como se acostumbra a hacer en esta Iglesia en las dominicas de Pasión, que es a voces y con instrumentos baxos (o sia de corda) en el coro alto" i per tant, sense orgue. Es de suposar que per la circumstància s'estrenaria el Te Deum, a 8 veus, dos cors i orquestra, compost exprofés pel mestre Rafael Compta, obra que es conserva encara en l'arxiu de la Catedral." p.17

“Tornant a Rafael Compta, el Mtre. De Capella de la Catedral, la seva producció, molt extensa, Misses a 4 i 5 veus, amb orquestra, Lamentacions i tota una gama d'obres 
religioses de circumstància, hi compès l'esmentat Te Deum, sembla, avui, repartida entre 1'Arxiu catedralici i la Bibl. Central. [...] La darrera manifetació que li coneixem correspon al Veredicte per ell autoritzat, com a únic examinador, per l'abril de 1815, a favor d'un opositor, solitari igualment, Ramon Bassas de Vic [...]. De retorn a la seva terra, l'esmentat Ramon Bassas, finalitzats els exercicis d'oposició, després de comunicar al Capítol l'haver ja rebut la clerical tonsura, s'excusa de la demora en incorporar-se a les seves obligacions, pel fet de què, al moment d'empendre el camí per a Girona, que comptava realitzar-lo en companyia del Mtre. Compta, de repòs uns dies prop dels seus, li sobrevingué a aquest últim una indisposició que l'obligà a restar. Tal fet esdevenia el 2 de juliol de 1815, i el 5 d'agost següent se'ns informa ja que "habiendo fallecido el Maestro de Capilla, era menester buscar uno que cuidase de los muchachos de coro... nadie mas apto para el desempeño de este cargo que el actual organista (A. Guiu) [...]. El dia 9 següent (de setembre) tingueren lloc enterrament i funerals." p.18

Crehuet, Francesc: Feia les substitucions del mestre Guiu, quant aquest anava a Sant Joan de les Abadesses. p.22

"Degut a les especials circumstàncies d'aquella època el Benefici anexe al Mestratge de la Capella fou suprimit i entratant el servei de la mateixa anà a càrrec del ja conegut Rev. Francesc Crehuet, (I: La capacitat artística del Rnt. Francesc Crehuet queda de manifest per l'existència d'unes obres compostes seves en l'arxiu de la Catedral de Girona, entre: Solos; Duos; Motets i Rosaris, a 4 veus i orquestra; Responsoris; a Sant Narcís i a la B.M.V., a 6 i a 8 veus ; etc. La índole de les quals sembla demostrar que exerciria també el càrrec de Mtre. de Capella de la Col·legiata de Sant Feliu, com a successor d'Antoni Vidal) tot primer, a la vegada tenor de la Catedral, de 1846 a 1852 . Li succé́, de 1851 a 1860 en Joan Carreras Dagas, seglar [...]" P. 24 
Dorda i Llorens, Baltasar: "La provisió de la vacant d'organista pel pas del Rev. Guiu a una canongia a la Col-legiata de Sant Feliu resultà igualment quelcom laboriosa. Es presentaren dos opositors: el Rev. Vicens Paradell, organista de Sabadell i el Rev. Baltasar Dorda, organista de Mataró. L'acta corresponent manifesta que "en atención a la escasez de buenos profesores de órgano, aúnque parecía que a los dos opositores aprobados les faltaba alguna circunstancia, se procedió a la votación y resultó electo para organista el pbro. D. Baltasar Dorda, con todos los votos excepto uno". Es possesionà del càrrec el $12 \mathrm{~d}$ 'agost de 1829."p.23

"Havia estat alumne de Francisco Andreví exercint a Girona per poc temps i passant a Mataró de mestre de capella, lloc d'on era fill. És autor d'un "stabat" i d'un "requiem". Mort en olor de santedat el 1839, havia disposat que tota la seva producció fos cremada i per això no se'n conserva res. (Mitjana pag. 2267).” p. II

Ferré Arquimbau, Domènec: "Per aquells mateixos anys figura entre els beneficiats cantors de la capella un tal Domingo Ferrer Arquimbau, també de Torroella, i certament familiar del precedent (DomingoArquimbau) ${ }^{33}$, el mateix que fou temporalment sollicitat per a tocar l'orgue en el ja esmentat convent de Benedictines de Sant Daniel." p.12

"Al llindar del segle XIX, en 1804, precisament, la Capella de Música de la Catedral estava integrada, segons "Registre de Pagos" de 1'Arxiu Cap. Per: Rafael Compta, Mestre de Capella, [...] Domènec Ferré Arquimbau, clergue" p.14

\footnotetext{
${ }^{33}$ Era el seu nebot, a la capella l'anomenaven Dominguet. Fou tenor de la capella entre els anys 1797-1818. En aquesta data marxà a Sevilla, on el seu oncle n'era el mestre de capella.
} 
"Durant els Sitis de 1808-1809 diversos membres d'aquesta Capella de Música, com Antoni Guiu, Josep Quilmetas, Narcís Pibern, Miquel Policarp i Domènec Ferrer entre altres contribuiren a la defensa comú de la Ciutat allistant-se a la $8^{\text {a }}$ Cia. De voluntaris" p. 15

Freixeda, Narcis 34: "Al 1lindar del segle XIX, en 1804, precisament, la Capella de Música de la Catedral estava integrada, segons "Registre de Pagos" de l'Arxiu Cap. Per: Rafael Compta, Mestre de Capella, [...] Jacint Freixeda, prev." p.14

Gomis, Ramon : "clergue de 25 anys obtenia un segon lloc en oposicions per a la vacant d'organista de Girona, l'any 1804".p.9

Guiu, Antoni : "En 1773 vingué al món a Sant Joan de les Abadesses el futur organista de la Catedral de Girona, Antoni Guiu [...]. Vegi's aquí no obstant l'acta baptismal: 'En esta Parroquial Iglesia de Sant Joan y Sant Pau de les Abadessas, Bisbat de Vich, als vint y tres de Mars de mil setcents setanta y tres, fonch batejat per lo Dr. Joan Cibat pvre. y Sagristà de dita Iglesia, Antoni, Jeroni, Joseph, nat en lo mateix dia de dit mes y any, fill llegítim y natural de Joseph Guiu, sabater, y de Rosa Roquer, conjuges. Foren padrins antoni Roquer, Brasser y Gracia Guiu, viuda deixada de Esteve Guiu, perayre, tots de la present Vila i Parroquia'. "Solia el mestre Guiu, venir cada any a aquesta seva terra per a gaudir de l'escalf familiar $\mathrm{o}$, de salut precària, segons ell, 'per a prendre-hi els aires i les aigües de la Muntanya (Acta Cap 1er d'agost 1820 i altres). De retorn se'n devia endur algun minyó per a la seva Capella de la Catedrali aprendre-hi música; tals, en Ramon Solà nat a Sant Joan de les Abadesses

${ }^{34}$ Com escriu més tard el mateix Civil, el nom correcte és Jacint i no Narcís, fou contralt de la capella entre 1795 i 1810. 
en 1812 i en Pere Masdeu ${ }^{35}$, en 1813; ambdós eren uns noiets de vuit anys quan varen ingressar a la Capella de Girona, en 1820 i 1821 respectivament, segons consta en el llibre de Noms i Cognoms...” p. 100.

"En 1787 Sta. Maria de Ripoll tingué com a organista, nombrat en propietat, a un minyó de tot just catorze anys, Antoni Guiu, de Sant Joan de les Abadesses; de més gran ja exerciria el mateix càrrec a Sanahuja i en 1804, després d'unes oposicions, per cert, ben renyides, obtindria l'orgue de la Seu de Girona." p. 107.

"El mestre Guiu no degué ésser l'únic de la Capella de música que sofrís dels rigors d'un supost desterrament cap a les terres de Sant Joan de les Abadesses i possiblement exili a França; ens assabenta, en efecte una Acta Capitular de 14 de Juny de $1882^{36}$ : "Se leyó un memorial del subdiácono Jayme Virosta, sochantre de esta Iglesia, participando al Cabildo su ausencia por un año en San Juan de las Abadesas por orden del Gobierno...". Dies després per nota de 18 de juny, sabem que la consignació de l'organista quedava reduïda a 2 rals diaris, per manca de fondos en les arques capitulars" Addenda $n^{0} 2$, p. 129.

Hilla, Pere: "Al llindar del segle XIX, en 1804, precisament, la Capella de Música de la Catedral estava integrada, segons "Registre de Pagos" de l'Arxiu Cap. Per:

35 Es deia Joan Pau Masdeu, i no Pere. Formà part de l'escolania el 1821, abans que el capítol despatxés els quatre escolans de cor, a resultes del Trienni Constitucional.

${ }^{36}$ Evidentment, hi ha un error en aquesta data en referència a Jaume Virosta, i així ho indica el mestre Civil a la $2^{\mathrm{a}}$ Addenda de la segona edició del llibre El fet musical ,Ob. Cit.: "On diu 14 de juny de 1882 ha de dir 1822" p. XIV. Pel que fa a l'organista Antoni Guiu en l'acta de 28 de juny de 1822, demana una llicència per motius de salut, marxarà a França i no tornarà fins el febrer de 1824 . 
Rafael Compta, Mestre de Capella, [...] Pere Hilla, laic músic de trompa." p.14

"El susdit Pere Hilla ja s'havia ofert abans, en 1796, per a tocar a la Capella sens salari, l'óboe, la flauta i la trompa fins que resultés vacant el Benefici corresponent, i així mateix demanava que li deixéssin tocar els ministrils en els Viàtics, i la part que li toqués en els actes en que intervinguéssin trompes. Més endavant, a 31 de gener del 1807, ja veiem com el mateix músic sol-licita augment de salari per haver d'encarregar-se del paper de $1^{\text {a }}$ trompa y demés instruments que en Thomàs Blanch, per la seva edat $i$ xacres, no podia més assegurar" p. 15

Huguet, Romuald: “Al llindar del segle XIX, en 1804, precisament, la Capella de Música de la Catedral estava integrada, segons "Registre de Pagos" de l'Arxiu Cap. Per: Rafael Compta, Mestre de Capella, [...] Romuald Huguet, laic" p.14

Juncà i Carol, Francesc : "de Sabadell, 1742, procedent de 1'Escolania montserratina, que de Sub-Mtre. De la Cap.de Cant de Sta. Maria del Mar de Barcelona, guanyà per oposició, clergue encara, la successió del Mestre Gònima a la Catedral gironina el 1774. Més tard fou nombrat a igual càrrec en la Catedral de Toledo, fins que en $1792 \mathrm{i}$ per disposició reial retornà a la Seu de Girona però ja amb càrrec capitular. Canonge i Comissari a la Música deixà de banda la composició i emprengué, entre altres activitats la tasca d'ordonar i de restaurar els llibres corals de Cant. De totes maneres aquells primers set anys de mestratge de la Capella de Música foren fructífers: unes 60 obres entre motets, salves, oratoris, un Rèquiem a 8 veus i orgue, una Nona a vuit veus igualment amb violins, xerimies, sacabuixs, pifres i demés orquestra, Te Deum, etc., el tot, existent en l'arxiu de Girona. La Nona de referència deuria ésser de curta duració, si en 
creiem la següent anotació de l'organista Atoni Guiu pvre. en la seva consueta: "Ascensió 1805. El psalm ab orgue de la nona dèu acabar se a dos quarts $y$ sinch minuts per la una poch més poc menos si canten la Nona de Juncá que és més curta" p.11

Lleys, Jaume Joan: "en los regocijos que la Inmortal Gerona celebró la feliz terminación de la guerra civil carlista, los días 19, 20 y 21 de mayo de 1876, se cantó en la iglesia de san Félix, la Misa de Requiem a 4 voces, del reputado Maestro Lleys de la villa de Castelló de Ampúrias, la misma que se ejcutaba todos los años en el aniversario de los que murieron durante los gloriosos Sitios de la Ciudad en 1808-9." p.IV

En Jaume Joan Lleys va "publicar un "Tratado de Armonía y composición Musical" obra tècnica decididament oberta a les noves tendències en l'escriuptura; Convencido, ens diu, de la inutulidad del sistema de enseñar la composición musical seguido en España, quise proporcionarme algunos de los enseñados en los principales conservatorios de Europa, incluyendo en este número al último publicado por el Sr. D. Francisco Andreví: De todos he formado el que presento al público, extractando de cada uno lo que me ha parecido màs útil, etc..."p. 49.

"Projectava en Lleys, continuar aquest seu estudi mitjançant una segona part que no assolí de publicar però que es conserva manuscrita en la susdita Bibl. Central:" Tratado teórico y Práctico de la imitación libre y Canónica". Respecte del qual afegeix Pedrell: “...aquesta obra revela en Lleys la idea de donar a llum lo llibre de la imitació lliure i canònica, qual exemplificació procedeix d'ell mateix, molta part del mestre Andreví, de Richter, de Cherubini, etc. I això suposa en aquella època un mestre de veritable ilustració" 1: ... "Psalmo 2 thono a 8 siendo mi maestro el Rdo Francisco Andreví, 
Maestro de Capilla de Santa Maria del Mar de Barcelona, año 1818" Lleys devia tenir llavors uns 16 o 17 anys" p. 50.

Massip, Miquel: "organista del Monestir de San Daniel "extramuros" Formà part del tribunal en les oposicions d'organista a la Catedral de Girona d'Antoni Guiu, el 23 de novembre de 1804. p.15 "Les oposicions per a cobrir la baixa del Rev. Organista Josep Prat tingueren lloc el 23 de novembre de 1804. Formaven el tribunal els Revs. Rafael Compta, Mtre. De Capella, Bernat Bertran, beneficiat de la mateixa i Miquel Massip, organista del Monstir de sant Daniel, "extramuros" de Girona." p.15

Ortis, Francesc : "Francisco Hotis (sic) músic de la Seu (compositor), plaça de les Cols, 38 anys." p. XVI (citant la relació de músics del padró de Girona 1808)

Pagés, Francesc: "Al llindar del segle XIX, en 1804, precisament, la Capella de Música de la Catedral estava integrada, segons "Registre de Pagos" de l'Arxiu Cap. Per: Rafael Compta, Mestre de Capella, [...] Francesc Pagés, prev." p.14

Papell, Bernat: "Bernat Papell, figuerenc" p.II. "Mossèn Bernat Papell, organista de Girona, Besiers i Nimes. Guanyà oposicions i no les aprofità. Morí el 8 d'abril de 1926, als 90 anys."p. VI. "La successió de'n Carreras Dagas a la Catedral fou confiada al Beneficiat organista del moment, el Rev. Bernat Papell (1821-1877) Els primers estudis musicals els realitzà amb el seu oncle Joan Carreras i Prats, organista de l'església del Carme [...]. Quant al nebot, Mn. Bernat Papell i Carreras aficionat a la composició, rebé profitoses lliçons del Mestre Barba i seguidament, en 1841, sen'anà a França, d'organista a la parròquia de Sant Lluís, de Béziers i després a la catedral de Nimes. Concorregué a les oposicions per als càrrecs d'organista i Mtre. De Capella, units, que guanyà, a 
Girona, de 1860 a 1864 . De retorn a França, morí a Sète a 31 març de 1877, als 60 anys d'edat. Els contemporanis el consideraven una autoritat en el domini de la Música, haventse publicat i tot, en edició pòstuma una seva "Missa Solemne" a tota orquestra. Resten d'ell: Missa per a orgue i cant. Salve per a tible i orgue, composta de quan era Mtre. De Capella a Girona; Vals per a Música militar (1841) reduït a piano a 4 mans; Sonata per a piano (1869); Polonesa i Rondó brillant a 4 mans (1870). Sense ésser gran erudit dominava totalment l'art de la Música, molt il·lustrat, afable i senzill de tracte doblat de sacerdot humil i caritatiu. (Rev de Girona)" p.27

Paradell, Vicens: "La provisió de la vacant d'organista pel pas del Rev. Guiu a una canongia a la Col-legiata de Sant Feliu resultà igualment quelcom laboriosa. Es presentaren dos opositors: el Rev. Vicens Paradell, organista de Sabadell i el Rev. Baltasar Dorda, organista de Mataró. L'acta corresponent manifesta que "en atención a la escasez de buenos profesores de órgano, aúnque parecía que a los dos opositores aprobados les faltaba alguna circunstancia, se procedió a la votación y resultó electo para organista el pbro. D. Baltasar Dorda, con todos los votos excepto uno". Es possesionà del càrrec el 12 d'agost de 1829."p.23

Pibern, Narcis" : "Al llindar del segle XIX, en 1804, precisament, la Capella de Música de la Catedral estava integrada, segons "Registre de Pagos" de l'Arxiu Cap. Per: Rafael Compta, Mestre de Capella, [...] Narcís Pibern, prev. Músic d'òboe, flauta, fagot i trompa." p.14

Policarp, Miquel: “Al llindar del segle XIX, en 1804, precisament, la Capella de Música de la Catedral estava integrada, segons "Registre de Pagos" de l'Arxiu Cap. Per:

${ }^{37}$ El nom que consta a les actes és Narcís Bibern o Vivern, beneficiat d'instruments de vent $\mathrm{i}$ alfuller de la capella de música durant el període comprès entre 1795 i 1816 . 
Rafael Compta, Mestre de Capella, [...] Miquel Policarp, prev. violinista" p.14

"Durant els Sitis de 1808-1809 diversos membres d'aquesta Capella de Música, com Antoni Guiu, Josep Quilmetas, Narcís Pibern, Miquel Policarp i Domènec Ferrer entre altres contribuiren a la defensa comú de la Ciutat allistant-se a la $8^{\text {a }}$ Cia. De voluntaris" p. 15

Portell, Antoni: “Antoni Portell de 41 anys, organista o ¿orguener? ${ }^{38}$, vivia al Portal de la Barca, segons padró d'habitants del 1847, fol. 315" p. IV

Prat, Josep: org. CdG, 1785 ; "aquest últim s'allargà fins a principis del s.XIX; morí circumstancialment a Barcelona 1'any 1804" p.9.

Quilmetas, Carles $^{39}$ : músic de la Seu (compositor), carrer de la Força, 52 anys.” p. XVI (citant la relació de músics del padró de Girona 1808)

Quilmetas, Josep: "Al llindar del segle XIX, en 1804, precisament, la Capella de Música de la Catedral estava integrada, segons "Registre de Pagos" de l'Arxiu Cap. Per: Rafael Compta, Mestre de Capella, [...] Josep Quilmetas, clergue, músic de violí i trompa (I: Arxiu de la Catedral de Girona- Gozos a Sant Sixt i a Sant Tou, a 4 veus, amb instruments.- Magníficat, a 4 veus i oequestra.)" p.14

"Durant els Sitis de 1808-1809 diversos membres d'aquesta Capella de Música, com Antoni Guiu, Josep Quilmetas, Narcís Pibern, Miquel Policarp i Domènec Ferrer

\footnotetext{
${ }^{38}$ Era un orguener mallorquí, realitzà un pressupost l'any 1845, per arreglar l'orgue major.

${ }^{39}$ Aquest Carles era pare de Josep Quilmetas, provenien de Vic.
} 
entre altres contribuiren a la defensa comú de la Ciutat allistant-se a la $8^{\text {a }}$ Cia. De voluntaris" p.15

En les oposicions del 9 de novembre del 1819 per a cobrir la vacant de contralt, veiem a Antoni Guiu, Antoni Santamaria i Josep Quilmetas com a tribunal. p.19

El nou de gener del 1822, el mestre Jaume-Joan Lleys marxa de la Catedral de Girona per anar a Castelló d'Empúries. "Entretant, a Girona, la curta interinitat fou confiada al Beneficiat de Cant, Rev. Josep Quilmetas" p. 21

Santamaria, Anton: "Al llindar del segle XIX, en 1804, precisament, la Capella de Música de la Catedral estava integrada, segons "Registre de Pagos" de l'Arxiu Cap. Per: Rafael Compta, Mestre de Capella, [...] Anton Santamaria, subdiaca, fagotista i flautista. ${ }^{, 40}$ p.14

"En les oposicions del 9 de novembre del 1819 per a cobrir la vacant de contralt, veiem a Antoni Guiu, Antoni Santamaria i Josep Quilmetas com a tribunal”. p.19

Serrat, Josep: "Al 1lindar del segle XIX, en 1804, precisament, la Capella de Música de la Catedral estava integrada, segons "Registre de Pagos" de l'Arxiu Cap. Per: Rafael Compta, Mestre de Capella, [...] Josep Serrat, prevere" p.14

"la següent nota del Llibre de Resolucions Capitulars de la Catedral de Girona de desembre de 1745/fol. 224 ens dóna una idea de l'importància que devia revestir la Capella de Música de Torroella en aquelles dates (Uns Capitolars varen exposar que) "lo Rd. Josep Serrat, altre dels conduits (contractats) en dita Capella ab salari de 3011 havent-se oposat a la vacant de un Benefici de Torroella fonch de ell proveit, $i$

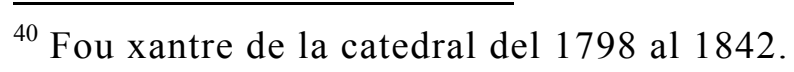


com sia ja ordenat de Diaca se troba instat de part de la vila de Torroella perque vagia a residir son Benefici: que segons la Relació que ha fet lo Mtre. de Capella, (de Girona) si lo dit Serrat va a Torroella fora molta falta pués no tindrá la Capella qui toqués lo Aubue, y altres Instruments de Música, que en atenció a assó havent tractat amb dit Serrat ofereix quedarse en dita Capella y renunciar dit Benefici (títol ab el qual es ordenat) ab tal que V.S. li assenyal o aumente lo salari fins a una cóngrua suficient a computa de... "Resolució: fiat.” p. 75

Verdaguer, Honorat: Reverend Honorat Verdaguer, mestre de capella el 1817 a la Catedral de Girona. Confraria de l'Esperança. p.I

Vidal, Antoni: Nascut a Camprodon, "que de minyó figurà d'escolar en la Capella de cant de la Catedral de Girona , de 1801 a 1805, i que més endavant, al terme dels seus estudis eclesiàstics, esdevingué, en 1818, Mtre. de Capella i organista de la Col-legial de Sant Feliu. [...] Es de pensar que durant la manifesta i llarga crisi en el mestratge de la Capella de la Catedral de Girona, consegüent a l'ocupació francesa, fins a la presa de possessió del Mtre. Josep Barba, seria el Rev. Vidal qui ostentaria la màxima autoritat en l'àmbit filharmònic ciutadà, car efectivament son varis, entre ells Carreras Dagas i en Vila. [...] Es conserven algunes composicions en la Bibl. Cent. De Barcelona: "Rosari a quatre veus, en català, amb violins, flautes i baix"; "O vos omnes" a tres veus, pertaneixent a l'any 1819; una peça a quatre i a cinc veus i orgue "Para dar luz inmortal" (A la Concepción) i "Gozos a tres, con violines, a San Francisco de Asís" de l'any 1823, i "Oh Coro Celestial", a quatre i vuit veus amb orquestra, Arxiu Catedral de Girona." p.104

Vila Firat, Narcís: “Titular fins a l'exclaustració ( de l'orgue de Besalú) un jove anomenat Narcís Vila Firat, de nacionalitat, casualment, francesa, nascut a Girona, l'any 
1812, quan l'ocupació; havia sigut deixeble del mestre de capella de la Col-legiata de Sant Feliu, el susdit Antoni Vidal, de l'organista de la Catedral Antoni Guiu i també, a última hora del recent nombrat Mestre, Josep Barba. L'orgue dels Benedictins li serví d'escambell per anar-se formant, quan en 1835 hagué d'integrar-se al seu país on tot seguit ocupà l'orgue de la Catedral de Narbona. Com a compositor havia obtingut un primer Premi en Certamen celebrat a Tolosa. Posteriorment obtingué d'ocupar la de Saint Gaudens, on morí als 65 anys, en 1877. (Revista de Girona. Juny de 1877)." p.119

\section{b) El órgano y los organistas de la catedral de Gerona durante los siglos $\mathrm{XIV}-\mathrm{XVI}^{4 I}$}

Cito aquest article del mestre Civil, per que entra en una contradicció en parlar dels orgues de la catedral. En el citat article afirma l'existència de tres orgues a la catedral gironina, a mitjan s.XVI, sense mencionar el portàtil.

"A mediados del s.XVI la Catedral gerundense contaba, pues, con tres órganos, a saber: $\mathrm{I}^{\circ}$, el más pequeño, emplazado en los claustros, o quizás en la capilla de Nuestra Señora de la Esperanza, contigua a la puerta de entrada a los mismos; tratábase de un pequeño instrumento que hemos visto, aunque sin pulsarlo, en la pequeña tribuna de dicha capilla y que en 1936 fue destruido, o mejor dicho, dispersados sus restos. $2^{\circ}$ Un órgano mediano, que acababa de reconstruir el maestro Pierre Bordons, teniendo como base el instrumento que antes había fabricado Juan Ferrando y que se halla emplazado en lo alto de la capilla de San Juan, al lado meridional del templo.

${ }^{41}$ CIVIL CASTELLVÍ, Francesc. "El órgano y los organistas de la catedral de Gerona durante los siglos XIV-XVI", Anuario Musical, IX, (1954), p.217-233. 
$3^{\circ}$ Un órgano mayor, que según creemos estaria colocado sobre el coro como el presente." ${ }^{42}$

En canvi en el llibre "El fet musical a les comarques gironines..." diu que l'any 1800 a la seu hi havia tres orgues: l'orgue gran, el de la capella de l'Esperança, i a més el portàtil. Deixant de mencionar 1'orgue petit o de semidobles, que estava situat a la paret meridional de la catedral, i que segons 1'article anterior fou reconstruit per l'orguener Bordons, el s. XVI. Amb les seves paraules:

"La ciutat comptava, en 1800 , amb les següents orgues en els seus diversos temples: A la Catedral. Orgue monumental, l'orígen i l'existència del qual es perden més enllà del segle XIV. Un altre instrument, mitjà, a la Capella de 1 'Esperança, a l'entrada del claustre, i que hem aconseguit de veure, si bé totalment inservible; ja no existeix. Més un tercer orguenet, portàtil ; del Llibre de pagos any 1803: Se paga per portar lo Orgue Petit i Manxador en la Nit de Nadal, 8 sous. Tampoc existeix avuí."

La veritat és que el 1800 a la catedral hi havia quatre orgues: el major, el de semidobles, el de la capella de l'Esperança i el portàtil. ${ }^{44}$ Com es comprova amb la suma dels dos textos, el mestre Civil coneixia l'existència dels quatre orgues, però amb el manejament de tanta informació com abarca, sembla ser que se'n descuida.

\footnotetext{
${ }^{42}$ Idem, p. 227 i 228.

${ }^{43}$ CIVIL CASTELLVÍ, Francesc. El fet musical..., p. 47.

${ }^{44}$ Vegi's en el capítol II, "Els recursos instrumentals i materials de la capella", la secció dels orgues.
} 
c) Diccionario biográfico-bibliográfico de efemérides de músicos españoles

En segon lloc, cal mencionar el llibre de Baltasar Saldoni Diccionario biográfico-bibliográfico de efemérides de músicos españoles, asi profesores como aficionados ${ }^{45}$. On apareixen diverses referències biogràfiques de músics de la catedral gironina.

"Efemérides, en las que consta el nacimiento ó falleci-/miento, ó ambas cosas á la vez, en cada dia del año, de uno/ ó varios profesores ó aficionados: En esta sección figuran/ 530 nombres" (contraportada final):

D. Baltasar Dorda: " 6 de Enero de 1802. Nace en Mataró (Cataluña) el presbítero D. Baltasar Dorda y Lloberas, distinguido organista." p. 24. "Muere en Mataró el presbítero y acreditado organista, el 15 de noviembre de 1839." p.101.

D. Mateo Ferrer: "conocido por Mateuét, maestro compositor y organista de la Catedral de dicha ciudad. Nace en Barcelona el 25 de febrero de 1788." p.36.

D. Ramon Aleix: "El 1 de Marzo de 1850. Muere en Barcelona el maestro de Capilla de la parroquial iglesia de Santa Maria del Mar, presbítero ----, autor de varias obras de música sagrada." p.38

D. José Barba: "15 de abril de 1804, nace en Barcelona --- presbítero y maestro de Capilla en la iglesia parroquial de Santa Maria del Mar de aquella capital” p. 51

45 SALDONI, Baltasar. Diccionario biográfico-bibliográfico de efemérides de músicos españoles. Madrid: Imprenta Pérez Dubrull, 1868-1881, 3 vols. 
D. Lluis Vallllovera ${ }^{46}$ : Muere en Barcelona el dia 21 de junio de 1853, mientras tocaba el órgano, en la Misa Mayor y siendo el dia de su santo, el presbítero ---, organista de la parroquial iglesia de Santa Maria del Mar. (p. 67)

D. Ramon Parcerisa: Muere en Oviedo el 26 de julio de 1859, el tenor de la santa iglesia catedral, D. ---, profesor muy distinguido y estimado, y una de las mejores voces que se habían oído en aquella suntuosa basílica" p. 74

D. Francisco Juncá y Carol: Nace en Sabadell, obispado de Barcelona, el 28 de Noviembre de 1742, el presbítero ---, maestro de Capilla que había sido de la catedral de Toledo.(p.104). Falleció siendo canónigo de la catedral de Gerona, el 19 de junio de 1833, á la edad avanzada de 91 años ( p.66)

" $2^{\mathrm{a}}$ Catálogo, ó lista por órden alfabético de todos los pro/fesores y aficionados mas conocidos, pasados y presentes,/ cuyo dia de nacimiento ó defunción no ha sido posible hasta/ ahora averiguar. En esta lista aparecen 1033 nombres, con/ datos curiosos acerca del mérito de cada cual, como compo/sitor, instrumentista ó cantante" (contraportada final)

Arquimbau, D. Domingo: "maestro de la catedral de Sevi-/lla por los años de 1823, habiendolo sido antes de la de Gerona: una sola composición suya presentada á la/ Academia filarmónica de Bolonia le valió la borla de doctor en música" (p.138)

Balius y Vila, D. Jaime: "Fue sucesivamente maestro de Capilla de las catedrales de Gerona y de Córdoba y/ del monasterio de monjas de la Encarnación de Madrid:/ autor de escelentes obras sagradas, entre las que des-/cuella sus

\footnotetext{
${ }^{46}$ En les actes capitulars surt com a Lluís Vallosera; fou aspirant a la plaça d'organista que l'any 1804 obtingué Antoni Guiu.
} 
celebres Lamentaciones del Jueves Santo, con orquesta: creemos que su mejor composicion sea el/ himno Deus tuorum militum, que escribió para las oposi-/ciones al magisterio de Córdoba." (p.140)

Compta, D...: "maestro de la catedral de Gerona, que fa-/lleció en Vich hácia el año 1814.” p. 158.

Guiu, D. Antonio: "organista muy acreditado, que falleció/ de canónigo en la colegiata de San Feliu de Gerona por/ los años de 1836: era natural de san Juan de las Aba/desas (Cataluña). ." p. 176.

Lleis, D...: "maestro de la catedral de Gerona por los/ años de 1820; desde aquí pasó á Castellon de Ampu-/rias, en dónde murió hácia 1851. El sucesor de Lleis/ en el magisterio de Gerona lo fue el presbítero D. José/ Barba./" p. 184.

Papell, presbítero D. Bernardo ${ }^{47}$ : “organista en Gerona; pasó/ a la catedral de Nimes (Francia), y hoy ha vuelto á/ Gerona". p.199.

Paradell, presbítero D. Vicente ${ }^{48}$ : organista de la colegial/ iglesia de Santa Ana de Barcelona. ”p. 199.

Pelegrín, D. Baltasar ${ }^{49}$ : natural de Gerona y organista en/ la espresada ciudad, desde donde pasó á Buenos-Aires/" p. 199.

47 Organista de la catedral entre 1838 i 1842, successor de Pelegrí Baltasar.

${ }^{48}$ Organista provinent de Sabadell, es presentà juntament amb Baltasar Dorda per a cobrir la plaça que havia deixat vacant l'organista Antoni Guiu. La plaça l'obtindria, el 1829, Baltasar Dorda.

${ }^{49}$ Organista de la catedral de Girona, entre 1833 i 1838, successor de l'organista Baltasar Dorda. 
Roura, presbítero D....: ${ }^{\mathbf{5 0}}$ estuvo de contralto en varias/ capillas, y ultimamente en 1859 desempeñaba el ma-/gisterio de Capilla en la catedral de Burdeos.” p. 211.

Verdaguer, D...: ${ }^{51}$ maestro de Capilla de la catedral de/ Génova, y posteriormente de Tortosa, en donde falleció/ á principios del siglo IX”.p.228.

\section{d) Cien músicos célebres españoles}

En el llibre Cien músicos célebres españoles ${ }^{52}$ hi ha un interessant estudi dedicat al mestre Josep Barba, que reprodueixo a continuació.

José Barba y Bendal (1804-1881): Fue uno de los mas destacados maestros de capilla del siglo XIX. Nacido en Barcelona el 6 de abril de 1804, ingresó de niño en la escolanía de la parroquial de Nuestra Señora del Pino, donde siguió con brillantez sus estudios. Distinguióse como organista, cuando apenas contava dieciocho años de edad, y concurrió al seminario para el estudio de la carrera eclesiástica.

El año 1825 celebró su primera misa y se presentó a oposiciones para maestro de capilla de la Catedral de Gerona, tomando posesion del cargo el dia 6 de agosto del citado año.

\footnotetext{
${ }^{50}$ Francesc Roura, fou contralt de la capella de música de la catedral, durant el període que va de 1819 a 1825 .

51 Aquest fragment està ple d'errors d'impremta, doncs Honorat Verdaguer, fou mestre de capella a la catedral de Girona entre 1816 i 1819.

52 MIRÓ BACHS, Antoni. Cien músicos célebres españoles. Barcelona: Ave, col. Mozart, 1955.
} 
El estudio de la música se hallaba tan abandonado en la capital gerundense, que las más de las veces tenía que suprimirse ésta en los divinpos Oficios, por falta de cantores y ejecutantes; mas no por eso se arredró el maestro Barba y dióse con todo entusiasmo al estudio de diveros instrumentos, para él, a su vez, enseñarlos alos jóvenes que creía más capacitados. Gracias a esto realizó el milagro de que en un espacio de tiempo relativamente corto, contase Gerona con una muy notable masa coral-orquestal para celebrar dignamente las funciones del culto.

El entusiasmo por la música fue en aumento en la capital y llegó un dia en que las familias más distinguidas, con el apoyo del Ayuntamiento, concibieron el proyecto de instalar en Gerona un teatro de ópera italiana.l Confiaron su dirección al presbítero José Barba quien, previas las licencias del obispo de la diócesis, llevó a feliz término la idea. Encargado de la dirección general, improvisó artistas y coristas y puso en escena, entre otras, las óperas Hernani, Norma, Lucía de Lamermoor y El Barbero de Sevilla.

Por puro pasatiempo, dedicábase el maestro Barba al "deporte" de concurrir a las oposiciones de maestro de capilla, y así ganó en noble lid las capellanías de Ampurias, Valladolid, Sevilla y Toledo, sin que tomase posesión de ninguna de ellas.

En el año 1850 presentóse a oposición para el Ma/gisterio de la parroquia de Santa María del Mar, de Barcelona, una de las más importantes de la capital, y tomó posesión del cargo, que desempeñó hasta su muerte, ocurrida el tres de febrero del año 1881 .

Como compositor, rayaba a gran altura, destacando de su inmensa producción religiosa, el Oratorio a Santo Tomás 
de Aquino y una Misa Pastoril, que alcanzó gran popularidad." 53

\section{e) Gran Enciclopèdia de la Música}

En el marc dels estudis actuals, cal remarcar la important contribució al panorama musical català que representa la Gran Enciclopèdia de la Música; en els set volums qua hi ha publicats actualment, hi podem trobar entrades dels mestres gironins Rafael Compta, Jaume Joan Lleys i Agramont, Josep Barba i Bendad i Joan Carreras i Dagas. També hi ha informacions dels organistes, que foren de la catedral, Antoni Guiu i Roquer i Bernat Papell i Carreras. I del tenor Bernat Bertran.

Bertran i Sastre, Bernat (Barcelona 1774, Mataró 1815). "Compositor català. Fou escolà de la catedral de Barcelona i possiblement rebé la seva primera formació del mestre de capella Francesc Queralt i de l'organista Carles Baguer. El 1796 ocupà la plaça de tenor a la capella musical de la seu de Girona ${ }^{54}$. El 1797 intentà obtenir, sense èxit una plaça de mestre de música a Castelló d'Empúries, i el 1799 fou ordenat de prevere. E1 1803 es presentà al càrrec de tenor de la Catedral de Barcelona, que no aconseguí. Entre 1808 i 1814 visqué la guerra del Francès i el setge de Girona. El 1814 esdevingué beneficiat del monestir de Sant Pere de les Püelles de Barcelona. Es conserven vuit obres, entre salms, responsoris, rosaris, una simfonia i un minuet, que es poden trobar a la Biblioteca de Catalunya, l'Arxiu de la catedral de Girona i l'Arxiu de la seu de Manresa. Cal destacar la Simfonia en mi b. Major (1798), l'estètica de la qual vira vers

\footnotetext{
${ }^{53}$ MIRÓ BACHS, Antoni. Cien músicos célebres españoles,Ob. cit. p. 67 i 68 .

${ }^{54}$ Fou tenor, per oposició, de la catedral de Girona entre 1796 i 1815.
} 
les influències germàniques, com ara F.J.Haydn. S'hi palesen a més, trets de l'estil galant $i$, en menor proporció de l'empfindsamkeit i del Sturm un Drang". ${ }^{55}$

Compta, Rafael (Vic?-Girona 1815). "Compositor català. Segons el seu propi testimoni, feu oposicions amb èxit, a les places de mestre de capella de la catedral de Valladolid i de l'església parroquial de Santa Maria del Pi de Barcelona, i també fou sotsmestre de capella de la seu barcelonina. E1 disset de març de 1794 ingressà, com a mestre de capella, i en substitució de Josep Pons, a la catedral de Girona, càrrec que conservà fins al seu òbit. L'arxiu d'aquesta catedral conserva nombroses obres d'aquest compositor vigatà. Compta utilitzà, en bona part de la seva producció, una plantilla instrumental constituïda per corda i vent amb reforç del contrabaix. Aquesta paleta tímbricà palesà ja l'estètica de la darreria de la divuitena centúria, concomitant de la d'aquell moment arreu d'Europa." 56

Carreras i Dagas, Joan (Girona 1828- La Bisbal d'Empordà 1900) "Compositor i pedagog català. Es formà a la capella de música de la catedral de Girona, i amb l'organista de l'església col·legial de Sant Feliu, Anton Vidal. De jove fundà una escola de música a Girona i, del 1851 al 1860, exercí de mestre de capella a la catedral de la ciutat. Posteriorment s'establí a Barcelona, on fou membre de l'orquestra del Liceu i professor de música a l'escola de cecs i en una de sordmuts. En aquelles dates havia començat a aplegar una important biblioteca musical a partir de l'adquisició de diferents impresos i manuscrits, i també una notable col-lecció d'istruments musicals. En la seva estada a Barcelona, aquesta gran biblioteca ja havia adquirit una fama

\footnotetext{
${ }^{55}$ RIFÉ SANTALÓ, Jordi. "Bertran i Sastre, Bernat". Gran Enciclopèdia de la Música, Barcelona: Fundació Enciclopèdia Catalana, 1999, vol. 1.

${ }^{56}$ RIFÉ I SANTALÓ, Jordi. "Compta, Rafael”. Gran Enciclopèdia de la Música. Barcelona: Fundació Enciclopèdia Catalana ,2000, vol. 2.
} 
considerable. El 1872 s'establí de nou a Girona, on fund una escola de música que deixà al cap de poc per anar a França, on s'estigué cinc anys. De retorn a Catalunya, fixà la seva residència a la Bisbal d'Empordà, on exercí de mestre de capella i d'organista, i també desenvolupà una important tasca docent. Compongué una abundant producció de tipus religiós, i algunes de les seves obres foren guardonades en diferents concursos. Aquesta producció es troba repartida entre l'arxiu de música de la catedral de Girona, l'arxiu municipal de Girona i la Biblioteca de Catalunya. També composà dues òperes, Il Renegato i Rosamunda di Ravena, un oratori i força repertori de saló. Sobre el seu important arxiu musical planaren diferents ofertes d'adquisició, i després d'informes tècnics de F.A.Barbieri i de M.Rodríguez d'Alcàntara, fou adquirit finalment per la Diputació de Barcelona. Aquest ha estat l'important fons fundacional de la Secció de Música de la Biblioteca de Catalunya, que fou catalogat per Felip Pedrell i editat amb el títol de Catàlech de la Biblioteca Musical de la Diputació de Barcelona (1909)". ${ }^{57}$

Barba i Bendad, Josep (Barcelona 1804-1881). "Compositor, organista i mestre de capella català. Inicià els estudis musicals a l'església de Santa Maria del Pi, on era escolà. Obtingué per oposició la plaça de mestre de capella en algunes poblacions com ara Girona, quan encara no era sacerdot, i més tard a Valladolid. El 1850 guanyà la mateixa plaça a Santa Maria del Mar, on romangué fins a la seva mort. Compongué un gran nombre d'obres religioses [...] . Deixà inacabat un estudi sobre el cant gregorià i les obres clàssiques hispàniques i el Tratado metódico práctico de composició". ${ }^{58}$

57 CORTÈS I MIR, Francesc. "Carreras i Dagas, Joan". Gran Enciclopèdia de la Música. Barcelona: Fundació Enciclopèdia Catalana, 2000, vol. 2.

${ }^{58}$ LÓPEZ LÓPEZ, Begoña. "Barba i Bendad, Josep". Gran Enciclopèdia de la Música. Barcelona: Fundació Enciclopèdia Catalana, 1999, vol. 1. 
Dorda i Lloberes, Baltasar (Mataró 1802-1839). "Compositor i organista català. Inicià els estudis musicals com a escolà al cor de la parròquia de Santa Maria de la seva ciutat. Ordenat de sacerdot el 1826, ocupà el càrrec d'organista a Mataró, i més tard, a la catedral de Girona. La seva fama com a instrumentista i protector dels més pobres féu que la catedral de Girona s'omplís de gent, desitjosa de veure al personatge quasi místic. Preocupat per aquesta situació, Dorda tornà a Mataró i proseguí la tasca d'organista, compositor i professor. Malgrat la seva facilitat per a escriure música i l'èxit de les seves obres, ordenà el seu pare que, després de la seva mort, cremés les composicions. De tot aques corpus compositiu només resten algunes referències, com ara la de les dues misses de Glòria, de rèquiem, un Stabat Mater i nombrosos motets, lamentacions i salms." 59

Guiu i Roquer, Antoni (Sant Joan de les Abadesses 1773- Girona 1836). "Organista i compositor català. A només tretze anys obtingué la plaça d'organista a Ripoll. Després va estar-se a Sanahuja i feu d'organista a la catedral de Girona des del 1804, en substitució de Josep Prat. A Girona, Guiu visqué els anys més difícils de la guerra del Francès i recollí en una consueta els esdeveniments més destacats d'aquells anys de penúries ${ }^{60}$. S'exilià a Nimes, i més endavant retornà a Girona, on el 1828 rebé una canongia a la col-legial de Sant

59 LÓPEZ LÓPEZ, Begoña. "Dorda i Lloberes, Baltasar”. Gran Enciclopèdia de la Música. Barcelona: Fundació Enciclopèdia Catalana, 2000, vol. 2.

${ }^{60}$ La consueta de l'organista Antoni Guiu, no recull les penúries de la guerra del Francès, parla estrictament de les intervencions de l'orgue en el calendari eclesiàstic, dia a dia. Només hi ha un petit comentari en el fol. 10, que reprodueixo a continuació Avuy dia 10 Mars de 1814 abandonaren esta Ciutat/ los Francesos sens causar dany als avitans, entregaren las Guar-/dias a la Tropa Española, y se retiraren al Castell de Figueras./ Pochs dias despues entrà lo Rey Fernando $7^{\circ}$ en esta Ciutat, y/ en seguida batuts los Francesos, y pres lo Nicolau Napoleon finil la Guerra. Al arribar a Madrid lo Rey Fernando quedà morta la Consti-/tució Española./ 
Feliu i hi ocupà el càrrec d'organista fins a la seva mort. Les fonts indiquen que mantingué sempre contactes amb Sant Joan de les Abadesses, d'on portà diferents escolans de la catedral de Girona. Entre les seves composicions destaquen un oratori al Beato Nicolás Longobardo (1807), del qual parlà molt bé R. Mitjana, una simfonia amb obligat d'orgue i obres religioses." 61

Lleys i Agramont, Jaume Joan (Figueres 1802Castelló d'Empúries 1851). "Mestre de capella català. Descendent de menestrals, a la seva família hi havia també altres músics actius a les comarques gironines. Estudià música a Barcelona, i el 1820 obtingué el mestratge de la catedral de Girona, on romangué només dos anys. El motiu de la seva marxa de Girona no fou només la permuta amb J. Barba, com apunta F. Civil. Segons els estudis de M. Galdon, l'estat de migradesa de la seu gironina en el període liberal i la manca de recursos de la capella feren que Lleys abandonés el seu càrrec per cercar un lloc millor. De Girona passà a Castelló d'Empúries, on la plaça, molt ben considerada en aquell moment, era vacant per la marxa de Josep Barba. Publicà un ineteressant Tratado de Armonía y composición Musical. De les seves obres a la catedral de Girona, se'n conserven de tipus religiós i també alguna de profana. Fou mestre de B. Frigola, N.Fita, J. Lleys i A. Juncà." 62

Papell i Carreras, Bernat (Figueres 1821-Seta, Llenguadoc 1877). "Compositor i organista català. Estudià música amb Joan Carreras i Prats a l'església del Carme de Girona i també rebé alguna lliçó de J.Barba. Exiliat a França

${ }^{61}$ CORTÈS I MIR, Francesc. “ Guiu i Roquer, Antoni”. Gran Enciclopèdia de la Música. Barcelona: Fundació Enciclopèdia Catalana, 2001, vol. 4.

${ }^{62}$ CORTÈS I MIR, Francesc. “ Lleys i Agramont, Jaume Joan”. Gran Enciclopèdia de la Música. Barcelona: Fundació Enciclopèdia Catalana, 2001, vol. 5. 
des del 1841, sembla que fou organista a Besiers, i més tard, a la catedral de Nimes. Retornà a Girona vers el 1860, on fou organista de la catedral per oposició i també mestre de capella en substitució de J. Carreras i Dagas, i posteriorment fou ordenat de prevere. L'estat bastant precari de la capella de música devia ésser el motiu pel qual abandonà ambdós càrrecs el 1864. Retornà a França i s'establí a Seta. Compongué una gran Missa, editada pòstumament, altres obres religioses i també obres de saló. Els seus contemporanis el tenien en gran consideració com a compositor i pels seus coneixements teòrics. La seva Missa Solemne li fou publicada pòstumament." 63

\section{f) Història de la Música Catalana, Valenciana i Balear.}

El volum III d'aquesta obra és dedicat al segle XIX, Del Romanticisme al Nacionalisme. En l'apartat La música religiosa ${ }^{64}$ es parla sobre la catedral de Girona, fent servir com a fonts les investigacions inicials del present estudi. S'hi comenta el nombre d'integrants i els mestres de capella que en formaren part ${ }^{65}$. A més s'hi exposa una relació de músics amb obres conservades a l'arxiu de la catedral gironina, $i$ es comenten resumidament els principals esdeveniments

63 CORTÉS I MIR, Francesc. "Papell i Carreras, Bernat". Gran Enciclopèdia de la Música. Barcelona: Fundació Enciclopèdia Catalana, 2001 , vol. 6 .

${ }^{64}$ CORTÉS I MIR, Francesc. "La música religiosa". Història de la Música Catalana, Valenciana i Balear .Barcelona: Edicions 62, 2000, volum III. p. 232-234

${ }^{65}$ GALDON ARRUÉ, Monti. Els mestres de capella de la catedral de Girona durant la primera meitat del s.XIX. Recerca Musicològica, XIII, Universitat Autònoma de Barcelona.

Aquest article se cita a la p. 258 del Tom III. 
relacionats amb la capella, seguint el criteri dels períodes de crisi de la mateixa. ${ }^{66}$

${ }^{66}$ Aquestes informacions, així com el criteri cronològic dels períodes de crisi i l'evolució corresponent de la capella, no pertanyen a l'artice citat, sinó que són extrets del meu treball de recerca, fonament del present estudi sobre la música a la catedral de Girona. Per a més informació, vegi's GALDON ARRUÉ, Monti. La capella de música de la catedral de Girona, del 1800 al 1850. Barcelona: U.A.B., 1998. Treball de recerca. 


\section{METODOLOGIA GENERAL}

\section{PROCEDIMENT}

El primer pas ha estat la lectura de la bibliografia existent, sobretot els treballs del mestre Civil, i la consulta en l'arxiu de la catedral de diverses partitures del segle XIX.

L'eix vertebrador del treball s'ha realitzat a partir de la minuciosa lectura de tots i cada un dels llibres de Resolucions Capitulars pertanyents a la primera meitat del segle XIX, i la fidel transcripció dels fets relacionats amb la capella de música, els seus integrants i les pautes de funcionament de la mateixa. Amb aquest procediment s'ha obtingut gran quantitat d'informacions disperses, que s'han ordenat, seleccionat i complementat amb la lectura exhaustiva de la resta de fonts existents a l'Arxiu de la Catedral, com poden ser els Llibres de Comptes de l'Obra, els Llibres de la Comunitat de Beneficiats, el Llibre de Noms i Cognoms i la Correspondència Capitular, entre altres.

Quan la investigació es trobava en aquest punt, vaig dubtar entre realitzar una tesi de caire general, o bé centrada en l'estudi d'un compositor, com podia ser l'organista Antoni Guiu, investigar els seus trets biogràfics i transcriure i analitzar la totalitat de les seves obres, ja fossin religioses o no. Però em va saber greu no donar una sortida concreta al dens corpus documental que tenia entre mans. També em va semblar més profitós elaborar un estudi de caire general, que obrís un ampli ventall de possibilitats per a posteriors investigacions $\mathrm{i}$ investigadors. D'aquesta manera es podran dur a terme múltiples recerques, ja siguin centrades en compositors concrets, en grups d'obres o en la comparació 
de capelles de música de diferents indrets, doncs ja es disposarà d'un estudi inicial.

En el moment de prendre la determinació de continuar amb aquesta tesi, vaig consultar altres arxius, com el de Vic $i$ el de Sta. Maria del Pi. Les informacions obtingudes m'ajudaren per acabar de lligar caps. Vaig anar a l'Hemeroteca de l'Arxiu Municipal de la Ciutat de Girona per obtenir punts de referència que em permetessin relacionar les informacions obtingudes a l'Arxiu Capitular amb els principals esdeveniments de l'època. En aquest punt de la investigació també ha estat de gran ajuda la consulta de la base de dades RILM.

Finalment, i seguint l'ordre cronològic del treball que ha donat lloc a aquesta tesi, s'han transcrit un determinat nombre d'obres i se n'ha realitzat la seva anàlisi. La inclusió de les obres musicals en aquest estudi, mostra una pinzellada de l'activitat compositiva d'alguns dels individus que formaven part de la capella, i en complementa el caràcter històric.

\section{ESTRUCTURA DEL TREBALL}

La tesi es divideix en set capítols amb continguts ben diferenciats. L'estructuració d'aquests s'ha realitzat de forma inductiva ${ }^{67}$; com es pot comprovar amb el títol donat a cada capítol, s'ha partit dels temes més generals, per anarse progressivament acostant als més particulars. Al final de cada capítol hi ha un apèndix amb la transcripció de documents d'interès i que donada la seva extensió no era recomanable introduïr-los de forma completa en la redacció.

${ }^{67}$ CHALMERS, Alan F. ¿Qué es esa cosa llamada ciencia?. Madrid: s.XXI, 1988. 
El capítol I titulat "Marc històric: Girona a la primera meitat del segle XIX", és un breu estudi de les circumstàncies socials, polítiques, econòmiques, culturals i educatives que envoltaven els ciutadans gironins. Té un últim apartat dedicat al paper que la catedral tenia en la vida de la ciutat. Per a aquest capítol, s'ha buidat la bibliografia publicada referent a la ciutat de Girona. Així com la bibliografia del segle XIX en general. Cal dir que en aquest capítol no tracto de fer aportacions originals, només contextualitzar en certa mesura la capella de música en el seu entorn quotidià.

El capítol II, titulat "La capella de música de la catedral de Girona durant la primera meitat del segle XIX", està subdividit en diversos apartats que expliquen aspectes concrets de la capella. Els apartats tracten la composició general de la capella, les pautes de funcionament, les funcions musicals que es realitzaven, els períodes de crisi política i social de l'època i la seva repercusió en la capella de música, els recursos humans i materials de què es disposava, la situació social i econòmica dels músics, així com la pertinent transcripció de documents.

El capítol III, titulat "Els integrants de la capella de música", conté l'estudi de tots i cada un dels individus que formaven part de la capella, començant pels mestres de capella, els escolans, els organistes, els cantors....En cada apartat s'han introduït tots els músics que en algun moment passaren per la capella, ja fos com a titulars de la plaça, substituts $o$ interins. També $m$ 'ha semblat interessant incloure-hi els individus que es presentaren com a candidats a les oposicions, sense obtenir la plaça, doncs poden ser informacions d'interès per als investigadors/es que en facin el seguiment. Cal dir que quan s'ha realitzat l'estudi d'un músic del qual ja hi ha notícies publicades, en un peu de plana hi he fet l'entrada amb la informació que ja es coneix 
i la font d'on l'he treta. El cos del treball conté principalment les informacions aportades per la recerca. El final d'aquest capítol conté la transcripció de documents.

El capítol IV, titulat "Les obres manuscrites conservades d'autor", es realitza un inventari de les obres escrites pels integrants de la capella de música durant els cinquanta anys objecte d'estudi, conservades a l'Arxiu Capitular de la Catedral de Girona i la Biblioteca de Catalunya.

Al capítol V, titulat "Anàlisi de la música instrumental", hi apareix l'anàlisi contextualitzada de cada una de les obres estudiades.

Al capítol VI, titulat "Edició crítica de les obres", hi ha la transcripció de les quatre obres musicals així com una relació d'esmenes per cada una de les composicions.

El darrer capítol, el VII, conté les "Conclusions generals"; en l'apèndix de làmines que el segueix es pot veure una taula amb tots membres que integraren la capella de música, durant els cinquanta anys objecte d'estudi; finalment trobem la "Bibliografia" i 1" "Índex onomàstic".

Els set capítols s'agrupen en quatre volums. En el primer volum hi ha el preàmbul, la introducció i els capítols I i II.

En el segon volum hi ha el capítol III, dedicat íntegrament als membres que formaven part de la capella.

En el tercer volum hi ha els capítols IV, V i VI, amb l'edició crítica de dues de les obres; degut a la llargada d'aquestes s'han posat dues obres musicals en cada volum. 
En el quart volum hi ha la resta del capítol VI, amb l'edició crítica de dues obres restants, i el capítol VII.

\section{CRITERIS EN LA TRANSCRIPCIÓ DELS MANUSCRITS}

Per imperatius socials i polítics de l'època, la majoria de manuscrits són en castellà; cal dir que no he considerat adient traduir-los. En les transcripcions de manuscrits, he mirat de respectar el màxim possible el text original, intervenint-hi només quan la lectura del text esdevenia molt dificultosa. Per aquest motiu no he desenvolupat la majoria d'abreviatures, fórmules molt corrents en el segle XIX, i que generalment no entorpeixen gens la lectura del text. Només ho he fet en casos molt excepcionals, en aparèixer abreviatures més estranyes que són poc freqüents. Seguint aquesta tendència de respecte als textos originals, no he variat aspectes com la puntuació i l'accentuació.

En els documents catalans s'han seguit els mateixos criteris anteriorment descrits.

Seguint aquesta línia de respecte als textos originals, no he normalitzat els cognoms dels integrants de la capella; així, quan parlo del mestre de capella Jaume Joan Lleys, deixo la grafia $y$ com en els textos originals i no la bescanvio per $i$. El mateix faig amb els plurals de Bassas $\mathrm{i}$ Quilmetas, que no s'han normalitzat segons les regles ortogràfiques actuals. Cal remarcar, que la recent Gran Enciclopèdia de la Música, també respecta la grafia original dels cognoms, com podem veure en l'entrada del mestre Rafael Compta, escrit amb a i no amb $e$, com faríem avui dia. 


\section{METODOLOGIA APLICADA A L'ANÀ- LISI MUSICAL}

\section{CRITERIS PER A LA SELECCIÓ DE LES OBRES}

A l'arxiu de la catedral es conserven aproximadament unes cinc-centes obres de la primera meitat del segle XIX. Com és natural en tota producció catedralícia, un grup molt important d'aquestes obres són litúrgiques (misses, salms, himnes, responsoris, motets, etc.), que s'acullen a la tradició musical eclesiàstica de textura marcadament contrapuntística i textos en llatí. ${ }^{68}$

Hi ha un segon important bloc d'obres també vocals, però $\mathrm{amb}$ text en llengua vernàcula, la majoria d'elles en castellà, tot i que també n'hi ha en català. Es conserven sobretot villancets, goigs i rosaris. Els villancets estan composats per a diverses festivitats del calendari, i es troben dividits en dos grups: villancicos serios i villancicos burlescos.

Finalment, hi ha una petit nombre d'obres purament instrumentals, l'abast de les quals traspassa el dels murs de la catedral, ja que deurien estar composades per a les acadèmies que realitzaven les famílies benestants, el teatre...

Quan ja tenia clar que volia fer un estudi general de la capella de música de la catedral, vaig pensar en transcriure $\mathrm{i}$ treballar una missa i un villancet de cada un dels mestres de capella que passaren per la catedral, i analitzar així estil antic $i$ estil modern. Tot $i$ això, en l'àmbit català, ja hi ha

\footnotetext{
${ }^{68}$ Per a veure l'inventari de les obres manuscrites, vagi's al cap.IV.
} 
interessants treballs a partir de l'estudi i l'anàlisi dels villancets $^{69} \mathrm{i}$ els oratoris $^{70}$. Durant un temps vaig estar temptada de transcriure els Te Deum, doncs en les actes capitulars vaig anar trobant valuoses informacions dels motius de celebració de cada Te Deum; m'ho vaig tornar a considerar perquè faltaven la majoria de partitures a què feien al·lusió les actes. Finalment em vaig decantar per la transcripció i l'estudi de les obres instrumentals. La raó essencial és que hi ha pocs estudis referents a les obres instrumentals de la primera meitat del segle $\mathrm{XIX}^{71}$; cal tenir en compte que el nombre de manuscrits que ha arribat als nostres dies és relativament reduït, si el comparem amb la gran quantitat de música religiosa conservada en els arxius d'esglésies i catedrals. A més, vaig pensar que aquestes obres reflexarien més directament els canvis musicals operats en els gustos d'una societat que estava canviant a un ritme vertiginós. També va ser un motiu important que algunes composicions fossin escrites per a un instrument $o$ un petit grup instrumental; d'aquesta manera pot ser més factible la seva interpretació i divulgació.

De l'organista Antoni Guiu disposem de sis obres instrumentals. Dels compositors estudiats és el de producció més extensa, tant pel que fa a la música vocal, com instrumental. A l'Arxiu Capitular de la Catedral de Girona,

69 RIFÉ I SANTALÓ, Jordi. Els villancets d'Emmanuel Gònima (1712-1792). Un model de la transició del barroc al preclassicisme a la Catalunya del segle XVIII, tesi doctoral. Barcelona : U.A.B., 1992.

70 DAUFÍ RODERGAS, Xavier. Estudi dels oratoris de Francesc Queralt (1740-1825). Fonaments de la història de l'oratori a Catalunya al segle XVIII, tesi doctoral. Barcelona: U.A.B., 2000.

${ }^{71}$ Entre els pocs treballs en aquesta línia hi ha els estudis realitzats per J.M ${ }^{\text {a }}$ Vilar: VILAR i TORRENS, Josep Maria. La simfonia a Catalunya. 1760-1808, Treball de recerca. Barcelona: U.A.B., 1993. I del mateix, Les simfonies de Carles Baguer: fonts, context $i$ estil, Tesi doctoral. Barcelona: U.A.B., 1994. 
es troben els Ä̈rs per a piano ${ }^{72}$; la Introducción $y$ variaciones para piano y violín; la Sinfonía para piano, flauta $y$ violín, completa però en molt mal estat de conservació i les Yntroduccion y Variaciones para piano, flauta y fagote obligados. I a la secció de manuscrits musicals de la Biblioteca de Catalunya, tenim dues obres, la Sinfonia obligada de organo, para violines, viola, flauto, clarinetes, corni, organo y basso i la Sinfonía $n^{\circ} 7$ a toda orquesta reducida por el mismo para Piano, Flauto y Violín Obligado.

De les tres obres de l'Arxiu Capitular de la Catedral de Girona n'he transcrit la Yntroducción y Variaciones para piano, flauta y fagote obligados, per ser l'obra que es troba en millor estat de conservació, a més de ser de factura molt semblant a la Introducción y variaciones para piano $y$ violín. De les dues obres de la Biblioteca de Catalunya, n'he transcrit la Sinfonia con orquesta obligada de organo, tot i estar en mal estat de conservació, ja que reverteix més interès musical que no pas la reducció de la Sinfonia $n^{\circ} 7$.

Del mestre de capella Jaume Joan Lleys, n'he fet la transcripció del seu Tema con Variaciones para el Violoncello à toda Orquesta de l'Arxiu Capitular de la Catedral de Girona. De moment, es tracta de l'única partitura totalment instrumental que diposem d'aquest compositor.

Del contrabaixista de la capella de música de la catedral Miquel Albert, n'he transcrit les Quatro Sonatas manuscrit musical conservat a la Biblioteca de Catalunya.

\footnotetext{
${ }^{72}$ Obra en procés de transcripció.
} 


\section{CRITERIS DE TRANSCRIPCIÓ I REVISIÓ CRÍTICA DE LES OBRES MUSICALS}

En el cas d'errors molt evidents d'alteracions o d'altra mena, són especificats en l'apartat d'esmenes al final de cada transcripció, indicant sempre el nombre del compàs on apareix la correcció i la naturalesa del canvi.

Cal fer esment del precari estat dels manuscrits; la majoria són borradors de les obres amb múltiples correccions $i$ canvis en el mateixos, dificultant-ne considerablement la lectura. Només un dels manuscrits s'ha trobat amb una grafia clara, es tracta de la còpia de Francesc Creuet de les particel-les del Tema con Variaciones para el Violoncello à toda Orquesta de Jaume Joan Lleys. Es poden veure reproduccions de les mostres de l'estat dels manuscrits en l'apèndix de làmines del Volum IV.

No s'ha afegit cap signe d'expressió, accentuació o matís, només s'ha transcrit els propis de les obres. Totes els manuscrits porten indicacions tant en castellà com en italià ; en tot moment s'ha respectat l'escriptura original.

Pel que fa al còmput de compassos, les anacruses han estat comptabilitzades com a compassos reals. També s'han normalitzat, segons l'escriptura actual, els signes de repetició indicant els fragments musicals pertanyents a la primera i a la segona repetició, doncs en les dues partitures d'Antoni Guiu hi trobem forces irregularitats en relació amb aquest aspecte.

En les partitures generals de les dues obres orquestrals transcrites, s'ha seguit el criteri actual en l'ordre d'escriure els instruments, doncs sembla que se'n facilita considerablement la lectura. En l'obra de Jaume Joan Lleys, Tema con Variaciones para el Violoncello à toda Orquesta, 
només s'han conservat les particel-les. En l'obra Sinfonía con orquesta obligada de órgano s'ha conservat la partitura original i l'ordre dels instruments és el típic de l'època, colllocant els violins primers i segons, seguits de flauta, clarinets, trompes, l'orgue i el baso.

Per a la transcripció de les obres s'ha utilitzat el programa informàtic Encore 4.1.0.

\section{CRITERIS D'ANÀLISI MUSICAL}

En l'anàlisi de cada una de les quatre obres transcrites, s'han treballat els mateixos paràmetres musicals. Aquests són: l'estructura formal; els elements melòdics i rítmics; els aspectes tímbrics; la textura; els elements expressius i la valoració estilllística general. El fet d'utilitzar els mateixos paràmetres en totes les obres, a més de permetre'm un estudi bastant sistemàtic de cada una d'elles, dóna la possibilitat d'establir relacions entre els paràmetres de les diferents obres.

En analitzar l'estructura formal de les obres es té en compte tant l'estructura tonal com la temàtica; sovint s'han utilitzat conceptes com melodia, frase, període i cèdul·la.

Pel que fa a l'anàlisi dels elements harmònics, s'ha observat quins són els tipus d'enllaços tonals més freqüents, els sistemes de modulació, així com la utilització de determinats acords o girs harmònics.

En l'apartat dels elements melòdics i rítmics, s'analitza més profundament la construcció de les melodies, o temes principals, amb el nombre de frases, i períodes que tenen. També s'estudia la naturalesa motívica utilitzada en les introduccions, ponts i codes. Pel que fa als ritmes, es té 
en compte si hi ha predominància o repetició de certs models rítmics, així com la utilització en l'obra dels grupets i els mordents.

Per a la textura em baso en els criteris de classificació utilitzats per Piston en el seu tractat d'orquestració ${ }^{73}$ que consisteixen en l'uníson orquestral, la melodia acompanyada, la melodia secundària, l'escriptura a vàries veus, la contrapuntística, els acords orquestrals i la textura complexa.

En l'apartat dels elements expressius faig constar els diferents signes utilitzats per cada un dels compositors en les seves obres, comento si n'apareixen molts o pocs i com estan escrits.

Els aspectes tímbrics, en les obres orquestrals, comprenen l'estudi dels instruments pels que està escrita cada obra, amb l'àmbit de cada particel·la, així com les particularitats interessants a comentar que puguin sorgir. En alguns casos també es comenten alguns detalls de l'orquestració.

La valoració estil·lística general és un compendi dels aspectes analitzats en els punts anteriors relacionant-los amb l'època en què l'obra fou escrita, i els contingents personals $\mathrm{i}$ instrumentals de la capella catedralícia en aquell moment.

S'han utilitzat els índexs acústics del sistema francobelga de numeració les octaves, prenent com a punt de partida el do que, en clau de fa amb quarta, escrivim a sota del pentagrama amb dues addicionals: aquest seria el $\mathrm{do}_{1}$.

${ }^{73}$ PISTON, Walter., Orquestación. Madrid: Real Musical, 1992, p. 380 i següents. 


\section{SIGLES I ABREVIATURES}

\section{SIGLES GENERALS}

a) Dels arxius consultats

ACCG: Arxiu Capitular de la Catedral de Girona. APSMP: Arxiu Parroquial de Santa Maria del Pi.

AEV: Arxiu Episcopal de Vic.

HAMCG: Hemeroteca de l'Arxiu Municipal de la Catedral de Girona.

AOC: Arxiu Orfeó Català.

BC: Biblioteca de Catalunya.

b) De les fonts de l'Arxiu Capitular de la Catedral de Girona.

Ll.R.C.: Llibres de resolucions capitulars.

Ll.C.O.: Llibres de Comptes de l'Obra.

N.iC.: Llibre de noms i cognoms.

Co.: Correspondència Capitular.

D.C.B.: Documents de la Comunitat de Beneficiats.

P.iO.: Possessions i obits.

\section{ABREVIATURES}

$1 .^{\text {ro }}:$ primero.

9. ${ }^{\text {bre }}$ : Noviembre.

a. $^{\text {s. }: \text { años. }}$

Adm. ${ }^{\text {res }}$ : Administradores.

Admin.: Administradores.

Ant..$^{\circ}$ : Antonio.

art. :article. 
Benef. ${ }^{\text {do }}$ : Beneficiado.

Bern. ${ }^{\text {do }}$ : Bernardo.

c. : compàs.

Cab. ${ }^{\circ}, \mathrm{Cab}^{\mathrm{do}}{ }^{\text {: Cabildo. }}$

Can. ${ }^{\circ}$ : Canónigo.

cap. :capítol.

Cap. ${ }^{\text {a: }}$ Capilla.

Cap. ${ }^{\text {r: }}$ Capitular.

Cath. ${ }^{\text {: }}$ Catedral.

cb.: contrabaix.

Certif. $^{\text {on }}$ : certificación.

cl.: clarinet.

Cler. ${ }^{\circ}$ : Clerigo.

col. : col·lecció.

Com. ${ }^{\text {on }}$ : Comisión.

Com. ${ }^{\text {s: }}$ Comisarios.

consig. ${ }^{\text {te }}$ : consiguiente.

Constit. ${ }^{\text {s: }}$ Constituciones.

cs. : compassos.

d.: diners.

D.: Dominant.

D.: Don

D. ${ }^{\mathrm{n}}$ : Don

DD. : Dominant de la dominant.

des. ${ }^{\text {bre }}$ : desembre.

dhos: dichos.

Dic. ${ }^{\text {bre }}$ : diciembre.

difun. ${ }^{\circ}$ : difunto.

doc.: document.

Dr.: Doctor.

ed.: edició, editat, editorial.

Excmo: Excelentísimo.

$f$ : forte.

fag.: fagot.

$f f$ : fortísimo.

fl.: flauta. 
fol.: foli.

fols: folis.

Fran. ${ }^{\mathrm{co}}$ : Francisco.

Fran. ${ }^{\text {ch }}$ : Francesc.

Gen. ${ }^{\text {les: }}$ Generales.

Ger. ${ }^{a}$ : Gerona.

Grales: Generales.

Igl. ${ }^{a}$ : Iglesia

igual. ${ }^{\text {te }}$ : igualmente.

I11: Ilustrísimo.

Itt: Item.

lic. ${ }^{a}:$ licencia.

licen. ${ }^{\mathrm{a}}$ : licencia.

11.: 1liures.

M. : Major.

m.: menor.

M.I.S.: Muy Ilustre Señor.

M. ${ }^{\mathrm{n}}$ : Mossèn.

$\mathrm{M}^{\text {tro }}$ : Maestro.

M.Y.C.: Muy Ilustre cabildo.

M.Ylle.C.: Muy Ilustre Cabildo.

Man.': Manuel.

Mem. ${ }^{1}$ : Memorial.

Memor. ${ }^{\mathrm{s}}$ : Memoriales.

Mig $^{1}$ : Miguel.

Monast. ${ }^{\circ}$ : Monasterio.

Mtro: Maestro.

N. ${ }^{\text {bre }}$ : Noviembre.

n. ${ }^{\text {bre }}$ : noviembre.

nat. ${ }^{1}$ : natural.

Not. ${ }^{\circ}$ : Notario.

Not. ${ }^{\mathrm{s}}$ : Notarios.

Nov. ${ }^{\mathrm{e}}$ : Noviembre.

num. ${ }^{\circ}$ : número.

ob.: oboè.

Ob.cit. : Obra citada. 
Oblig. ${ }^{\mathrm{n}}$ : Obligación.

obligac. ${ }^{\text {s: }}$ obligaciones.

Org.:orgue.

Org. ${ }^{\text {no }}$ : Órgano.

Organ. ${ }^{\text {ta }}$ : Organista.

p.: pàgina.

p. ${ }^{\text {a }}$ : para.

p. ${ }^{\circ}$ : proximo.

p. ${ }^{\mathrm{r}}$ : por.

$P$ : piano.

Par. ${ }^{\text {tes }}$ : Parientes.

Parroq. ${ }^{1}$ : Parroquial.

Porq. ${ }^{\mathrm{e}}$ : por que.

pp: pianísimo.

Presid. ${ }^{\text {te}}$ : Presidente.

Pret. ${ }^{\text {te }}$ : Pretendiente.

Prim. ${ }^{\text {te }}$ : Primeramente.

ps.: pàgines.

pte.: presente.

q. ${ }^{\mathrm{e}}$ : que.

R.: Reverendo.

$\mathrm{R}^{\mathrm{a}}{ }^{\mathrm{a}}$ : Resolverá.

R. ${ }^{\text {do }}$ : Reverendo.

R. ${ }^{\mathrm{n}}$ : Resolución.

$\mathrm{R}^{\mathrm{nt}}$ : Reverend.

R.R.: Reverendos.

Res.: Resolución.

Res. ${ }^{n}$ : Resolución.

Resol: Resolución.

S.: San.

s.: sous.

S.M.: Su Majestad.

S. ${ }^{n}:$ San

$S .{ }^{\text {or: }}$ Señor.

S.S.: Señores.

S. $S^{a}$.: Su Señoría. 
S. ${ }^{\text {ta }}$ : Santa.

SD. : Subdominant.

Sec. ${ }^{\circ}$ : Secretario.

Secret. ${ }^{\circ}$ : Secretario.

Sept.: Septiembre.

Sept. ${ }^{\text {bre }}$ : Septiembre.

Ser. ${ }^{\text {dor }}$ : Servidor.

Sn.: San.

Sor.: Señor.

St.: Sant.

Sta.: Santa.

T. : Tònica.

tr.: trompa.

ultim. $^{\text {te }}:$ ultimamente.

V.S.: Vuestra Señoría.

V.S.Y.: Vuestra Señoría Ilustrísima.

V.Y.: Vuestra Ylustrísima.

$\mathrm{v}$ : vers.

vl.: violí.

vla.: viola.

vlc.: violoncel.

vol.: volum.

vols.: volums.

$\mathrm{Y}^{\mathrm{m}}$ : Ítem.

Y11. ${ }^{\mathrm{mo}}$ : Ilustrísimo.

Ytt.: Ítem. 
CAPÍTOL I

\author{
MARC HISTÒRIC: \\ GIRONA A LA PRIMERA \\ MEITAT DEL SEGLE XIX
}




\section{GIRONA A LA PRIMERA MEITAT DEL SEGLE XIX}

Girona, cap de comarca del Gironès i capital de la província homònima, és encaixada entre els massisos muntanyosos de les Guilleries, les Gavarres i el Rocacorba, a la confluència dels rius Ter, Onyar, Güell i Galligans. La seva part antiga s'assenta sobre un terreny accidentat, dalt d'un turó d'on es podia controlar tot el pla que l'envoltava i que n'aconsellà ben aviat el seu emmurallament. L'estructura emmurallada és d'època baix-imperial; entre el segle IX i començaments del segle $\mathrm{X}$, hi vivien a intramurs unes mil persones, dins l'anomenat recinte de la Força Vella $^{74}$. Aquesta estructura persisteix fins l'alta edat mitjana, i fins a les darreries del segle XIX és tota voltada de muralles.

Les circumstàncies de vida dels gironins durant els primers cinquanta anys del segle XIX foren molt dificultoses. El seu emplaçament geogràfic i estratègic de gran proximitat amb la frontera francesa, li ocasionà veure's immergida en nombroses conteses amb França. La situació política, constantment canviant, és també un important factor que condiciona la vida ciutadana en aquells anys.

A les darreries del segle XVIII, vers el 1787, Girona voltava els 8000 habitants $^{75}$; des de la Guerra de Successió el seu creixement vegetatiu havia estat molt discret. El 1793 esclata la Guerra Gran i la ciutat entra en un període de grans penúries que s'allargarà fins els setges de 1808-1809.

${ }^{74}$ SALRACH I MARÉS, Josep M. "Ciutat i cultura" a Història de Girona. Girona: Adac, 1991-2000. p. 107

75 ALBERCH I FUGUERAS, Ramon. "Girona i les guerres del francès"dins Història de Girona. Girona: Adac, 1991-2000. p. 237 
Girona esdevé el centre neuràlgic d'organització de l'exèrcit de Catalunya: s'hi subministren queviures i s'hi allisten soldats. Dels 18660 soldats quintats al partit de Girona, un miler residien a la ciutat, dada que evidencia la magnitud d'allistament d'habitants de la contrada ${ }^{76}$. Com que Girona actuava com a centre hospitalari, els soldats malalts s'acumularen en gran nombre. A tot això s'hi sumà el col-lapse del comerç i una forta emigració cap a la ciutat, sobretot de famílies que fugien del front $\mathrm{i}$ de francesos benestants que s'amagaven per motius ideològics. Tot i que el conflicte bèl-lic armat no afectà directament la ciutat, els seus efectes sobre la població i l'economia foren molt destacables. De fet, quan el 1795 se signà la Pau de Basilea i la guerra fineix, Girona es troba en una situació difícil que s'allargarà fins l'esclat de la Guerra del Francès. L'impacte demogràfic és destacable: pel 1797, el nombre d'habitants havia baixat a $7120^{77}$. Tot $\mathrm{i}$ els possibles errors dels censos de l'època, és clara la influència del conflicte.

Començat el segle XIX, poc abans del primer setge ${ }^{78}$, Girona era una ciutat amb marcades diferències socials, en declivi econòmic i amb un elevat percentatge de béns $\mathrm{i}$ riqueses en mans de la noblesa i el clergat. Per altra banda, l'octubre de 1807, el govern espanyol presidit per Godoy signa secretament amb Napoleó el tractat de Fontainebleau, on s'acorda la partició de Portugal ${ }^{79}$, a més

\footnotetext{
${ }^{76}$ Idem.

${ }^{77}$ Idem.

78 Alguns autors, com Joaquim Pla i Cargol, consideren el primer setge l'atac del 20 i 21 de Juny de 1808. Molta altra bibliografia data el primer setge al període d'ocupació entre juliol i agost de 1808. En el present estudi trobem més lògica aquesta darrera data.

${ }^{79}$ Godoy es deixà enlluernar pel promès regne dels Algarves.
} 
de reconèixer Carles $\operatorname{IV}^{80}$ com a Emperador de les Amèriques ${ }^{81}$. A canvi, les tropes franceses, com a aliades de la monarquia espanyola, travessarien els Pirineus amb la intenció d'ocupar Portugal i establir un bloqueig contra Anglaterra. Cap al gener de 1808, un contingent de 9000 soldats s'endinsa per la Península i arriben a Castella en menys d'un mes.

Les tropes franceses fan la seva irrupció a Girona el deu de febrer de 1808. D'entrada els generals francesos consideren irrellevants i ineficaces les fortificacions de la ciutat, molt malmeses arran de la Guerra Gran, i seguiren el seu camí cap a Barcelona.

L'odi popular a Godoy creix, fins que finalment és detingut pel març de 1808, a l'aixecament popular d'Aranjuez. Conseqüència d'això és l'abdicació de Carles IV a favor del seu fill Ferran. ${ }^{82}$ Els francesos no reconeixen la nova monarquia $i$ a finals d'abril, Ferran accedeix a tornar el tron al seu pare, en les conversacions entre ambdós, Napoleó i Godoy, posat ja en llibertat. Després de l'aixecament popular contra els francesos a Madrid el dos de maig i el del dur aplacament que en segueix, Carles

${ }^{80}$ El rei Carles IV visità Girona el 23 d'octubre de 1802 , amb els prínceps i el rei d'Etrúria. Es cantà un Te Deum. Vegi's l'apartat 3.c "Funcions musicals de la capella", en aquest mateix capítol.

${ }^{81}$ Pel novembre de 1806, Godoy havia negociat secretament amb Napoleó amb l'objectiu que aquest el recolzès totalment, per mor de trobar-se cada cop més insegur davant del príncep Ferran. El 30 d'octubre de 1807, tres dies després de la signatura del tractat, processen el príncep Ferran acusat de conspiració per a derrocar el seu pare, Carles IV, i acabar amb Godoy. Ferran es retractà i demanà clemència al seu pare, qui el perdonà. Aquest fet afavoria els plans més íntims de Napoleó respecte la Península Ibèrica, just en el moment que culminava el seu poder imperial.

${ }^{82}$ Es feren rogatives per a que el rei Ferran VII governés amb encert, el divuit d'abril de 1808. Vegi's 1'apartat 3.d dintre de les "Funcions musicals de la capella”, en aquest mateix capítol. 
IV recupera el tron el tretze de maig. Pocs dies més tard, aquest cedeix els seus drets com a monarca a Napoleó, amb la condició que no desmembri el regne d'Espanya i mantingui la religió catòlica. L'estratègia pensada per Napoleó d'actuar de mitjancer entre els conflictes domèstics de la monarquia espanyola sorgí el seu efecte, proclamant Josep Bonaparte com a rei d'Espanya, el vint de juliol de 1808 , enmig d'una freda acollida popular.

Les insurreccions populars es multipliquen per diversos factors: hi ha un descontentament social envers l'estancament econòmic, una creixent gal-lofòbia propiciada pel record de la Guerra Gran, les esperances dipositades en la figura idealitzada de Ferran VII per donar sortida a la crisi i una forta decepció de l'actuació del govern de Godoy.

A Catalunya, el poble no tardarà a reaccionar davant l'ocupació del país anunciada com a passatgera, pel suposat poder aliat, però que cada vegada era més definitiva $\mathrm{i}$ irritant. Cap al juny de 1808 es creà a Girona una Junta de defensa $^{83}$ influenciada pel clergat $i$ el sector més popular, tot i l'oposició relativa de les parts més benestants i el

\footnotetext{
${ }^{83}$ El divuit de juny de 1808 , es creà a Lleida la Junta Superior de Catalunya, que havia de vetllar per la bona coordinació de la resistència i la vinculació amb els fets a la resta de la Península, però sense plantejar l'actuació com a expressió d'una política catalana específica. Com explica Josep Fontana al volum V de la Història de Catalunya, va ser la culminació d'un procés d'aparició d'autoritats insurreccionals, nascudes de la pressió popular que exigia a les autoriatats que declaressin si volien seguir lo partit español, com lo mateix poble ho reclamaba. A això hi afegirem el que s'explica al Diccionari d'Història de Catalunya, dirigit per Jesús Mestre i Campi: La guerra del Francès va posar de manifest que en la lluita per l'afirmació d'un nou estat, els plantejaments i comportaments politics que es donaven a Catalunya eren d'una evident adhesió a la causa del naixent nacionalisme espanyol; la qual cosa encaixava, alhora, amb el progressiu afebliment de la catalanitat en els plantejaments politics del set-cents. ROURA I AULINAS, Lluís. "Guerra del francès"en Diccionari d'Història de Catalunya. Barcelona: Edicions 62, 1992. p. 479.
} 
govern. La ciutat es comença a revoltar contra els ocupants, i aquests responen amb un assalt els dies vint i vint-i-ú de juny, comandat pel general Duhesme ${ }^{84}$ amb un contingent de 5000 homes. Aquest general volia reduir la resistència a Girona per mantenir expedites les seves comunicacions amb la frontera francesa, i se'n penedí de no haver-ho fet quan les primeres forces napoleòniques hi passaren. Els gironins feren fracassar l'atac, en part per la ràpida reparació que s'havia fet de muralles i baluards. Duhesme emprèn la retirada en comprendre que havia subestimat la resistència, $i$ que li mancaven soldats i artilleria per establir un setge en tota regla.

Aquesta victòria animà els gironins qui, convençuts de que la protecció del sant patró, el màrtir Sant Narcís, havia estat clau en els fets, decidiren designar-lo Generalíssim en una celebració a la capella del sant. ${ }^{85}$

El vint de juliol el general Duhesme torna amb un exèrcit de 11000 homes i molta més artilleria ${ }^{86}$. A Girona, com a reforç, havien arribat abans dos batallons del regiment de Borbó i el segon batalló de voluntaris de Barcelona. Els gironins anaren contenint els repetits atacs

\footnotetext{
84 Aquest general havia ocupat Barcelona pel febrer amb més de 15000 homes. Es produïren emigracions massives cap a Tarragona i Mallorca de molts ciutadans benestants.

${ }^{85}$ El vint-i-cinc de juny de 1808 se celebra un ofici i Te Deum a Sant Narcís en acció de gràcies per la victòria contra les tropes franceses, que volien assaltar la ciutat. Se'n celebra un altre el tres de juliol. De fet, a partir de llavors i fins el 1820, aquest ofici solemníssim es faria cada vint de juny. Per a més informació, vegi's l'apartat 3.e dintre de les "Funcions musicals de la capella", l'apartat 4 dels "Períodes de crisi" i consulti's 1'apèndix 3: Documents relacionats amb els setges.

86 ALBERCH I FUGUERAS, Ramon. "Girona i les guerres del francès”, Història de Girona. Girona: Adac, 1991-2000. p. 240
} 
dels assetjadors, resistint en situació molt crítica ${ }^{87}$. Finalment, el vint d'agost de 1808, mitjançant una operació perfectament coordinada entre les forces de la ciutat i les enviades per la Junta Superior de Catalunya, els francesos es retiraren enmig d'un gran desconcert i desorientació, ja que tot havia estat comès per sorpresa. Un important carregament de queviures fou introduit a la ciutat. ${ }^{88}$

Passarien vuit mesos abans que els francesos tornessin a atacar la ciutat; aquest període s'aprofità per reforçar les defenses, augmentar el contingent de soldats i reorganitzarse. Cal dir que a finals de 1808, Duhesme estava del tot bloquejat a Barcelona. Per reforçar les formacions franceses, entrà per la Jonquera un poderós exèrcit comandat pel mariscal Saint-Cyr, que evità topar amb les defenses de Girona, i es dirigí cap a Barcelona desviant-se vers el Baix Empordà. Aquest contingent fou observat per una avantguarda de l'exèrcit espanyol de Catalunya, que s'instal-là a la vorera dreta del riu Fluvià. El general Àlvarez de Castro n'era el cap de les tropes. En una ordre d'aquest general de reconeixement de la vorera esquerra del riu, es rebé com a rèplica una forta escomesa dels invasors, per la qual cosa es veieren obligats a retirar-se i afermar-se

${ }^{87}$ El nou d'agost de 1808 fan una rogativa a Sant Narcís perquè els doni forces per a triomfar davant els enemics. Vegi's l'apartat 3.e , dintre de "Funcions musicals de la capella".

${ }^{88}$ El disset d'agost de 1808 , missa i Te Deum a la capella de Sant Narcís per haver fugit l'enemic la nit anterior, després de 25 dies de setge. Vegi's l'apartat 3.e dintre de les "Funcions musicals de la capella".

El vint-i-cinc d'agost, sermó i Te Deum pel mateix motiu, encomanat per la Junta de la Ciutat.

En data de divuit d'agost, queda constància en els Ll.R.C. com el setge havia afectat la teulada de la catedral i les cases. Consulti's el document 5 de l'apèndix relacionat amb els setges. Per altra banda, en les actes del catorze d'octubre de 1810 s'hi comenta que l'orgue també havia sofert les conseqüències dels setges; vegi's l'apartat dedicat a l'orgue gran, dintre dels "Recursos instrumentals", en aquest mateix capítol . 
en les defenses de Girona. El capità general de Catalunya donà l'ordre que Àlvarez de Castró unís al càrrec de comandant de l'avantguarda de l'exèrcit de Catalunya, el càrrec de Governador de Girona i dels seus forts. El general posà en aquella missió de defensa de Girona tot el seu patriotisme i la resolució de sacrificar-ho tot abans de rendir la ciutat. ${ }^{89}$ Arribà a publicar un enèrgic ban el primer d'abril de 1809, on s'amenaçava amb pena de mort a qualsevol, fos de la classe que fos, que s'atrevís a proferir la paraula rendició o capitulació. ${ }^{90}$ La ciutat viva moments molt difícils i els morts eren cada cop més nombrosos, a causa de les malalties. Per a no desanimar encara més la població, els metges sol.licitaren que no hi hagués repic de campanes en haver enterrament. ${ }^{91}$

El dia cinc de maig de 1809 , les forces napoleòniques al front del general Reille ocuparen els voltants de Girona. S'inicià el segon setge ${ }^{92}$. Després dels atacs de la torre de Sant Lluís, la de Sant Narcís i la destrucció de la de Sant Joan, entre els mesos de juny i juliol, s'atacà fortament el castell de Montjuïc; els gironins aconseguiren rebutjar aquelles escomeses. ${ }^{93}$ Però la forta pressió dels assetjadors

${ }^{89}$ Val a dir que mesos abans, el general havia hagut de fer el lliurament de la fortalesa de Montjuic a Barcelona, als napoleònics, per ordre del capità general de Catalunya, Ezpeleta. Semblava no gaire disposat a que li tornés a passar el mateix.

${ }^{90}$ PLA I CARGOl, Joaquim. Els setges de Girona, el 1808 i 1809,. Barcelona: Rafael Dalmau editor, 1962, col. Episodis de la Història. p.16.

${ }^{91}$ Vegi's en 1'apèndix documental 3 :Documents relacionats amb els setges, el document $\mathrm{n}^{\circ} 7$.

92 El cinc de juny de 1809 l'ajuntament demana al capítol que es realitzi un ofici de rogativa a Sant Narcís per a que els empari en aquest moment tant crític, d'assetjament per part de l'enemic. Vegi's l'apartat 3.f, en les "Funcions musicals de la capella", en aquest mateix capítol.

${ }^{93}$ El vuit de juliol de 1809 , Te Deum solemne a les onze del matí, per la gloriosa defensa de Monjuïc, fent endarrera l'enemic després de 
al castell produeix el seu abandó definitiu per part dels defensors el deu d'agost; d'aquesta manera s'ensorrava la màxima defensa de la ciutat, $i$ els gironins començaren a sentir el desconhort i la temença de no poder aguantar gaire més temps, si no rebien reforços i ajudes, aviat.

L'arribada d'un important comboi a la ciutat, contrarià als francesos, que no comprenien com una plaça de fortificacions tan migrades podia oferir una resistència tan ferma i llarga. Nous atacs es planejaven. El dinou de setembre es desenvolupà una duríssima i aferrisada lluita que, a part dels bombardejos, va esdevenir un violent cos a cos. Els gironins aconseguiren altra vegada aplacar l'atac, la qual cosa els esperançà. La col-laboració dels eclesiàstics gironins en aquest període de lluites fou extraordinària. ${ }^{94}$

En els dies posteriors el greu problema de l'alimentació creixia, i la debilitat física dels defensors de la ciutat, s'aguditzava. Els possibles queviures que la Junta Superior de Catalunya els havia de fer transmetre i que els podia permetre obligar als assetjants a abandonar la ciutat, no arribaven. Els francesos confiaven ja més en el setge, que en les escomeses. El bloqueig de la comunicació externa de la ciutat, les malalties que assolaven els gironins, i un índex de mortandat esfereïdor, la portaven a un estat d'extenuació total. El general Àlvarez, amb la seva obstinació havia portat la ciutat a un sacrifici inútil. ${ }^{95}$

tres assalts, i dues hores de "función terrible y sangrienta". Vegi's l'apartat 3.f, dintre de les "Funcions musicals de la capella".

${ }^{94}$ Un exemple 1'aporten els germans Illa, que s'allistaren al batalló terç de Miquelets; vegi's l'apartat 1 dins els "Períodes de crisi en el funcionament de la capella" També es deixà que els ciutadans es refugiessin a la catedral, vegi's en l'apèndix documental, Documents relacionats amb els setges, el $\mathrm{n}^{\circ} 10$.

$95 \mathrm{Hi}$ ha estudis sobre la psicologia malaltissa d'aquest general. BELTRANA, P. i RUIZ, D. La locura de Álvarez de Castro. Ensayo sobre la psicología patológica de un episodio heroico. Girona: Imp. Dalmau Carles Pla, 1910. 
La Junta General, després de fortes discussions accepta la capitulació ${ }^{96}$. Al final de set mesos de setge, la ciutat havia perdut la meitat dels seus habitants: la població descendí a uns cinc mil habitants ${ }^{97}$. S'iniciaren llavors quatre anys d'ocupació napoleònica.

Malgrat tot, les posteriors conquestes napoleòniques de les ciutats de Lleida, Tortosa ${ }^{98}$ i Tarragona, no comportaren el control del Principat. L'actuació de les guerrilles foren un autèntic maldecap per als ocupants. Ara bé, la unitat catalana en la lluita, que el clergat formulava en termes de croada, amagava motivacions diverses. Uns lluitaven contra la França revolucionària que representava Napoleó i per refermar els principis i estructures tradicionals; els altres contra aquells, els francesos, qui s'aliaven a una monarquia decadent i que aplicava una política infame i antiquada ${ }^{99}$.

Entre el 1810 i el 1814, l'ocupació francesa travessa diferents etapes. Amb el general Auguerau i l'assessorament

${ }^{96}$ El set de desembre, els representants del govern francès, ordenen al capítol que celebri un Te Deum en acció de gràcies per la presa de la ciutat. Vegi's l'apartat 3.f, dintre de les "Funcions musicals de la capella", en aquest mateix capítol.

${ }^{97}$ Segons Ramon Alberch i Fugueras, Ob.cit. , hi havia 4600 habitants el 1812, en un cens dels francesos. La gent es va anar morint encara, per les malalties i carències ocasionades pels molts mesos de setge a la ciutat, durant el període de 1809-1812. El nivell de destrucció urbana era impressionant.

98 El corregidor ordena un Te Deum per la rendició de Tortosa, el quinze de novembre de 1810. Vegi's l'apartat 3.g, dintre de les "Funcions musicals de la capella".

99 El mestre Rafael Compta, quan escriu en el Llibre de Noms $i$ Cognoms les dades de l'escolà Ramon Serra de la Bisbal, hi afegeix un comentari que diu: Sen aná per temór de su-/frí altre siti dels españols, / y nos virificá./ 
de 1'afrancesat Tomàs Puig ${ }^{100}$, els francesos practiquen una política d'atracció i oficialitzen el català ${ }^{101}$, cosa que no passava des del Decret de Nova Planta. La política practicada no és ben acollida des del govern central i Auguerau és substituït pel general Macdonald, que es preocupà clarament de la imposició militar i practicà una política de francesització encoberta. El 1811 fou rellevat pel general Decaen, qui portà a terme la política napoleònica d'annexió de Catalunya a França, duta a terme pel gener de $1812^{102}$. Es dividí el territori en quatre departaments ${ }^{103}$, s'establí el règim civil francès i l'administració comuna. En aquesta etapa és quan hi ha més col-laboracionisme, tot $\mathrm{i}$ que els casos d'afrancesament són excepcionals. ${ }^{104}$

\footnotetext{
${ }^{100}$ Tomàs Puig (1775-1835) s'adherí a la causa francesa per les seves idees avançades; ocupà els càrrecs de corregidor de Figueres i de Girona, i de president de la Cort d'Apel-lació de Barcelona. Se'1 considera l'inspirador de l'assaig catalanista de 1810 .
}

101 El Diario de Barcelona, publicació fundada el 1792, passà a escriure's en català el 1810 durant un curt període de temps.

102 A Girona, el dos de gener de 1812 va començar a publicar-se la Gazette de Gironne; el primer número és en francès i català, però des del segon número el text és en francès i en castellà. Així ho explica RAHOLA, Carles. La ciutat de Girona. Girona: Ed. Base, 2000, V.II. Reedició en facsímil. p. 36.

${ }^{103}$ Girona és capital del Departament del Ter. Com explica Joan Gay a l'article "Una temporada d'òpera francesa a la Girona Napoleònica", la ciutat es podia considerar l'autèntica capital de la Catalunya ocupada pels francesos i model de la implantació de l'administració napoleònica a Catalunya i del seu sistema fiscal. S'hi instal-laren dos milers de francesos en una ciutat amb uns 4500 gironins. En aquest marc s'explica la implantació de diversos elements de la vida i la cultura franceses en GAY I PUIGBERT, Joan, "Una temporada d'òpera francesa a la Girona napoleònica". Revista de Girona, nº161, (1993) p.54-57.

${ }^{104}$ És el cas del bisbe de Girona Ramírez de Arellano, tot i que ho fou per simple acomodació al nou context, com explica FONTANA, Josep, Història de Catalunya. Barcelona: Edicions 62, 1991, Volum V. p. 172. 
El tretze de novembre de 1813, el Tractat de Valençay, signat secretament d'esquena als anglesos, havia de posar fi a la guerra. La signatura es feu pública l'abril de 1814, i els francesos abandonaren el país. ${ }^{105}$ Amb motiu de la rendició de la cort francesa, se celebren Te Deum a totes les esglésies el dia dos de maig ${ }^{106}$.

Ferran VII tornà a Espanya el mes de març de 1814, entrant per Figueres ${ }^{107}$. Restablí l'antic règim per mitjà d'un cop d'estat, ja que la regència i les corts manifestaren que no reconeixerien al rei, fins que no prestés el jurament previst per la constitució de Cadis. ${ }^{108}$ Pel maig del mateix any l'abolia, i anul-lava les reformes liberals dutes a terme. Es condemnen a presidi els diputats liberals i s'expatrien els afrancesats, instaurant-se de nou l'absolutisme de l'antic règim, en el període de 1814 a 1820. En síntesi, el que pogué significar la Guerra del Francès en quant a desaparició de l'antic règim, quedà en no res, car l'absolutisme imposat per Ferran VII per les armes, feu tornar una societat malmesa pels aconteixements bèllics a les condicions polítiques, socials i econòmiques que imperaven el 1808 .

Després del període d'invasió francesa, els camps havien quedat erms, devastats i reneix el bandolerisme. El

\footnotetext{
${ }^{105}$ Vegi's el peu de pàgina $n^{0} 61$ fent referència al comentari que fa l'organista Antoni Guiu a la seva consueta sobre la marxa dels francesos de la ciutat.

${ }^{106}$ Vegi's l'apartat 3.h dintre de les "Funcions musicals de la capella".

${ }^{107}$ Te Deum, el vint-i-vuit de març de 1815 per celebrar l'entrada del rei a Espanya, un any anterior, el vint-i quatre de març de 1814. Vegi's l'apartat 3.h dintre de les "Funcions musicals de la capella".

${ }^{108}$ Durant els anys d'ocupació napoleònica s'havien aprovat les corts de Cadis (1812), s'havia suprimit la inquisició i fructificaren les idees liberals.
} 
1815 Girona tenia 4551 habitants ${ }^{109}$, la recuperació del pols demogràfic $\mathrm{i}$ econòmic de la ciutat serà un procés llarg $\mathrm{i}$ difícil. De fet, la dominació francesa de la ciutat fou massa curta per a que les transformacions planejades poguessin donar fruits.

Totes les esperances de reforma d'un règim dèspota $\mathrm{i}$ agonitzant se n'anaven en orris, així com les promeses fetes als gironins d'alliberar-los de contribucions durant deu anys en recompensa a la seva lliuta durant els setges. ${ }^{110}$ Els anys de la primera etapa absolutista, són tristos pels gironins, abocats a una ruïna econòmica, sotmesos de nou a les forces de l'antic règim, i demogràficament exhausts. Aquestes són les causes que impediren les transformacions socials i l'avenç econòmic que sí es produí en altres ciutats. ${ }^{111}$

Des del restabliment de la monarquia, no passa any sense conspiració liberal descoberta. El liberalisme avançà per via clandestina entre la burgesia i els militars mentre que al camp, aparegué el moviment reialista ${ }^{112}$, que era absolutista, però oposat alhora al liberalisme i a la centralització.

L'u de gener de 1820, el tinent coronel Rafael Riego se subleva a la localitat gaditana de Cabezas de San Juan

109 BOSCH I PORTELL, Mònica. "Girona, capital d'hisendats", Història de Girona. Girona: Adac, 1991-2000. p. 246.

${ }^{110}$ Probablement fou aquest el motiu pel qual un grup de membres de la capella de música, no s'aixecaren en el Gloria Patri dels Salms, i hagueren de ser amonestats pel capítol. Ll.R.C. 1815-1817, 27 d'abril de 1816, fol. 88. Vegi's també l'apartat 3.h de les "Funcions musicals de la capella".

111 Vegi's CLARA, Josep. Introducció a la Història de Girona. Salt: Edicions El Pèl, 1983.

112 El corrent reialista evolucionat esdevé carlisme, moviment sociopolític de signe antiliberal i antirevolucionari. 
contra l'absolutisme de Ferran VII i proclama la constitució de 1812. S'inicia l'anomenat Trienni Constitucional o Liberal (1820-1823). Ferran VII es veu obligat a jurar la constitució de Cadis el nou de març i nomena el primer govern constitucional l'ú d'abril, format per excondemnats de 1815 .

A Girona, enmig d'un notable desconcert, es proclama la constitució el dotze de $\operatorname{març}^{113}$, després d'un avalot popular impulsat pels oficials de la guarnició i els empleats de l'administració. La preocupació principal per al govern de la ciutat era mantenir l'ordre públic. Com explica Mònica Bosch i Portel1 ${ }^{114}$ el govern liberal proposa tota una sèrie de mesures reformistes, de les quals, les més moderades, foren acceptades $\mathrm{i}$ assumides pels tres primers ajuntaments gironins del trienni: supressió de la Inquisició, desvinculació de patrimonis, reforma fiscal i supressió dels ordres monacals, entre d'altres. En canvi, hi hagué desacord amb les reformes més radicals com la desamortització o l'abolició del mig delme. ${ }^{115}$

El règim liberal tingué una ferma oposició per part dels moviments reialistes, clars antecedents de les guerres carlines, ja que potencià el descontentament en el camp degut a la reforma fiscal que l'afectava directament i a la caiguda dels preus agraris. Girona fou testimoni de la revolta del desembre de 1821, quan un grup de reilaistes entrà per sorpresa a la ciutat per alliberar els seus presos,

\footnotetext{
${ }_{113}$ Te Deum per la publicació de la constitució, el quinze de març de 1820. Vegi's l'apartat 3.i dintre de les "Funcions musicals de la capella".

114 BOSCH I PORTELL, Mònica. "De la restauració absolutista a la revolució liberal" en Història de Girona, Ob.cit,. p. 251.

115 En referència a la precarietat de fons del capítol durant el Trienni, vegi's l'apartat 2 dins els Períodes de crisi en el "Funcionament de la capella".
} 
però sense aconseguir-ho. A Catalunya la situació es complicà de manera vertiginosa i s'arribà a declarar l'estat de guerra, ja que la situació era de veritable conflicte civil. El set d'abril de 1823, l'exèrcit francès dels Cent Mil Fills de Sant Lluís, enviat per la Santa Aliança - Rússia, Prússia, França i Àustria-, travessa la frontera per ajudar els absolutistes. ${ }^{116} \mathrm{~A}$ aquest exèrcit s'hi afegiren els voluntaris reialistes. Entraren a Girona el dos de maig de 1823, sense cap oposició per part de la ciutat. El principal nucli de resistència liberal se situà a Barcelona.

Les capes intermitges de la societat, és a dir, ni nobles ni camperols, foren les grans perdedores en aquesta guerra, que posà fi al Trienni Liberal el 1823 i donà lloc a la segona restauració absolutista.

Amb el retorn de l'absolutisme, la repressió seria més forta que mai. Ferran VII derogà ràpidament tot el que havia legislat el govern liberal i s'obrí la nefasta etapa anomenada Dècada Ominosa, des de l'any 1823 fins al 1833. Molts liberals hagueren d'exiliar-se. Amb la creació de la Junta Provisional Reialista es vetllaria pel restabliment de les coses tal com eren abans del període liberal. Es recuperen antics drets i béns del clergat, com el cobrament del delme, i es crea el Batallón de Voluntarios Realistas amb la missió de defensar el nou règim.

De tota manera, el règim restaurat no sapigué resoldre els problemes del camp que s'arrossegaven d'anys enrera i amb la seva pròpia política nodrí les partides de reialistes agraviats o malcontents, que eren els ultrareialistes o absolutistes més intransigents i que havien

${ }^{116}$ A França s'havia restaurat la monarquia després de l'abdicació de Napoleó el 1814. La societat francesa era dominada pels ultres, que amenaçaven les llibertats. Aquesta situació política explica la nova invasió. Vegi's pel cas l'apartat 3.b, dins de les "Funcions musicals de la capella". 
lluitat per restablir la monarquia absolutista durant el Trienni Liberal. Es produeixen alçaments d'aquests grups precarlins a Girona, Manresa, Vic, Olot i Tarragona; exigien la substitució de Ferran VIIè pel seu germà Carles Maria Isidre. Els dirigents polítics que recolzaven la revolta tenien com a objectiu acabar amb l'actitud del monarca envers el liberalisme que, al seu parer, s'estava tornant massa permissiva. La Guerra dels Malcontents es va desenvolupar a Catalunya entre l'abril i l'octubre de 1827; la primera fase de l'aixecament era un moviment declaradament carlí, però fineix ràpidament, per tornar a renèixer més ben organitzat de mans dels voluntaris reialistes agreujats. Finalment, el moviment fou sotmès durament pel propi règim absolutista..

El comte d'Espagnac, paranoic, actua com a dictador a Catalunya, del 1827 fins al 1832, perseguint els malcontents, els liberals i la burgesia, en una etapa recordada especialment per la implantació d'un règim de terror. La seva posició contrària al reialisme més combatiu va culminar en el seu assassinat, perpetrat pels mateixos correligionaris.

A la mort de Ferran VIIè va esdevenir reina la seva filla Isabel, en virtut de la promulgació de la Pragmàtica Sanció el 1830, impulsada pel propi monarca, que permetia l'accés de les dones al tron. Don Carles Maria Isidre, germà de Ferran VIIè, es considerava i era considerat per alguns sectors de la societat espanyola l'hereu legítim de la corona. Les tensions entre els partidaris de l'Infant Carles i els de la reina Maria Cristina de Borbó, regent, i la seva filla Isabel, desencadenaren la Primera Guerra Carlina. Val a dir que la qüestió dinàstica no explica per ella mateixa el carlisme, però en fou un símbol destacat del moviment. La causa carlista implicà la lluita contra el liberalisme ${ }^{117}$ i el

117 Els règims liberals es caracteritzen per les següents condicions: sobirania popular, monarquia limitada, constitució escrita i parlament electiu. 
manteniment de la tradició. Els punts principals de les proclames eren Déu, la pàtria i el rei. El conflicte enfrontà, segons la interpretació clàssica, els partidaris de l'opció absolutista $^{118}$ representada per l'infant Carles (el clergat, la pagesia i l'aristocràcia) i de la liberal, al voltant d'Isabel II i la seva mare, reina regent (la burgesia, la menestralia i el proletariat).

Girona $^{119}$ es mantingué fidel a Isabel II i la seva proclamació es féu l'ú de desembre de 1833 i se celebrà un Te Deum. ${ }^{120}$ L'ajuntament de Girona es caracteritzà per un extremat moderantisme durant aquests anys, i apostà pel sistema de "justo medio" que establia l'Estatut Reial (text polític compost de 50 articles que tracten de la composició, funcionament $i$ competència de les corts) $i$ que fou promulgat per la reina regent Maria Cristina, en nom d'Isabel II. A nivell general, aquest sistema no acontentà ningú i per l'agost de 1836, s'obligà la reina a restablir la Constitució de Cadis.

Per mantenir ordre a la ciutat, l'ajuntament recorria a les obres públiques o el control estrictre del preu i la qualitat del pa; els avalots populars anomenats

118 La direcció del carlisme va aconseguir aixoplugar sota un antiliberalisme, que no defensava l'antic règim sinó una altra manera de transformar el feudalisme, sectors poc homogenis de camperols $\mathrm{i}$ treballadors urbans.

${ }^{119}$ El territori nacional és dividit en províncies aquest any. Girona haurà estat vegueria fins al Decret de Nova Planta i corregiment fins al 1833, a més de cap de Departament durant l'ocupació francesa.

${ }^{120}$ Vegi's l'apartat 3.1 dins de les "Funcions musicals de la capella". 
Bullangues ${ }^{121}$ de 1835 i 1836 , no tingueren cap repercussió violenta a Girona. ${ }^{122}$

El dinou de febrer de 1836, Mendizábal, pocs mesos després d'ocupar el càrrec de Jefe del Consejo de Ministros, publica el seu decret desamortitzador on s'hi disposa una sèrie de mesures que afecten fonamentalment el clergat regular. Seran desamortitzats els bens eclesiàstics i posats posteriorment a la venda en pública subhasta. El govern pretenia amortitzar en part el capital del deute públic i obrir l'accés de la burgesia a la propietat. ${ }^{123}$

El vuit de juny de 1837 , en plena Guerra Carlina, es promulga una constitució progressista, presentada com una revisió de la de Càdis. Seguint amb la política desamortitzadora, el vint-i-nou de juliol de 1837, un decret d'expropiació dels béns del clergat secular amplia la base de la desamortització de les propietats eclesiàstiques i al mateix temps, posa fi a la facultat de l'església de rebre contribucions de forma directa.

Espartero, un dels caps més representatius del partit progressista, va captar-se l'ala més moderada de l'exèrcit carlí i, el 1839, aconseguí que el general Maroto signés el conveni de Vergara ${ }^{124}$, amb el qual es reconeixien els graus

\footnotetext{
${ }^{121}$ Aquests avalots populars produïts en el marc de la revolució liberal entre 1835 i 1843, tingueren molta significació a Barcelona.

${ }^{122}$ En aquesta mateixa línia devia actuar l'ajuntament, en demanar al mestre Josep Barba que muntés funcions operístiques a la ciutat, en motiu d'haver-s'hi instalat una companyia italiana, sobretot tenint en compte el gran interès que l'òpera despertava en els ciutadans. Sembla que hi havia una intenció d'aplacar possibles brots insurgents.

${ }^{123}$ En els llibres de resolucions capitulars, hi ha diverses proves de desamortitzacions de vivendes que eren propietat del capítol. Per conèixer en detall com afecten aquestes polítiques als integrants de la capella, vegi's l'apartat 3 els "Períodes de crisi".

${ }^{124}$ Els carlins catalans, no reconegueren el conveni.
} 
militars carlins i un cert respecte als furs. La primera Guerra carlina acabà definitivament el maig de 1840, quan el darrer reducte de resistència de Catalunya, dirigit per Cabrera, és reduït.

El 1840, la reina governadora abdica després de la Crisi dels Ajuntaments ${ }^{125}$. En el moment que Espartero fou nomenat regent del regne, a Girona es creà una gran tensió. De fet, es produïren aixecaments en contra del govern progressista per part de les masses populars, tot $\mathrm{i}$ que l'ajuntament i les autoritats provincials es mantingueren al costat d'Espartero. Es creà la Junta Central de Vigilància de la Província de Girona per a recolzar el govern progressista. O'Donnell intentà restablir la regència de Maria Cristina en un pronunciament moderat, però fracassà.

El tretze de novembre de 1842, les revoltes a Barcelona ${ }^{126}$ contra la política 1liure-canvista d'Espartero, que amenaçava la indústria catalana foren reduïdes militarment de forma molt dura, fins $i$ tot s'arribà a bombardejar la ciutat. A Girona es visqueren moments de molta tensió, quan arribaren les notícies del que estava passant a Barcelona.

A començaments de 1843, Espartero disol les corts i convoca eleccions, presionat per les fortes crítiques propiciades per l'actuació militar a Barcelona. Les noves

${ }^{125}$ Com explica Josep Fontana a la Història de Catalunya, (Ob.cit.), el partit moderat pretenia imposar un nou sistema de designació a dit d'alcaldes entre els regidors elegits i de caps de partit. Una llei com aquesta prenia als progressites l'únic terreny on encara tenien possibilitats d'actuar el control de les corts, per la via indirecta dels ajuntaments i les diputacions. A això cal sumar-hi el règim dictatorial que sofrí Catalunya des de 1837. És a Barcelona on les confrontacions adquireixen una importància destacable.

${ }^{126}$ Aquestes revoltes foren secundades obertament a Girona del vint al vint-i-dos de novembre de 1842 . 
corts, dividides en múltiples faccions, també foren disoltes pel maig, al mateix temps que presentaven al regent la dimissió del govern. ${ }^{127}$

El sis de juny de 1843, després de múltiples aixecaments per tot l'estat, es creà una Junta Suprema Provisional de govern de la Província de Barcelona, que defensava la convocatòria a Madrid d'una junta central amb representants de totes les juntes provincials creades al llarg del moviment i que hauria de dur a terme un seguit de reivindicacions que des de la Constitució de 1837, s'havien anat ajornant. Narváez, González Bravo i Serrano, accepten les condicions, mentre preparen la formació d'un govern provisional. Exil-liat Espartero, el trenta de juliol de $1843^{128}$, degut als nombrosos errors comesos i amb l'entrada a Madrid de les tropes comandades pels generals Serrano, Narváez i Aspiroz, el govern quedà format per una extranya coalició; els seus membres eren J.M. López, González Bravo, Serrano, Prim i Narváez. Contràriament al que s'havia promès a Barcelona, aquest govern no convocà la Junta Central. Aquest fet desencadenà la insurrecció centralista. La ciutat de Girona es pronuncià a favor del moviment.

Davant la manca de resposta per part del govern, el dos de setembre de 1843 s'inicià la revolta a Barcelona, anomenada la Jamància, i dos dies després a Girona es veia un cert moviment a favor de secundar la sublevació ${ }^{129}$.

\footnotetext{
${ }^{127}$ La complexitat política és molt elevada, dintre dels progressistes hi ha els que s'oposen a Espartero, i els que en són partidaris.

128 Te Deum el trenta de juliol de 1843, per celebrar el "Glorioso Pronunciamiento". Vegi's l'apartat 3.m dins de les "Funcions musicals de la capella".

${ }^{129}$ Aquesta revolta coincidí amb un terrible aiguat, els dies 18 i 19 de setembre de 1843 , que provocà moltes pèrdues humanes i materials al barri de Sant Pere, ja que es desbordà el riu Galligans.
} 
Entre l'ú d'octubre i el set de novembre, Girona fou assetjada per les tropes del general Prim, que arribaren a bombardejar-la per tal d'aconseguir la seva rendició. El nou de novembre, Prim entra a la ciutat i s'inhabiliten els membres de l'ajuntament que havien restat a la ciutat durant la revolta. Hi hagueren represàlies, exilis i empresonaments. ${ }^{130}$

L'ú de desembre de 1843, Girona celebra l'acte de proclamació d'Isabel II com a reina d'Espanya ${ }^{131}$. L'ajuntament agraí a la corona la seva posició en el control de la revolució.

Amb aquests fets, s'imposà una política de retorn a l'ordre en el període conegut com a Dècada Moderada de 1844 a 1854. Es creà la Guàrdia Civil (1844) i la Guàrdia Rural (1849), desapregué la Milícia Nacional ${ }^{132}$, es reduí el dret de vot a molt pocs ciutadans, $i$ els candidats a ser elegits eren mínims ${ }^{133}$. La Constitució de 1845 era més conservadora que la de 1837. El tres d'abril de 1845, es retornen al clergat les seves propietats no venudes, i es fixa una dotació que possibiliti el manteniment de les activitats eclesiàstiques.

${ }^{130}$ Se celebrà un Te Deum el dotze de novembre de 1843, segons BOSCH I PORTELL, Mònica. "De la regència d'Espartero al segon periode de govern moderat”, Ob. cit, p. 258. A les actes capitulars, no hi consta.

131 S'interpreta un Te Deum el dos de desembre de 1843, per la proclamació d'Isabel II com a "Reina Constitucional". Vegi's 1'apartat 3.1 dins de les Funcions musicals de la capella.

${ }^{132}$ Cos associat a la instauració del règim liberal, però que s'havia manifestat "perillós" en moments crítics.

${ }^{133}$ A les eleccions de 1849 a Girona, només tres-cents divuit veïns de la ciutat tenien dret a votar els membres del consistori. 
El darrer esdeveniment històricament important de la primera meitat del segle XIX, és la Segona Guerra carlina o dels Matiners, que va començar el setembre de 1846 i es perllongà fins el maig de 1849 . Les causes que permeteren tal durada, es troben en les condicions socials i econòmiques que patia Catalunya ${ }^{134}$. Hi havia una important crisi de subsistència, com l'escassetat de gra, patates, i un seguit de males collites, a més de la crisi del comerç i la indústria de l'any 1848, especialment en el sector del suro i el cotó. Molts treballadors esdevinguts a la misèria, nodriren les bases carlines. En definitiva, la crisi econòmica de 1846 a 1848 facilità el manteniment i el caràcter accidentalment carlí de la lluita.

${ }^{134}$ Les causes són diverses i no es troben només en el problema successori com oferien els plantejaments historiogràfics tradicionals. 


\section{CAPÍTOL II}

\section{LA CAPELLA DE MÚSICA DE LA CATEDRAL DE GIRONA DURANT LA PRIMERA MEITAT DEL SEGLE XIX}




\section{COMPOSICIÓ GENERAL DE LA CAPELLA}

\section{EL NOMBRE D'INTEGRANTS}

La capella de música de la catedral de Girona, estava constituïda per vint-i-cinc membres. Aquests integrants eren el mestre de capella, membre cabdal; els quatre xantres, principals entonadors del cant litúrgic, tant si era cant pla com polifonia, que solien tenir veu de baix i també participaven en la interpretació de les obres religioses que requerissin la seva presència; dos tenors i dos contralts, que també participaven del cant litúrgic i del religiós; quatre instrumentistes de violí; dos de viola; dos de trompa; tres instrumentistes de vent-fusta, que havien d'ésser hàbils amb la flauta, el fagot i l'oboè ; un contrabaixista ; l'organista i quatre escolans de cor.

A la catedral també hi havia altres persones molt vinculades amb la capella, però que no en formaven part. D'una banda els comissaris de música, que eren dos canonges del capítol. Aquests eren nomenats per períodes de dos anys, i vetllaven pel bon funcionament de la capella de música. Eren els mitjancers entre els músics de la capella i el capítol, i s'encarregaven entre altres coses de fer complir les Ordinacions ${ }^{135}$, o estatuts de la capella, a músics i cantors. A la catedral hi havia també dues persones vinculades amb el funcionament dels orgues, el manxador $\mathrm{i}$

${ }^{135}$ Les Ordinacions eren el reglament que havien de seguir tots els integrants de la capella. Durant el segle XIX es regiren per les Ordinacions del 1735, que constaven de quaranta-vuit punts o ítems, on hi havia reflexats diversos aspectes del funcionament de la capella. Els músics de l'època estudiada, demanaren moltes vegades que es reformessin aquestes Ordinacions, adaptant-les a les circumstàncies dels nous temps (sobretot a partir del 1833), però aquesta reforma mai no es dugué a terme. 
l'orguener, que s'encarregava d'afinar i arranjar els quatre orgues que en aquell moment hi havia ${ }^{136}$.

En l'anterior descripció dels membres que formaven part de la capella de música, hi he inclòs els quatre escolans i l'organista. A través dels documents consultats, sabem que el capítol no els considerava com a integrants de la capella, doncs en els Llibres d'Obra, juntament amb el manxador i l'orguener, entren sempre en un apartat de despeses diferent del de la resta de músics. Tot i això, quan en aquest estudi em refereixi als músics de la capella o parli dels músics en general, sempre hi inclouré els quatre escolans i l'organista, ja que la seva funció va estretament lligada a la resta d'integrants i la música que es feia a la catedral.

Tots els músics cobraven un salari fix anual, anomenat pensió. Els músics seglars eren instrumentistes professionals de Girona i rodalies que treballaven a la capella. Els músics que eren clergues, residien a la catedral i solien pertànyer a la comunitat de beneficiats, els seus drets i deures venien determinats pel benefici que tenien atorgat. Els sous variaven en funció de l'habilitat i el renom del músic, i també de la importància que el capítol donés a la tasca a desenvolupar. Això feia que en algunes èpoques l'organista cobrés més que el mestre de capella, $\mathrm{i}$ viceversa. Músics seglars i clergues, cobraven el salari d'un any en tres pagues, és a dir, per terces. Les terces vencien l'últim dia de setembre, l'últim dia de gener i l'últim dia de maig. ${ }^{137}$

\footnotetext{
${ }^{136}$ Els quatre orgues de la catedral de Girona eren : l'orgue major o orgue gran, l'orgue de la capella de l'Esperança, l'orgue de semidobles i l'orguenet portàtil.

137 Hi ha molts exemples de cobrament de sou, en qualsevol dels llibres d'obra citats.
} 


\section{ELS MÚSICS CLERGUES BENEFICIATS}

Dels vint-i-cinc músics que componien la capella, quinze eren clergues. Músics clergues eren, el mestre de capella, els quatre xantres, els quatre cantors, dos dels violinistes, un dels instrumentistes de viola, i dos dels instrumentistes de vent-fusta. També era clergue l'organista. La majoria d'aquests músics provenien de l'escolania de la catedral o d'altres escolanies, i optaven a la plaça mitjançant una oposició pública bastant rigorosa, tret de comptades excepcions. A tothom li interessava que el cantor o instrumentista en qüestió complís bé la seva tasca, atès que hi anava el prestigi de la catedral.

La qüestió de les places és un xic complexa, ja que cada plaça solia tenir associat un benefici, que moltes vegades prenia el nom de la plaça. Així per exemple la plaça d'un dels tenors, tenia annexat el benefici Segon de St. Vicenç. Molts dels beneficis tenien dos-cents i tres-cents anys d'antiguitat, i havien estat erigits a perpetuïtat per assegurar que la persona que ocupés aquell benefici pogués rebre unes rendes anualment, i no desaparegués la tasca a realitzar. Cada benefici constava d'un ofici sagrat o eclesiàstic, i comportava unes obligacions amb la comunitat. Així doncs, el beneficiat havia de dir un determinat nombre de misses l'any, realitzar tasques per a la comunitat eclesiàstica, per exemple aiguader, o porter, i complir amb el càrrec musical annex.

Els beneficis quedaven lliures per la renúncia escrita o el traspàs del beneficiat, i llavors es convocaven oposicions per a la plaça annexa. Per poder optar a una plaça, els aspirants havien de ser clergues. Si ja havien estat ordenats sacerdots, immediatament després de guanyar l'oposició, podien prendre possessió del benefici. Quan, per la seva joventut, encara no havien estat ordenats sacerdots, 
ocupaven la plaça interinament cobrant una petita pensió, ja que fins que no eren sacerdots no podien obtenir el benefici.

La comunitat de beneficiats estava integrada per un gran nombre d'individus que residien a la catedral, i els beneficiats que formaven part de la capella de música en constituïen una petita porció. Tots ells cobraven un sou per terces i dues lliures de pa diàries. Cal dir també que, per als membres de la capella, tenia prioritat el complir amb les funcions musicals, més que no pas amb les obligacions que comportava el benefici.

En la resolució capitular del cinc d'octubre de l'any $1804^{138}$, apareix que hi havia dotze beneficis aplicats a la capella de música ${ }^{139}$. És interessant el fet que aquest mateix dia es creés el benefici de l'organista, que fins ara mai havia existit. El crearen perquè el sou que el capítol pagava per ocupar la plaça d'organista, havia quedat petit, i els era impossible aconseguir un organista de renom. Per tant, el que fan és annexar a l'ofici d'organista el benefici anomenat segon de la Sta. Creu. Qui obtenia aquest benefici tenia dret a percebre una part de la collita del mas Jordi de Sarrià. Aquesta anècdota és important, en el sentit que amb l'arribada del nou segle, la figura de l'organista és objecte de revalorització, fet que podia tenir a veure amb un cert canvi dels gustos musicals de l'època.

\footnotetext{
${ }^{138}$ Ll.R.C. 1803-1807, 5 d'octubre de 1804.

139 A l'arxiu catedralici hi ha un petit document solt, dins els llibres de la comunitat de beneficiats, de mida $1 / 4$ fol. apaisat, datat el set d'octubre de l'any 1706, en què apareix una menció als dotze beneficis de la capella de música. Per tant aquests dotze beneficis, dels que tantes vegades es fa al·lusió en la documentació del s.XIX, tenen una existència mínima de cent anys.
} 


\section{a) Els beneficis}

Amb la recollida de la informació pertanyent als cinquanta anys estudiats, he anat poc a poc trobant els noms de cada un dels beneficis i l'instrument o funció als quals anaven lligats:

Els xantres, tenien annexats els beneficis següents: Primer benefici de Sta. Anastàssia, benefici Setè de St. Vicenç o els Dolors anomenat dormitorer, benefici de St. Andreu i Quart benefici de Sta. Anastàssia.

Els tenors, el benefici Vuitè de St. Vicenç o els Dolors, anomenat coch, coco o porter i el benefici Segon de St. Vicenç o els Dolors .

Els contralts, el benefici de St. Rafael i el benefici Onzè de St. Vicenç o els Dolors, anomenat manats del Capitol.

Els violins, el benefici Novè de St. Vicenç $i$ els Dolors, aplicat al primer violí, i el benefici de St. Rafael aplicat al segon violí, amb obligació d'alfuller.

Les violes, el benefici per invocació dels àngels $S t$. Rafael $i$ St. Gabriel, aplicat a la viola, amb obligació d'alfuller.

Els instruments de vent, el benefici Segon de St. Pere $i$ St. Pau, aplicat al fagot, la flauta i l'oboè baix, amb obligació d'alfuller i el benefici Tercer de St. Pere i St. Pau, aplicat al fagot, la flauta i l'oboè baix, amb obligació d'alfuller

L'organista, el benefici Segon de la Sta. Creu. 
L'anterior enumeració de places amb el benefici corresponent, és útil en el sentit que moltes vegades, la documentació consultada es refereix als músics pel benefici que ocupaven, més que no pas pel nom.

\section{b) Canvis en els beneficis}

Cal fer esment que el mestre de capella i l'organista, no tingueren un benefici fix durant el període de temps estudiat. En el cas de l'organista, ja hem esmentat que el benefici annex fou atorgat l'any $1804 \mathrm{i}$ era el Segon de la Sta. Creu. Aquest benefici provenia de Josep Serrat, instrumentista de viola, i passà al nou organista Antoni Guiu.

La funció de mestre de capella tampoc tingué un benefici fix, $i$ anaven atorgant a cada mestre el benefici que en aquell moment estava vacant. Per exemple, el benefici Quart de la Capella de St. Dalmau i St. Jordi, passà al mestre de capella Rafael Compta. Aquest benefici provenia de Marià Albert, organista $\mathrm{d}^{\prime} \mathrm{Amer}^{140}$ que, tot i no residir a la catedral, no volgué renunciar mai al benefici que obtenia de la capella de música. Quan morí, el quinze de novembre de 1810, pogueren atorgar al mestre Compta aquest benefici.

Al mestre de capella Honorat Verdaguer li atorguen la collació del benefici Segon de St. Pere i St. Pau, el deu de febrer del 1817. Aquest benefici havia quedat vacant per la renúncia de Narcís Vivern, músic, que havia estat instrumentista de vent i alfuller durant els anys 1795-1816.

${ }^{140}$ Ll.R.C. 1803-1807, 6 de juliol de 1805. 
Finalment, l'any 1829 donen el benefici que tenia el mestre de capella Rafael Compta, mort l'any 1815, al prevere Narcís Sunyer, que no és músic, amb la condició que no afecti els drets passius dels escolans de cor.

\section{ELS MÚSICS SEGLARS PERTANYENTS A LA CAPELLA}

Els músics laics o seglars eren requerits a la capella per a tocar instruments, que en la Girona del segle XIX, eren d'exercici poc freqüent entre els instrumentistes clergues, com ara la trompa, el contrabaix, l'oboè, les xeremies o el sacabutx. La seu gironina també tenia contractats, però, dos instrumentistes seglars de violí, el primer i el segon violí, que foren incorporats a la capella de música per la seva gran habilitat. Algunes vegades passaven a ser primer viola laics, segons convingués.

Els músics laics cobraven una pensió anual, en terces, per tot el que eren les funcions ordinàries. Les funcions extraordinàries, tant si eren dins com fora de l'església, les cobraven a part, també per terces, segons el nombre de funcions realitzades. Així, i a tall d'exemple, transcric a continuació un document on queda palès el cobrament d'una sèrie de funcions extraordinàries, als tres germans Illa $^{141}$ :

\footnotetext{
${ }^{141}$ En aquesta època l'escriptura del català no estava estandaritzada, i és curiós constatar com els quatre germans Illa s'havien posat d'acord i utilitzava un tipus de $i$ diferent en el seu nom, la llatina, la grega, la grega amb dièresi i començant el nom amb hac.
} 
Als 12 de setembre de 1814 tinch pagat àl Pere, Anton, y Narcis Ylla Musicos por/ 9 actos de Capella desde corpus fins a las oposicions de las 2 sochantrias $25 l l 6 s 3$ $25 l l 6$ s 3 / Vera Pedro Hilla. ${ }^{142}$

En èpoques de crisi econòmica, els primers músics que despatxaven eren els laics, que deixaven de percebre la pensió anual i passaven a cobrar per cada acte puntual en què eren cridats. Així, per a cada funció amb tota la música se'ls donava onze sous amb tres diners, i per cada funció amb cors, set sous i sis diners, a cada ú ${ }^{143}$. Si la crisi era molt important acomiadaven també els beneficiats instrumentistes. Els tercers en deixar de percebre la pensió anual eren el mestre de capella i els quatre escolans de cor, seguits dels alfullers. Els últims eren els xantres i l'organista -amb el manxador-; d'aquesta manera podien preservar el cant litúrgic i l'orgue podia suplir, en certa mesura, la resta d'instruments.

\section{ELS MÚSICS COL·LABORADORS}

Atès que la capella de música era molt nombrosa, només en ocasions molt concretes el capítol demanà la col·laboració de músics externs a la capella.

La primera vegada que consta la collaboració d'un músic de fora, és l'any 1804. Després del traspàs de l'organista Josep Prat, el capítol convoca oposició per a cobrir la plaça. Nomena com a examinadors el mestre Rafael Compta i el tenor Bernat Bertran, però necessita un tercer membre que sigui organista. Per evitar les despeses

$\overline{142 \text { Ll.C.O. 1813-1815, fol. } 147 .}$

${ }^{143}$ Ll.R.C. 1823-25, 14 de novembre de 1823, fol. $34 \mathrm{v}$. 
provocades pels desplaçaments i l'estància d'un organista de fora la ciutat, avisen l'organista de Sant Daniel, Miquel Massip. En el segon document transcrit es comprova que el consideraven el millor organista de Girona. Mitjançant aquestes oposicions obtindria la plaça l'organista Antoni Guiu. ${ }^{144}$

Item . $[\ldots] /$

Res. [...] Que para examinadores podrian nombrarsel de la Iglesia el Maestro de Capilla $y$ el R. Bernardo/ Bertran, y para ahorrar gastos el nombramiento/ de un tercer examinador Organista podria hacer-/se en el que lo es de $S .^{n}$ Daniel estramuros de estal Ciudad: pero respecto de $q .{ }^{e}$ han de correr antes los/Edictos hay suficiente tiempo para $q^{e}$ se arregle este/ punto. ${ }^{145}$

It. El S. ${ }^{\text {or }}$ Junca $y$ el $S^{\text {or }}$ Perez Campos propusieron,/ que se acordase definitivamente sobre un tercero/ examinador Organista para la oposicion, que se ha del hacer à la Plaza $\hat{u}$ oficio de Organo vacante, luego que ha-lyan concluido los Edictos./

Res. Que traer un Organista de Barna para los fines ex/presados seria de mucho gasto, $y$ podria tal vez suceder/ el caso de que no se proveyese el organo, y en este caso/ debiendo quedar avierto el concurso seria grave in/conveniente el que permaneciese aqui, ô que regre-/sase à su destino. Por estos motivos se puede he-/char mano de uno de Gerona, el que

\footnotetext{
${ }^{144}$ Tota la informació referent a l'oposició de Guiu és al capítol III.

${ }^{145}$ Ll.R.C. 1803-1807, 5 d'octubre de 1814, fol. 115.
} 
sea mas ha-/bil e inteligente; y parece q. ${ }^{e}$ para el caso serial el Org. ${ }^{\text {ta }}$ de S. ${ }^{n}$ Daniel. ${ }^{146}$

La segona vegada que el capítol requereix la collaboració de músics de fora de la capella és el tretze d'abril de l'any 1810 , la ciutat ha patit el setges de $1808 \mathrm{i}$ 1809, i està ocupada per les tropes franceses. Molts músics de la capella han marxat als seus llocs d'origen i altres són al front. ${ }^{147}$ El capítol, per tal de poder realitzar les funcions musicals de Setmana Santa amb certa dignitat demana als canonges comissaris que cerquin el nombre de músics necessaris, ja siguin de la capella o no.

El tercer document referit a la col-laboració d'un músic de fora, és de l'any 1830 . S'ha realitzat el canvi d'ubicació de l'orgue $\operatorname{gran}^{148}$ i un importantíssim arranjament, pel que els membres capitulars acorden buscar un bon organista que provi l'orgue i doni la seva opinió sobre els canvis realitzats. Avisen l'organista de la catedral de Barcelona Mateu Ferrer, conegut com a Mateuet.

Los Comisionados del Organo dijeron, que el organista de la Cathe-/dral de Barna havia ofrecido venir â revisar, y juzgar la obra del este Organo para lo que le invitaron, como el mejor organista del la Provincia de Cataluña./ Res. ${ }^{\text {on }}$ enterado el Cabildo aprueba esta eleccion. ${ }^{149}$

\footnotetext{
${ }^{146}$ Ll.R.C. 1803-1807, 13 d'octubre de 1814, fol. 119v.

${ }^{147}$ Els germans Illa són al Batalló Terç de Girona des de principis de l'any 1809. Ll.R.C. 1807-1812, 28 de gener de 1809, fol. 182.

${ }^{148}$ Aquest fet s'estudia de forma detallada, en l'apartat de l'orgue que hi ha en aquest mateix capítol.

${ }^{149}$ Ll.R.C. 1829-1831, 12 de març de 1830, fol. 20v.
} 
El citat organista concorregué a Girona i emeté un dictamen escrit amb la seva opinió de la reforma de l'orgue, tot recomanant alguns canvis per millorar-ne la sonoritat. ${ }^{150}$

${ }^{150}$ Aquest document es troba transcrit en l'apartat de l'orgue, dins aquest mateix capítol. 


\section{PAUTES DE FUNCIONAMENT DE LA CAPELLA}

\section{LES ORDINACIONS}

Durant la meitat de segle que ens ocupa, fou constant la referència a les Ordinacions de la Capella de l'any 1735. Sempre que sorgia algun dubte o problema eren consultades, proporcionant la pauta de funcionament; eren el que ara denominaríem el reglament de règim intern. Aquestes ordinacions constaven de quaranta-vuit punts que es referien a la normativa general dels músics, així com les obligacions referides a càrrecs concrets.

Les ordinacions del 1735, tracten de forma clara el tema de les jerarquies de la capella de música. Com que entre els músics moltes vegades hi havia malentesos $\mathrm{i}$ disputes, en els llibres d'actes capitulars apareixen tot sovint referències directes a aquestes ordinacions. Però anem a veure com s'organitzava la jerarquia de les persones que, a la seu, tenien una relació directa o indirecta amb el fet musical.

En primer 1loc, i per sobre de la capella de música, hi havia el capítol dels canonges que, sota consell del bisbe es reunien amb certa periodicitat. El capítol era l'únic organisme que podia convocar oposicions, amonestar $\mathrm{i}$ fins $\mathrm{i}$ tot destituir algun músic de la seva plaça.

En segon 1loc, tenim els comissaris de música. Aquests eren dos canonges del capítol, escollits per un període de dos anys per tal de tractar les qüestions acordades pel capítol, més directament amb la capella; 
també feien arribar les peticions dels músics al capítol. Eren els mitjancers entre el capítol i la capella. Normalment els comissaris de música, havien format part d'alguna capella en anys anteriors, o tenien una certa sensibilitat musical. Prova d'això n'és el canonge Francesc Juncà i Carol, mestre de capella de gran renom, qui fou durant molts anys comissari de música de la catedral de Girona.

En tercer lloc hi havia el mestre de capella, que era l'encarregat de composar la música nova, de decidir les composicions que es tocarien, de dirigir la capella en les funcions, de dirigir els assajos i ocupar-se dels minyons de cor.

En quart lloc hi havia l'organista que, a més de tocar l'orgue, feia les funcions de mestre quan aquest no hi era.

Per a qüestions del cor també eren importants els xantres, doncs eren els encarregats de "sostenir l'entonació del cor" sobretot en el cant litúrgic; en certa forma n'eren els directors i vetllaven pel bon funcionament d'aquest cant.

El primer violí clergue, també tenia una certa importància per a les qüestions instrumentals, sobretot si faltaven el mestre de capella i l'organista.

En darrer terme, tenim la resta de músics i cantors, tant si eren clergues com seglars.

Les quaranta-vuit ordinacions de l'any 1735, es troben transcrites per el Dr. Jordi Rifé, en l'interessant article sobre les ordinacions de la capella de música de la 
catedral de Girona, publicat l'any $1987^{151}$. Com que aquestes ordinacions foren de gran vigència durant el segle XIX, m'ha semblat interessant realitzar un petit resum amb el corresponent comentari, de les que tingueren més trascendència durant el segle estudiat.

La primera ordinació ens diu l'objectiu principal de la capella de música, i al mateix temps ens deixa clar el paper cabdal que suposa la figura del mestre de capella.

1- La principal tasca de la capella és la contribució a l'esplendor de les funcions de l'Església, procurant desenvolupar la seva tasca el millor que puguin, tenint cura de l'harmonia entre els individus de la mateixa; en cas d'algun disturbi el mestre de capella actuarà de moderador, si no ho aconsegueix es recorrerà als comissaris de música.

Atenent a que un gran nombre dels músics de la capella eren clergues, a l'ordinació segona, podem veure el que és moralment correcte per a un músic de la catedral.

2- Per conservar la decència de la capella, els músics s'abstindran de tocar en saraus, balls i altres indecens.

Un exemple il·lustratiu de l'aplicació de l'anterior ordinació, fou el rebombori que es mogué a la catedral, quan el mestre Barba l'any 1847 dirigí els assajos de

151 RIFÉ I SANTALÓ, Jordi. "Les ordinaciones de la capella de música de la Catedral de Girona. Any 1735", Recerca Musicològica, VI-VII (1986-1987), p. 149-171. 
l'orquestra d'una companyia d'òpera italiana, que en aquell moment feia representacions a la ciutat. ${ }^{152}$

L'ordinació cinquena ha resultat molt important per al present estudi, doncs cada vegada que un músic volia sortir de la catedral havia de demanar permís als comissaris de música, llavors aquests passaven la petició al capítol de canonges, que es reunia un cop per setmana. És gràcies a aquests memorials apareguts en les actes, que hem pogut esbrinar la funció que realitzaven molts dels individus de la capella de música.

5- Cap individu es podrà absentar sense el permís dels comissaris de música.

El punt sisè, fou objecte de conflicte a partir de les desamortitzacions del 1833. El poder econòmic de l'església havia baixat considerablement, i moltes vegades els músics no podien cobrar. Davant aquesta situació cinc membres de la capella, sol-licitaren poder constituirse en grup musical, per poder actuar en altres esglésies a un cost més reduït del que suposava dur tota la capella, i d'aquesta manera guanyar-se un sobresou. El capítol no hi accedí, ja que aquesta proposta anava en contra del punt sisè de les ordinacions; a més, els canonges consideraren que s'estaria donant un privilegi a uns músics determinats. ${ }^{153}$

6- Cal saber que no els és permès cantar o tocar instruments en cap altra església sense

152 Per a més informació vegi’s el mestre Josep Barba, en el capítol III.

153 La proposta dels músics i les circumstàncies que l'envoltaren, estan recollides dins aquest mateix capítol, en l'apartat de les grans desamortitzacions. 
el mestre, o la seva autorització, sota pena de deu sous.

Hi ha tot un grup d'ordinacions que es refereixen a les pautes generals del funcionament de la capella, com ara la puntualitat, l'obediència al mestre, l'obligatorietat d'assistir als actes i la participació sempre conjunta. Aquestes ordinacions són la tercera, la quarta, la sisena, la setena, la novena, la dissetena i la divuitena.

3- Tots els individus han d'assistir puntuals sempre que se'ls convoqui, també als assajos.

4- Hauran d'acceptar el paper que el mestre els doni; si no hi estan d'acord es podran queixar als comissaris de música. En cas de desobediència al mestre, "contrafacció", pagaran una multa de deu sous.

7- Pels integrants de la capella que són beneficiats, serà prioritària la seva tasca com a músics, que no pas les obligacions o altres ministeris que comporti el seu benefici.

9- El mestre està obligat a valer-se dels individus de la capella per a qualsevol funció dins o fora de l'església.

17- Per major lluïment de la capella, provarà la música nova, i repartirà els papers entre els músics com ell consideri convenient.

18- Contribuïrà al lluïment de la capella, que els individus explotin les seves 
habilitats, encara que no siguin les que els permeteren l'ingrés al cos.

Les ordinacions vuitena, setzena i vint-i-unena es refereixen molt específicament a les obligacions que tenia el mestre de capella, pel que he trobat més convenient comentar-les en el capítol tercer, referent als integrants de la capella.

Les ordinacions dinovena i vintena són referides als músics que no formen part de la capella. Generalment, no podien tocar amb la capella músics que no hi pertanyessin. Malgrat tot, en algunes ocasions i en motiu de diades molt excepcionals (com la visita del rei), el capítol contractava cobles de xirimies $i$ altres instrumentistes de la ciutat i rodalies, per a donar més solemnitat a la diada. En tot cas, els músics els havia d'avisar el capítol o els canonges comissaris de música, mai el mestre de capella.

19- Sota cap circumstància podrà, el mestre, admetre músic estrany, només ho podrà fer amb el permís dels comissaris, els quals atenent la urgència $\mathrm{i}$ l'habilitat del foraster, resoldran si haurà d'ésser cridat $\mathrm{i}$ el salari què tindrà.

20- Qui pagui la festa pot elegir els instruments, però no els músics; encara que volgués la presència d'algun músic en especial de fora de la capella, no seria possible.

L'ordinació vint-i-dosena es refereix als individus més indicats per a dirigir la capella de música.

22- Si falta el mestre, dirigirà el mestre jubilat (si n'hi ha), si no l'organista; en cas 
que tampoc hi fos, els comissaris dirien qui ha de dirigir la capella.

De l'ordinació vint-i-tresena a la trentena s'estipulen el sous corresponents a cada funció. Pel que fa aquestes ordinacions és interessant constatar que els sous no canviaren en quasi cent anys. Tenint en compte que les ordinacions s'instauraren el 1735, hem trobat dades que ens indiquen que l'any 1823 se seguien pagant onze lliures quatre diners per a cada acte amb tota la capella ${ }^{154}$. Seria interessant veure si el nivell adquisitiu d'un músic amb onze lliures, era el mateix el 1735 que el 1823.

23- Per a que tothom sàpiga els guanys que comporta cada acte de la capella, per a cada individu, queden especificats a continuació: cada acte amb tota la capella.............11 $114 \mathrm{~s}$ acte $a m b$ violins sols.............................. 711 acte a dos cors.....................................5 11 assistència de la Capella a Viàtics............5 11 assistència a Seqüela ${ }^{155}$ i Funeral..............5 11 per Siesta ${ }^{156} \mathrm{amb}$ violins i oboès................5 11 per Siesta amb violins sols o oboès sols....4 11 per Siesta ordinària.................................3 11

24- Aquestes taxes només les podrà modificar el capítol.

${ }^{154}$ Ll.R.C. $1823-1825,14$ de novembre de 1823 , fol. $34 \mathrm{v}$.

155 La Seqüela consistia en què alguns integrants de la capella acompanyaven musicalment el difunt des de la catedral fins al cementiri.

156 Durant les Siestas es produïa la interpretació de música instrumental, en motiu de diverses festivitats. 
27- En cas de demanar-se acte amb la capella, i oferir menor salari de l'estipulat; s'acceptarà o no segons el que resolguin el mestre i els comissaris.

29- Els salaris mencionats anteriorment, s'obtenen de dividir el total en parts iguals.

30- S'exceptuarà el mestre $\mathrm{i}$ els individus que cobrin un sou anual per terces.

Al marge dels sous, durant el segle XIX tampoc canviaren massa les funcions, que seguiren essent bàsicament les mateixes que en el segle XVIII. Tot $\mathrm{i}$ això, d'un segle a l'altre es produeixen dues variacions importants; la primera és que en períodes de crisi econòmica se suprimeix l'assistència a seqüeles $i$ funerals amb la capella de música; la segona és que en tot el segle XIX no trobem cap referència a les Siestas, ni en llibres de Resolucions Capitulars, ni en els Llibres d'obra, la qual cosa sembla indicar que deixaren de realitzar-se.

El tema de les sancions per incomplir alguna norma es tractava a les ordinacions que van de la trenta-unena a la trenta-novena, i de la quaranta-unena a la quarantavuitena. El capítol multava el fet d'arribar tard a les funcions dins l'església, distingint si el retard era molt o poc; també es multava el retard en l'assistència a les processons i la falta de puntualitat als assajos.

Les ordinacions compreses entre la quarantaquatrena i la quaranta-vuitena, tracten de normes diverses. Per exemple, era obligat comunicar al capítol l'absència per malaltia, s'havia d'obeir el mestre de capella si es veia en la necessitat de canviar els papers als 
músics per cobrir alguna vacant, o la conveniència que la capella tingués un Procurador, que recollís i administrés els guanys, per a evitar conflictes entre els membres de la mateixa.

\section{ACCÉS A LA CAPELLA}

Durant els cinquanta anys objecte d'estudi, la majoria de les vegades es van convocar oposicions lliures, publicant edictes que es penjaven a les portes de la catedral i s'enviaven a les diferents esglésies. Un cop presentats, els opositors realitzaven l'examen o exàmens de l'oposició. El tribunal estava format per tres membres de la capella de música, que solien ser el mestre de capella, l'organista i el primer violí, si es tractava d'una plaça d'instrument; i si es tractava d'una plaça de veu, enlloc del primer violí hi havia el primer tenor. El tribunal realitzava un veredicte per escrit, que era llegit pels membres del capítol. Aquests resolien normalment donar la plaça a la persona recomanada pel tribunal de músics.

Només en tres casos no se seguí aquest procediment. El primer, és el del campaner Feliu Pujol, que oposità diverses vegades a la plaça de xantre, sense obtenir-la. Com que tenia molt d'interès en aquesta plaça, sol-licità al capítol que li fes un examen privat, que es realitzà el vint-i-ú d'octubre de $1815^{157}$. Però els examinadors Bernat Bertran i Josep Quilmetas no el consideraren addient.

El segon cas, és el del mestre de capella Honorat Verdaguer, que envià currículum i composicions a la

157 Per a veure aquests documents veg'is Feliu Pujol en l'apartat dels xantres, del capítol III. 
catedral per a cobrir la plaça de mestre. També sol-licità aquesta plaça l'organista de la Seu d'Urgell Antoni Coderch, del qual es rebé una carta amb els informes pertinents i composicions, el vint-i-dos de juny de $1816^{158}$. Entre aquests dos pretendents, els comissaris de música i el canonge Juncà preferiren l'Honorat, tanto en habilidad, como en ser mucho mas joven. ${ }^{159}$

El tercer cas, és el del tenor Miquel Fossalba. Intentà aconseguir la plaça vacant, en les oposicions celebrades el vint-i-quatre d'abril de 1818, sense aconseguir-la. Es tornà a presentar a les oposicions del nou de setembre del mateix any, en què es produí una segona vacant. El tribunal format pel mestre Verdaguer, l'organista Guiu i el violinista Quilmetas, el conideraren no apte per a la plaça per no haber desempeñado ni uno ni otro canto. ${ }^{160}$ Dels cinc opositors presentats, el qualificaren en tercer lloc. Tot $\mathrm{i}$ aquest veredicte, els membres capitulars resolgueren donar la plaça a Fossalba, contradint el tribunal i sense que n'hagi pogut trobar el motiu.

\section{SORTIDA DE LA CAPELLA}

Moltes vegades els membres de la capella demanaven una certificació del temps servit a la catedral. Aquest certificat els servia per opositar a d'altres llocs.

\footnotetext{
158 Tinc notícia de la rebuda de la carta a través de les actes capitulars, però malauradament no l'he poguda trobar.

159 Ll.R.C.1815-1817, 12 d'agost de 1816, fol.120. Per veure aquest document complet, així com els referents a la rebuda de les cartes, vegi's l'apartat dels mestres de capella del capítol III.

${ }^{160}$ Ll.R.C. 1817-1819, carta inserta entre els fols. $92 \mathrm{v}$ i 93 . Aquest document, així com la resta de documents referents a aquest músic, es poden veure complets en l'apartat dels tenors del capítol III.
} 
Després demanaven un permís temporal per anar a fer les oposicions. Si obtenien la plaça desitjada, llavors feien la renúncia formal, enviant una carta al capítol, amb el segell de la nova església.

Com a exemple, ofereixo la petició de certificat de Fossalba, tot $\mathrm{i}$ que després no demanà cap permís per a sortir de la catedral, i restà a la mateixa durant molts anys.

El R. Miguel Fosalva, por memorial, pedía una Certificacion del/ [fol. 22] tiempo que sirve en la Ygl. ${ }^{a}$ y su comportamiento./ Res. $^{\text {on }}$ Que el Can. ${ }^{o}$ S. ${ }^{\text {rio }}$ de la Certificacion q. $^{e}$ se pide. ${ }^{161}$

\section{PERMisos, MALALTIA I JUBILACIÓ DELS MÚSICS}

Com era obligació, segons les ordinacions, cada vegada que un membre de la capella volia marxar uns dies, havia de demanar permís per escrit als comissaris de música, comunicant el motiu de la sortida i el nom de qui el substituiria. Els comissaris passaven la petició mitjançant un memorial, al capítol de canonges. La resolució presa quedava reflectida als llibres d'actes. ${ }^{162}$

Entre els motius més freqüents per sortir, hi havia el de realitzar un descans annual durant la canícula d'estiu. Així, era habitual que alguns músics sol·licitessin un mes per a descansar, ja fos el juliol o l'agost, o entre el quinze de juliol i el quinze d'agost. Alguns músics

\footnotetext{
${ }^{161}$ Ll.R.C. 1829-1831, 1 d'abril de 1830, fol. 21v i 22.

${ }^{162}$ En l'apartat de les ordinacions, vegi's l'ordinació nº5.
} 
demanaven aquest descans en èpoques diferents de l'any. L'organista Antoni Guiu, cada any sol-licitava un mes d'estiu, per anar a prendre els aires frescos de Sant Joan de les Abadesses. El xantre Santamaria solia demanar el descans abans de Setmana Santa.

Altres vegades el permís era demanat per anar a visitar els pares i la família.

Prop. ${ }^{n}$ Los R.R. Ramon Bassas y Felipe Comella Benef. ${ }^{\text {dos }}$ des-/tinados a la Capilla de Musica piden licencia $p .^{a}$ ir a visi-/tar $\hat{a}$ sus Padres y Parientes por espacio de un mes./

Res. ${ }^{n}$ Placet: como cuiden quien supla por ellos en su ausen-/cia en el coro y actos de Musica. ${ }^{163}$

En cas de malaltia, també s'havia de comunicar als comissaris, moltes vegades mitjançant un justificant mèdic.

Yte. Un Monacillo de Coro Adrobau presento certificacion de Cirujano,/ por la que consta, que para curar de su enfermedad llamadal optalmia, le es preciso pasar á su pais á respirar los aires na-/tivos, y tomar las aguas minerales de S. Hilario./

Resol. Que se vaya. ${ }^{164}$

No s'ha trobat cap document que faci una referència directa a la jubilació dels músics. A partir de la documentació estudiada, es dedueix que els músics

\footnotetext{
${ }^{163}$ Ll.R.C.1819-1821, 12 de juny de 1819, fol. 3v.

${ }^{164}$ Ll.R.C. 1815-1817, 28 de juny de 1816, fol. 110.
} 
s'estaven a la catedral complint el càrrec, de la manera que podien, fins al seu traspàs, fet que ocasionava que moltes vegades alguns músics havien d'intentar suplir els més grans o impedits. Vegi's aquest exemple del contralt de la capella Esteve Buixó.

Itt: Ley otro Memor. ${ }^{l}$ del R. Buxó Musico con un Certi-/ficado del Medico Gelaber que acompañaba, pidiendo $q .{ }^{e} /$ el Cabildo en consideracion à sus enfermedades $y$ acha/ques de q. ${ }^{e}$ certifica el facultativo tenga la bondad del dispensarle por algun tiempo de hacer las semanas/ en el Coro, cuya fatiga perjudica à su salud, hasta tanto/ que con el beneficio de los remedios haya recuperado/ fuerzas./

Res. Que el Cabildo por su parte le dispensa por algun/ tiempo el que dicte la prudencia atendido el estado del su salud; pero que los demas Beneficiados Musicos se han del encargar y obligar à prestar el servicio que debia/ hacer el solicitante. ${ }^{165}$

${ }^{165}$ Ll.R.C. 1803-1807, 26 d'octubre de 1805 , fol. $224 \mathrm{v}$. 


\section{FUNCIONS MUSICALS DE LA CAPELLA}

\section{FUNCIONS EXTRAORDINÀRIES: FESTIVES I DOMÍNIQUES}

\section{a) Consideracions generals}

Hi havia diferents tipus de funcions, segons el dia que se celebraven. Les ordinàries eren les que formaven part de la quotidianitat del culte. Les extraordinàries estaven constituïdes per les domíniques, les festivitats habituals del calendari i les celebracions per motius excepcionals. També hi havia funcions en altres esglésies, a les que hi assistia la capella en ple. El músic estava obligat a ser-hi en totes elles $\mathrm{i}$, en cas de no ser-hi, justificar el motiu de l'absència als comissaris de música, tot deixant un substitut que complís les seves obligacions.

En les funcions ordinàries els músics que tenien obligació d'alfuller, havien de cantar en els Oficis al faristol, vestits amb capes.

Itt: El Sr. Juncá propuso que los Alfulleres asistan a los/ oficios y al Facistol con capas como siempre se hacia/ antes de la Guerra, y que al Yntroito y demas que se can-/ta en el facistol bage alomenos el Sochantre Semanero./

Res. Que de ahora en adelante se haga con arreglo a la/ propuesta del Sr. Juncá, y que se avise al Sacristan/ tenga siempre prontas las Capas. ${ }^{166}$

${ }^{166}$ Ll.R.C. $1815-1817,17$ de maig de 1815 , fol. $168 \mathrm{v}$. 
De funcions extraordinàries, si atenem a la formació instrumental i/o vocal que hi assistia, n'hi havia de tres tipus. Les funcions amb tota la música, eren amb instruments i cors. Les funcions a cors amb orgue i dos cors, i sense instruments, només amb les veus i orgue. Les funcions amb faristol, eren sense instruments. Aquests tres tipus de funcions les tenim ben determinades gràcies un document aparegut a les actes, datat el catorze de novembre de l'any 1823 .

\section{Funcions amb tota la músical}

El Dimecres i Dijous Sant; les Lamentacions i Miserere./

El diumenge de Pasqua; l'Ofici./

L'hora de Nona de l'Ascensió.

El Diumenge de Pentecostes; l'Ofici./

La festa de Corpus; les Maitines, Ofici $i$ Professó./

L'Assumpta; Idem./

Dia de Difunts; l'Ofici./

La Concepció; les Maitines, Ofici $i$ Professó./

La Professó de St. Narcís./

La Nativitat del Senyor; les Maytines, Missa del Gall i Mis/sa Major./

Els Funerals Canonicals/

Oficis dels Vots de St. Narcís./

$\underline{A \text { Cors } /}$

En la Circuncisió; l'Ofici./

En l'Epifania; Id./

En la Purificació; Id./

En St. Narcís de 18 de març; Id./

En l'Anunciata; Id./ 
El Dijous Sant; Id./

Cada dilluns de les dues Pasques; Id./

En l'Ascensió; Id./

En la Trinitat; Id./

En la Nativitat de la Verge; Id./

En Tots Sants; Id./

En St. Esteve Proto Martir./

En tots els diumenges de Minerva; l'Ofici i la

Professó./

Amb Faristol/

En les Dominiques d'Advent i Quaresma; la Missa./

El Diumenge de Rams; la Missa i Passió com és costum./

El Dimarts, Dimecres i Dijous Sant; el Passio com és costum./

En la manifestació de la Vera Creu; Idem./

En l'entrada de les quaranta hores, i al posar i treurel

el S.Sm Sacrament del Monument; com es feia antigament. ${ }^{167}$

\section{b) Algunes de les festivitats més importants}

A partir de la documentació estudiada, han aparegut documents referents al procediment que s'utilitzava per a celebrar algunes de les festivitats més importants. La majoria d'aquestes informacions pertanyen als anys de la Girona napoleònica; sembla ser que posaren un nou president del capítol de canonges, que no coneixia la tradició de les festivitats cel-lebrades a la catedral. Llavors, en els llibres d'actes apareix

${ }^{167}$ Ll.R.C. $1823-1825,14$ de novembre de 1823 , fol. $34 \mathrm{v}$. 
l'explicació de com es feien aquestes funcions en anys anteriors, i es demana el vist-i-plau del president per a no variar la tradició. Cal dir que no apareixen totes les festivitats més importants, en falten de destacades, com podria ser el dia de Nadal o Sant Esteve; tot i això m'ha semblat interessant recollir les disposicions que he pogut anar trobant, com a fidel testimoni del que es realitzava en l'època.

\section{b.1. Processó de Sant Narcís del divuit de març}

El divuit de març se cel·lebrava l'ofici i la processó de Sant Narcís. L'ofici era amb la capella de música, i en la processó es cantaven villancets. El següent document remarca la gran devoció que tenia la ciutat al sant. L'estima pel sant que es veia augmentada en períodes de gran inestabilitat política i social, i era una forma de mostrar el desacord amb la invasió francesa. Aquest document, datat el catorze de març de l'any 1814, pertany al període final de l'ocupació francesa. Els ciutadans gironins, demanen permís per concórrer a la processó amb torxes.

El Sr. Presidente propuso: M.Y.S. tengo recado de la/ Ciudad suplicando a V.S. se haga la Procesion el dial de Sn. Narciso, y permita, que los Ciudadanos que ten-/gan devocion de concurrir a ella con hachas/ lo hagan, para satisfaccion del Pueblo./

Res. Que el Cabildo accede a la suplica de la Ciudad:/ Que el Sr. Obrero cuide el adorno de la Ygla.y el Sr. Perez de la Musica. Los oficios den la confor-/midad siguiente, Visperas ordinarias. Dia del Santo/ [fol. 48] por la mañana a la hora regular: Oficio con 
Música y/ Sermon; Segundas Visperas con Solemnidad; por la tarde se entra a la hora ordinaria: Completas a Coretos; lue-/go la Procesion, con Villancicos, y musica en los parages/ acostumbrados. ${ }^{168}$

\section{b.2. $\underline{\text { Corpus }}$}

Per Corpus, a més a més de les funcions religioses, es feien professons $\mathrm{i}$ es cantaven villancets. El dia de Corpus al matí es feia l'Ofici amb orgue, dos cors i la capella de música. A la tarda es cantaven les Vespres i les Completes amb solemnitat i es feia la professó pel camí més llarg. A l'arribar a la plaça Ciutadans ${ }^{169}$ es cantaven dos villancets. ${ }^{170}$

El dia de l'Octava, la professó era per dins la catedral; se sortia per la porta principal (la de la gran escalinata), es donava la volta al pati que hi ha davant la porta dels Apòstols, s'entrava per aquesta porta i després es cantava un villancet amb l'acompanyament d'instruments en el replà que hi ha darrera del cor. ${ }^{171}$

Itt: Propuse, M.Y.S. hallandonos proximos/ a las funciones de Corpus, disponga V.S. lo quel tenga por conveniente para solemnizarla: el/ año pasado se hizo de la manera siguiente:/ el miercoles por la tarde se entró a las 4 horas;/ se expuso el

\footnotetext{
${ }^{168}$ Ll.R.C. 1812-1815, 14 de març de 1814, fol. 48.

${ }^{169}$ La plaça que hi ha davant de 1'ajuntament, actual plaça del Vi.

${ }^{170}$ Ll.R.C. $1812-1815,11$ de juny de 1813 , fol. $28 \mathrm{v}$.

${ }^{171}$ Idem.
} 
Sacramento, luego Visperas y Completas/ cantadas. Acabadas estas se comenzaron los/ Maytines, y los Salmos Benedictus é Himnos/ se cantaron con el Organo con Solemnidad./ El Jueves se entro al Coro por la mañana a las nueve. Exposicion del Sacramento, Prima, tercial [fol. 2v] y Sexta cantadas con bastante Solemnidad, es-/pecialmente la Tercia, y despues el Oficio con el/ Organo à Coros, asistiendo la Capilla de Mú-/sica que comenzó a las diez con corta diferencia./ Nona cantada, y luego se reserva de suerte,/ que da fin a la funcion a las once $y$ un cuarto/ con corta diferencia. Por la tarde se entra a/ las 4 y $1 / 2$. Visperas cantadas $y$ Completas con solemni-/dad. Organo al Benedictus. Nunc dimitis el Himnos. Concluido esto si la Municipalidad/ y han concurrido a la Ygla. Se arreglal la Procesion por la Carrera mas larga, sin enItrar por Sn. Telm, sinó bajando rectamentel por la Calle entre Capilla de Sn. Narciso y Capuchinos, siguiendo el Carrer del Llop, de la/ banca, y todas las calles y plazas acostum-/bradas. En los dias de Octava se entra a la hora acostum-/brada, [...]. Por la tarde a las 4 y 1/2 pro-/cesion por la Yglesia, y Patio, Villancico con/ Musica; y lo mismo en el dia de la festivi-/dad, dos Villancicos con Musica. V.S. deter-/mine si se ha de hacer lo mismo este año./

Res. Que se haga el mismo orden propuesto. $^{172}$

${ }^{172}$ Ll.R.C. 1812-1815, 26 de maig de 1812, fol. 2 i $2 \mathrm{v}$. 


\section{b.3. L' Assumpta}

He trobat dos documents referents a com es cel-lebrava la festivitat de l'Assumpta. El primer és del deu d'agost de l'any 1812, i parla sobretot de com es farà la Vigília; després la informació queda incompleta, ja que els canonges passen a parlar d'altres temes.

Propuse: M.Y.S. La proximidad de la festividadl de la Asunta pide que V.S. determine con anici-/pacion lo que corresponde se haga para solem-/nizar esta funcion principal de la Yglesia./

Resol. Que por lo que hace al Cabildo se haga co-/mo se ha hecho en los demas años despues del las novedades de la Guerra: la Vispera sel Cantaran los Maytines con solemnidad entran-/do a las 3 y $1 / 2$, los 3 principales Salmos de los Noc-/turnos con organo; $y$ asimismo los Hymnos/ $y$ Magnificat, y Benedictus, $[\ldots]^{173}$.

La segona informació és del vuit de novembre de l'any 1813 , i es comprova com celebraven el dia de 1'Assumpta. Després de l'ofici feien la processó, pel camí més llarg, i dos villancets amb instruments a la plaça de la ciutat. En aquest cas, es cantà un Te Deum després de l'ofici, per petició del governador. El dia de l'octava de l'Assumpta, la processó segurament era pels voltants de la catedral, $i$ es cantava un sol villancet amb instruments. ${ }^{174}$

\footnotetext{
${ }^{173}$ Ll.R.C. 1812-1815, 10 d'agost de 1812 , fol. $8 \mathrm{v}$.

${ }^{174}$ Tal i com es feia en l'Octava de Corpus.
} 
La Misa sera con Musica, como se ha hecho los demas años, el Sermon despues del Evangelio/ y concluido el oficio el TeDeum, según se hal pedido por el Gobierno con las Oraciones señala-/das que tiene el Maestro de Ceremonias [...]/ Procesión por la Carreral larga bajando por las Capuchinas, sin entrar en Sn. Feliu. Villancicos con Musica en la Plaza y Ciudad. Dia de Octava se entrarál a las 4 y $1 / 2$ Villancico con Musica. ${ }^{175}$

\section{b.4. Sant Narcís del vint-i-nou d'octubre}

La festa més grossa de la ciutat era la de Sant Narcís del vint-i-nou d'octubre. En aquesta acta capitular, no s'explica el procediment seguit en la festivitat, però sí que es mostra la gran importància que tenia aquesta celebració per als gironins.

Propuse M.Y.S. Mañana es el dia de Sn. Narciso/ y convendrá que V.S. disponga lo convenientel en el caso que tenga a bien bajar a Sn./ Feliu; para su inteligencia en el año pasado sel celebró esta función a expensas de V.S. $y$ en el/ anterior concurrieron varios devotos que la pidieron a V.S. Este es un Santo de la mayor devoción de esta Ciudad [...]/

Resol. Que el Cabildo se halla pronto a celebrar/ esta Función, y concurrir a la Colegiata pagando/ la Musica, Cera y demás

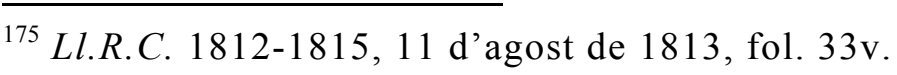


que sea necesario si aca-/so por otro método no se puede excusar este gasto/ pues aunque el Cabildo no está en disposición/ de concurrir a estas expensas, los motivos releIvantes que concurren le ponen en la precaución/ de no omitir esta función. ${ }^{176}$

\section{b.5. Tots Sants i Difunts}

Per a Tots Sants hi havia costum de cantar amb dos cors l'Ofici. I el dia de Difunts, fer l'Ofici amb tota la capella de música.

$5^{\circ}$ El Sr. Canonigo Micalet recordó, que era preciso determi-/nase el Cabildo, si en el proximo dia de todos los Santos, / y en el de la conmemoración de los Difuntos se celebrarian/los Oficios con Música.I Resol. En la fiesta de todos los Santos se cantará el Oficio á coros, y en el/ dia de los Difuntos será con Música. ${ }^{177}$

\section{b.6. La Puríssima}

Per la Puríssima, hi solien assistir les autoritats municipals, i es feia l'Ofici amb orgue i dos cors, i llavors es feia la processó per dins de la catedral.

Dio aviso la Municipalidad de que mañana dia/ de la Purisima Concepcion de la Virgen asistirial al Oficio siguiendo la costumbre antigua:/ y que concurriria a las diez poco

\footnotetext{
${ }^{176}$ Ll.R.C. 1812-1815, 18 d'octubre de 1812, fol. 14 .

${ }^{177}$ Ll.R.C. 1823-1825, 25 d'octubre de 1823, fol. $32 \mathrm{v}$.
} 
mas o menos./ Sobre lo que resolvera el Cabildo./

Resol. Que el Oficio sea con organo a coretos: quel se haga por la Yglesia la Procesión con la Veró-/nica. En lo demás que los Maytines se semito-/nen por la mañana en el dia de la festividad, aunque con alguna solemnidad. Tercia, sextal y Nona cantadas sin tratar de procesión por las ........[?] en la conformidad que en los dos/ años anteriores, $y$ esto se hará saber a la Ciudad. ${ }^{178}$

\section{b.7. La Passió}

La primera informació és dels llibres d'obra i es refereix a la Passió, on consta que el xantre que feia el paper d'Evangelista i el cantor que feia el paper de Jesús, atès que tenien més feina que la resta de músics, cobraven una proporció més elevada.

\section{$\underline{\text { Passios/ }}$ \\ Itt, paga la Obra à la Capella de Musi-/ca $10 \mathrm{ll}$. s per cantar los Passios en estal forma; per lo Cos de la Capella 4 ll. s, $\ddot{y}$ p. ${ }^{r} /$ los que fan de Evangelista $\ddot{y}$ de Jesus $6 \mathrm{ll}$. s./ à fi de que à estos dos los corresponga $15 \mathrm{~s} . / \mathrm{per}$ quiscun cada dia los toquia cantar el/ Passio i fou resolt à 11 Mars $1790 \ldots 10 \mathrm{ll} \mathrm{s}{ }^{179}$}

Segons la Consueta de l'organista escrita per Antoni Guiu, la Passió es cantava el Diumenge de Rams, Dimarts i Dimecres i Divendres Sant.

\footnotetext{
${ }^{178}$ Ll.R.C. $1812-1815,7$ de desembre de 1812 , fol. $16 \mathrm{v}$.

${ }^{179}$ Ll.C.O. $1809-1815$, fol. 88.
} 
Die 7. Dom. ...[?] Ofici y Pacio al Coret Vespres à 2 cuars del 3 Vexilla al Coret. Se comensan las 40 Horas à las 4/ de la Tarde. En totas las horas que hi ha musical se toca lo Oganet antes y despues del Sermo./

Die 8. Dilluns S. ${ }^{\text {to }}$ Feria, Vespres, Vexilla al Coret./ Lo procurador de la Capella dirà las Oras de mu-/sica y Orga à que se ha de tocar en las 40 Horas./

Die 9. Dimarts S. ${ }^{\text {to }}$ Feria, Pasio $y$ Vexilla./[fol. 15]

Die 10. Diumenge ${ }^{180}$ S. ${ }^{\text {to }}$ Feria Pacio Vexilla, Matinas àl las 4 de la tarde./

Die 12. Divendres S. ${ }^{\text {to }}$ Si lo S. ${ }^{r}$ Yll. $^{m}$ fa la funciól se en-/tra à 9 horas 'y si no à dos cuars de nou. Pacio ab/Musica. A la tarde se entra à Matinas àl dos cuars de 4. Se Canta lo Miserere à dos Cors. ${ }^{181}$

\section{VARIACIONS DE LES CERIMÒNIES EN CASOS CONCRETS}

\section{a) Coincidència de funcions en llocs diferents}

En l'acta capitular del vint-i-nou d'abril de l'any 1808, hi ha exposada la queixa dels comissaris de música al capítol, referent a que alguns músics de la capella han volgut guanyar doble sou, assistint a dues funcions al mateix temps. Aquests varen anar primer al monestir de Sant Daniel, marxant de seguida cap al convent de Sant Josep on s'hi celebrava una novena. Aquest motiu va

\footnotetext{
${ }^{180}$ Aquí hi ha un error; segurament Guiu volia posar dimecres.

181 ACCG: GUIU I ROQUER, A. Consueta per lo regimen del Organista de la Cathedral de Gerona, (manuscrit) ps. 14 i 15.
} 
provocar malestar entre els altres músics. El mestre de capella era del parer que tinguessin una amonestació amb una rebaixa de tres sous. El capítol hi estigué d'acord.

Itt: Dn. Sebastian propuso: M.Y.S. Algunos Musi-/cos que asistian a una de las funciones, que se cele-/bran en el Monasterio de S. Daniel extramuros/ de esta Ciudad, se ausentaron de la funcion/ [fol. $105 \mathrm{v}$ ] poco despues de haberse comenzado, con el fin del pasar â Sn. Joseph donde se hacia la Novena, y ga-/nar por dos partes. Se han quexado los demas de quel sin haber cumplido en Sn. Daniel se hayan de apro/bechar de toda la distribucion. Preguntado el/ Maestro sobre esto dice que se les deben rebajar/ tres sueldos. Los Comisarios de Musica que paral arreglar este asunto nos vimos con los Musicos./ acordamos que se les rebajasen los 3 s. pero algunos/y uno de ellos con especialidad respondio con alta/neria, y poca atencion; en vista de esto no qui/simos pasar adelante hasta que V.S. haya acorda/do lo que se debe hacer. Tambien pretendian/ pribar al R. Pages de la distribucion por ha/ber faltado un dia â Sn. Feliu, sin embargo del que hacia ver que sus achaques, y la lluvia lel impidieron concurrir. V.S. determinara./

Res. Que los Musicos esten â lo que acordaron los/ SS. Comisarios de rebajarles 3 s. de la funcion del S. Daniel; y al Musico que se excedio, que se reba-/ge la mitad. $Y$ que respecto que el $\mathrm{R}$. Fran. ${ }^{c o} \mathrm{~Pa}$-/ges, sobre las indisposiciones que padecia, que son/ notorias, no pudo concurrir â la funcion 
impe-/dido por la lluvia se le contribuya con la por-/cion que le corresponde sin ningun desfalco. ${ }^{182}$

No he observat que es repetís cap altre fet similar en la documentació estudiada.

\section{b) Canvis produïts per situacions meteorològiques adverses}

El vint-i-sis de maig de 1802 el president del capítol de canonges proposa que la processó de lletanies es faci pels claustres, a causa del mal temps. Aquest fet es produirà sovint al llarg dels cinquanta anys estudiats.

El Sr. Presidente propuso que se hiciera la Procesion de Le-/tanias por los Claustros, respecto de no poder hacersel por las Calles acostumbradas a causa del mal tiempo./ Res. Placet. ${ }^{183}$

El vint-i-tres de desembre de l'any 1805, els canonges diuen que han caigut fortes nevades sobre la ciutat de Girona. A causa del fred, proposen que les maitines dels dies festius i dels diumenges, enlloc de ferles cantades es facin resades, per no cansar tant els residents. Com que el document és bastant llarg, en reprodueixo només un fragment; es pot veure complet al final d'aquest volum, en l'apèndix de documents, com a $\mathrm{n}^{\circ} 1$ : Proposta de canvi en l'hora de les matines.

\footnotetext{
${ }^{182}$ Ll.R.C. 1807-1812, 29 d'abril de 1808, fol. $104 \mathrm{v}$.

${ }^{183}$ Ll.R.C. 1800-1803, 26 de maig de 1803, fol. 300v.
} 
Itt: El Sr. Presidente propuso. M.I.S. en el ultimo Cabildo/ de Coro quedo acordado, que en el primer Cab. ${ }^{\circ}$ Ord. ${ }^{\circ}$ se tratase de arreglar el punto de residencia; pues/ parece que el tiempo se inclina a bonanza, y que/ ha cesado el motivo de haverse esta variado o/ alterado los dias pasados por las nieves./

Res. Que se vote sobre este asunto. Dicho Sr. Presidentel dixo no soi de voto que se inove el metodo de las horas/ [fol.234] segun esta establecido, ni en orden al canto en/los dias ordinarios; pero con respecto à las Ferias, y/ Dominicas, se pudieran decir semitonados los Mayti-/nes pues de esta manera irian mejor, $y$ no se fati-/garian tanto los residentes; y que acabados los Mayti-/nes en dchos dias se continue cantando como sel hace ahora. Siguieron votando los SS. Capitulares y sel noto variedad en los votos [...] quedando acordado quel se siga como hasta aqui; y que para tratar/ sobre ferias y Dominicas queden Comisionados/ los SS. Molinas Valparis, Junca y Cuffi. ${ }^{184}$

El vint-i-set de gener es llegí la proposta presentada pels canonges comissaris de música, consistent en cantar les maitines de les domíniques més rellevants, i resar en les restants domíniques, ja que feia bastant fred, havíen caigut fortes nevades i els residents anaven molt cansats. També proposaren que en algunes maitines de les domíniques de quaresma es pogués entrar a les set. Aquesta proposta motivà una enèrgica protesta per escrit del canonge Rabal, posant el crit al cel que es canviessin

${ }^{184}$ Ll.R.C. 1803-1807, 23 de desembre de 1805, fol. 233v i 234. 
les constitucions de l'any $1722^{185}$. Tot i això, el capítol accedí a la proposta dels comissaris. Com que el document és molt llarg, però interessant, es troba complet en l'apèndix documental, el $\mathrm{n}^{\circ} 2$ : Carta del canonge Rabal, de 27 de gener de 1806.

Itt: Los SS. Molinas Torrent, Juncà y Cuffi hicieron presen-/te. M.I.S. en el Cabildo del 23 de Diciembre proximol pasado acordo V.S. à los Canonigos infraescritos, los quales en su cumpli-/miento hacen presente, que se podran Cantar los/ Maytines de la primera Dominica de Adviento, los de la Vi-/gilia de Navidad, y los del Miercoles de Ceniza: y sel podran semitonar todos los Mayitines de las demas/ Dominicas y Ferias, empezando à cantar el Te Deum/ quando lo haya, y si no lo hai, se cantaran las Laudes/ y demas Horas, que se siguen, encargando à los So/chantres, que entonen con gravedad, y cuiden se ha-lgan los dos puntos, cuyo cumplimiento deberia zelar el Sr./ Presidente del Coro. Las horas de entrar à los Mayitines/ respectivas à los tiempos no se deben alterar. A los Maytines de las Dominicas de Quaresma en la en quel haya Minerva, y en las ferias Sextan [?], quando hay/ Penitenciales, bastara entrar à las siete, sinque sea/ necesarios empezarlos à tres quarto para las 7./ V.S. dispondra en todo lo que sea de su mayor agrado/ Gerona 23 de Enero de 1806. Miguel Molinas Comisario; Joseph/ Torrent Canonigo; Francisco Junca Comisario . Julian Cuffi Canonigo/

${ }^{185}$ El canonge Rodó es remet a les constitucions de 1722, encara més antigues que les de 1735 . 
Al tiempo de votarse sobre lo expuesto por los SS. Co-/misionados el Sr. Rabal leyo un papel que tenia/ escrito al efecto [...]

Res. Que se este à lo resuelto, y plan presentadio por/los SS. Comisarios. ${ }^{186}$

La nit del divuit al dinou de setembre de 1843, es produïren a Girona fortes pluges que provocaren unes greus inundacions al barri de Sant Pere, amb nombroses víctimes. El capítol resol celebrar un funeral solemne en memòria de les seves ànimes pel desembre del mateix any, proposant que hi hagi música o cant de franc, si els músics troben adient de participar-hi.

Celebrar un solemne funeral en sufragio de las almas que fueron víctimas de las inundaciones del barrio de Sn. Pedro de esta ciudad en la noche del 18-19 de 7bre ultimo, se ofrece a cantar oficio gratis.

Res. Avisar Maestro de Capilla, que si los musicos gustan prestarse se tendra con musica y si no con canto gratis. ${ }^{187}$

\section{c) Altres circumstàncies que modifiquen la normativa litúrgica}

Com s'ha vist en l'apartat anterior, en general els canonges de la catedral eren molt reacis a canviar la normativa, però en el cas dels setges de Girona els anys 1808 i 1809 , alguns canvis foren inevitables per imperatiu de les circumstàncies.

\footnotetext{
${ }^{186}$ Ll.R.C. $1803-1807,27$ de gener de 1806, fol. $242 \mathrm{v}, 243$ i $243 \mathrm{v}$.

${ }^{187}$ Ll.R.C. $1843-1846,18$ de desembre de 1843, fol. 6.
} 
El tretze d'agost de l'any 1808 suspenen la funció de l'Assumpta, doncs les tropes franceses estan llençant granades i bombes a la ciutat.

Propuso el Sr. Presidente el motivo de juntarse V.S. en/ esta ocasion es para tratar de hacer ô dejarl de hacer la funcion acostumbrada con motivo/ de la festividad de la Asunta. Los peligros en quel se halla esta Ciudad con el enemigo â la vistal cañoneandola $y$ enviandola inumerables granadas y/ bombas y a los que. V.S. y podra acordar lo conveniente./

Res. Que se suspenda la funcion acostumbrada $[\ldots]^{188}$

El vint-i-quatre de desembre de l'any 1808 , acorden cantar les Matines de Nadal, la tarda del dia anterior, doncs hi ha molta tropa allotjada a la catedral.

Con tanta tropa como hai puede dar motivo $\hat{a}$ muchas/irreverencias y aun escandalos, si se cantaban los/ Mayitines de media noche en adelante; por esta causa/ convendra que V.S. determine acerca de esto lo quel tenga por mas conveniente./

Res. Que se tengan los Maytines en la tarde de hoy/ comenzando un poco antes de las quatro, para lo quel haga la señal acostumbrada el Campanero: estos/ deben cantarse con toda solemnidad acompañanIdo la Musica pero sin Villancicos. Que maña-/na se entre $\hat{a}$ las seis, se empiezen Laudes (antes la/ Misa del Gallo; tambien

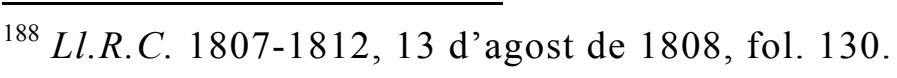


con Musica) que se continuel la Prima, y luego la segunda Misa; si sobra algun/ tiempo hasta las nueve $q .^{e}$ sirva este de descanso/ â los residentes, y a las nueve se empiece tercial con todo lo demas que se hace siempre en un dial tan solemne. Los Campaneros deben tocar â sus ho-/ras correspondientes $[\ldots]^{189}$

Aquest darrer document és del vint-i-u d'abril de 1'any 1809 , i fa referència al toc de campanes. Els metges de la ciutat demanen al capítol, que es moderi el repic de campanes en els enterraments, doncs el nombre de malalts és molt elevat, i aquest fet provoca tristor entre els ciutadans.

Cal dir que com a conseqüència dels setges dels anys 1808-1809, es produí un gran nombre de baixes. Hi hagué els ferits i caiguts per les conteses, a més, la falta d'aliments i la precarietat de les vivendes, que havien sofert moltes destrosses, provocaren un gran nombre d'epidèmies. Arrel dels setges moriren unes quatre mil persones, el que representava la meitat de la població de Girona. ${ }^{190}$

Propuso tambien dcho. Sr. Presidente que en considera-/cion a las enfermedades que corren, y que los Medi-/cos son de parecer que las campanas se toquen/ poco siempre que ocurren entierros al fin de no/ contristar [sic] â los enfermos y sanos, [...]. ${ }^{191}$

\footnotetext{
${ }^{189}$ Ll.R.C. $1807-1812,24$ de desembre de 1808 , fol. $157 \mathrm{v}$.

${ }^{190}$ Vegi's el "Marc històric" al capítol I.

${ }^{191}$ Ll.R.C. 1807-1812, 21 d'abril de 1809, fol. 183v. Hi ha un error en la numeració, doncs hi ha dos folis amb numeració 183 seguits.
} 


\section{EL CANT DEL TE DEUM AMB MOTIU DE DIADES O CELEBRACIONS ESPECIALS EN LA CATEDRAL DE GIRONA}

Cada vegada que se celebrava algun esdeveniment important, després de l'ofici es cantava un Te Deum, càntic en acció de gràcies a l'Altíssim. Solien ser encomanats per l'ajuntament, la junta provincial o l'autoritat que governés en aquell moment. Els mestres de capella realitzaven composicions noves per a aquestes celebracions. La majoria de Te Deum eren cantats per motius bèl-lics, la proclamació i jura de reis i fets polítics de rellevància, com ara la jura de constitucions. Com que hi ha molta informació referent a Te Deum i rogatives, no he transcrit tots els documents a que es fa referència, doncs l'estudi esdevindria molt llarg. Tot i això, de cada document en surt la referència, per a poder-lo localitzar. $\mathrm{He}$ transcrit els documents que m'han semblat més interessants. Totes informacions que apareixen a continuació són extretes dels llibres de Resolucions Capitulars de la Seu gironina, i en la mesura que m'ha estat possible, he intentat agrupar les notícies per blocs temàtics, tenint en compte un cert ordre cronològic.

\section{a) Pregàries i accions de gràcies per epidèmies}

El dia primer d'octubre de l'any 1833, es realitzen rogatives públiques per a aturar l'epidèmia de cóleramorbo. ${ }^{192}$ Aquestes rogatives continuaran el vint-i-quatre d'octubre de $1833 .{ }^{193}$ A través dels llibres d'actes sabem

\footnotetext{
${ }^{192}$ Ll.R.C. 1833-1835, 4 d'octubre de 1833, fol. 13.

${ }^{193}$ Ll.R.C. 1833-1835, 24 d'octubre de 1833, fol. 15.
} 
que l'epidèmia de còlera a la Península, fineix el trenta-u de gener de l'any 1834 .

No obstant, els casos de malaltia de cólera-morbo sembla que continuen uns anys més. Així, a les actes capitulars s'indica que es tornen a realitzar més rogatives el sis d'agost, el vint-i-un d'agost i pel setembre de 1834. Les darreres notícies sobre aquestes pregàries són del setembre de $1836 .{ }^{194}$

\section{b) Recepció de tropes a la catedral}

El vint-i-nou de maig de l'any 1809 , el capítol fa constar que l'endemà, i en motiu de la diada de Sant Ferran, el general i governador de Girona, Mariano Álvarez de Castro, té previst fer una recepció a la catedral de les tropes i dignataris de la ciutat.

El Sr. Presidente propuso, que con motivo de la festividad/ de Sn. Fernando que celebra la Igla. mañana,/ General y Governador de esta Plaza Sr. Dn. Mariano/ Alvarez recibe a todos los Cuerpos Militares, Cabal-/leros y demas personas de distincion en celebri-/dad de los dias de nuestro amado Rey. [...] $]^{195}$

El vint-i-un de gener de $1824,{ }^{196}$ canten per ordre del comandant francès, una missa solemne per S.M. el rei

\footnotetext{
${ }^{194}$ Ll.R.C. $1835-1837,16$ de setembre de 1836 , fol. $12 \mathrm{v}$.

195 Ll.R.C. 1807-1812, 29 de maig de 1809, fol. 191. Aquesta recepció es va fer en uns moments molt crítics per a la ciutat de Girona, ja que es trobava en ple setge de les tropes napoleòniques.

${ }^{196}$ Recordem que el 1823 s'havia produitt la invasió francesa dels Cent Mil Fills de Sant Lluís.
} 
de França, a imitació de les que se celebren a França en aquest dia, per assistir-hi ell amb la seva tropa.

$6^{a} \quad$ Se leyó un oficio del Sr. Obispo insertando el comunicado por el Comandante Frances/ relativo a la celebracion del Aniversario solemne el dia veinte $y$ uno proximo en/ memoria de Luis 16 Rey de Francia. Num ${ }^{\circ} 22 /[\ldots] /$ Juan Miguel Obispo de Gerona./

Resol. Contestese que se hara dicho dia a las 10 de la mañana, con Musica colocando sobrel el Feretro una Corona y Cetro insignias de la Dignidad Real. ${ }^{197}$

Annex $\mathrm{n}^{\circ} 22$ :

M.Y.S./ El Sr. Comandante frances de esta Plaza acaba de comunicarme verbalmente que el Sr. Comandan. ${ }^{t e}$ General Ma-/tignoné desde Barna le previene que el dia 21 dell corriente debe cantarse en esta Sta. Ygla una Misa So-/lemne por S.M. el Rey de Francia, á imitacion del igual funcion, $q{ }^{e}$ en tal dia se hace en las Yglesias/ de aquella Monarquia à la que asistira dicho Comandan-/dante con su tropa $[\ldots]^{198}$

\section{c) Visita a Girona del rei Carles IV}

El vint-i-tres d'octubre es produeix la visita del rei Carles IV, amb els prínceps i el rei d'Etrúria, a la Seu.

\footnotetext{
${ }^{197}$ Ll.R.C. 1823-1825, 16 de gener de 1824, fol. 42 .

${ }^{198}$ Ll.R.C. 1823-1825, al final del llibre, annex $\mathrm{n}^{\mathrm{o}} 22$.
} 
Les notícies del possible pas del rei per la catedral, comencen a córrer el quatre de setembre de l'any 1802 .

Itt: El S. ${ }^{\text {or }}$ Valparis en nombre suyo $y$ del Penitenciario/ comisionado, para tratar con el $S .{ }^{\text {or }}$ Obispo sobre los/ obsequios y respetos que deben prestar al Rey con el motivo de venir à Barna y tal vez de pasar por estal ciudad para ir a reconocer la fortaleza de Figueras $[\ldots]^{199}$

El divuit de setembre de 1802 , ja saben que el rei passarà per Girona, i els membres del capítol comencen a tenir dubtes de protocol. En cas de que aquest pugi a la catedral, discuteixen sobre si tots els integrants del capítol li han de besar la mà, essent tan nombrosos. En aquest cas, a més dels músics, s'hauria d'avisar als absents; a l'acta s'indica que el cos capitular al complet és el més nombrós de la província, el que podria ser un problema de protocol en ajuntar-se a la resta de capítols.

Itt: el $S .^{\text {or }}$ Valparis hizo la proposicion siguiente. M.I.S./ a continuacion del encargo de recibir de Barna las/ [fol. 327v] noticias que ocurran relativas à la venida de SS.M/ à Gerona y comunicarlas à S.S.I. para resolver/ en orden de los omenages, quedeben presentar el $R$. Obispo/ y el Cabildo, leyo el Sr. Obispo la adjunta Carta del Sr./ Tobia (como esta cumplido) que comunicase sus noti-/cias, y que el Cabildo no descuidase aquellas disposi-/ciones para el caso de subir SS.MM. à la Iglesial o que recibiese à besar la mano à todo el Cabildo;

${ }^{199}$ Ll.R.C. 1800-1803, 4 de setembre de 1802 , fol. $325 \mathrm{v}$. 
quel para qualesquiera de estos dos casos convendria la/ presencia de los ausentes: à esto contexte al Illmo/ que la incertidumbre de subir, ô recibir à todo el/ Cabildo, y de que nuestro Cuerpo Capitular es el mas numeroso/ de la Provincia, juntando en el dia tantos Indibiduos/ como los otros restantes Cabildos, se podia excusar/ una Convocatoria, y lo mismo por los Musicos: à lo que no replico S.S. Illma. [...]/

Res. Que para dirigir este asunto, y prevenir las/ cosas en todo acontecim. ${ }^{\text {to }}$ se nombran Comisarios à los/SS. Obreros y Secretario, que sin consultar mas/ no siendo en un caso muy necesario, iran arre-/glando desde luego este negocio. Que se insinue nada/ mas à los Canon. ausentes que regresen à la Iglesia/ si lo tienen à bien; pero q. ${ }^{e}$ à los Musicos se les/ convoque escribiendo al Maestro. lo que se hizo. ${ }^{200}$

En el llibre de resolucions entre els fols. 338 i 339, hi ha un full insert amb les instruccions generals del procediment a seguir durant la visita del rei. Els punts vuit i deu es refereixen a la música.

Ceremonial para el Recibimiento de S.M. en casol de visitar la Igla. al paso para Figueras./ [...]

$8^{\circ}$ A este tiempo los quatro Chantres empezaran/ à entonar el Responsorio, (tono octavo) que empie-/za ; elegit eum Dominus Hasta prout in Pontif.;/ y lo repetiran haste

${ }^{200}$ Ll.R.C. $1800-1803,18$ de setembre de 1802 , fol. 327. 
que el Talamo haya entrado/ el Umbral de la puerta mayor./

$9^{\circ}[\ldots]$

$10^{\circ}$ Hecho esto, los quatro Chantres (que han de ir/ en sus filas) entonaran el $\underline{T e}$ Deum, y la demas/ Musica puesta en los Organos le continuara; en la inteligencia que, apenas llegue S.M.d al Al-/tar Mayor, canten el versiculo :Te ergo que su-/mus: $y$ concluido esto el otro versiculo, $\underline{Y n}$ tel Domine speravi $[\ldots]^{201}$

Finalment, pel que fa a informacions relatives a la visita reial, en l'acta capitular del dia vint-i-cinc d'octubre de l'any 1802, hi ha la relació dels aconteixements ocorreguts. He passat directament a transcriure els fets referents a la música, la part central de la qual fou un Te Deum.

Orden del recibim. ${ }^{\text {to }}$ de S.M. en la Visita de la Cathedral/ el 23 de Octubre de 1802.: y noticias de lo que precedió./Debiendo el rey Carlos $4^{\circ}$ con los Principes y/ Rey de Etruria [...] [fol. 336]

La Musica se puso en el Coro; esto es las voces à/ un lado y los instrum. ${ }^{\text {tos }}$ a otro en las sillas altas del lado/ del Altar Mayor con facistoles cubiertos con tapicerias./[fol. 336v] [...] Asi todo dispuesto se espero el arribo de sus $M_{M} .^{e s}$ quel tardo poco en verificarse, y con el clamor de Campanas, soni-/do de Caxas Militares y Musica, se apearon del Coche al piel de la Escalera, donde el Governador y Regidores mas

${ }^{201}$ Ll.R.C. 1800-1803, fol. insert entre el 388 i el 389. 
antiguos tenian ya las baras del Talamo./[...] Hecho esto dos Chantres empezaron à cantar el Respon-/sorio del Ceremonial, y la cruz à andar siguiendo todos. [...] Luego de haber entrado el umbral de la puerta de la Igla./ S.I. tomo el Aspersorio q. ${ }^{e}$ alli tenia preparado un Ten. ${ }^{\text {te }}$ de Vicario/ y dio agua bendita à los Reyes Solos./ [fol. 337] A este tiempo los dos Chantres entonaron el Te Deum; que conti-/nuo la Musica. [...] Concluido el Te Deum el/ Sr. Obispo colocado al lado de la Epistola de frente à la del Evangelio/ y à SS. MM. arrodillados al pie de la tarima del Altar, can-/to los versitos del Ceremonial, respondiendo la Musica, y conclui-/dos dixo las oraciones del mismo Ceremonial. $[\ldots]^{202}$

\section{d) Proclamació del rei Ferran VII}

L'any 1808 , el divuit d'abril es fan rogatives per a que el rei Ferran VII governi amb encert, doncs el seu pare ha abdicat en favor seu.

Ley una carta de S.M. dirigida al Cabildo, por el Secretario de su Camara Dn. Pedro Fernano Tabina; S.M. dice quel para conseguir el acierto en el govierno de estos Rey-/nos, que han recaido en su Real Persona por renuncial de Su Augusto padre el Rey Dn. Carlos Quarto, necesita implorar el auxilio divino por medio de fervorosas ora-/ciones, y rogativas, para que este

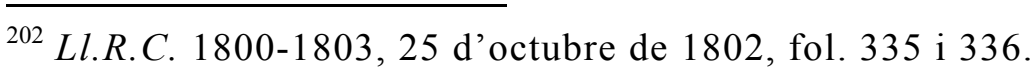


cabildo disponga sel hagan en esta Iglesia, segun en semejantes casos sel acostumbra./

Res. Que quedan nombrados Comisarios para tratar/ con el Sr. Obispo y prevenir lo necesario los SS. Tor-/rent y Ximenez [...]. ${ }^{203}$

\section{e) Assalt a la ciutat, primer setge i fugida de les tropes franceses}

El vint-i-cinc de juny de l'any 1808 , se celebra ofici i Te Deum a Sant Narcís en acció de gràcies per la victòria contra les tropes franceses, que en el dia i la nit del vint al vint-i-ú de juny volien assaltar la ciutat.

[...] celebrar el dia de mañana un Te Deum/ al glorioso Patron Sn. Narciso en accion de gra-/cias por la victoria que nos ha concedido con/ su patrocinio contra las tropas francesas, que en/ el dia y noche del 20 a 21 del corriente mes/ querian a toda fuerza asaltar nuestra Ciu-/dad, y para suplicarle humilde y rendidamentel nos continue su intercesion delante del Sr. de los/ Exercicios en lo sucesivo. Que se prescindira del todo motivo de etiquetas, caminando todos al/ glorioso fin de salvar la Patria y la Re-/ligion. Esperan la respuesta de V.S./ Res. Que el Cabildo condesciende $[\ldots]^{204}$

El dos de juliol de l'any 1808, membres de la Junta de la ciutat, proposen al capítol que se celebri un ofici amb Te Deum, l'endemà, dia tres de juliol. I també

\footnotetext{
${ }^{203}$ Ll.R.C. 1807-1812, 17 d'abril de 1808, fol. 97.

${ }^{204}$ Ll.R.C. $1807-1812,25$ de juny de 1808 , fol.121v.
} 
comuniquen que han nomenat a Sant Narcís patró generalíssim, per a que intercedeixi a favor de la ciutat, pel que fan la promesa de celebrar un ofici solemníssim el dia vint de juny de cada any. ${ }^{205}$

El Sr. Presidente propuso: M.I.S. [...] Comisionados de la Ilustre Junta de esta Ciudad esperan/ para proponer a V.S. un asunto que segun mel han confiado consiste en que dcha Ilustre. Junta/ desea celebrar un oficio con Te Deum en la Capillal de Sn. Narciso en el dia de mañana 3 de los/ corrientes, y al mismo tiempo, habiendo nom/brado al Glorioso S. I. Patron Generalisimo en/ la presente situacion con el fin de que inter-/ceda con nuestro Señor para que conceda buen exi-/to â nuestras armas espera presentarle en su/ mismo Sepulcro la Insignias que son Su espa-/da, baston y faxa. Al mismo tiempo la Ilustrel Junta ha hecho voto de celebrar un Oficio Solem-/nisimo con sermon en el dia 20 de cada año/ del mes de Junio, en el qual tan visiblemente/ nos asistio librando a esta ciudad destituidal de Socorros, y quasi desarmada de que lal asaltasen los franceses [...]/

Res. Que el Cabildo se presta gustoso â la Cele-/bracion del Oficio y Te Deum acordado por lal Junta para mañana 3 del corriente. $[\ldots]^{206}$

Davant el fort assetjament dels francesos, el vuit d'agost de l'any 1808 els membres capitulars encomanen,

\footnotetext{
${ }^{205}$ Aquest ofici se celebrarà cada any, des del 1814 fins al 1820.

${ }^{206}$ Ll.R.C. $1807-1812,2$ de juliol de 1808 , fol. $122 \mathrm{v}$.
} 
per a l'endemà, unes rogatives a la capella de Sant Narcís, sense esperar la petició de l'ajuntament.

[...] le suplica una Rogativa para el dia de mañanal a Sn. Narciso en su Capilla â fin de que Dios por su/ intercesion nos conceda la gracia de triunfar del nuestros enemigos, que nos tienen sitiados. El/ Cabildo no ha recibido oficio acerca del particu-/lar, como es de estilo y practica en tales casos,/ pero teniendo atencion â la urgente necesidad,/ y prescindiendo por ahora de etiquetas, podra V.S./ acordar esta rogativa si lo tiene $\hat{a}$ bien./

Res. Que se haga mañana esta funcion. ${ }^{207}$

El disset d'agost missa i Te Deum a la capella de Sant Narcís per haver fugit l'enemic la nit anterior, després de vint-i-cinc dies de setge.

Propuso el Presid. ${ }^{\text {te }}$ La Junta Suprema de estal Ciudad por sus Indibiduos los SS. Canonigos Cuffi y Pla/nella suplica â V.S. tenga la bondad de Cantar/ en la Capilla de Sn. Narciso un Solemne Te Deum/ en accion de gracias por haber huido en la no-/che anterior el exto. Frances, dejando libre lal Ciudad despues de 25 dias de Sitio./

Res. Que se cante esta misma mañana â las/ once. $[\ldots]^{208}$

El vint d'agost hi ha una petició del president de la junta de la ciutat, Juan Bolívar, demanant un ofici

${ }^{207}$ Ll.R.C. 1807-1812, 8 d'agost de 1808, fol. 130.

${ }^{208}$ Ll.R.C. 1807-1812, 17 d'agost de 1808, fol. 131. 
solemmne amb sermó i Te Deum a la capella de Sant Narcís, donant les gràcies per la retirada dels francesos el dia disset d'agost. I una altra funció de difunts en sufragi de les ànimes dels defensors que han mort defensant la ciutat i la pàtria. El capítol acorda realitzar aquestes funcions els dies vint-i-cinc i vint-i-sis del mateix mes. ${ }^{209}$

\section{f) Segon setge i presa de la ciutat}

Encara no ha passat un any de la retirada dels francesos, i el mes de juny de l'any 1809, hi ha una segona escomesa de les tropes napoleòniques a la ciutat, aquesta vegada amb molta més tropa.

El cinc de juny de l'any 1809, l'ajuntament demana al capítol que es realitzi un ofici de rogativa a Sant Narcís per a que els empari en aquest moment tan crític d'assetjament, per part de l'enemic.

Leyó el Sr. Presidente una Carta que le habia en/ tregado el Sindico de la Ciudad; exponiendo que el Ayuntamiento suplicaba al Cabildo tubiese la/ devocion de celebrar mañana 5 un oficio del Rogativa a Nuestro Patron y Generalisimo Sn./ Narciso implorando su patrocinio en esta oca-/sion critica, en que se halla la Ciudad Sitiada/ del enemigo. ${ }^{210}$

El vuit de juliol de 1809 , Te Deum solemne a les onze del matí per la gloriosa defensa de Montjuic, fent

\footnotetext{
${ }^{209}$ Ll.R.C. 1807-1812, 20 d'agost de 1808, fol. 132.

${ }^{210}$ Ll.R.C. 1807-1812, 4 de juny de 1809, fol. 195.
} 
endarrera l'enemic després de tres assalts, i dues hores de función terrible y sangrienta .

Propuso el S. Cuffi en nombre de la Junta del esta Ciudad, que en virtud de la Gloriosal defensa $q .^{e}$ habia hecho Monjuich, rechaIzando en la mañana de este dia al Ene-/migo despues de tres asaltos, cuya funcion/ terrible y sangrienta duro dos horas, se can-l te a las once un solemne Te Deum con mu/sica./

Res. Placet. $[\ldots]^{211}$

El set de desembre de 1'any 1809 , els representants del govern francès, ordenen al capítol que celebri un $T e$ Deum en acció de gràcies per la presa de la ciutat.

Solemne Te Deum en accion de gracias por la tomal de esta Ciudad verificada el dia 10 del corrientel

Res. Que responda que el Cabildo esta pronto a cumplir la orden $[\ldots] .{ }^{212}$

\section{g) Girona francesa}

El quinze d'agost de l'any 1810 per ordre del corregidor es fa un Te Deum en motiu de la festa de l'emperador Napoleó. Des del capítol avisen dient que per falta de veus i músics, no es podrà realitzar la funció tant bé com es desitjaria.

${ }^{211}$ Ll.R.C. 1807-1812, 20 de juliol de 1809, fol. 195.

${ }^{212}$ Ll.R.C. 1807-1812, 7 de desembre de 1809, fol. 213. 
Ley una Carta de la Municipalidad que contenial copiada una orden del Corregidor previniendo/ al Cabildo que el dia 15 del corr. ${ }^{\text {te }}$ con motivo del la fiesta del Emperador napoleón se cantarial un Te Deum en la Iglesia, y que esperaba se encar-/gase el Cabildo de prevenir lo necesario paral esta funcion que seria à las doce de dcho. dia./

Res. Que se contexte que el Cabildo estara preve-/nido para dicho dia y hora, pero que por/ falta de voces y Musicos no podra celebrar es-/ta funcion como desearia; à que se debe añadir/ la falta de otros adornos. ${ }^{213}$

El vint-i-un d'octubre de 1810 , demanen que per al dia vint-i-nou, dia del sant patró de Girona, se celebri l'ofici de Sant Narcís en la seva capella, per petició dels obrers de Sant Feliu i la municipalitat. El capítol respon dient que ja proporcionaran la música i tot el que es necessiti, per a fer la funció amb tota la pompa possible.

Itt: El S. ${ }^{\text {or }}$ Presid. ${ }^{\text {te }}$ propuso: que los Obreros de $S .{ }^{n}$ Feliu y/ Municipalidad suplican al Cabildo se haga la funcion/ acostumbrada el dia de S. ${ }^{n}$ Narciso en su Capilla; quel proporcionaran Musica y lo demas correspondiente pa-/ra que se haga esta funcion con la pompa posible./

Res. Que se responda que el Cabildo estara pronto/ el dia del S. en su Capilla para la Celebracion del/ oficio, y se nombraran Comisar.s a los SS. Oliver y Segura, que canto el oficio por su turno. ${ }^{214}$

${ }^{213}$ Ll.R.C. $1807-1812,28$ de juliol de 1810 , fol. $244 \mathrm{v}$.

${ }^{214}$ Ll.R.C. 1807-1812, 21 d'octubre de 1810, fol. 251. 
El quinze de novembre de 1810 , el corregidor ordena un Te Deum per la rendició de Tortosa.

Itt: El S. ${ }^{\text {or }}$ Intendente passo oficio al Cabildo para quel se cantase un te Deum en esta Santa iglesia/ por la rendicion de Tortosa verificada el dia/ 2 del corriente mes. ${ }^{215}$

El vint-i-sis de març de 1811, el govern francès encomana que es prepari un Te Deum per quan se sàpiga que l'Emperadriu ha donat a llum.

Ley un oficio del S. ${ }^{\text {or }}$ Tobia, que habia recibido del Gobierno,/ proviniendo que estubiese la Igl. ${ }^{a}$ dispuesta y/ à punto, para cantar un Te Deum luego llegasel la noticia del parto de la Emperatriz./

Res. Que se responda que el Cabildo dispondrá lo nece-/sario para este fin. ${ }^{216}$

L' onze d'octubre de 1812, el govern francès encomana un Te Deum al capítol per la victòria guanyada als russos, i abans una Misa baja ${ }^{217}$.

El Sr. Presid. ${ }^{\text {te }}$ dio parte al Cabildo de un oficio/ que habia recibido del Gobierno para que por àl las 11 en punto se cantase un te Deum por/la victoria ganada à los Rusos, y antes una/ Misa baja./

\footnotetext{
${ }^{215}$ Ll.R.C. $1807-1812,15$ de novembre de 1810 , fol. $260 \mathrm{v}$.

${ }^{216}$ Ll.R.C. $1807-1812,26$ de març de 1811 , fol. $267 \mathrm{v}$.

${ }^{217}$ Francesc Civil i Castellví, en el llibre El fet musical a les comarques gironines, Ob.cit., p. 16 , comenta que el terme Misa Baja és un gal·licisme provinent de Messe basse.
} 
Res. Que el S. ${ }^{\text {or }}$ Obrero avise à los oficiales de la/ Iglesia, para q. ${ }^{e}$ todo esté a punto à la horal [fol. 13] Y los SS. Comisarios de Musica prevengan al Ma-lestro de Capilla, que los Musicos esten asimismo/ prontos a cantar el $\underline{\text { Te Deum. }}{ }^{218}$

En l'acta capitular de divuit d'octubre de 1812, acorden que se celebri la funció de Sant Narcís del vint-inou del mateix mes a expenses del capítol, amb música, i a la col-legiata de Sant Feliu.

Propuse M.Y.S. Mañana es el dia de $S .{ }^{n}$ Narciso/ y convendra que V.S. disponga lo convenientel en el caso de que tenga à bien bajar a $S .{ }^{n} /$ Feliu: para su inteligencia en el año pasado sel celebró esta funcion à expensas de V.S. y en el/ anterior concurrieron varios devotos que lo pidieron a V.S. Este es un Santo de la mayor devocion de esta Ciudad [...]/

Res. Que el Cabildo se halla pronto à celebrar/ esta Funcion, y concurrir à la Colegiata pagando/ la Musica, Cera, y demás que sea necesario si aca-/so por otro medio no se puede excusar este gasto/ pues aunque el Cabildo no esta en disposicion/ de concurrir à estas expensas, los motivos releIvantes que concurren le ponen en la precaucion/de no omitir esta funcion. ${ }^{219}$

\section{h) Rendició francesa i tornada de Ferran VII}

${ }^{218}$ Ll.R.C. 1812-1815, 11 d'octubre de 1812, fol. 12v i 13.

${ }^{219}$ Ll.R.C. 1812-1815, 18 d'octubre de 1812, fol.14. 
El 1814, concretament el dia dos de maig, se celebren Te Deum a totes les esglésies amb motiu de la rendició de la cort francesa als aliats.

Te Deum en todas la Yglas [...]/ por la rendicion de la Corte de Francia Paris a las armas de los Aliados. ${ }^{220}$

El dinou de juny de 1814, se celebra un ofici a Sant Narcís, en compliment de la promesa feta l'any 1808 , per l'aixecament del setge.

El S. ${ }^{\text {or }}$ Presidente propuso: que la Ciudad tenia re-/suelto hacer una funcion à $S .^{n}$ Narciso en cumpli-/miento de la promesa del año 1808 por el le-/vantamiento del Sitio de los Franceses mandados/ por Duesme. Suplica al Cabildo asista, y pague la Musica, obligandose el Ayuntamiento a pagar la Cera y demas gastos. V.S. determinara./

Res. Que el Cabildo esta propuesto à hacer esta fun-/cion, y que los SS. Codorniu y Roca cuiden. $^{221}$

El vint-i-vuit de març de 1815, es canta el Te Deum per celebrar l'entrada del rei a Espanya, el vint-i-quatre de març de l'any anterior.

Hizo presente el $S .^{\text {or }}$ Valparis con el $S .^{\text {or }}$ Cuffi: quel en cumplim. ${ }^{\text {to }}$ de la Comision del Cabildo, para tratar con/ el S. ${ }^{\text {or }}$ Governador sobre la funcion del Te Deum, quel debe verificarse mañana 28: habian quedado con/

\footnotetext{
${ }^{220}$ Ll.R.C. $1812-1815,2$ de maig de 1814 , fol. $95 \mathrm{v}$.

${ }^{221}$ Ll.R.C. 1812-1815, 19 de juny de 1814, fol. 75 .
} 
dho. Ex. ${ }^{\text {mo }}$ que no pudiendo celebrarse los dos oficios àl causa de las ocupaciones de la Ygl. ${ }^{a}$ la misa conven.'/ se celebraria comenzando à las diez en que debia hallarsel en la Cath. ${ }^{l}$ S.E. con la oficialidad Ayuntam. ${ }^{\text {to }}$ Gremios/ y demas corporaciones con organo á Coretos; que se ha-/ria por via de oracion una narracion historica del los acontecimientos de S.M. en cautividad restiItucion a sus Reynos y Domin. ${ }^{o s} T^{a}{ }^{a}$ [?] a cargo del Can. ${ }^{\circ}$ de la Colegiata de S. ${ }^{n}$ Feliu D. ${ }^{n}$ Narciso Vifreu, y quel se cantaria por ultimo un Te Deum con la Musica y/ toda la Solemnidad posible $[\ldots]^{222}$

El vint-i-tres de juliol de 1815 , es canta un $T e$ Deum per la "memorable" victòria de les armes aliades contra Napoleó.

Te Deum por la memorable Victoria de las Armas Aliadas/ contra Napoleon $[\ldots]^{223}$

El vint-i-set d'abril de 1816, amonesten als beneficiats que no s'aixequen en el Gloria Patri dels Salms. D'aquesta acta es desprèn que un sector de membres de la capella estaven molt desencantats de la política exercida per Ferran VII, tot $\mathrm{i}$ haver estat tan desitjat durant el període d'ocupació francesa.

El Sr. Pres. ${ }^{\text {te }}$ D. ${ }^{n}$ Josef Campillo, $\ddot{y}$ D. ${ }^{n}$ Hilario Micalet/ propusieron, $q .^{e}$ muchos Residentes no se levantan en el/ Gloria Patri de los Salmos, como deven según lo preve-

\footnotetext{
${ }^{222}$ Ll.R.C. 1812-1815, 27 de març de 1815, fol. 137.

${ }^{223}$ Ll.R.C. 1815-1817, 23 de juliol de 1815, fol. 16.
} 
Inido $\ddot{y}$ mandado en las Constituciones de esta $S^{\text {ta }} \mathrm{Ygl}^{a}{ }^{a}$ en/ el numero $13, \ddot{y}$ que se rie, $\ddot{y}$ habla demasiado en el Coro: Y asi V.S. que disponga de lo necesario para reme-/diar estos defectos. I

Resolucion. Que los Sochantres cuiden de hacer callar, $\ddot{y}$ hagan ob-/servar las Constituciones de la Sta. Ygla.; $\ddot{y}$ que el $C a b .^{d o} /$ les sostendrá en lo que les pueda suceder; $\ddot{y}$ quel se lean la Constituciones en el die acostumbrado. ${ }^{224}$

També l'any 1816, el set de juliol, es canta un Te Deum per la victòria en la batalla de Wiluma, sobre els "rebels" de Buenos Aires. ${ }^{225}$

El quinze de gener de l'any 1819, es fa un ofici solemne i un funeral per la reina Isabel Maria Francesca, $i$ els dies vint-i-sis i vint-i-set de febrer es feren els funerals pels reis Carles i Maria Lluïsa. En els Llibres d'Obra, consten els pagaments fets a Ramon Bassas, instrumentista de vent-fusta, que l'any 1819 s'encarregava provisionalment de fer de mestre de capella.

Despes Extraordinari de la Obral [...]

Als 20 Janer de 1819 pagat al Rt. Ramon Bassas/ Pror. [professor] de la Capella de Musica per lo offici solem-/ne funeral de Cantá en esta Sta. Yglesia lo Diel 15 dels corrent per la Reüna de España Dna. Isa-/bel Maria Francisca... $12 \mathrm{ll}$. s./

Vera Ramon Bassas Pbre./

\footnotetext{
${ }^{224}$ Ll.R.C. 1815-1817, 27 d'abril de 1816, fol.88.

${ }^{225}$ Ll.R.C. $1815-1817,7$ de juliol de 1816 , fol. $113 \mathrm{v}$.
} 
Als 4 Mars 1819 en virtut de Polissa dels/ SS.

Canonges Comissaris per los funerals/ del Rey Dn. Carlos y Dna. Maria Lui-/sa Pagat al Rt. Ramon Bassas Pror./ del Cor de Musica per gratificació dels dies/ funerals fets en esta Sta. Igla los dias 26 i 27 del febrer proxim passat... $24 \mathrm{ll} .1 \mathrm{~s} . /$ Vera Ramon ${ }^{226}$

\section{i) Trienni Constitucional}

El quinze de març de 1820, es cantà el Te Deum per la publicació de la constitució política de la monarquia espanyola.

Se verificó en esta Sta. Ygla. la Publicacion de la Constitucion politica de la Monarquia Española, su jura-/mento y el de fidelidad a Ntro. Católico Rey el Señor D. ${ }^{n}$ Fernan-/do VII $[\ldots] /$

Entonó después el Puesto el Te Deum, q. ${ }^{e}$ cantó la Ca-/pilla de Musica de la misma Catedral. ${ }^{227}$

El set de maig de 1820, se celebra missa amb Te Deum per l'elecció de diputats.

Dia 7 de Mayo de 1820, despues de un recado del $S .{ }^{\text {or }}$ Alcalde [...]/ Se empezó la Misa de Spiritu Sancto [...]. Después de concluida la Misa se procedió á la elección de los electores de este partido, y nombrados estos,/ que fue a las 4 horas de la tarde del

${ }^{226}$ Ll.C.O. 1817-1818, fol. 112 .

${ }^{227}$ Ll.R.C. 1819-1821, 15 de març de 1820, fol. 44. 
mismo dia, entró el/ S. ${ }^{\text {or }}$ Can. ${ }^{g o} q .^{e}$ habia celebrado la Misa de Sp. Sto. el Te Deum/ acompañado de otros dos Asistentes Capitulares, $y \mathrm{M}^{\circ}$ de ceremonia, manteniendose en pié en el presbiterio del altar/ mayor, alternando el Coro con el Organo dcho canto, con/ 4 bordones al facistol de dcho coro dos S.S. Can. ${ }^{\text {gos }}$. Y dos Benef. ${ }^{\text {dos }}$, bien que faltaron otros dos de estos. ${ }^{228}$

El dinou de juny de l'any 1821 , per la precarietat de fons, s'estalvien la música de l'ofici del vot a Sant Narcís, que s'havia de celebrar l'endemà. Aquest ofici commemorava els fets ocorreguts l'any 1808 , i es venia realitzant cada any.

Dixo el Sr. Presidente, M.Y.S., Los S.S. Canonigos Administradores generales/ hacen presente: que con respecto a las circunstancias actuales/ podria ahorrarse el gasto que importaria la musica del Oficio/ del voto á $S$. Narciso del dia 20 innmediato [commemorant el 1808]; y si parecia al/ cabildo de acuerdo, y en union con el M.Y. Ayuntamiento, y no habiendo inconvenientel por dicho Ayuntamiento, po-/dria cantarse dho oficio como el de los demas votos, por el coro./

Resol. Placet $[\ldots]^{229}$

\section{j) Retorn a l'absolutisme}

${ }^{228}$ Ll.R.C. 1819-1821, 7 de maig de 1820, fol. 54.

${ }^{229}$ Ll.R.C. 1821-1823, 19 de juny de 1821, fol. 6. 
El nou de març de 1823, es canta un Te Deum, només amb cor i orgue, per haver dominat les armes nacionals els "forts" de la Seu d'Urgell.

Dixo el Sr. Secretario: M.Y.S.: Los dos SS. Regidores Dn Francisco Gau-/bert, y Dn Jayme Curós han venido á mi para que comunicase á V.S./ de parte del Sr. Gefe Politico y Alcalde $1^{\circ}$ de esta, debia mañanal cantarse un Te Deum, sin musica, con solo el organo y coro, por haberse posesionado las armas nacionales de los fuertes/ de la Seo de Urgel, el dia 3 de los corrientes, cuya funcion/ seria á las once $[\ldots] /$

Resol. Placet, $[\ldots]^{230}$

L'u d'octubre de 1825, en motiu d'esser l'aniversari de la llibertat de S.M. a Cadis, es canta un Te Deum en acció de gràcies.

El Sr. Presidente dijo: Que con motivo de ser el dia del/ [fol. 16] aniversario de la libertad de S.M. en Cadiz, estaba prevenido se cantasel un Te Deum en accion de gracias, y que habiendo pedido la hora/ [...] se podia señalar la de los tres/ cuartos para las diez./ Resolución. Placet. ${ }^{231}$

\section{k) Actes relacionats amb pontífexs}

\footnotetext{
${ }^{230}$ Ll.R.C. 1821-1823, 8 de març de 1823, fol. 26.

${ }^{231}$ Ll.R.C. $1825-1827,1$ d'octubre de 1826 , fol. $15 \mathrm{v}$ i 16.
} 
El dos de maig de l'any 1829, es canta el Te Deum per l'elecció del nou Papa Pius VIII.

Se leyo un oficio de la Real Camara, comunicando la eleccion del/ Nuevo Pontifice con el nombre de Pio VIII./

Resolución. Para inteligencia y satisfaccion, y que mañana se cante el Te Deum [...] $]^{232}$

Diumenge tretze de març de 1831, es canta el Te Deum a totes les esglésies per l'elecció del nou Papa Gregori XVI.

Se leio un oficio de la Real Camara relativo a que se cante el $\underline{\text { Te Deum/ en todas las }}$ Yglas de españa por la eleccion del nuevo Pontifice/ Gregorio XVI /

Resol. Que se cante el Te Deum el Domingo 13 del corriente; quedando/ nombrados para convidar al Sr Obispo y Sr Governador y el Ayuntamiento/ disponer lo demas concerniente para el efecto, los SS. Bertran/ y Micalet. ${ }^{233}$

Te Deum en acció de gràcies per l'elecció de nou pontífex, el Papa Pius IX, el tres de juliol de $1846 .{ }^{234}$

La darrera notícia de cant de Te Deum relacionat amb un pontífex és del vint-i-vuit d'abril de 1850, per celebrar que el Papa Pius IX s'ha salvat d'un atemptat.

\footnotetext{
${ }^{232}$ Ll.R.C. 1827-1829, 2 de maig de 1829, fol. 46v.

${ }^{233}$ Ll.R.C. 1829-1831, 10 de març de 1831, fol. 50.

${ }^{234}$ Ll.R.C. 1846-1849, 3 de juliol de 1846, fol. 2.
} 


\section{1) Te Deum relacionats amb la reina}

El trenta d'octubre de 1830 es canta el Te Deum, doncs la reina ha donat a llum el dia deu d'octubre, una robusta niña. Es tracta de la princesa Isabel, primogènita de Ferran VII i de Maria Cristina de Borbó.

Se leyo un oficio del Rey N.S. comunicando la noti-/cia de q. ${ }^{e}$ la Reyna Cristina havia dado a luz/ una robusta niña el dia 10 del corr. ${ }^{\text {te }}$ octubre. n. ${ }^{\circ}$ 90./

Res.on. Enterado el Cabildo. Com. ${ }^{\text {on }}$ a los S.S. Bertran/y Blanco p. ${ }^{a}$ ponerse de acuerdo con el Ayun-/tamiento sobre el Te Deum. ${ }^{235}$

El vint de gener de $1832^{236}$ neix la Infanta Luisa Fernanda, segona filla dels reis. Avisat el capítol de l'esdeveniment, resol que es canti un Te Deum el vint-idos de febrer.

1. ${ }^{o}$ Se leyo un ofocio del Rey N.S. ${ }^{r}$ con el que participa al Cabildo el/ parto de S.M. la Reyna, dando felizmente à luz el dia 30 de Enero del/ corriente año una robusta Ynfanta $[\ldots] /$

Resol. ${ }^{n}$ Que se cante un Te Deum $[\ldots]^{237}$

L'any 1833, pel mes de setembre, es canta el Te Deum per la "jura" de la princesa. Per acta capitular de

\footnotetext{
${ }^{235}$ Ll.R.C. 1829-1831, 30 d'octubre de 1830, fol.41v.

236 Aquesta és la data indicada als llibres d'història; a l'acta capitular s'indica el naixement en dia trenta de gener, i no en dia vint.

${ }^{237}$ Ll.R.C. 1831-1832, 22 de febrer de 1832, fol. 21.
} 
vint-i-set de setembre, sabem que el mestre Lleys composà una missa completa $\mathrm{i}$ la regalà al capítol. La jura d'Isabel com a princesa d'Astúries s'havia fet el trenta de juny de 1833 .

6. ${ }^{\circ}$ La Junta de Obsequios $p .^{a}$ los festejos echos en esta Ciudad â moti-/ vo de la Jura de la Princesa de estos Reinos ha regalado al Ca-/ bildo [...]/ una misa completa compuesta por el Maestro Lleys./

$R .^{n}[\ldots]$ que esta Misa se coloque en el ar/mario de los demas Papeles y obras Musicales, que esta en poder/ del Maestro de Capilla. ${ }^{238}$

El dia dos de desembre de 1843, Te Deum per la proclamació d'Isabel II com a "Reina Constitucional"; havia complit tretze anys $i$ es considerà major d'edat el vuit de novembre. ${ }^{239}$

El vint de febrer de 1844, es canta un Te Deum composat per Barba amb motiu del pas per Girona de la mare de la reina Isabel II, Doña Maria Cristina de Borbó. ${ }^{240}$

Les noces de la reina Isabel II amb Francisco de Asís de Borbó se celebren el deu d'octubre de 1846. Per celebrar l'enllaç de S.M., a la catedral hi ha Ofici i Te Deum el vint-i-cinc de novembre de 1846, amb composicions de Joan Carreras.

\footnotetext{
${ }^{238}$ Ll.R.C. 1833-1835, 27 de setembre de 1833, fol. $11 \mathrm{v}$.

${ }^{239}$ Ll.R.C. 1843-1846, 24 de novembre de 1843, fol. 18.

${ }^{240}$ Ll.R.C. $1843-1846,20$ de febrer de 1844, fol. 5.
} 
Se cantó una misa, partitura del profesor $D$. Juan Carreras,/ ejecutada por cuarenta músicos y dirigida por el entendido director/ de la compañía de ópera D. Pedro Donattuti, habiendo tomado par-/te en ella el tenor, baritono y bajo de la misma en union de los co-/ros. Concluido el oficio se entonó por el celebrante el Te-deum,/ composición del mismo Carreras. Cuanto se ejecutó fue de fino y es-/ quisito gusto, y á la par que merece un elogio el compositor, no son/ menos dignos de alabanza los cantantes que con tanta esactitud, so-/ nora voz y precision $[\ldots]^{241}$

L'any 1850 , el vint-i-quatre de febrer, se celebra un Te Deum per l'embaràs de la reina.

\section{m) Actes realitzats en el període constitucional i de desamortitzacions}

El vint-i-quatre de juliol de 1834 , es cantà el Te Deum per l'obertura de les Corts. ${ }^{242}$

Missa solemne i Te Deum, el quinze d'agost de 1836, per la victòria que ha obtingut el Baró de Meer capità general del Principat, sobre l'expedició de Navarra. ${ }^{243}$

El divuit de setembre de 1836, Te Deum amb orgue i cor per a l'elecció d'electors parroquials. ${ }^{244}$

\footnotetext{
${ }^{241}$ Ll.R.C. 1846-1849, llibret imprès en l'annex, fol.9.

${ }^{242}$ Ll.R.C. 1833-1835, 23 de juliol de 1834, fol. 39v.

${ }^{243}$ Ll.R.C. 1835-1837, 14 d'agost de 1836, fol.2

${ }^{244}$ Ll.R.C. $1835-1837,18$ de setembre de 1836 , fol. $38 \mathrm{v}$.
} 
El tres d'octubre del mateix any, es resol cantar un Te Deum per a l'elecció de diputats a les Corts. ${ }^{245}$

La nit del dotze d'agost de 1836, Maria Cristina restablí la constitució de 1812, després de la insurrecció de la guarnició de la Granja (real sitio de La Granja de San Ildefonso, prop de Segòvia). Arrel d'aquests esdeveniments, pel juny de 1837 es promulga una nova constitució, de caire progressista. Amb tal motiu es canta el Te Deum amb dos cors i orgue, el dia catorze de juliol de 1837.

Que el domingo proximo se celebre el oficio del accion de gracias y se entone el TeDeum/. Que esta funcion se celebre con canto/ à 2 coros y con solemnidad, y el Te-l Deum acompañado del Organo. ${ }^{246}$

El cinc de juliol de 1840, es resol cantar un Te Deum per la rendició de Morella. ${ }^{247}$

El trenta-un d'agost de 1842, es resol cantar el Te Deum per commemorar "el pronunciamiento del $1^{\circ}$ de Septiembre de 1840" , amb orgue i cant, sense instruments. ${ }^{248}$

El trenta de juliol de 1843, Te Deum per celebrar el "Glorioso pronunciamiento" (entrada a Madrid de les

\footnotetext{
${ }^{245}$ Ll.R.C. 1835-1837, 3 d'octubre de 1836, fol. 39v.

${ }^{246}$ Ll.R.C. $1837-1840,14$ de juliol de 1837 , fol.4

${ }^{247}$ Ll.R.C. $1840-1843,5$ de juliol de 1840 , fol. 1 i $1 \mathrm{v}$.

${ }^{248}$ Ll.R.C. 1840-1843, 31 d'agost de 1842, fol.
} 
tropes comandades pels generals Serrano, Narváez i Aspiroz). Les actes diuen que es cantà una missa solemne, acompanyada per una orquestra de quaranta músics, seguida del Te Deum; ambdues obres eren composicions noves i dedicades per a la funció, del compositor i mestre de capella Josep Barba.

[...] celebrandose en la Sta. Iglesia Catedral, una Misa solemne acompañada por una orquesta de 40 musicos, en seguida el TeDeum en accion de gracias, siendo ambas composiciones nuevas y dedicadas para esta funcion por el célebre Maestro de Capilla D. José Barba. ${ }^{249}$

${ }^{249}$ Ll.R.C. 1843-1846, 30 de juliol de 1843, fol.1 i 1v. 


\section{COL'LABORACIONS DE LA CAPELLA DE MÚSICA AMB ENTITATS I INSTITUCIONS RELIGIOSES}

\section{a) Parròquies, convents $\mathrm{i}$ comunitats religioses de la ciutat}

A través de la informació estudiada, em consten quatre comunitats, que són les que cada any demanen permís per a realitzar processons. Aquestes comunitats són: la de carmelites calçats, la de carmelites descalces, la de mercedaris i l'ordre tercera de Sant Francesc. A continuació transcric els documents que donen fe d'aquestes comunitats.

Carmelites calçats,

Itt: Ley otro Memorial de la R. Comunidad de Carmelitas/ Calzados pidiendo licencia para hacer la Procesion/ el dia de N.S. del Carmen del mismo modo, y por las/ mismas Calles, que la hicieron el año pasado./

Res. Que el cabildo [...] concede esta licencia $[\ldots]^{250}$

Carmelites descalces,

Propuse: M.I.S. La Comunidad de Carmelitas Descalzas y la de Mer-/cedarios piden licencia para hacer sus Procesiones por me/dio de Memoriales que han presenta, [...] Res. Se concede licencia $[\ldots]^{251}$

\footnotetext{
${ }^{250}$ Ll.R.C. 1800-1803, 6 de maig de 1802, fol. 295 v.

${ }^{251}$ Ll.R.C. 1800-1803, 26 d'abril de 1802, fol. 290.
} 
Comunitat de mercedaris,

Itt: Ley dos memoriales, uno de la Comunidad de la Mer-/ced pidiendo licencia para Procesiones

Res. Concedida la licencia a la $R$. Comunidad de la Merced/ [... $]^{252}$

Tercera ordre de Sant Francesc,

Prim. $^{\text {te }}$ : Ley un Memorial del Comisar. ${ }^{o} y$ Ministrol de la Tercera Orden de Sn Francisco pidiendo permi-/so para hacer la Procesion acostumbrada el/ martes de Semana Santa./

Res. Que se concede esta licencia, y que esta procesion/ se haga por las calles acostumbradas en otros años. ${ }^{253}$

Itt: Ley otro Memorial de el Minist. ${ }^{o} y$ Comisario de la or-/den tercera de $S$. Francisco para hacer la procesion del/ Via Crucis el dia que corresponde en esta Quaresmal

Res. concedida, debiendo seguir la carrera acostum-/brada en los años anteriores. ${ }^{254}$

Pel que fa a convents, hi havia relacions amb el convent de Sant Daniel fora muralla, i el convent de Sant Josep.

${ }^{252}$ Ll.R.C. $1803-1807,15$ d'abril de 1805 , fol. $365 \mathrm{v}$.

${ }^{253}$ Ll.R.C. 1800-1803, 20 de març de 1802, fol. 278.

${ }^{254}$ Ll.R.C. $1800-1803,5$ de març de 1803 , fol. $355 \mathrm{v}$. 
Relacionat amb el convent de Sant Daniel, vegi's el document transcrit en l'apartat que tracta la coincidència de dues o més funcions religioses ${ }^{255}$, ja que en alguns casos la capella anava a realitzar actes en aquest convent.

En el mateix document citat en el paràgraf anterior, també es diu que alguns membres de la capella anaren a celebrar una novena al convent de Sant Josep. A més d'aquest acte, la comunitat del convent de Sant Josep, demanava cada any permís per a la processó del mes d'abril.

Itt: Propuse con este motivo; Bernardo BerItran Musico y el convento de S. ${ }^{n}$ Joseph piden/ licencia aquel para salir por motivo de indispo-/sicion; la Comunidad para hacer Procesiones./

Res. Concedido uno y otro. ${ }^{256}$

\section{b) Parròquies, convents i comunitats religioses de fora de la ciutat}

En la documentació consultada, cada any apareix el memorial d'alguns membres de la capella i un o dos escolans, per anar a celebrar el novenari de la Mare de Déu dels Àngels, al monestir de Sant Feliu de Guíxols.

Ley un Memorial del R. P. Isidro Hernandez Monge del/ Monasterio de $S .^{n}$ Feliu de Guixols suplicando al Cabildo per-/mita pasar à aquella Villa uno de los Infantes del

\footnotetext{
${ }^{255}$ En aquest mateix capítol, apartat 2 a.

${ }^{256}$ Ll.R.C. $1800-1803,18$ d'abril de 1803 , fol. $367 \mathrm{v}$.
} 
Coro para celebrar con mayor Solemnidad el Novenario/ de N.S. de los Angeles, que cada año se celebra pasada/ la festividad de los Reyes./

Res. Que condesciende el Cabildo à la Suplica del Monas-/terio, y que el Maestro de Capilla quede encargado de nom-/brar el que le pareciere. ${ }^{257}$

En aquest segon document hi figuren a més, els músics que sol-licitaren anar a Sant Feliu. Eren tots tres seglars, el contrabaixista Miquel Albert, el violinista Carles Quilmetas i el trompa Tomàs Blanc. El capítol sempre posava molts entrebancs per a que els músics clergues beneficiats, sortissin de la catedral. ${ }^{258}$

Primeramente: Leí un Memorial del Padre Fr. Isidrol Hernandez Sacristan del Monasterio de Sn Feliu de Guixols, suplicando al/ Cabildo diese permiso à uno de los Infantes de Coro/ para pasar à dicha Villa con motivo de un Novenario/ que celebran despues de Reyes. Al mismo fin pre-/sentaron Memoriales los Musicos Seculares Albert,/ Quilmetas, y Blanch sobreque V.S. vistará. ${ }^{259}$

\footnotetext{
${ }^{257}$ Ll.R.C. 1800-1803, 5 de desembre de 1801, fol. 262.

258 Vegi's en en capítol III, apartat dels xantres, com el capítol denega el permís d'anar a Sant Feliu de Guíxols al xantre Lleó Antoni Santamaria.

${ }^{259}$ Ll.R.C. 1803-1807, 29 de desembre de 1803 , fol. $37 \mathrm{v}$.
} 


\section{ACTES DEMANATS PER L'AJUNTAMENT ${ }^{260}$}

Els actes relacionats amb Sant Narcís, patró de la ciutat molt estimat encara ara pels gironins, sempre els pagava l'ajuntament. Cada any hi havia dues celebracions relacionades amb el patró. La primera era una processó el dia de Sant Narcís del mes de març.

El Sindico en nombre del Ayuntamiento pidio dia para/ hacer la Procesion de S. ${ }^{n}$ Narciso/ Res. Que en el mismo dia del Santo si el tiempo lo permite. ${ }^{261}$

El segon acte relacionat amb el patró de la ciutat era, per la festa $\mathrm{i}$ fires de St Narcís el dia vint-i-nou d'octubre, que ha perdurat fins als nostres dies.

Itt: El Sr Presidente propuso: que los Obreros de $S .^{n}$ Feliu y/ Municipalidad suplican al Cabildo se haga la funcion/ acostumbrada el dia de S. ${ }^{n}$ Narciso en su Capilla; quel proporcionaran Musica y lo demas correspondiente pa-/ra que se haga esta funcion con la pompa posible./

Res. Que se responda que el Cabildo estara pronto/ el dia del S. ${ }^{\text {to }}$ en su Capilla para la celebracion del/ oficio, y se nombraron Comisarios a los SS. Oliver y Segura, que canto el oficio por su turno. ${ }^{262}$

\footnotetext{
${ }^{260} \mathrm{~S}$ 'han tingut en compte els actes que eren sol-licitats cada any, en condicions normals. Els actes sol-licitats per circumstàncies bèl-liques, o fets extraordinaris, ja són tinguts en compte en altres apartats d'aquest capítol.

${ }^{261}$ Ll.R.C. $1800-1803,15$ de març de 1803 , fol. 358.

${ }^{262}$ Ll.R.C. 1807-1812, 21 d'octubre de 1810, fol. 251.
} 
L'ajuntament també sol-licitava i pagava cada any la processó de l'Àngel.

Itt: El Sindico de la Ciudad pidio de parte del Ayuntamientol dia para hacer la Procesion del Angel./

Res. [...] que digere al Ayuntamiento que el dia mis-/mo se haria la procesion à las nueve y media. ${ }^{263}$

Segons l'acta capitular del dia cinc de maig de l'any 1820, l'ajuntament sol-licità els quatre escolans de la capella, per a que cantessin unes cobles patriòtiques en l'acte d'inauguració de la Placa de la Constitució, a la porta principal de la Casa de la Vila.

$2^{\circ}$ Pidió igualmente el Sor. Presid. ${ }^{\text {te }}$ al Cab. ${ }^{d o}$ p. ${ }^{a} q .{ }^{e}$ se prestase à en-/viar 4 Monacillos de coro, como los habian pedido los S.S. del/ Ayuntam. ${ }^{\text {to }}$, p. $^{a}$ cantar unas coplas patrioticas en la susodicha funcion/ de descubrim. ${ }^{\text {to }}$ de la Lapida de la Constit. ${ }^{\text {on }}$ colocada en la Puerta Principal de la Casa Consistorial./

Resol. ${ }^{n}$ Que vayan, pero sin bonete, ni batas de coro. ${ }^{264}$

${ }^{263}$ Ll.R.C. 1803-1807, 30 de setembre de 1802, fol. 329v.

${ }^{264}$ Ll.R.C. 1819-1821, 5 de maig de 1820, fol. 53. 


\section{COL·LABORACIONS DELS MÚSICS DE LA CATEDRAL EN ACTIVITATS MUSICALS CIVILS}

\section{a) Les acadèmies}

Trobem el mot acadèmia amb les dues vessants, l'una com a establiment on es practica la docència, com és el cas de la de Sant Tomàs, i l'altra com a reunió en una casa particular de músics amateurs.

L'any 1802, l'acadèmia de Sant Tomàs demana llicència per a fer la processó en honor a Sant Tomàs d'Aquino. Aquest fet es donarà també en anys successius.

Propuse: M.I.S. la Academia del S. Thomas ademas de la licencia para hacer mañanal la procesion del Santo pide quatro Bordones y otras/tantas Capas./

Res. Se concede licencia $[\ldots]^{265}$

El dia dos de març de l'any 1822, el fill gran del marquès de Campmany, demana al capítol que li deixi el contrabaix per a les acadèmies de música que celebren a casa seva, tots els dissabtes de quaresma, amb músics afeccionats $^{266}$. Gràcies a aquesta acta capitular tenim constància d'acadèmies a la ciutat de Girona. Entenent per acadèmies els concerts per a familiars i cercles d'amistats, celebrats a les cases de famílies benestants, nobles o burgeses, per al gaudi de la música, al marge de les funcions musicals celebrades en els temples i de les

\footnotetext{
${ }^{265}$ Ll.R.C. 1800-1803, 24 d'abril de 1802, fol. 190.

${ }^{266}$ Aquest document està transcrit en l'apartat de contrabaix del capítol I.
} 
òperes, que se celebraven en els teatres. Pel fet de demanar el contrabaix al capítol, és molt probable que en aquestes acadèmies o concerts, a més de músics afeccionats hi assistissin músics de la capella, tenint en compte que eren els més reputats de la ciutat i rodalies. Pel que fa al marquesat de Campmany era un títol creat a favor d'Ignasi Sabater Meca i Vilanova sobre la baronia del mateix nom; aquest marquès, segons l'acta, vivia en un casal de Girona.

Donada la proliferació d'acadèmies en les principals ciutats europees ${ }^{267}$ entre finals del segle XVIII i principis del XIX, cal pensar que les acadèmies del marquès de Campmany, no eren les úniques que se celebraven a la Girona de principis del vuit-cents. És bastant rellevant que 1'organista Antoni Guiu dediqui la seva obra Yntroducción y Variaciones para Flauta, Piano $y$ Fagote obligados, a Miquel de Foixà. Aquest personatge molt bé podria ser el baró de Foixà, el tinentcoronel Narcís de Foixà i de Miquel, mort l'any 1866, és molt probable que li encomanés l'obra per a una acadèmia celebrada a casa seva.

\section{b) El teatre}

El capítol de canonges de la catedral veia amb molt mals ulls que els músics de la capella tinguessin alguna participació en el teatre. Com deia l'ordinació segona per conservar la decència de la capella, els músics $s$ 'abstindran de tocar en saraus, balls $i$ altres indecens. ${ }^{268}$

\footnotetext{
267 Per veure diverses informacions d'acadèmies celebrades a Barcelona vegi's VILAR, Josep $\mathrm{M}^{\mathrm{a}}$. Les simfonies de Carles Baguer, Ob.cit., p.166-170.

268 Vegi's les ordinacions de la capella de música, en l'apartat pautes de funcionament, del cap.II.
} 
Tot i aquesta normativa, el mestre Josep Barba no se'n va poder estar de dirigir els assajos i preparar els músics quan una companyia de cantants italians s'installa a Girona. Segons Miró Bachs, gràcies al mestre Barba, estrenaren al teatre de la ciutat Hernani, Norma Lucía di Lamermoor i el Barbero de Sevilla ${ }^{269}$.

A petició de l'ajuntament, Barba dirigia els assajos i muntava les obres, fent els arranjaments de les òperes $i$ cercant els músics necessaris. El violinista Francesco Berini era el qui dirigia les funcions davant el públic. A més, fou contractat per l'ajuntament per ensenyar violí a sis joves de la ciutat d'origen humil. ${ }^{270}$

Aquest fet li proporcionaria molts disgustos amb el capítol de canonges, amb el qual ja no hi havia massa bones relacions. ${ }^{271}$ L'ajuntament, que havia estat el principal patrocinador d'aquestes funcions, no es volgué posar en contra del capítol, i anà també contra Barba. Finalment, l'any 1849 , es veié obligat a renunciar a la plaça de mestre de capella, passant a Santa Maria del Mar. $^{272}$

${ }^{269}$ MIRÓ BACHS, Antoni. Cien músicos célebres españoles,Ob.cit.

${ }^{270}$ La informació de Francesco Berini està extreta de GREGORI CIFRÉ, Josep M., "El Barón Melcior de Ferrer i de Manresa (18211884), un compositor catalán del romanticismo", Revista de Musicología, XIV (1992), ps.435-438.

${ }^{271}$ Vegi's en el capítol II, en l'apartat dedicat al mestre Barba, la discussió que tingué amb alguns músics de la capella, el dotze d'agost de 1838, i l'amonestació rebuda.

272 Per a més informació d'aquest procés, vegi's l'apartat del mestre Barba en el cap. III. 


\section{PERÍODES DE CRISI EN EL FUNCIONAMENT DE LA CAPELLA}

Durant el període objecte d'estudi, es comprova el davallament del poder econòmic i social de l'estament eclesiàstic. Aquesta davallada, en el cas que ens ocupa, té com a conseqüència el desmantellament de la capella de música. La institució, havia tingut un funcionament quasi estàtic a través de segles i es troba en el segle XIX, ferida de mort en el que serà el seu procés de definitiva desaparició.

En aquesta etapa, ens trobem principalment amb tres períodes de crisi o de davallament de la capella de música. La primera crisi ve determinada pels setges de 1808 i 1809. La segona crisi arriba emmarcada pel canvi polític que es produeix amb el Trienni Constitucional. La tercera té altra vegada un component polític amb la fi de l'absolutisme, i el període de les grans desamortitzacions de Mendizábal i Madoz.

\section{ELS SETGES DE LA CIUTAT}

Durant els setges de la ciutat Girona, per part de l'exèrcit francès, els anys 1808 i 1809, es produeix un fort declivi de les activitats musicals de la capella. Mentre duren els setges, la capella quedarà quasi totalment desmantellada. La situació millora una miqueta quan els setges fineixen, però el funcionament normal no es restableix fins que acaba la invasió francesa, l'any 1814 .

Passant a fets puntuals, durant els setges molts músics eclesiàstics i laics, passaren a la lluita activa, per impedir l'ocupació de la ciutat per les tropes franceses. Aquest fou el cas de l'organista Antoni Guiu, i també el dels 
germans Pere i Joan Illa, músics seglars, que entraren a servir de músics en el "B. Terci de Girona", o primer terci de Miquelets $^{273}$. Ateses les dificultats que travessava el capítol, molt pocs músics cobraren la terça del dia ú de juny al trenta de setembre de l'any 1809 ,

Porcionarios de la Capilla de Musica tanto/ clerigos como seculares â cargo de la Obra han soli/citado la tercia [...]. El Obrero ha satisfecho dicha ter-/cia â alguno de los clerigos mas utiles y residentes/ pero no a todos y menos â los seglares $[\ldots]^{274}$

Per a les funcions de Setmana Santa de l'any 1810 calgué proveir-se de músics de fora la capella, degut al gran nombre d'absents. ${ }^{275}$

Les coses no anaven gens bé per als músics laics, que el mes d'agost del 1811, per les grans dificultats econòmiques que pateixen, es veuen obligats a suplicar al capítol que els tornin a donar la feina $\mathrm{i}$ el sou que tenien. La carta la signen els músics seglars més antics, que eren Francesc Ortiz, Romualdo Huguet i Carles Quilmetas. Vegeu pel cas el següent document:

M.Y.S. ${ }^{\text {or }}$,
Fran. $^{\text {co }}$ Ortiz, Romualdo Huguet, $\ddot{y}$ Carlos
Quilmetas,/ Musicos de esta Santa Ygl. ${ }^{a}$
Cathedral de esta Ciudad,/ con la devida
veneracion hacen presente â V.S. que/ de esta

${ }^{273}$ Ll.R.C. 1807-1809, 28 de gener de 1809, fol. 162. Per consultar el document transcrit, vegi's l'apartat 3.b.3 "Els músics de vent" volum II.

${ }^{274}$ Ll.R.C. $1809-1812,4$ de gener de 1810 , fol. $213 \mathrm{v}$.

${ }^{275}$ Vegi's en aquest matix capítol, dins l'apartat titulat “Composició general de la capella", el punt 4. 
parte de dos años, de la entrega de esta Ciu. ${ }^{d}$ se hallan, sin gozar por disposicion de V.S. del/ salario que se dignó concederlos, $\ddot{y}$ que del muschíssimos años estaban disfrutando en estal santa Ygla, $\ddot{y}$ haver cumplido siempre exactam. ${ }^{\text {te }} /$ en todas las funciones que han ocurrido en ella, / con el esmero, puntualidad, $\ddot{y}$ zelo, $q .{ }^{e}$ consta $\hat{a}$ V.S./ $\ddot{y}$ ahora por no tener ningun refugio ni albitrio/ para poder trabajar de sus oficios, $\ddot{y}$ no poder sus-/tentar sus casas $\ddot{y}$ familias, que hasta al presentel han pasado con muchíssimo trabajo; Y tambien so-/licitan $\ddot{y}$ hacen presente $\hat{a}$ V.S. la parte del Sa-/ lario y Porrata, q. ${ }^{e}$ no han cobrado de la Tercial del Sep. ${ }^{\text {bre }}$ de 1809; Por tanto, acudiendo a la beInefica compasion de V.S.: Suplican rendidam. ${ }^{\text {te }}$ se sirva dispensarles la gracia de bolverlos dicho/ salario, que estaban gozando antes; ô lo quel sea del agrado de V.S. que lo recibiran por/ singular favor del acreditado Zelo de V.S. ${ }^{a}$./

Gerona 28 Agosto 1811/ Fran. ${ }^{c o}$ Ortiz Romualdo Huguet/ Carlos Quilmetas. ${ }^{276}$

Davant aquesta petició el capítol decideix donar quinze 1liures barceloneses a cada músic, en concepte d'almoina. I tot i no poder-los contractar anualment, el capítol es compromet també a avisar-los per a algunes funcions,

per via de limosna o socorro voluntario/ ia $q .{ }^{e}$ carecen de salario desde ráo/ Junÿ de 1809, pagantles sols lo $q^{e}$ traballan $[\ldots]^{277}$

\footnotetext{
${ }^{276}$ Ll.R.C. 1807-1812, annex $\mathrm{n}^{\circ} 3$.

${ }^{277}$ Ll.C.O. 1811-1813, 31 d'agost de 1811, fol. 139.
} 
Les coses eren una mica millor per als músics clergues beneficiats, però així i tot, l'any 1813 dels tretze beneficis que hi havia habitualment a la capella, només en queden set.

Numero dels Resid. ${ }^{\text {tes }}$ de la Igla. y Cathl. de Gerona que en/ el dia se troban presens y en actual residencia. Octubre/ 12 de 1813./

Anton Santamaria./ [xantre]

Joan Terres/ [xantre]

Jph Guimat./ [flauta, fagot i oboè, amb obligació d'alfuller]

Anton Guiu./ [organista]

Rafael Compte./ [mestre de capella]

Narcis Vivern./ [flauta, fagot i oboè, amb obligació d'alfuller]

Domingo Ferrer. ${ }^{278}$ [tenor i alfuller]

La situació de la capella de música no es normalitza fins el 1814, doncs a partir del mes de maig les tropes napoleòniques es comencen a retirar. Tornen a contractar els músics seglars més antics, de manera que el trenta de setembre del 1814 ja poden cobrar la primera terça. Als músics seglars més joves, com els germans Pere i Antoni Illa, no se'ls readmetrà fins el vint-i-vuit de gener del 1815 .

M'ha semblat interessant reproduir alguns dels fets que apareixen en els llibres de resolucions capitulars, relatius a la vida musical de la catedral durant els setges, doncs constitueixen un magnífic diari testimonial del que ocorregué en aquelles dates, i com es visqueren des del capítol catedralici. Aquests extractes apareixen en l'apèndix documental d'aquest capítol.

${ }^{278}$ Ll.R.C. 1812-1815, fol. solt, vertical, insert entre els fol. $228 \mathrm{v}$ i 229. 


\section{EL TRIENNI CONSTITUCIONAL (1820-1823)}

El segon període en què hom pot observar una crisi o davallament en el fet musical de la catedral, es produeix durant el període conegut històricament com a Trienni Constitucional, que comprèn els anys 1820-1823. Aquest període fou el pròleg de les grans desamortitzacions; el delme fou reduït a la meitat i l'estat posà en venda els béns del clergat. La falta d'efectius de l'església, propicià immediatament una reducció del fet musical a la catedral. El 1823, amb la intervenció de la Santa Aliança, es tornà a l'antic règim, i es revertiren les propietats desamortitzades a l'església; aquest fet ocasionà el retorn dels instrumentistes i cantors a la capella de música. Per tant fou una crisi temporal, tot i que premonitòria.

Però anem a veure amb més detall el que anà succeint durant aquests tres anys. El quinze de març de $1820^{279}$ el capítol rep la notícia que s'ha publicat la Constitución Política de la Monarquia Española, motiu pel qual la capella de música entona un Te Deum. Els efectes de la nova constitució, però, no es faran sentir fins al mes de juny del 1821. Efectivament, el dia dinou, comencen els estalvis, el capítol es veu obligat a prescindir dels instruments, en un ofici que des del 1814 havia estat instrumental i coral.

Dixo el S. ${ }^{\text {or }}$ Presid. $^{\text {te }}$, M.Y.S., Los S.S. Can. ${ }^{\text {s }}$ Administrad.s grales/ hacen pre. ${ }^{\text {nte }}: q^{e}$ con respecto a las circunstancias actuales/ podria ahorrarse el gasto $q .^{e}$ importaria la musica del Oficio/ del voto á S. Narciso del dia 20 innmediato [commemorant el 1808] ;y si parecia al/ cabildo de acuerdo, y en union con el M.Y.Ayuntam. ${ }^{\text {to }}$, $/$ y no habiendo inconveniente por dcho Ayuntamiento, po-/dria cantarse dho.

${ }^{279}$ Ll.R.C. $1819-1821,15$ de març de 1820. 
oficio como el de los demas votos, por el coro./ Resol. $^{n}$ Placet $[\ldots]^{280}$

No gaire dies més tard, el trenta de juny, el capítol es troba amb la promulgació de noves lleis per part d'hisenda, que redueixen el delme eclesiàstic a la meitat, i aboleixen altres rendes de les que sempre havia pogut gaudir, per la qual cosa es queden pràcticament sense fons.

El fons s'exhaureix definitivament a finals d'agost de 1821, data en què es despatxen tots els músics i els tres escolans que quedaven a la seu, acordant que se'ls pagarà, retroactivament des del primer dia de juny, per cada funció realitzada,

4. ${ }^{\circ}$ Los S.S. Comisionados $p .^{a}$ la economia de esta Sta. Ygla ha-/cen pren. ${ }^{t e}$ à V.S., q. ${ }^{e}$ respeto á no haber fondo alg. ${ }^{o}$ dis-/ponible $p .^{a}$ la manutencion de los Monacillos de Coro,/ desde el 1. ${ }^{o}$ del proximo sept. ${ }^{\text {bre }}$, debe V.S. resolver lo/ $q .{ }^{e}$ le parezca conveniente, $[\ldots]$ /

Resol. ${ }^{n}$ Se despachen todos los Musicos por los SS. Canon. ${ }^{s}$ Comisarios advir-/tiendoles $q .{ }^{e}$ tan solam. ${ }^{\text {te }}$ se les pagarán los dias en $q^{e}{ }^{e}$ desdel el 1. ${ }^{\circ}$ de Junio ultimo hayan trabajado en esta Sta. Ygla, pa-/gandoles igualm. ${ }^{\text {te }}$ en los $q .{ }^{e}$ sucesivamen. ${ }^{\text {te }}$ trabajaren, al/ modo con $q^{e}{ }^{e}$ se les paga en las funciones de las demas Yglas/ de esta Ciudad./ En los oficios en los terceros Domingos, y de Coretos solo sel emplearán los Musicos Eccos. Ygualm. ${ }^{\text {te }}$ se despacharán ál los tres ultimos Ynfantes de Coro; y el más antiguo pasará ál Escolan de los SS. Canonigos, el q. con Mathias tendra la/ oblig. ${ }^{n}$ de servir las Misas á los SS. Can. ${ }^{s}$, de

${ }^{280}$ Ll.R.C. $1821-1823,19$ de juny de 1820 , fol. 62 . 
comenzar ó/ tocar las antifonas en el Coro, y llevar los Candeleros, $q .^{d o} /$ sea menester, quedando señaladas $100 \mathrm{ll}$. anuales $p^{a}{ }^{a}$ sus/ salarios de cada uno de los dos. De los demas Escolanes de la/ Sacristia Capitular solo quedaran Marés y Veguda./ Desde el 1. ${ }^{\circ}$ de Sept. ${ }^{\text {bre }}$ proximo se darán dos pesetas diarias al/ S. ${ }^{\text {or } \quad M t r o . ~ d e ~ C a p i l l a ~ i n t e r i n a m . ~}{ }^{\text {te }}[\ldots]$ / $/$

2. ${ }^{\circ}$ Presentan á V.S.Y. la lista, ó nota de las funciones he-/chas por la Capilla de Musica de esta Sta Ygla., desde 1. de Junio/ ultimo hta. el dia pren. $^{\text {te }}$, con el coste de ellas, que sumal $223 l l$ 8s 6., p. $^{a}$ q. $^{e}$ V.S.Y. resuelva, si se les entregará dha par-/tida. ${ }^{281}$

Tot i aquesta resolució, l'obra no disposa de fons, i acaba donant, per via de gratificació, quatre duros á cada un dels Músics i Cantors, comprès el Mestre de Capella; doncs no s'espera poder-los donar res més en aquesta pròxima terça. ${ }^{282}$

La capella ha quedat reduïda a la mínima expressió; només resten el mestre, l'organista i el manxador, els quatre xantres, tres alfullers, l'escolà més antic, per fer d'escolà dels canonges, i els dos campaners. El vint-i-vuit de setembre, xantres, alfullers i organista demanen que se'ls socorri. En la mateixa sessió els comissaris de música, fan la observació que no cal que el mestre de capella composi noves obres.

El nou de novembre, xantres, alfullers i organista, ja no poden més, doncs no estan cobrant res, nada perciben por razon de sus trabajos, [...] ya no pueden mantenerse. ${ }^{283}$

\footnotetext{
${ }^{281}$ Ll.R.C. 1821-1823, 25 d'agost de 1821 , fol. $71 \mathrm{v}$.

${ }^{282}$ Ll.R.C. 1821-1823, 31 d'agost de 1821, fol. $72 \mathrm{v}$.

${ }^{283}$ Ll.R.C. 1821-1823, 9 de novembre de 1821, fol. 80v.
} 
La resposta és que el capítol està esperant cobrar alguna cosa de la Junta Diocesana.

El quinze de desembre diuen al mestre de capella que a partir de l' $\mathrm{u}$ de gener deixaran de pagar-li les dues pessetes diàries que li havien anat donant durant els quatre últims mesos, per la qual cosa el mestre Lleys es veu obligat a marxar.

Els diners promesos des de la Junta Diocesana, no arriben. Durant l'any 1822, els pocs músics que queden fa temps que no perceben res i es van despedint del capítol, a través de permisos, al·legant raons diverses. L'organista Antoni Guiu, diu que està malalt, i acompanyat de Miquel Fossalba, alfuller, marxen cap a França. Jaume Virosta, xantre, marxa un any a Sant Joan de les Abadesses reclamat pel govern. Al cap d'un temps marxarà també el seu germà Ramon, per la malaltia de la mare. En Francesc Roure, alfuller, marxa per quatre mesos. A l'escolà Ramon Solà, el passa a buscar el seu pare i la seva plaça serà ocupada per en Joan Carreras.

Estem al gener del 1823 i a la catedral hi queden els xantres Antonio Santamaria i Miquel Ferrer; en Francesc Creuet, que és tenor però s'ocupa de l'orgue; el manxador Baró i l'escolà Joan Carreras.

El període constitucional acaba l'abril de 1823, època en què es torna a l'absolultisme. A partir d'aquesta data la situació dels músics clergues de la capella de música canvia radicalment. Així doncs el vuit d'agost, el mestre de capella Joan Lleys, comunica que està disposat a tornar, i demana al capítol si es formarà l'escolania. En aquesta data, també es convoquen edictes per a proveir dues places d'alfuller, annexes als instruments de violí i viola. El tretze d'agost, han passat cinc dies; Lleys torna amb sou, casa i llibertat 
per a triar quatre escolans de $\operatorname{cor}^{284}$. També tornen a donar el sou a Carles Quilmetas, segon primer violí, que ja porta més de cinquanta anys al servei de la capella de música. ${ }^{285}$

El desig de tornar a la normalitat pel que fa al culte és ben palès en la sessió capitular del vint-i-quatre d'octubre del 1823, doncs escriuen el següent:

Estando ya corriente la administ. ${ }^{n}$ de las rentas de las fundaciones de esta/ Sta. Ygla [...]/ en una palabra: que vuelvan las funciones de/ esta Sta Ygla Cat. ${ }^{l}$ en el modo y forma q. estaban/ en el año 1820./ Resol. ${ }^{n}$ : Placet, y se comience el $1 .^{\circ}$ del proximo Noviembre. ${ }^{286}$

Per a restablir la música els falten dos membres importants, l'organista Antoni Guiu i l'alfuller Miquel Fossalba. Són reclamats el dia dotze de desembre: cal que tornin o que renunciïn a la plaça. ${ }^{287}$

No obstant, als músics seglars, no se'ls torna a admetre amb pensió anual fins el dia 1 de juny de 1825 , i amb els sous rebaixats.

\section{LES GRANS DESAMORTITZACIONS (1836-51)}

El període conegut històricament com a Dècada Ominosa acaba el 1833 amb la mort de Ferran VIIè. Amb la fi de l'absolutisme comença el procés del desmantellament de la capella de música. La constitució s'aprova el quinze

\footnotetext{
${ }^{284}$ Ll.R.C. $1823-1825,13$ d'agost de 1823 , fol. $14 \mathrm{v}$.

${ }^{285}$ Ll.R.C. 1823-1825, 14 de setembre de 1823, fol. 21.

${ }^{286}$ Ll.R.C. 1823-1825, 24 d'octubre de 1823, fol. $31 \mathrm{v}$.

${ }^{287}$ Ll.R.C. $1823-1825,12$ de desembre de 1823, fol. 38.
} 
de gener del 1834, i l'any 1836 comença la desamortització de Mendizábal, posant en venda els béns d'ordres regulars $\mathrm{i}$ seculars, i suprimint les vinculacions i delmes de forma completa. A partir d'aquest moment la crisi de la capella és ja definitiva, fins a desaparèixer per decret el catorze d'octubre del 1842, data en què se suprimiran totes les capelles de música.

Tot i estar suprimida la capella, de l'any 1842 al 1850 se segueixen realitzant algunes funcions de música, amb els pocs individus que queden a la catedral, que són un salmista, doncs ja no queda cap xantre, el mestre de capella, dos escolans de cor, l'organista i el manxador.

Vaig a fer l'anàlisi dels esdeveniments per parts.

Davant la falta de recursos econòmics, el capítol acomiada tots els músics seglars i la major part dels beneficiats. El quatre d'agost de 1837 el Capítol no disposa de fons i acorda suprimir el que sigui necessari. El set d'agost del 1837, se suprimeixen tots els individus de la capella de música exceptuant el mestre de capella, els quatre xantres, l'organista i els alfullers; d'escolans ja només en quedaven dos.

En vista de que el cabildo no cuenta con/ rentas ni fondos seguros para sostener/ el culto en este corriente año, acordól dar omnímodas facultades á la Comision/ de Hacienda para que por sí y ante sí, segun/ [fol. 7] le sugiriesen su celo y prudencia, y sin/ dar cuenta á Cabildo hiciesen cuantas reformas creyeren oportunas, atendiendo/ al estado en que se encontrase la Yglesia,/ para lo cual la encargó especialmentel hiciese la liquidacion de todas las ad-/ ministraciones que el Cabildo tenia á/ su cargo, $y$ procediese en consecuencial à lo que creyere 
conveniente al mejor/ servicio de Dios y utilidad de la Yglesia./ Se acordó asimismo se procediese à la/ distribucion de unos laudemios cobra-/dos. Y se cerró la sesion. ${ }^{288}$

Els sous, dels pocs músics clergues que han quedat, són objecte de successives disminucions, i també es redueixen el nombre de funcions. Així doncs, es produeix una primera depreciació dels salaris, el cinc de gener del 1836 ,

5. ${ }^{o}$ Desde $1^{a}$ de febrero de yd. â los 4 Sochantres, al Maestro de Capillal y al Organista se les pasaran 4 reales diarios à cada uno y dos reales a los/ Alfulleres diariamente $[\ldots]^{289}$

La segona reducció es produeix el dia set d'agost del 1837 ,

Coro:/

Al Maestro de Capilla, y los cuatro Xan-/tres á dos reales diarios cada uno/Al organista cuatro reales inclusos los/ frutos del Manso Jordi/ A los Alfulleres un real a cada uno./ A los Monacillos de Coro, treinta libras/ annuales á cada uno y los zapatos $y /$ medias/ Al Manxador se le pagara solo por entonar $y$ barrer la iglesia, y por/ lo demas se le pagará solo por lo que se le mande hacer [...]/ [fol. 8][...]/ En adelante no se hará en la Yglesia/ ni fuera de ella ningun gasto sin/ previo conocimiento y consentimiento/ del Cabildo ó de la Comision, á cuyo/ fin se dará aviso al

\footnotetext{
${ }^{288}$ Ll.R.C. $1837-1840,4$ d'agost de 1837 , fol. 6v.

${ }^{289}$ Ll.R.C. 1835-1837, 5 de gener de 1836, fol. 46.
} 
Administrador pa-/raque no pague ningun gasto $\mathrm{sin} /$ el visto bueno de la Comision. ${ }^{290}$

El tretze de març del 1838 decideixen pagar als xantres la meitat del que cobraven per cantar la Passió. I l'any 1841 se suspenen les funcions a un $\mathrm{i}$ dos cors ("coretos")

El S. Canonigo Murtra en nombre de la Comision/ presento las observaciones siguientes a fin de hacersel alguna economia posible $y$ son:/ $1^{a}$ Suspender la musica y oficios á Coros y Coretos. ${ }^{291}$

De fet, fins a la definitiva desaparició de la capella el catorze d'octubre del 1842, trobem molts exemples d'aquesta mena.

Pel que fa als salaris que hem mencionat anteriorment, i per fer-nos a la idea del que representaven en aquella època, només dir que l'any 1831 els salaris dels obrers del tèxtil, eren de set reals diaris ${ }^{292}$, que eren sumament minsos per a la subsistència. Hem de tenir en compte que el vint-i-cinc de juliol del 1835 fou incendiada a Barcelona, pels obrers, la fàbrica "El Vapor", després de la puja de preus que comença el 1833, sense anar acompanyada d'una puja de sous. Doncs bé, el mestre de capella cobrava dos reals diaris i els alfullers un real.

Pel continu davallament de sous i la incertesa de la situació, apareixen múltiples problemes i conflictes entre els músics que queden a la capella, sobretot per les

${ }^{290}$ Ll.R.C. $1837-1840,7$ d'agost de 1837 , fol. $7 \mathrm{v}$.

${ }^{291}$ Ll.R.C. 1840-1843, 28 d'octubre de 1841, fol. 16.

${ }^{292}$ TUÑÓN DE LARA, Manuel; La España del siglo XIX, Barcelona: Laia, 1978, p. 102. 
funcions ordinàries i extraordinàries. En algunes circumstàncies, fins $\mathrm{i}$ tot els músics demanen que es reformin les constitucions de la capella de música del 1735 . Per exemple, el deu d'octubre de 1834, es llegeix un memorial signat pels reverends Tomàs Riu i Miquel Fossalba (contralts), Francesc Creuet (tenor), Antoni Santamaria i Ramon Vendrell (xantres, baixos), i l'organista Pelegrí Baltasar, demanant poder assistir a funcions d'altres esglésies sense la resta de músics de la capella, per tal de cobrar un sobresou. Preveient que aquest acte aniria en contra de les constitucions, demanen que es canviïn $\mathrm{i}$ s'adeqüin a les circumstàncies de l'època.

[...] con motivo de sufrir una re-/baja de Consideracion en los ganares de Capilla de musica / de algunos años a esta parte, los exponentes conocen/la causa de esto que es la escasez de fondos de lal Yglesia y que no pudiendo por lo mismo cargar con un gasto/ de la Capilla por entero [...] acuden/ à algunos individuos aficionados de la Ciudad que estos con $/ 4^{o}$ vozes $y$ un acom-pañamiento estan haciendo aquellas funciones/ que antes hacia la Capilla y formava una gran partel de su renta. [...]/ Viendo los abajo firmados/ que dichas Iglesias acuden a estos aficionados por el escaso precio quel llevan, conocen que si ellos se dividiesen en 4 vozes y un acompaña-/miento al arbi-trio del Señor Maestro, recuperarian estas funciones/ pues que los antepondrian esos aficionados que con escandalo del/ publico estan alborotando, y retrayendo a los fieles de los templos $/ ;[. .$.

Aceptar las funciones del modo dicho, en ninguno/ de los 48 articulos de las constituciones mandadas rigurosamentel observar por V.S. e intimadas por [...] a 13 
Nbre de 1735, en ninguno del dichos Capitulos consta que se les sea prohibido en aceptarlas del modo/ dicho; pero como esto no estaba en uso, ni las circuns-/tancias no lo permitian, no nos habiamos adelantado a hacer/ un paso que se habia proyectado algunos años hace, viendo la de-/cadencia de las funciones; pero viendo que cada dia bal en aumento al disminuirse, han determinado hacer lo comunicado $[\ldots]^{293}$

Aquest memorial, però, anava seguit d'un dels clergues Ramon Bassas (flauta, fagot i oboè) i Josep Quilmetas (primer violí), en nom dels músics instrumentistes de la capella, demanant que es desestimés la petició dels cantors. El capítol donà la raó als instrumentistes, doncs dividir la capella era anar en contra de les Ordinacions de1735.

El mes de juny de l'any 1838 tornen a haver-hi problemes, doncs el mestre Barba prescindeix de dos músics de la capella per a una funció, que són l'organista Pelegrí Baltasar i el tenor Francesc Creuet. La resta d'individus de la capella es posen en contra del mestre, negant-se a assistir a un acte de la mateixa. El capítol pren mesures dràstiques, rebaixant sou i categoria a Barba, com si fos alfuller, i disol provisionalment la capella. A partir d'aquest moment Francesc Creuet s'encarregarà dels escolans de cor. ${ }^{294}$

Barba torna a ser amonestat el 1847, pel fet d'ajudar les funcions d'una companyia d'òpera que es troba a la ciutat, dirigint els assajos i fent les particel-les. Tot i que en un principi l'ajuntament havia demanat a Barba que s'encarregués dels assajos d'aquestes funcions, en sorgir

${ }^{293}$ Ll.R.C. 1833-1835, annex $\mathrm{n}^{\mathrm{o}} 106$.

294 Per a més informació d'aquest procés vegi's en el capítol III, l'apartat dedicat al mestre Josep Barba. 
greus problemes entre el mentre i el capítol, l'ajuntament pren part a favor de l'església. Finalment Barba marxarà cap a Santa Maria del Mar, a Barcelona, com a mestre de capella. ${ }^{295}$

La majoria dels músics més joves marxen de Girona, per a cercar nous objectius. Dels músics seglars que deixen la capella, a partir del 1837 , ja no en tenim més notícies, i se'n perd completament la pista. Però pel que fa als músics clergues, sí que n'anem tenint notícies a través dels llibres de resolucions capitulars. Així doncs, sabem que Onofre Bassas, marxa el 1835 cap a Lleida, com a primer violí. El contralt Tomàs Riu, marxa el 1836, i a través de les actes se sap que l'any 1843, és a l'Havana. L'organista Peregrí Baltasar, marxa el setze d'agost del 1838 , en part per tots els problemes que ha tingut amb el mestre de capella, i el vinti-tres de novembre del 1839 , tenim notícia que és a Montevideo. L'organista que vindrà després, Bernat Papell, també renuncia, el tres de març del 1842, per anar a França. I el mestre de capella Josep Barba comunica el dinou de desembre del 1850, la seva renúncia per haver obtingut plaça a Sta. Maria del Mar, com s'ha comentat a l'anterior paràgraf.

Els músics de més edat queden a la capella. Ja no es convocaran noves oposicions i els membres més antics de la capella, van morint. El canonge Francesc Juncà, insigne músic, que durant tants anys fou comissari de música de la catedral, mor el cinc de juny de l'any 1833. Mor també el xantre Antoni Santamaria, el dinou de setembre del 1842, angoixat perquè veu a venir que desapareix el cor, i que les generacions futures no coneixeran el cant litúrgic, manifestant al capítol, pocs mesos abans de morir, aquesta preocupació $^{296}$. El quatre de març de 1843, mor el viola

\footnotetext{
${ }^{295}$ Vegi's l'apartat 6.b, on es tracta tot el relacionat amb el teatre.

${ }^{296}$ Vegi's en el capítol III, l'apartat dedicat al xantre Santamaria.
} 
Feliu Busquets. Enterren a Josep Quilmetas, que durant tants anys havia estat primer violí seglar, el vuit de juny del 1844. I el xantre Ramon Virosta, mor el dia vint-i-dos de juny de l'any 1847 .

Molts d'aquests músics, encara veieren com quedà suprimida la capella de música de la catedral de Girona, i moltes altres capelles, l'any 1842. Per ordre del ministre d'hisenda, segons el regent del regne, aquell any s'aproven els pressupostos del culte de totes i cada una de les catedrals, segons el que ells anomenen "unas bases generales y comunes a los Yntendentes de las respectivas provincias". A la catedral gironina li adjudiquen un pressupost de 48.000 reals. Aquestes bases generals, constaven d'uns punts, el primer dels quals és $1^{a}$ Suprimir los gastos que no sean precisos, especialmente los que ocasionan las Capillas de Música. ${ }^{297}$

Atesa la seva importància, s'ha transcrit la carta del govern eclesiàstic del Bisbat de Girona, doncs es tracta del document mitjançant el qual queda suprimida la capella de música, l'any 1842, per decret; vegi's l'apèndix documental d'aquest capítol.

Més envant, també es detalla com el capítol emprà aquests 48.000 reals. I es pot observar que del que havia estat una capella de vint-i-cinc músics, no en queda gairebé res, únicament dos escolans de cor, un salmista (enlloc dels xantres), l'organista, l'orguener i el manxador.

${ }^{297}$ Ll.C.R. 1840-1843, annex 128. Vegi's en l'apèndix documental, el $\mathrm{n}^{\circ} 4$, Supressió oficial de les capelles de música del 20 d'octubre de 1842 . 


\section{RECURSOS INSTRUMENTALS I MATERIALS DE LA CAPELLA}

A la Seu, durant la primera meitat del segle XIX, hi havia diversos instruments que eren utilitzats tant en les funcions ordinàries com extraordinàries. Aquests instruments, dels quals el capítol n'era propietari, eren un contrabaix, dos tibles, una tenora, un sacabutx, dues trompes i un manacord, a més dels orgues. A la capella, hi havia instrumentistes de violí, viola, flauta, fagot i oboè, però cada un d'aquests instrumentistes era propietari dels seus instruments.

És a través de les fonts consultades que coneixem l'existència d'aquests instruments. Alguns d'ells encara es conserven, tot i que la majoria d'ells han anat desapareixent en el transcurs del temps. Trobo interessant de fer una ressenya dels instruments que han anat apareixent en la documentació, doncs la música que es composava i s'interpretava a la seu estava directament condicionada per l'existència i el bon estat dels mateixos.

\section{L'ORGUE GRAN}

En aquest apartat serem testimonis d'un dels canvis més importants que es produïren en la història de l'orgue gran de la seu. Durant el període d'anys que ens ocupa es desmantella l'orgue gran, antiquíssim, barroc, ubicat en un lateral i elevat, com la majoria d'orgues catalans; i construeixen un nou orgue, aprofitant tot el que poden de l'antic, situant-lo al centre de la nau de la catedral. A aquest instrument, li afegeixen nous registres segons els gustos de l'època $i$ el recobreixen amb una gran caixa. No podem jutjar els qui prengueren la decisió de realitzar 
canvis tan radicals en la forma i l'estructura de l'orgue, ja que aquesta decisió fou llargament meditada, contrastada i debatuda, fins a ésser consensuada; els membres d'aquella comunitat feren el que varen creure millor per a l'orgue i les necessitats musicals que tenien en aquell moment.

Aquest orgue, com el de l'església de Sant Feliu i molts d'altres, fou totalment destruït durant la Guerra Civil del 1936-39.

Les properes planes estan estructurades en dues parts. En la primera part he posat les característiques que ens permetin fer una idea de com era l'orgue l'any 1800. Malauradament, la informació trobada no és massa extensa, i tampoc fa referència a aspectes que m'hauria agradat saber, com ara el nombre i el tipus de registres de l' antic orgue. En la segona part, faig un estudi cronològic de les diferents afinacions, reparacions i modificacions que s'anaren realitzant en l'orgue, des del 1800 fins al 1850, per tal de poder veure l'evolució i els canvis que es feren en l'instrument.

\section{a) Característiques}

L'orgue gran de la catedral estava elevat, situat al costat de l'evangeli. Davant de l'orgue gran hi havia l'orgue petit, també elevat, anomenat de semidobles; aquest estava collocat al costat de l'epístola, com era costum en la tradició musical barroca. ${ }^{298}$

Hi ha diversos documents que corroboren aquestes dades. D'una banda, segons l'acta capitular del divuit de

\footnotetext{
298 Pot ser útil veure la planta de la catedral gironina; es troba en l'apèndix de làmines, al final del vol. IV, indicada com a $\mathrm{n}^{\mathrm{o}} 1$.
} 
maig de 1805, sabem que els escolans dormien damunt la sacristia.

Itt: El S. ${ }^{\text {or }}$ Torra hizo la proposicion siguiente[...] En atencion à que corren algunos ladrones/si V.S. lo tiene à bien se compondran unas Cam-/panetas sobre la puerta de la Sacristia, que no pu-/diese ser forzada ô avierta sin hacer algun ruido/ y como los Escolanes duermen encima, no podrial abrirse sin que se sintiese $[\ldots]^{299}$

D'altra banda, per resolució de dotze de juny de l'any 1809 , referent a un dels bombardejos de l'exèrcit francès, sabem que els canonges s'amagaren a les cambres dels escolans, que estaven situades pujant les escales de l'orgue gran, damunt de la sacristia, que està situada al costat esquerra de la nau, entrant per la porta principal.

Nota: En el dia 14 de este mes, dadas las doce de la noche em-/pezaron los Franceses el Bombardeo contra esta/ Ciudad con un furor que dificilmente se puede expli-/car. Los vecinos, que pudieron, se refugiaron â esta/ Sta. Iglesia, acomodandose en sus Capillas, Claustros,/ Torre, Sacristias, y demas lugares â prueba de bom-/ba. Los Canon. ${ }^{s}$ ocuparon los quartos de los Escola-/nes, que estan, subiendo la escalera del Organo/mayor, y caen sobre las Sacristias; bien $q .{ }^{e}$ lal mucha gente, que concurrio â este lugar, los tu-/bo sumamente incomodados; pero era necesario sufrir-/lo todo por el bien de los vecinos. ${ }^{300}$

\footnotetext{
${ }^{299}$ Ll.R.C. 1803-1807, 18 de maig de 1805, fol. 190v.

${ }^{300}$ Ll.R.C. 1803-1807, 12 de juny de 1809 , fol. $193 \mathrm{v}$.
} 
També és interessant el document que apareix en la Consueta de l'organista escrita per Antoni Guiu, que explica el recorregut per dins la seu de la processó del tercer diumenge. Segons aquest manuscrit, el Santíssim sortia del cor, passava primer davant la capella de l'Anunciació, després per sota l'orgue petit, a continuació per davant la capella dels Dolors, seguidament passava per sota l'orgue gran i acabava a la porta d'entrada, on s'incensava.

Modo de tocar la Profesó del tercer Diumenge 1...Quant lo Presta pren lo $S{ }^{m}$ Comensa tocar lo/ primer vers per B.fa mi b.moll i acaba, quant lo $S .^{m}$ ix del Cor, y fina per Bfami./

2...Acabat los Ministrils fins que lo $S^{m}$ es devant la Capella de la Anunciata i fina per ffaut./

3...Acabat la Musica, fins que lo $S^{m}{ }^{m}$ és sotal la Orga Petita y fina à B. fa mi./

4...Acabat los Ministrils, fins que lo $S .^{m}$ és deIvant la Capella dels Dolors, y fina per ffaut./

5.. Acabat la Musica, fins que lo $S .^{m}$ és sotal la Orga Gran, ab los flautats y fina per Bfami./ 6...Acabat los Ministrils, fins que lo $S .^{m}$ és devant/ la porta gran que incensan, y fina per ffaut./

Acabat las respostas del V Panem de ce-/lo, y Amen, se toca And. ${ }^{\text {te }}$ fins que la Mu-/sica comensa. Tantum Ergo que lo/ Org. ${ }^{a}$ deu acompañar. ${ }^{301}$

En el següent document, datat el 1818, és interessant observar com els canonges es refereixen a la ubicació de l'orgue petit o de semidobles, dient que estava

${ }^{301}$ ACCG : GUIU ROQUER, Antoni. Consueta de l'organista...p.65 (la numeració és meva). 
orisontalmente paralelo al grande, i col-locat al costat de l'epístola.

$$
Y^{m} \text { : El S. }{ }^{\text {or }} \text { Can. }{ }^{\text {go }} \text { D. }{ }^{n} \text { Pedro Pons propuso: }
$$
M.Y. ${ }^{l e} S^{o r}$ : Parece, que serial mucho mas decente, y conforme, que en los oficios cantados con el Organo y Canto-/ res de la Capilla de Musica, que vulgarmente se llaman de Corets, los Can-/tores que cantan en el pulpito, lo verifiquen en el Or-/gano pequeño, q. ${ }^{e}$ se halla orisontalmente paralelo al grande, como se practica regularm. ${ }^{\text {te }}$ en todas las Catedrales, y segun tengo entendido lo practicaban tambien/ en esta antiguam. ${ }^{\text {te }} y$ dejo de hacerse porque el pavimento de dho./ organo pequeño no estaba muy seguro. Por lo q. ${ }^{e}$ podria V.S. mandar/ q. ${ }^{e}$ se reconozca y se asegure, $y q{ }^{e}{ }^{e}$ se restablezca el uso antiguo/ en esta parte para evitar esta deformidad, y el inconvenientel de $q .{ }^{e}$ el Can. ${ }^{g o}$ $q .^{e}$ canta la Epistola en dichos Oficios, tenga quel esperarse muchas veces al pie del pulpito hasta q. ${ }^{e}$ hayan baxado/ de el los Cantores, y tenga $q .{ }^{e}$ penetrar por medio de ellos./

$R .^{n}$ Que se reconozca y asegure el pavimento del Or-Igano pequeño al efecto de que los Musicos que can-/tan en el pulpito de las Epistolas canten/ en dho Organo quando esté habilitado. ${ }^{302}$

La darrera informació que citaré referent a la ubicació de l'orgue gran és extreta del 1libret "La catedral de Girona" escrit pel canonge Josep Calzada i Oliveras. Aquest comenta que l'orgue petit està situat a la paret meridional, que és on hi ha la porta dels Apòstols; per tant

${ }^{302}$ Ll.R.C. 1817-1819, 4 d'abril de 1818, fol. 69. 
estaria al costat de l'epístola, i confirmaria les dades aportades pels documents anteriorment citats.

"Además del organo mayor, consta en Acta la construcción del organo menor, el cual se ajustó a la pared meridional de la Iglesia y al pequeño coro que hay en la Capilla de San Juan ${ }^{303}$, o sea, en la actual Capilla de Sta. Elena" 304

L'instrument del segle XIX, encara conservava fustes $\mathrm{i}$ maquinària $\mathrm{amb}$ tres-cents anys d'antiguitat, segons l'afirmació d' Honorat Grinda, orguener, el cinc de maig del 1826.

Lo abaix firmát habent fet lo regoneixement del Orgal gran de esta Sta Ygla, dich que es antiquisima la sua/ construcció; y segóns lo mal estát en que se troban las Fustas/ de la sua maquina manifesta ser obra de tres cents anys/ $[\ldots]^{305}$

\section{b) Diferents reconstruccions}

En l'acta capitular del dos de febrer de l'any 1808 , l'organista informava al capítol que les manxes estaven molt malmeses i que s'haurien de fer noves, per tal que amb menys esforç es poguessin utilitzar. No tinc notícia de que es realitzés res, doncs aquest any sobrevingué a la ciutat la invasió francesa.

\footnotetext{
${ }^{303}$ Quan el mestre Civil, en el seu llibre El fet musical..., Ob.cit., parla de l'orgue de la catedral, també anomena aquestes capelles, però actualment els noms de les capelles han canviat. Cal dir que el canonge Calzada, al parlar de l'orgue es remet als estudis de F. Civil.

304 CALZADA OLIVERAS, Josep. Catedral de Girona. Barcelona: Escudo de Oro, 1995. p.82.

${ }^{305}$ Ll.R.C. 1825-1827, 5 de maig de 1826 , annex $\mathrm{n}^{\circ} 59$.
} 
L'any 1810, com a conseqüència dels setges, l'orgue quedà greument malmès, sobretot les manxes, però el capítol no disposava de prou fons per a "obres majors", i era més urgent arreglar la volta del teulat. Sortosament, l'orgue no havia desaparegut, com passà amb molts altres orgues de la ciutat.

Res. Que se haga este reconocimiento, y los fuelles, si sel pueden hacer con un gasto modico, a causa de que el/ Cabildo no se halla con caudales para emprender obras/ mayores, $y$ lo q. ${ }^{e}$ ahora urge mas es el tejado de la Bobeda, pa-/ra que esta se pueda conservar, y con las aguas quel recibe no se desmorone. ${ }^{306}$

Les manxes no s'arreglaven, i el catorze d'octubre l'organista Antoni Guiu presentà un memorial exposant que a més de manxes, també calien registres i altres peces per a que es pogués utilitzar l'orgue gran, suggerint que es podrien aprofitar les peces de l'orgue de Sant Domènec i les d'altres que "existien" a la ciutat. Aquesta afirmació ens dóna a entendre que amb els setges havien quedat malmesos més d'un orgue.

El S. ${ }^{\text {or }}$ Presid. ${ }^{\text {te }}$ leyo un Memor. ${ }^{l}$ presentado por el Organ. ${ }^{\text {ta }} /$ de esta S. Igl. ${ }^{a}$ al Govierno q. ${ }^{e}$ le à dicho se solicitase/ lo necesario para componer el Organo Grande exponien-/do que necesitaban fuelles, algunos registros, y otras co-/sas por haber quedado maltratado de resultas de las/Bombas; y que del Organo de S. Domingo y otros de los/ que existian en esta Ciudad se aplicasen algunas co-/sas al de la

${ }^{306}$ Ll.R.C. $1807-1812,28$ de juliol de 1810 , fol. $24 \mathrm{v}$. 
Iglesia, para . $^{e}$ se pudiese usar, y fuesen/ las funciones con la solemnidad $q .^{e}$ corresponde: Al/ pie de este Memor. ${ }^{l}$ estaban dos decretos del Adminis-/trador de bienes Nacionales $y$ Comisar. ${ }^{o s}$ previnien-/do que el Memorial de presentarse en nombre del $S^{\text {or/ }}$ / Obispo $y$ Cabildo, y à este fin se dirigió oficio al/ Illmo. que leyo dcho. S. ${ }^{\text {or }}$ Presid. ${ }^{\text {te }}$ juntam. ${ }^{\text {te }}$ con los/ demas papeles: sobre lo qual acordara el Cab. ${ }^{\circ}$ lo concernientel

Res. ${ }^{n}$ Que el $S .^{\text {or }}$ Valparis como Obrero y el $S .{ }^{\text {or }}$ Ma-/tute se encarguen de formar este recurso. $[\ldots]^{307}$

Per fi, l'any 1812 s'arreglaren les manxes, i l'encarregat de fer-ho fou en Francesc Vilella, l'orguener del capítol. Entre altres coses interessants digué que l'orgue tenia cinc manxes i que havia deixat a punt de funcionar l'orgue gran i la cadireta, a més de moltes flautes que "de anys no parlaban". La recomposició pujà dues-centes lliures, tres sous i nou diners.

Compte dels Jornals ordinaris, extraordinaris, y/ materials empleats per mi en la recomposició del Orga/ gran de la Cathedral de la present Ciutat./

Primo: per 80 Jornals ordinaris $i$ extraordinaris fora del la dita Cath. ${ }^{l}$ per la recomposicio del Orga gran, â rahó de $1 \mathrm{ll} 17 \mathrm{~s}$ $6 d$ per Jornal...161 $115 \mathrm{~s} /$

Mes: per las ludas [sic] que tinch gastát en las sinch manxas, secrets, / porta=véns, y canóns de las manxas... $18 \mathrm{ll} \_$s/

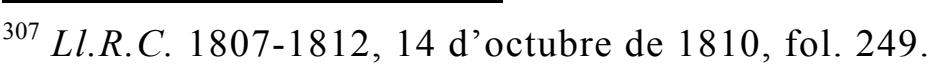


Mes: per claus, petits, y grans, empleáts en las manxas, interior,/ $y$ exterior del sobre dit orga... $6 \mathrm{ll}{ }_{-} s /$

Per AyguaCuit, y Guix ... 6 ll 5 s/

Per filferro, y de llautó ... 5 ll $10 \mathrm{~s} /$

Per estany, fustas, y verguillas del teclat $3 l l 3 s 9 d /$

total suma $200 \mathrm{ll} 3 \mathrm{~s} 9 \mathrm{~d} /$

Ab la dita recomposició no sols queda corrént lo Orga gran, y/ cadireta, si que també, entonadas varias flautas que del anys no parlaban; com podrá informar lo Organista del la present Igla./ Gerona 25 Mars de 1812/ Francesch Vilella Organer. ${ }^{308}$

És a partir de les resolucions capitulars de l'any 1815 , que ens adonem del gran pes que tenia el canonge Francesc Juncà; tant pel que feia a l'orgue, com en qualsevol fet de transcendència musical, el seu consell era sempre imprescindible.

Itt: El mismo $S .^{\text {or }}$ Valparis en calidad de Obrero Supli-/co al Cabildo que nombrase uno de los SS. Canonigos/ que tengan inteligencia, para dirigir, reconocer, y deter-/minar lo mas util sobre las Obras, que ne-/cesitan para poner corriente el Organol mayor de la Yglesia./

Res. ${ }^{n}$ Que juntam. ${ }^{\text {te }}$ con los SS. Obreros Mayor $y /$ menor concurra el $S{ }^{\text {or }}$ Junca. ${ }^{309}$

Referint-nos a l'orgue gran, l'any 1826 es produeix l'arranjament $i$, en definitiva, el canvi més important de tota

\footnotetext{
${ }^{308}$ Ll.C.O. 1813-1815, mig fol. Solt, blau cel, vertical, inscripció "1812".

${ }^{309}$ Ll.R.C. 1812-1815, 4 de març de 1815, fol. 135.
} 
l'època estudiada. Com que tot el procés m'ha semblat força interessant, he transccrit les decisions més rellevants que s'anaren prenent al respecte.

Tot començà amb l'informe que, el vint-i-cinc de febrer de l'any 1826, l'organista Antoni Guiu, feu al capítol. En aquest informe explicava que l'orgue estava molt deteriorat i que necessitava urgentment una reparació.

Se leyo una proposicion de los S.S. Com. ${ }^{s}$ Obreros, relativa a que, / habiendoles manifestado el organista de esta St. ${ }^{a} \mathrm{Ygl}^{a}{ }^{a}$, que el orga-/no estaba en muy mal estado, y a peligro de inutilizarse, si no/ se atendia a su composicion, habian hecho reconocerlo por el/ organero de Cabildo, quien manifesto, que la composicion/ era de consideracion, y que por lo mismo pudiera llamarse/ a otro facultativo para formar el presupuesto de gastos./ En su vista, teniendo noticia dichos SS. $q .{ }^{e}$ en Perpinyan hay/ un facultativo acreditado, propusieron $q .{ }^{e}$ podria llamar/ se le abonando los gastos de su viaje, y demas./ Res. ${ }^{\text {on }}$ Como lo proponen los S.S. Obreros. ${ }^{310}$

${ }^{310}$ Ll.R.C. $1825-1827,25$ de febrer de 1826, fol. $28 \mathrm{v}$. 
El capítol avisà els dos germans orgueners de Perpinyà, Honorat i Antoni Grinda, per a que fessin un pressupost. Aquests organers havien construït els orgues de l'Escarene, l'any $1791^{311}$ i de Villefranche-sur-mer ${ }^{312}$, a prop de Niça.

Segons aquests orgueners, l'obra havia de costar quatre mil lliures catalanes, de les quals les primeres dues mil es pagarien a mesura que s'anés realitzant l'obra, i les restants quan aquesta hagués finalitzat. És de remarcar l'interès que el capítol tenia en posar un registre de veus humanes, tan de moda en els orgues francesos del primer romanticisme.

El Señor Hurtado como Obrero dijo: que habiendo llegado el orga-/nero de Perpinyan; y reconocido el Organo, presentaba su informe re-/ducido á que para la completa composicion del Organo Mayor se nece-/sitarian $4000 \mathrm{ll}$. Catalanas, y opinaban los Obreros despues de infor-/mados del Organista que reconociendose abilidad en este organero/ se podia tratar la contrata de composicion con el, para que la efec-/tuase./

Res. ${ }^{\text {on }}$ Que los Canonigos obreros juntam. ${ }^{\text {te }}$ con el señor Junca, y el orga-/nista, hagan desde luego esta contrata, con las ventajas que puedan:/ que por dicha cantidad se obligue el organero a poner un registrol de voces humanas: y que se le den las $4000 \mathrm{ll}$. en varios plazos, el/ ultimo de los quales será de 2000.

\footnotetext{
${ }^{311}$ CABOURDIN, Yves., "La restauration de l'orgue de L'Escarene (Grinda 1791)", Facteurs d'orgues français, VIII (1984), ps. 40-42.

${ }^{312}$ GIROUD, Michel., "La restauration de l'orgue Grinda de l'église Saint-Michel de Villefranche-sur-mer", Facteurs d'orgues français, (1982), ps.20-23.
} 
las que no se entregarán hasta/ estar concluida la obra à satisfaccion, y aprobacion de peritos q. ${ }^{e}$ se hará por parte del Cabildo. ${ }^{313}$

Tot seguit presento un resum amb el més interessant de les setze disposicions que tenia aquest pressupost:

1- Desmuntar, netejar i acordar tot l'orgue gran; i posar a punt l'orgue petit, per a poder-lo utilitzar mentre s'arregla el gran.

2- $\quad$ Fer nous els secrets de l'orgue gran, cadireta, ecos i contres. De forma que l'orgue gran i la cadireta tinguin cinquanta-quatre tecles movibles, els ecos tres octaves (augmentant en deu tecles els anteriors) i les contres una octava i mitja. A més, els secrets hauran de ser més amples i més grans per tenir la capacitat d'afegir-hi, sempre que es vulgui, nous registres.

3- Es farà de nou tot el mecanisme: els tres teclats mòbils, seran d'os; i també es farà el pedaler.

4- Queda a càrrec de l'orguener, posar els tubs nous que faltin com a conseqüència d'augmentar el nombre de registres.

5- Es construirà un registre nou de veus humanes en l'orgue gran, i un altre de bordó a la cadireta, per tal que l'harmonia d'aquesta guardi proporció amb l'orgue gran.

6- Les manxes es faran noves, per a donar a l'orgue el vent que necessita, sense un esforç excessiu.

7- $\quad$ Tots els registres i tubs inutilitzables es faran de nou.

9- Les fustes i tot material que es trobi en bon estat podrà ser reutilitzat.

10- Tot el mecanisme es construirà segons les regles de l'art, utilitzant bons materials tant de fusta com de metall.

${ }^{313}$ Ll.R.C. $1825-1827,5$ de maig de 1826 , fol. $34 \mathrm{v}$. 
La transcripció íntegra dels documents originals la podem veure en l'apèndixs documental. En el document 6 hi ha la transcripció de 1'Informe reducido, citat en la Resolució capitular del cinc de maig de l'any 1826; tot i que el títol és castellà, el manuscrit està escrit en català, fet que demostra la utilització del català com a llengua vehicular en la Catalunya Nord. En el document 7 hi podem veure la transcripció del Pressupost de restauració complet, amb les seves setze disposicions, escrit en castellà.

Els diners per a la reforma de l'orgue sortiren de l'obra de la catedral, de la pabordia de Lloret i també de les aportacions particulars dels canonges Francesc Juncà, comissari de música i antic mestre de capella de Girona i Toledo, i del canonge Dagas.

El Canonigo Codorniu propuso que se podian tomar las 4000 ll./ à Censal de una cuenta de la Obra, para la composicion del Organo; 2000 ll./ de la Pabordia de Lloret, 1000 del Canonigo Dagas, y 366. ll, $13 \mathrm{s.} / \mathrm{y} 4$ dineros del Canonigo Junca, cuyas dos ultimas partidas quedarán/ para Misas, despues de muertos los expresados S.S. Canonigos Da-/gas y Junca, y sus actuales respectibas criadas [...]/ señalandose por estipendio de cada Misa unal libra catalana por las de Junca, y dos pesetas por idem por las/ de Dagas [...]/

Res. ${ }^{o n}$ Que se tomen à Censal las 4000 ll para dcho. fin $[\ldots]^{314}$

Les obres s'iniciaren definitivament el vint-i-dos de desembre del 1826, començant-se d'aquesta manera la transformació de l'orgue barroc. Tot sembla transcórrer

${ }^{314}$ Ll.R.C. $1825-1827,5$ de maig de 1826 , fol. 34 v i 35. 
sense entrebancs fins que el quinze de juny del 1827, a la sala capitular esclatà una gran polèmica, sobre on posar definitivament l'orgue.

Es contemplaren dues opcions que eren deixar l'orgue elevat, tal com estava o posar-lo al mig de la nau, darrera del cor, tal com està avui dia.

Les opinions es dividiren entre les dues opcions. És per això que els canonges decidiren formar una comissió d'estudi. Entre els partidaris de posar l'orgue al centre de la nau hi havia el canonge Juncà, l'organista Antoni Guiu, el mestre de capella Josep Barba i l'orguener Francesc Vilella; aquest últim deia haver consultat aquest afer amb diversos "mestres artistes" constructors d'orgues i que també consideraven aquesta opció com la més idònia.

Fou decisiu, en el moment de les votacions, l'argument del canonge Juncà, dient que el nou emplaçament de l'orgue seria millor per a la música i per a la capella, doncs al no haver-hi tanta distància entre l'orgue i el cor la sonoritat de la música quedaria més reunida $\mathrm{i}$ l'organista podria adonar-se immediatament dels instrumentistes absents, podent-los suplir amb el seu instrument. Pot llegir-se la transcripció de l'acta capitular, datada el quinze de juny de 1827, vegi's en l'apèndix de documents el 8: Acta del canvi de lloc de l'orgue.

Les obres anaven endavant $\mathrm{i}$ el dia tretze de juliol es feien les parets per a col-locar-hi l'orgue.

El S. Presidente dijo: que con motivo de hacerse las/ paredes $p .^{a}$ la colocacion del Organo mayor, podrian decirsel las horas Canonicas, y Oficios en la Capilla de la Esperanza $[\ldots] /$ 


$$
\text { Res. }{ }^{\text {on }} \text { Placet. }{ }^{315}
$$

L'obra per fi s'acabava, i decidiren buscar un revisor, algú aliè a les reparacions per a que donés el vist-i-plau de les obres.

La Comision de Organo propuso que estando ya al finalizarse la Obra del/ Organo podrían nombrarse revisores./

Res. ${ }^{\text {on }}$ Propongan los Comisarios el sugeto que mejor parezca. ${ }^{316}$

Aquest seria en Mateu Ferrer, anomenat popularment Mateuet, organista de la catedral de Barcelona, que en aquell temps estava considerat el mejor professor de la província de Catalunya ${ }^{317}$. Emeté la seva opinió sobre l'orgue per escrit, el dotze de març de l'any 1830, i fou llegida en la sala capitular el dia catorze de març. A continuació oferim un resum dels punts més importants d'aquesta carta, document molt interessant per la gran informació que ens aporta.

Entre altres coses deia que l'orguener havia fet l'obra tal com va quedar acordat en el pressupost. Que el so de tots els registres de l'orgue era bo i sonor, i si semblava flac era per la gran nau de la catedral, que escampava l'eco pels quatre costats. La circumstància anterior es podria solucionar, en gran part, "tapant" les tres cares del cor, i els laterals (és a dir, fent una caixa de ressonància). El fet de "tapar" l'orgue, comportaria bastants avantatges : preservarlo de l'aire i la pols, conservar-ne millor l'afinació i

\footnotetext{
${ }^{315}$ Ll.R.C. 1827-1829, 13 de juliol de 1827, fol.9.

${ }^{316}$ Ll.R.C. $1829-1831,28$ de febrer de 1830, fol. 20.

${ }^{317}$ Ll.R.C. 1829-1831, 12 de març de 1830 , fol. $20 \mathrm{v}$.
} 
augmentar-ne la sonoritat. Aniria bé, també, fer unes obertures que mitjançant un mecanisme s'obrissin i es tanquessin per a poder fer matisos de forte i piano, és a dir, l' expressió. El registre de veus humanes era bo i estava ben construït; si no sonava prou fort, era perquè li faltava la caixa de ressonància. El constructor havia posat catorze registres nous, no mencionats en el pressupost, que estaven ben construïts $\mathrm{i}$ tenien bon to, pel que valia la pena de quedar-se'ls. La col-locació i distribució del mecanisme estaven fetes amb gran encert, ja que es podia, amb un cop d'ull, veure'l tot.

Considerant la gran importància d'aquesta carta d'en Mateu Ferrer, la transcric de manera completa, en l'apèndix és el document 9: Carta de'n Mateu Ferrer, del 24 de març de 1830 .

Després d'haver llegit aquest informe, els canonges del capítol acordaren que valia la pena comprar els catorze registres nous, i construir la caixa de ressonància.

Així doncs, és a partir d'aquest moment que tenim l'orgue al centre de la nau recobert amb un moble de fusta per a la millor ressonància. Durant la Guerra Civil de 193639 aquest orgue quedà totalment destruït, i el van haver de tornar a construir. Però l'orgue que ens ha arribat als nostres dies, encara conserva la mateixa ubicació que els membres de la catedral decidiren l'any 1830 .

El capítol no disposava de fons per a pagar els catorze registres de més que l'orguener havia posat a l'orgue. I el que feren fou entregar l'orgue petit, en concepte de pagament, a l'orguener Grinda. Així, en les actes del tres de juliol de 1830, els canonges acorden l'entrega de l'orguenet, especificant que, sobretot, no es realitzi en hores de residència. Suposem que es féu 
d'aquesta manera per evitar les protestes dels músics beneficiats de la capella.

\section{Cabildo extraord. ${ }^{\circ} /$}

El S. ${ }^{r}$ Canonigo Toronell hizo prte., $q .{ }^{e}$ en virtud de la contrata otorgada con el/ Organero Grinda debia entregarsele el organo pequeño; pero $q .^{e}$ el no querial verificarlo sin obtener antes el permiso del Cab. ${ }^{\circ}$

$R .^{n}$ Entreguese el mencionado organo à dcho. Grinda, procurando sacarlo en ho-/ras en $q .^{e}$ no haia residencia. ${ }^{318}$

No és fins al dia dotze de maig de l'any 1840 que tornem a trobar notícies de l'orgue. Aquest dia l'organista presentà un informe al capítol sol-licitant d'arreglar urgentment l'instrument, doncs estava molt desafinat $\mathrm{i}$ alguns registres no funcionaven. No hem pogut trobar aquest informe, però l'acta capitular que en fa ressò deia el següent.

El S. ${ }^{r}$ Can. ${ }^{g o}$ Compta como Obrero hizo presente $q .{ }^{e}$ el/ Organista de esta Yglesia le habia presentado un estado de las/ obras ó repaso $q .{ }^{e}$ tiene de hacerse en el Organo de la Yglesial por hallarse muy desafinado, y con algunos registros descompuestos./

Res. ${ }^{o n}$ Que los dos SS. Cangos Obreros se abisten con el $S .^{r}$ Calleja, y le ha-/ gan presente q. $^{e}$ no hallandose la Obra de la Yglesia con fondos/ para costear los gastos de la comp.on del Organo q. ${ }^{e}$ el Cabildo/ espera lo hara presente a la Junta Diocesana y vea si

${ }^{318}$ Ll.R.C. 1829-1831, 3 de juliol de 1831, fol. 33. 
pue-/de conseguir se libre alguna cantidad a la Obra p. ${ }^{a}$ dho fin. ${ }^{319}$

[...] dcho Compta hizo presente $q .^{e}$ en vista de lo acorda-/do p.r V.S. en el Cabildo anterior se abistó con el $S^{r}$ Callejá como/ individuo de la Junta Diocesana al q. ${ }^{e}$ le habia hecho presente el/ estado en $q .{ }^{e}$ se hallaba el Organo de esta Yglesia y $q .{ }^{e}$ si la Junta no da-/ba alguna cantidad $p^{a}{ }^{a}$ la composicion de dcho Organo [...], sucederá de si se dilata/ el componerle se hechará a perder mas, y será mas costoso, el $q .{ }^{e}$ ma-/nifestó q. ${ }^{e}$ la Junta en el dia tampoco se halla con fondos $p .{ }^{a} /$ costear dicho gasto mas

$q .^{e}$ lo haria presente a la Junta, y esperabal se satisfarian sus deseos tan pronto como ingresase cantidad alguna./

Res. $^{\text {on }}$ Queda enterado el Cabildo. ${ }^{320}$

Tot i que només havien passat deu anys des de l'última reparació, les circumstànies polítiques i socials havien canviat moltíssim. En els anys quaranta, s'havien ja produït les grans desamortitzacions, i l'Església estava pràcticament sense fons econòmics. Com es pot veure, en l'acta capitular anterior, ni el capítol, ni la Junta Diocesana disposaven de prou diners per a poder afrontar la reparació. Es donaren moltes voltes a l'assumpte $\mathrm{i}$ avisaren un orguener de Barcelona per a que fes un pressupost, però no pogueren dur a terme l'arranjament de l'orgue. Durant els anys successius el capítol s'haurà de fer enrera davant més d'un projecte, no per manca de voluntat, sino per falta de recursos econòmics.

\footnotetext{
${ }^{319}$ Ll.R.C. $1837-1840,12$ de maig de 1840 , fol.52v.

${ }^{320}$ Ll.R.C. 1837-1840, 20 de maig de 1840, fol.53.
} 
El S. Cango Murtra hizo presente tenia noticia de Barna/ que el organero vendria y queria se le pagase el viajel el que no podia hacer tasa de los gastos del Organo hasta $q .{ }^{e}$ lo/ viera. $[\ldots]^{321}$

Ens trobem a l'any 1845 i fa cinc anys des de que es va parlar per darrera vegada de l'orgue i la reparació ja no pot esperar més. En aquest moment, decideixen avisar un orguener de Mallorca que es troba a Barcelona; es tracta d'Antoni Portell, del qual els capitulars en tenen bones referències, doncs es diu que ha restaurat l'orgue de Vic amb gran encert.

El S.r Cango Compta hizo presente $q .^{e}$ habial hablado con una dignidad de Vich y le dijo ha/bian compuesto el organo de aquella Catedral/ por un organero de Mallorca el $q^{e}$ en la actualidad esta en Barna lo/ $q .{ }^{e}$ hace presente a VS por si gusta valerse de el p. ${ }^{a}$ compo-/ner el de esta Yglesia./

Res. ${ }^{n}$ Se comisionan al S. Compta y los dos SS Obre-/ros p. ${ }^{a} q .{ }^{e}$ escriban a Barcelona y saber del dicho Organero $p .^{a} q^{e}$ venga si puede $p .{ }^{a} /$ tratar sobre la comp. ${ }^{\text {on }}$ del Organo de es-/ta Yglesia al q. ${ }^{e}$ se le abonará los gastos de/ viage á esta. ${ }^{322}$

El Can. ${ }^{g o}$ Sr. $^{\text {io }}$ dijo habia tenido abiso del/ Organero en $q^{e}$ le dicen habia salido p. $^{a}$ Sevilla/ mas $q .{ }^{e}$ pronto regresaria y asi $q .^{e}$ se le escriba/ dandole noticia de lo q. ${ }^{e}$ tiene de hacer en dho/ Organo y de cuantas octabas es./

${ }^{321}$ Ll.R.C. $1840-1843,25$ de juny de 1840 , fol. 2.

${ }^{322}$ Ll.R.C. 1843-1846, 6 de juny de 1845, fol. 25. 
Res. ${ }^{\text {on }}$ Que el Organista forme una nota de lo $q .{ }^{e}$ se/ tiene de hacer y se le remita. ${ }^{323}$

Finalment l'Antoni Portell arriba de Sevilla i elabora un pressupost amb el que s'hauria de fer. La carta del pressupost l'he transcrita a continuació i també l'he reproduïda per a que podem veure els interessants dibuixos que l'acompanyen. Vegi's pel cas en l'apèndix de làmines al final del IV volum, la $\mathrm{n}^{\mathrm{o}} 2$, consistents en una trompetria de batalla, tipica dels orgues hispànics.

Relacion de lo que indispensable necesita el Organo de la Cathedral de la Ciudad/ de Gerona para quedar en toda perfeccion $y$ producir el hafecto que requierel un Organo es lo siguente los dos registros nuevos del Organo Mayor y Cadiretal y ponerlos en su correspondiente situacion la Cadireta detras del Organista $1^{\circ}$ tecglado/Organo principal $2^{\circ}$ tecglado mas tres registros de trompeteria nuevos en estal figura y el fuelle nuevo sin haser el mas minimo ruido y dar el viento/ al mismo grado de igualdad de manera que no poner el Organo de este modo nuncal puede hirbien recomponiendolo aci como sencuentra por dinero que segasta nunca sera/ Organo, y el justo precio de lo esperado es el de dos mil y quinientos duros/ moneda española............Son \#2.500 duros/

hotra Cuenta para limpiar y hafinarlo / 250 duros/ respondiendo/ yo de huno y hotro hatada perfecion/ Antonio Portell y Fuyana Organero./ [v]

${ }^{323}$ Ll.R.C. 1843-1846, 11 de juliol de 1845, fol. 26. 
D. ${ }^{n} \quad$ Antonio Portell y Fuyana Organero/ Suservidor vive en la Isla de Mallorca/ Calle de la Barrateria $N^{o} 11$ frentel las Miñonas en Palma. ${ }^{324}$

Amb el pressupost a la mà, el capítol demana parer a dues persones: a l'organista de la Seu, Antoni Xandiera i al també organista Joan Carreras, que en aquells moments començava a realitzar funcions de mestre de capella pels múltiples problemes del capítol amb el mestre Barba.

Muy Ill. ${ }^{e} \quad$ Cabildo: los bajo firmados no teniendo bastantes conocimientos/ ni esperiencia en lo que se les pide, serian de parecer que este mis-/mo plan que presenta el $S^{r} \quad{ }^{r} .^{n}$ Antonio Portell Organero quel se remitiera al $S .{ }^{r} D{ }^{n}$ Mateo Ferrer Organista de la Cate-/dral de Barna quien ha Concurrido muchas veces en seme-/jantes en diferentes comisiones de esta especie; y â mas quel el tal $S^{r}$ tendrá presente de cuando vino para ecsaminarl y ecsaminó el Organo de la Catedral de la presente, si corres-/pondia la obra al precio, y por consiguiente tendrá mas co-/nocimientos practicos para dicernir el tal plan y precio si/ corresponden â la obra que se pretende./ Este es nuestro parecer./ Gerona 15. Julio 1845./

Juan Carreras Pbro. y Org. ${ }^{\text {ta }} /$ Antonio Xandiera Pbro/ y Org. ${ }^{\text {ta }}{ }^{325}$

Com podem veure, els dos organistes diuen no posseir prou coneixements ni experiència i recomanen al capítol que

\footnotetext{
${ }^{324}$ Ll.R.C. 1843-1846, fol. insert a continuació del 26.

${ }^{325}$ Ll.R.C. 1843-1846, annex $\mathrm{n}^{\circ} 64$.
} 
demani parer a l'organista Mateu Ferrer. Succeeix, però, que el capítol no disposa de prou diners per a fer front a la reparació que proposa Portell i, una vegada més, ho han de deixar córrer.

Se leyó el informe de los dos organis-/tas arriba dichos y no pudiendo ellos decir/ lo q. ${ }^{e}$ puede costar la recompos. ${ }^{n} /$ de dictamen $q .{ }^{e}$ se consulte á Barcelo-/na despues de con las $q .^{e}$ debate sobre el/ particular y $q .^{e}$ cada capitular manifes-/tó su parecer haciendose cargo el $\mathrm{Cab}^{\text {do }} /$ de ser indispensable la comp. ${ }^{\text {on }}$ mas siendo/ una suma de considerac. ${ }^{n}$ se acordo, el in-/forme de los organistas vese al $n .^{\circ} 64 /$

Res. ${ }^{\text {on }}$ Que se suspenda por ahora el tratar/con el Organero sobre la comp. ${ }^{\text {on }}$ pagan-/dole el viage de venida é ida como tam-/bien lo q. ${ }^{e}$ hubiese gastado en los dias/que permaneció en esta interin tanto el/ Cabildo acudirá al Gobierno $p^{a}{ }^{a}$ afin de con-/seguir alguna cantidad $p^{a}{ }^{a}$ dicho gasto, pues/ que le [sic] Cabildo se halla exausto de fondos. ${ }^{326}$

L'any 1846, l'orguener Ramon Roquer passa per la ciutat i diu que l'afinarà, netejarà i arreglarà els registres trencats per tres-centes lliures. Com que no és un cost excessivament elevat, el capítol hi accedeix.

El S. Laudache propuso el $q .^{e}$ se hallaba en esta/ el Organero Ramon Roquer quien ha visto el Organo del esta Ygla el q. ${ }^{e}$ esta muy sucio y enteram. ${ }^{\text {te }}$ desafina-/do con algunos registros rotos el $q .^{e}$ se obliga á ponerlel corriente con

${ }^{326}$ Ll.R.C. $1843-1846,15$ de juliol de 1845 , fol. 26 v. 
tal q. ${ }^{e}$ el Cabildo de 300 ll y lo q. ${ }^{e}$ reste lo/ abonará dho S. Laudache./

Res. ${ }^{o n}$ Se admite la propuesta del S. Laudache y en su/ consequencia se comisiona á dho Sr. con el Can. ${ }^{g o}$ Aulet/ para llebar à efecto la limpia $y$ afinacion de to-ldo el Organo $p^{r}$ el factor Ramon Roquer p. ${ }^{r}$ la/ suma de $300 \mathrm{ll}$ q. $^{e}$ se le satisfaran asegurado $q .{ }^{e} /$ el organo quede corriente en la censura quel se hará al fin de la Comp. $^{\text {on }}$ y $q .^{e}$ el Organistal este a la vista interin se limpie. ${ }^{327}$

Ens trobem al mes de novembre de l'any 1847; tot i que fa un any de la darrera reparació, aquesta no havia estat feta amb profunditat i l'orgue no funciona com hauria de funcionar. Llavors decideixen tornar a escriure l'orguener Antoni Portell, que està arreglant l'orgue de Blanes, després d'haver-ho fet amb el de la col-legiata de Sant Feliu, sol-licitant-lo per que repari el de la catedral.

El Can. ${ }^{g o}$ Hurtado junto con el S. Laudachel como à obreros hicieron presente $q{ }^{e}$ con motibo del estos ambos enfermos, y no haber podido asistir/ en el Cabildo anterior combocan á VS p. ${ }^{a}$ mani-/festar dos proposiciones à saber la $1^{a} q^{e}{ }^{e}$ viendo/ que el organo de esta Ygla con la afinacion $q .{ }^{e} /$ poco hace se hizo en el no suena como debe/se abistaron con el organero $q{ }^{e}$ arregló el de la/ Colegiata de S. Felix, y si parece bien à V.S. se po-/dria contratar con el mismo sacando los registros/de los Clarines á fuera q. ${ }^{e}$ sonarian mucho mas/ cuia composicion dijo subiria á $6000 \mathrm{ll}$. y q. ${ }^{e} /$ el tal organero se ha-llaba en Blanes arre-/glando el

${ }^{327}$ Ll.R.C. $1843-1846,14$ de gener de 1846 , fol. 35 . 
de aquella comunidad, y se mar-/chará en seguida á Mallorca si VS no aprove-/cha esta ocasion, $p .^{r} q .^{e}$ se ha bisto entiende en/ el arte de construir los organos./

Res. ${ }^{\text {on }} \quad$ Placet $y$ q. ${ }^{e}$ dhos SS. Ob. ${ }^{s}$ escriban al Organerol pase á esta p. ${ }^{a}$ quedar á cordes encargandose los/ mismos de su buena composicion y si hubiese del gastarse algo mas $p .^{a}$ su mejor construccion quedan/ facultados p. $^{a}$ ello. $^{328}$

Estem a tres de març del 1848 i el capítol ha accedit a que es faci la reparació. Entre altres coses, treuen els tubs dels clarins a fora per a que l'instrument tingui més sonoritat.

El Can. ${ }^{g o} \mathrm{Sr}^{i o}$ manifestó $q .{ }^{e}$ le sorprendió el / ver $q .{ }^{e}$ la armazon del organo $q .{ }^{e}$ se está arreglan-/do $p^{a}{ }^{a}$ estraer los clarines, esta sostenido $p .^{r}$ dos co-llumnas de hierro, $q .^{e}$ la una se sostiene sobre la bran-/dilla del coro, y la otra sobre la cornisa, y q..$^{e}$ esta/ desigualdad hace mala vista, y afin de ber si/ dichas columnas quedarian asi, me abisté con ell Organero, $y$ dijo $q .{ }^{e}$ si; mas $q .{ }^{e}$ no eran necesarias/ sino q. ${ }^{e}$ un S. Capitular se lo adbirtió debia poner-/las $p .^{a} q^{e}{ }^{e}$ estubiese mas segura a lo $q{ }^{e}$ conteste esta-/rian mas disimuladas si se pusieran unos tirantes/ de hierro en lugar de dichas columnas mas $q .{ }^{e} /$ lo manifestara á VS p. ${ }^{a} q .{ }^{e}$ resolbiese lo $q .{ }^{e} /$ mejor le parezca.l

Res. ${ }^{\text {on }}$ Se conforma el Cabildo con $q .^{e}$ se pongan los/ tirantes y no las columnas si puede ser

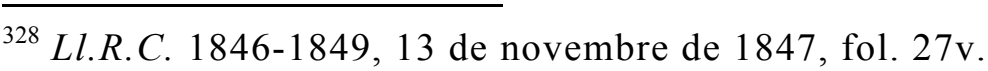


dejan/ en libertad al organero $p{ }^{a}{ }^{q} \cdot{ }^{e}$ lo haga del mo-/do que mejor le parezca no tomando parecerl de Capitular alguno tan solo de los Obreros/y de resolucion del Cabildo. ${ }^{329}$

El mismo S. Presid. ${ }^{\text {te }}$ dijo combocaba á VS/ porque los SS obreros le manifestaron q. ${ }^{e}$ solo/ faltaba el afinar el organo cuia operacion/ segun el mismo organero dice seria de unos 15/ dias y como el organero tiene precision del marcharse les indico si pudiese trabajar to-/dos los dias seguido seria mas pronto afinado/ $p^{r}$ que si tiene de suspenderla afinacion du-/rante las horas de coro tendria mucho/ mas tiempo y $q .{ }^{e}$ se le seguian grandes perju-/icios en vista de lo qual proponian se po-/dria durante dho tiempo de afinacion tras-/ladarse el Coro a la Capilla de la Esperanza co-/mo se tiene berificado otras veces./

Res. ${ }^{\text {on }}$ Se conforma el Cabildo [...]. ${ }^{330}$

I amb aquesta, hem arribat a la darrera notícia referent a l'orgue gran de la catedral de girona, durant el període $1800-1850$.

\section{ELS ALTRES ORGUES}

\section{a) L'orgue petit o de semidobles.}

Surt mencionat diverses vegades com a "organo pequeño". Utilitzaven aquest orgue en les festivitats

\footnotetext{
${ }^{329}$ Ll.R.C. 1846-1849, 3 de març de 1848, fol. 31.

${ }^{330}$ Ll.R.C. 1846-1849, 13 de març de 1848 , fol. $31 \mathrm{v}$.
} 
semidobles, festes de grau intermedi. Fou destruit durant la Guerra Civil de 1936-39.

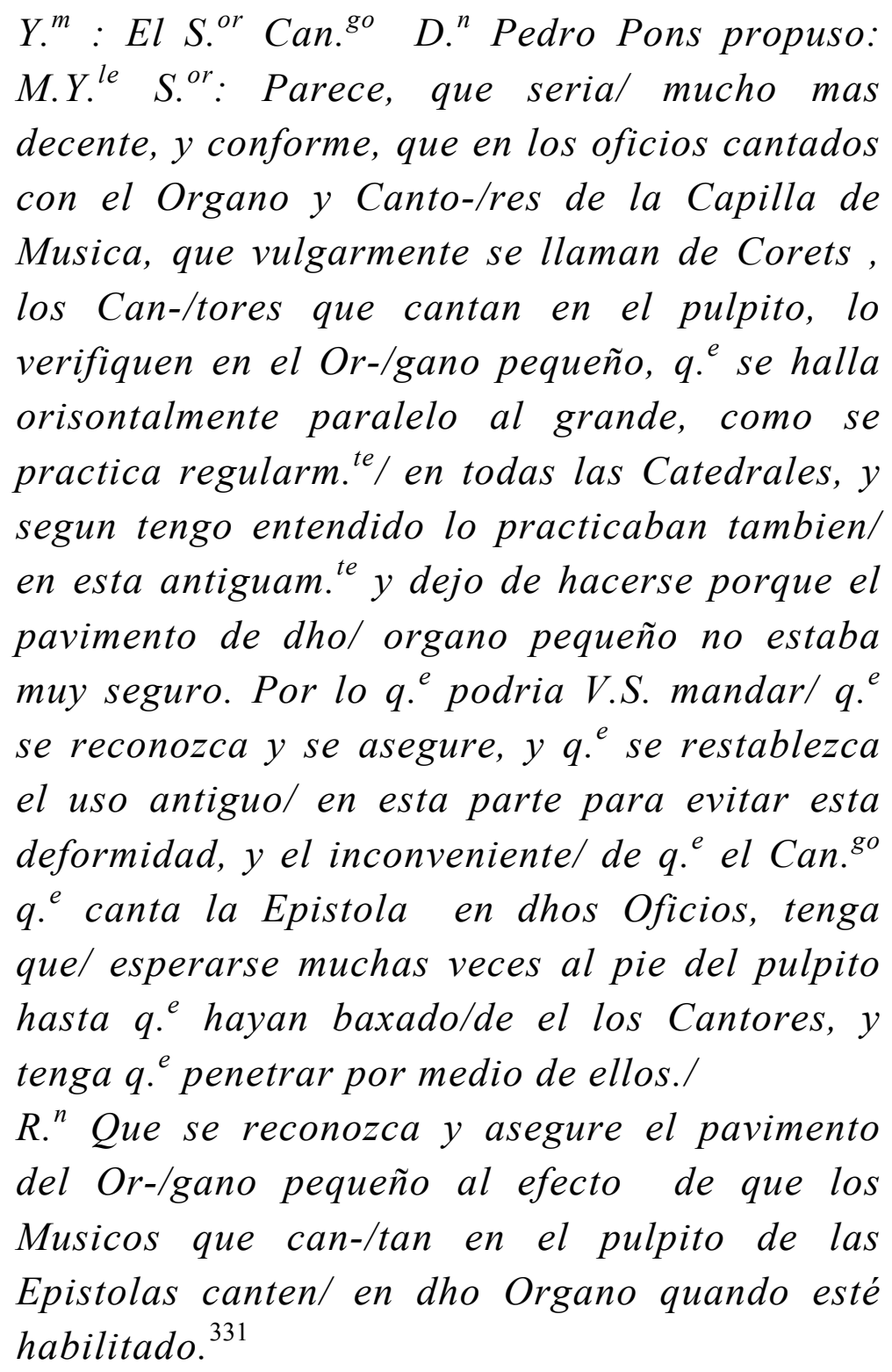

\section{b) L'orgue de la capella de l'Esperança.}

Aquest instrument sembla que encara fou vist pel mestre Francesc Civil i els seus coetanis. Com l'orgue de

${ }^{331}$ Ll.R.C. 1817-1819, 4 d'abril de 1818, fol. 69. 
semidobles, quedà totalment destruït, com a conseqüència de la Guerra Civil del 1936-39. ${ }^{332}$

Surt citat en l'acta capitular de divuit de gener de l'any 1799 , en el document que transcric a continuació :

Itt: Lei un memorial de Fran. ${ }^{c o}$ Vilella Organero del la presente Ciudad, solicitando testimonio del haber arreglado los quatro Org. ${ }^{s}$ de esta Ygla. à sa-/ber el mayor, el de Semidobles, el de la Capilla de la/ Esperanza, y el portatil, $y$ de haberlos dejado corrien-/tes. ${ }^{333}$

Tot i l'ingent quantitat de fonts consultades, aquest orgue no torna a sortir citat cap més vegada.

\section{c) L'orguenet portàtil}

Aquest orgue s'utilitzava en diverses funcions, en un gran nombre de processons i en la nit de Nadal.

\footnotetext{
${ }^{332}$ Pel que fa a la ubicació d'aquest orgue, les informacions trameses pel mestre Civil es contradiuen. D'una banda en el llibre El fet musical...,., Ob.cit., p. 47, a propòsit dels orgues de la catedral diu que: “un altre instrument, mitjà a la capella de l'Esperança, a l'entrada del claustre, i que hem aconseguit de veure si bé totalment inservible, ja no existeix". I en l'article "El organo y los organistas de la Catedral de Gerona durante los siglos XIV-XVI", Ob.cit, p. 227 i 228, dubta en si l'orgue està situat en la capella de l'Esperança, a l'entrada del claustre; o ubicat en una de les parets del claustre. En el citat article diu: "I ${ }^{\circ}$ : el más pequeño, emplazado en los claustros, o quizás en la capilla de Nuestra Señora de la Esperanza, contigua a la puerta de entrada a los mismos; tratábase de un pequeño instrumento que hemos visto, aunque sin pulsarlo, en la pequeña tribuna de dicha capilla y que en 1936 fue destruido, o mejor dicho, dispersados sus restos."

${ }^{333}$ Ll.R.C. $1798-1800,18$ de gener de 1799, fol. 22.
} 
It, paga per portar lo Orga petit, $\ddot{y} /$ manxar la Nit de Nadal... 1 ll 44

It, paga per portar lo orga petit, $\ddot{y}$ Manxador/

en las profesons generals per cada vegada, $q .{ }^{e}$ se fal

per la Ciutat... Ill.. _.. s/

per la Ygla..............2.. s/

..1ll.. 2.. s. ${ }^{334}$

Sembla ser que durant els setges, duen aquest orguenet a casa del mestre de capella, per tal d'evitar que es faci malbé. A principis de juny del 1809 , el tornen a dur cap a la catedral.

Compte del que ha treballat Leopoldo Pagès fuster per la Stal Yglesia Catadral de Gerona des del primer de jun̈̈ 1809 fins lo ultim / Xbre [octubre] de dit Anÿ [...]/

$m^{s}$... per traurer lo orga petit de Casa al Sr/ Mestra de Capella $\ddot{y}$ la Trona $\ddot{y}$ los Caballs del/Catafal... ll $15 \mathrm{~s}^{335}$

Aquest instrument fou lliurat a l'orguener Honorat Grinda, com a part del pagament de la important reconstrucció de l'orgue gran, que es realitzà l'any 1830 , ja que es posaren registres nous que no entraven dins del pressupost (vegi's el capítol de l'orgue).

Cabildo extraord. ${ }^{\circ} /$

El S. ${ }^{r}$ Canonigo Toronell hizo prte., $q .^{e}$ en virtud de la contrata otorgada con el/ Organero Grinda debia entregarsele el organo pequeño;

\footnotetext{
${ }^{334}$ Ll.C.O. 1815-1817, fol. 59.

${ }^{335}$ Ll.C.O. 1809-1815, annex $\mathrm{n}^{\circ} 3$.
} 
pero $q^{e}{ }^{e}$ el no querial verificarlo sin obtener antes el permiso del Cab. ${ }^{\circ}$ I

$R .^{n}$ Entreguese el mencionado organo à dcho. Grinda, procurando sacarlo en ho-/ras en $q .{ }^{e}$ no haia residencia. ${ }^{336}$

Tanmateix, tornem a tenir notícia d'un "organillo" en les actes capitulars de l'any 1841. Segurament es tractaria de l'adquisició d'un nou instrument, doncs tot i que en aquestes dates la capella pràcticament havia desaparegut, l'ús de l'orguenet en determinades funcions, era important.

El Can. ${ }^{g o}$ Srio dijo M.Y.S. el motivo de combocar ál V.S. es por haverse presentado el Organista de esta Sta. Ygla./ pidiendome hiciese presente á V.S. q. el Maestro de Capillal de esta misma Ygla le habia prebenido $q .{ }^{e}$ no tocase el/ Organillo en las $40 \quad$ horas en los intermedios de los Sermones/ y en su defecto le despediria de la Capilla cuio motivo es $.^{r}{ }^{r} q .^{e}$ los SS q. ${ }^{e}$ tienen las horas de dhas 40 no tienen musica/ como los demas años $p^{r}$ haberla aumentado el Maestro/ $y$ asi lo manifiesto a V.S. p. ${ }^{a} q .{ }^{e}$ decida resolver./ Res. ${ }^{\text {on }}$ Se los q. ${ }^{e}$ tienen las horas de dhas $40 y$ co-/brar lo q. e sea regular por su trabajo. ${ }^{337}$

\footnotetext{
${ }^{336}$ Ll.R.C. 1829-1831, 3 de juliol de 1830, fol. 33.

${ }^{337}$ Ll.R.C. 1840-1843, 3 d'abril de 1841, fol. 10.
} 


\section{ALTRES INSTRUMENTS DE LA CAPELLA}

\section{a) El manacord}

El mestre de capella tenia aquest instrument a casa seva i l'utilitzava per a donar lliçons de solfeig als escolans del cor.

El dia tres de març del 1836 tenim la notícia que un dels escolans vol fer aprendre a tocar l'orgue i llavors, per tal de poder-li ensenyar, l'organista demana al capítol el "menacor" que es troba a casa del mestre de capella,

[...] si el Cabildo tubiese a bien disponer que $p^{a}{ }^{a} /$ ello se le entregase el instrumento Menacor [sic] propio del Cabildo/ que obtiene en el dia el Maestro de Capilla/ [...]. ${ }^{338}$

L'organista marxarà al cap de dos anys, però abans donarà el manacord i les claus a l'organista interí.

Los Señores Compta y Murtra dijeron $q .^{e}$ el Organista se ha-/bia marchado, y $q .^{e}$ no habia cumplido con lo $q .^{e}$ el Cabildo lel habia mandado, y si q. ${ }^{e}$ habia recibido el adelanto $q .{ }^{e}$ el Cabildo le ha-/bia concedido como tambien habia dejado las llaves, y un Manu-/cordio al Organista interino./

Res. $^{\text {on }}$ que los dichos Señores digan al Organista interino ${ }^{339}$ si necesita el/ Manucordio, ó no, y en caso lo necesite entrege un recivol

\footnotetext{
${ }^{338}$ Ll.R.C. 1835-1837, 3 de març de 1836, fol. 20v.

${ }^{339}$ Es refereixen a Bernat Papell.
} 
como recivió el tal Manucordio durante el beneplacito del Cabildo. ${ }^{340}$

\section{b) El contrabaix}

En els Llibres d'obra apareixen molt sovint les despeses ocasionades per les reparacions del contrabaix i l'adquisició de cordes. És curiós veure que el mestre fuster que solia arreglar els instruments de la capella s'anomenés Ramon Hilla, i com veurem en el cas d'altres instruments, també en fabricava o venia. Segurament aquest Ramon, fuster i luthier, era un familiar dels quatre germans Illa, músics seglars de la capella.

Comte de la Compostura del Contrabä̈x del Yl. ${ }^{\text {tre }} /$ Capitol./

Per Adobar-lo $\ddot{y}$ Adovar lo Batidor........ 5 ps./

Per posar pels Nous en lo Arch.............. 3 ps/

Per un ancordat Nou..........................16 ps/

Suma 24 ps/

Gerona â 17. Juñ 1820/Ramon ÿlla M. ${ }^{\text {tre }}$ fustel Pagat â 20 Juny 1820. ${ }^{341}$

A partir de cercar documents que fessin referència al contrabaix de la capella, hem trobat un document en el que surt de manifest un dels aspectes de l'ambient musical de la Girona del vuit-cents. Es tracta de les funcions musicals que se celebraven determinats dissabtes al matí, petits concerts interpretats per joves afeccionats a la música, que aristòcrates i persones adinerades, organitzaven a casa

\footnotetext{
${ }^{340}$ Ll.R.C. 1837-1840, 10 de setembre de 1838, fol. 33.

${ }^{341}$ Ll.C.O. $1815-1817$, dins un lligall granate sense inscripció, fol. 6.
} 
seva. Aquestes funcions eren anomenades amb el mot acadèmia ${ }^{342}$.

4. ${ }^{\circ}$ El Hijo Mayor del S. ${ }^{\text {or }}$ Marques de Campmany de esta/ Ciudad pide, se le dexe el contrabaxo propio de la Ca-/pilla de esta Sta Yglesia p. ${ }^{a}$ las Academias de Musical q. ${ }^{e}$ todos los sabados de esta Quaresma celebran en su/ propia casa varios aficionados, con responsabilidad/ de dha prenda./ Resol. ${ }^{n}$ Concedido. ${ }^{343}$

\section{c) Les trompes}

El capítol també disposava de dues trompes; normalment es feien servir totes dues, doncs la capella solia tenir dos instrumentistes de trompa. En les èpoques que només hi havia un instrumentista, escolans de cor o altres músics solien demanar la trompa lliure per a aprendre la tècnica de l'instrument.

Itt: Fran ${ }^{c o}$ Riumbau Escolan de la Sacristia de V.S./pide el favor de una Trompa q. ${ }^{e}$ tiene/ la Iglesia, para exercitarse en su manejo/ Res. Que los SS. Comisarios de Musica determinen lo/ que les pareciere en particular. $^{344}$

\footnotetext{
${ }^{342}$ Vegi's al capítol II, l'apartat 6.a de "Les funcions musicals de la capella".

${ }^{343}$ Ll.R.C. 1821-1823, 2 de març de 1822, fol. $91 \mathrm{v}$.

${ }^{344}$ Ll.R.C. 1800-1803, 22 de gener de 1803, fol. $352 \mathrm{v}$.
} 


\section{d) Els ministrers}

El capítol tenia dos tibles, una tenora i un sacabutx; aquests instruments constitueixen el que s'anomenava "cobla de xirimies" i també eren mal anomenats "ministrils". Els dos tibles solien realitzar els papers de soprà i contralt, la tenora el de tenor, i el sacabutx el de baix. Desapareixen amb els setges, i l'any 1814, en què els francesos desocupen Girona i es restableix la capella, els músics demanen que se n'adquireixin de nous, doncs els necessiten per a diverses funcions. S'utilitzaven principalment en les terceres dominiques i en els viàtics.

Itt: El S. ${ }^{\text {or }}$ Dorca propuso: Que de la Obra se paguen/ algunos instrum. ${ }^{\text {tos }} q .^{e}$ dicen los Musicos se nece-/sitan para las terc. ${ }^{s}$ Domin. ${ }^{s} y$ algunas otras festi-/vidades de la Yglesial Res. Que ya se asiste à la Capilla con el Contrabajo,/ que se costea por la Obra, que se vea si el saca-/buig, ô alguna otra cosa de estas se ha de pagar/ por la Obra, y q. el S. ${ }^{\text {or Junca }}$ talvez sabra lo quel hai en el particular ô el Mtro. de Capilla. ${ }^{345}$

No podran ser comprats fins al disset de febrer de l'any 1815, i són adquirits al torner Ramon Hilla, el mateix personatge que s'ocupava d'arreglar el contrabaix.

Comta de lo que Io Ramon hilla/ torner tinch treballat per lo Mü// Yllustre Capitol de Geronal

Pmo. Per dos tipbles à sis/ duros quiscun son 12 duros/

$2{ }^{n s}$ per un tenor...8 duros/per lo Sacaputxo y/ Boquilla... 2 duros i mitx/

${ }^{345}$ Ll.R.C. $1812-1815,19$ de novembre de 1814 , fol. $114 \mathrm{v}$. 
suma 22 duros i mix/

Lo señor Ille. Can. ${ }^{e}$ Obrer servesques pagar/lo sobredit Compte. Gerona 17 febrer 1815/ Jph Torrent Can. ${ }^{e}$ Comissaril Jph Dorca Can. ${ }^{e}$ Comissari/Tinch rebut del Sr. Obre lo Soba-/dit 22 y mitx. Gerona 17 febrer 1815/

Ramon hilla Torner. ${ }^{346}$

\section{ELS LLIBRES DE COR I LES PARTITURES}

En l'estudi dels documents de la capella, he trobat algunes referències als llibres de cor $\mathrm{i}$ a les partitures emprades pels músics. Els llibres de cor contenien cant pla $\mathrm{i}$ algunes peces polifòniques. Havien de ser renovats de tant en tant, a causa del seu ús freqüent.

El setze d'abril de l'any 1804 , hi ha la petició de l'organista del convent de dominics de la Seu d'Urgell, oferint-se a copiar els llibres de cor deteriorats.

Itt: Ley otra Carta del P. Fr. Pablo Hernandez/ Dominico Organista del Convento de Dominicos/ de Urgel, solicitando $q .^{e}$ el Cabildo le empleel en la copia de los Libros de Coro, que se hallen/ deteriorados, y $q .^{e}$ ha sido empleado por varias/Iglesias con aprobacion; y que para mayor/ satisfaccion del Cabildo esta pronto à remitir/ [68v] muestras de la letra $q .^{e}$ emplea./

Res. Que se tendra presente esta Carta, pero q. ${ }^{e} /$ por ahora no hai disposicion de hacer

${ }^{346}$ Ll.C.O. 1813-1815, full solt $\mathrm{n}^{\mathrm{o}} 23$. 
estas/ obras, a causa de atender à otros gastos. $^{347}$

La segona informació és de l'any 1815. El setze de setembre un dels canonges comissaris de música, el $\mathrm{Sr}$. Cufí, demana als escolans que facin guàrdia davant la porta dels apòstols, per evitar que els nois que capten s'entretinguin en fer malbé els llibres de cor.

Yte. El Sr. Canonigo Cufí propuso que, habiendose observado, que se malbarataban los libros de Coro, hallandose rasga-/das y cortadas algunas de sus hojas de pergamino, y que es-/to debia atribuirse a los muchachos mal entretenidos quel de ordinario piden limosna en la puerta de los Apostoles/ y entran a la Ygla quando les parece, debia ponerse re-/medio, y que á su parecer no habia otro mas oportuno/ que mandar a los Escolanes que estan de guardia quel alomenos uno no separe un momento ni deje dicha/ guardia ahun el tiempo de comer, y que saquen a los/ indicados muchachos del Portico de los Apóstoles, no permi-/tiendoles acerquen a el./

Resol. Que se haga como propone el Sr. Cufi $[\ldots]^{348}$

Pel que fa a les partitures, hi havia dos armaris, un a la catedral i l'altre dins la casa del mestre de capella. Sembla ser les partitures generals quedaven a l'armari de la capella, que estava a la catedral, $i$ que les còpies $i$ particel-les, quedaven a l'armari que hi havia a casa del mestre de capella. Els comissaris de música eren els

\footnotetext{
${ }^{347}$ Ll.R.C. 1803-1807, 16 d'abril de 1804 , fol. 68 i $68 \mathrm{v}$.

${ }^{348}$ Ll.R.C. $1815-1817,16$ de setembre de 1815 , fol. $27 \mathrm{v}$.
} 
encarregats de fer inventari de les partitures i els instruments propietat del capítol, cada vegada que hi havia un canvi de mestre. Era obligat que tota composició, nova o vella, interpretada per la capella quedés guardada en un d'aquests armaris.

Referent al manteniment de partitures i particel-les, segons l'ordinació número cinc, de les ordinacions de la capella de música de l'any 1737, era obligació del mestre de capella copiar les partitures que pel seu ús s'haguessin deteriorat.

$5^{o}$...Tindrá la obligació [...] re-/[v]nobar los papers de Musica del armari, copiant los quel per lo desmasiat us se han fet $\hat{o}$ se fan inservibles.

La informació del vint-i-dos d'octubre de l'any 1819 fa referència a l'inventari dels papers de solfa, utensilis $i$ mobles, que feren els comissaris de música a la casa del mestre de capella, quan el mestre Honorat Verdaguer deixà la catedral gironina.

$2^{\circ}$ Los S.S. Canónigos Comisionados para tomar inventario de las halajas, muebles y/ armario de los papeles de Solfa de la Casa del Maestro de Capilla habitada hasta el dial presente por el $R$. Honorato Verdaguer exMaestro de dicha Capilla, hacen presente,/ haber tomado dicho inventario y que todo está conforme se entregó en su ingreso al referido $R$. Verdaguer/.

Resolucion. Para inteligencia. ${ }^{349}$

${ }^{349}$ Ll.R.C. 1819-1821, 22 d'octubre de 1819, fol. 20. 
Però, tal i com es diu en la darrera informació, sembla ser que no tot estava correcte, ja que trobaren a faltar algunes partitures. El president del capítol de canonges diu que se li embarguin les pertenències que encara li resten a la casa, fins que no torni les partitures.

Ytem. Hizo presente el Secretario que el $R$. Honorato Verdaguer se havia llevado [fol. 21v.] varios papeles de música, que debía dexarlos en el armario/ de la Capilla o en la misma casa propia del maestro de Capilla del Música de esta Sta. Ygla./

Resolución. Que se le despache un mandato; y que se le embarguen sus muebles/ que todavía existen en la casa que habitaba, junto/ con los emolumentos que acreditó en la administración de los Aniversa-/rios, hasta la entrega de dichos papeles. ${ }^{350}$

La tercera informació exemplifica la norma, consistent en que tota composició interpretada per la capella, ja fos nova o vella, quedés guardada en l'armari de la capella. El document del vint-i-dos d'agost de l'any 1828, fa referència a la petició d'un particular. Aquesta consistia en que es cantés amb la capella un Rosari nou de la seva propietat, sense voler que aquesta partitura quedés guardada a l'armari de la capella.

El Sr. Mató Comisario de musica dijo: que teniendo un parti-/cular de la Ciudad un Rosario (en musica) nuevo, se solicitaba se toca-/se y cantase con la Capilla en la Ygla de los Dolores, negan-/dose a dejar la Composicion nueva en el Armario de Capilla

${ }^{350}$ Ll.R.C. 1819-1821, 30 d'octubre de 1819, fol. 21 i $21 \mathrm{v}$. 
según costumbrel

Resolución. Que toda composicion musica que se toque, y cante por la Capillal de esta Sta. Ygla (sea de quien fuese) quede en el armario del la Capilla de Musica, sin cuya circunstancia no estara obligado/ el Maestro a tocarla, o cantar, conservese por los SS. Comisarios de musical un ymbentario de los instrumentos, piezas de musica y demas/ efectos de la Capilla añadiendo toda vez que haya nueva composición. ${ }^{351}$

\section{VIVENDES PROPIETAT DEL CAPÍTOL}

La seu tenia múltiples propietats, terres, masos $\mathrm{i}$ vivendes dins la ciutat de Girona; tots aquests béns foren venuts i traspassats a l'estat durant les desamortitzacions de Mendizábal i posteriorment de Madoz, a partir de l'any 1833. Per tant els documents a que faré referència són anteriors a aquesta data.

Entre els documents consultats, surt citada diverses vegades la casa del mestre de capella, que era propietat del capítol $^{352}$. Segons es desprèn de la lectura del següent document, aquesta casa tenia hort.

$2^{\circ}$ El Sr Canonigo Aulet pide al Cabildo, quemientras no se habita/ la casa de su vecino el Maestro de Capilla [...]/ tenga V.S. a bien dejarle cuidar sus huertos [...]/

${ }^{351}$ L1.R.C: $1827-1829,22$ d'agost de 1828, fol. $31 \mathrm{v}$.

${ }^{352}$ Sobretot quan hi ha canvi de mestre i els canonges comissaris de música fan el pertinent inventari. Vegi's en aquest mateix capítol, l'apartat dels llibres de cor i les partitures. 
Resol. ${ }^{n}$ Se concede al referido $\mathrm{Sr}$ Canonigo Aulet cuidar de los huertos; y/ de la casa del Maestro de Capilla, durante la ausencia de este, $[\ldots]{ }^{353}$

Cal dir que alguns mestres de capella deurien fer treballar els escolans en aquest hort, ja que en les Obligacions que deu cumplir lo Mestre de Capella ${ }^{354}$, que el capítol donà al mestre Honorat Verdaguer l'any 1819, la número nou deia exactament

Se abstindrá de fer treballar los Escolans en lo Hort. $^{355}$

S'ha trobat un altre document que fa referència a la casa de l'orguener, que també era propietat del capítol. Aquesta estava situada a la baixada de Sant Feliu, molt aprop de la catedral. En aquest cas, l'orguener pagava un lloguer per a poder-hi viure.

Itt: Ley otro Memorial de Francisco Vilella organero de estal Ciudad, suplicando que el Cabildo le arriende la Casa, quel tiene à la bajada de Sn. Feliu, en virtud de haber falle/cido Narciso Puig fuester [sic], que la habitaba $y$ es del Feriall

Res. Que pase este Memorial al Administrador del/ Ferial. ${ }^{356}$

\footnotetext{
${ }^{353}$ Ll.R.C. 1821-1823, 2 de març de 1822, fol. 91v.

${ }^{354}$ Vegi's aquest document complet, en el capítol II, en l'apartat dels Mestres de capella i escolans.

${ }^{355}$ Ll.R.C. 1817-1819, 2 de gener de 1819, carta inserta abans del fol. 131.

${ }^{356}$ Ll.R.C. $1803-1807,6$ de gener de 1806 , fol. $332 \mathrm{v}$.
} 
La següent informació fa referència a l'estància on dormien els escolans de cor, que estava situada damunt de l'orgue gran.

[...] Los Canonigos ocuparon los quartos de los Escola/nes, que estan, subiendo la escalera del Organo/ mayor, y caen sobre las Sacristias $[\ldots] .{ }^{357}$

El divuit d'abril de l'any 1807, el capítol donà uns diners a l'organista Antoni Guiu, per ajudar-lo a instal-larse a Girona. És l'únic document en què consta una ajuda per aquesta situació.

Itt. Ley otro Memorl. del R. Antonio Guiu Pbro./ Organista de esta Sta. Yglesia suplicando al Cabo./ tenga â bien hacerle alguna gratificacion por/ una sola vez, mediante los gastos $q .{ }^{e}$ tiene $q .{ }^{e} /$ sufrir para poner casa./

Res. Que se le den cien libras de los caudales/ de la Obra por una sola vez. ${ }^{358}$

357 Ll.R.C. 1807-1812, 12 de juny de 1809, fol. 193v. Aquest document està complet en l'apartat que parla de l'orgue gran.

${ }^{358}$ Ll.R.C. $1807-1812,18$ d'abril de 1807 , fol. 18. 


\section{APÈNDIX \\ DOCUMENTAL}


1. - Proposta de canvi en l'hora de les matines, del 23 de desembre de 1805 .

Itt: El Sr Presidente propuso. M.I.S. en el ultimo Cabildo/ de Coro quedo acordado, que en el primer Cabildo Ordinario/ se tratase de arreglar el punto de residencia; pues/ parece que el tiempo se inclina a bonanza, y quel ha cesado el motivo de haverse esta variado o/ alterado los dias pasados por las nieves./

Res. Que se vote sobre este asunto. Dicho Sr.Presidentel dixo no soi de voto que se inove el metodo de las horas/ [fol.234] segun esta establecido, ni en orden al canto en/los dias ordinarios; pero con respecto à las Ferias, y/ Dominicas, se pudieran decir semitonados los Mayti-/nes pues de esta manera irian mejor, y no se fati-/garian tanto los residentes; y que acabados los Mayti-/nes en dichos dias se continue cantando como sel hace ahora. Siguieron votando los SS. capit. ${ }^{s}$ y sel noto variedad en los votos de suerte que fue necesaIrio poner los votos por escrito, y reducir la propuesta a estas simples palabras. Si se habian de/ variar las horas. Se paso a votar, y los SS. Presidentel Borras Molinas, Brandia, Velado Torres Valparis/ Perez Riumbau Cuffi: Dorca, Carbo ,Sastre, Manegat/ Viñas, Subias, Matute Dorca menor, Gimenez, fue-/ron de dictamen $q .^{e}$ se siguiese en todo como has-/ta aqui, pero que con relacion à las Dominicas/y Ferias en lugar del Cantico se substituyese/ un semitonado. Los SS. Torrent, Juncá, Peniten. ${ }^{\circ}$ Vilomara Represa Pallos Mirosa, Bonet, quel se estableciese un nuevo orden. Prevaleciendo/ el mayor numero de Votos, quedando acordado 
quel se siga como hasta aqui; y que para tratar/ sobre ferias y Dominicas queden Comisionados/ los SS. Molinas, Valparis, Junca y Cuffi ${ }^{359}$.

\section{2. - Carta del canonge Rabal, del 27 de gener de 1806.}

Itt: Los SS. Molinas, Torrent, Juncà y Cuffi hicieron presen/te. M.I.S. en el Cabildo del 23 de Diciembre proximo/ pasado acordo V.S. à los Canonigos infraescritos, los quales en su cumpli/miento hacen presente, que se podran Cantar los/Maytines de la prim. ${ }^{a}$ Domin. ${ }^{c a}$ de Adviento, los de la Vi-/gilia de Navidad, y los del Miercoles de Ceniza: y sel podran semitonar todos los Mayitines de las demas/ Dominicas y Ferias, empezando à cantar el $\underline{\mathrm{Te}}$ Deum/ quando lo haya, y si no lo hai, se cantaran las Laudes/ y demas Horas, que se siguen, encargando à los So-/chantres, que entonen con gravedad, y cuiden se ha/gan los dos puntos, cuyo cumplim. ${ }^{\text {to }}$ deberia zelar el S. ${ }^{\text {or } / \text { Presid. }}{ }^{\text {te }}$ del Coro. Las horas de entrar à los Mayitines/ respectivas à los tiempos no se deben alterar. A los Maytines de las Dominicas de Quaresma en la en q. ${ }^{e} /$ haya Minerva, y en las Fer. Sextan., quando hay/ Penitenciales, bastara entrar à las siete, sinque seal necesarios empezarlos à tres quarto para las 7./ V.S. dispondra en todo lo que sea de su mayor agrado/ Gerona 23 de Enero de 1806. Miguel Molinas C. ${ }^{\circ}$;Joseph/ Torrent Canon. ${ }^{\circ}$;Fran. ${ }^{\text {co }}$ Junca C. ${ }^{\circ}$. Julian Cuffi Can. ${ }^{\circ}$

$\overline{{ }^{359} \text { Ll.R.C. 1803-1807, fol. } 233 \text { v i } 234 .}$ 
Altiempo de votarse sobre lo expuesto por los S.S. Co-/misionados el S. ${ }^{\text {or }}$ Rabal leyo un papel que tenia/ escrito al efecto, que literalmente es como se sigue./ Muy I.S. la novedad de quitar el Canto del Coro en/ las Dominicas y ferias, aunque se exceptuen algunas/ es prematura, porq. ${ }^{e}$ es variacion substancial y pro-/pia de Capitulos Generales./ [fol. 243] Ignoro q. ${ }^{e}$ se haya alegado causa, que la honeste: si fuesel porque rezado $\hat{o}$ semitonado seria mas descansado; ésta/ no es suficiente, y es la razon porque ya 1722. el modo del cantar se decia antiquisimo. Desde entonces ha habi-/do residentes robustos, y flacos; el rezo iba con mas devocion/y decoro, y pausa, que ahora, y no se sabe que nadie pensa-/se en suabizar por el medio de ahora la residencia del/ Coro. Ademas de q. ${ }^{e}$ no se buscaria la honoroficencia del/ Culto, como demostrare./Las Consit. ${ }^{s}$ del Coro formadas en 1722, y que se man-/dan observar todos los años justifican lo dicho; pues/ la del Num. ${ }^{\circ} 6$ se esplica asi: Antiquisimus in hacl Eccles. ${ }^{a}$ psalendi modus servetur: psalmodia non mul-/to protrahatur, se rotunde, una, hac viva voce dean-/tetur principium et finis (continua y concluye) talis/ omni decantatio demones, fugat, et Angelos ad adjut omium/ salutis invita /La del num. ${ }^{\circ} 11$ dice: Omnes in choro simul divinas/ laudes cantent, nemo sumissa voce, vel alio quovis/ modo singulariter oficium valeat recitare /Muchas veces en Cabildos Pascuales de reforma se han/ mandado cumplir estas constituciones, en prueba de que la/ voluntad de V.S. es que ha sido su observancia; pero la/ enmienda no siempre ha sido correspondiente, 
y se ha repetido lo mismo no hace muchos años; pero con el mismo/ desgraciado fruto; de modo que Yo en comun y en parti-/cular he hablado amistosamente à los Sustentores, haciendoles/ver, que con medio quarto de hora en cada mañanal de mas que de menos pendia el poder cumplir bien/ lo conocian; pero respondian, que algunos Canonigos/ decian lo contrario; de donde se originan los desorIdenes, por que todos piensan que tiene dominio paral [fol.243v] mandar, y solo deben tener resignacion, para arre-/glarse à lo dispuesto por V.S. Esto es un hecho, y va-/mos ahora à las consequencias de la pretendida variacion. [...] [fol. 244v]

Res. Que se este à lo resuelto, y plan presentado por/los SS. Comisarios. ${ }^{360}$

\section{3.- Documents relacionats amb els setges.}

1.

[...] Celebrar el dia de mañana un Te Deum/al glorioso Patron S. Narciso en accion de gra/cias por la victoria que nos ha concedido con/ su patrocinio contra las tropas francesas, que en/ el dia y noche de 20 à 21 del corriente mes/ querian a toda fuerza asaltar nuestra Ciu-/dad, y para suplicarle humilde y rendidamentel nos continue su intercesion delante del Sor. de los/ Exercicios en lo sucesivo. Que se prescindira del todo motivo de etiquetas, caminando todos al/ glorioso fin de salvar la Patria y la Re-

${ }^{360}$ Ll.R.C. $1803-1807$, fol. $242 \mathrm{v}, 243$ i $243 \mathrm{v}$. 
/ligion. Esperan la respuesta de V.S./ Res. ${ }^{n}$ Que el Cabildo condesciende $[\ldots]^{361}$

2.

[...] le suplica una Rogativa para el dia de mañanal â S. Narciso en su Capilla â fin de que Dios por su/ intercesion nos conceda la gracia de truinfar del nuestros enemigos, que nos tienen sitiados. El/ cabildo no ha recibido oficio acerca del particu-/lar, como es de stilo y practica en tales casos, / pero teniendo atencion $\hat{a}$ la urgente necesidad,/ y prescindiendo por ahora de etiquetas, podra V.S./ acordar esta rogativa si lo tiene à bien./

Res. ${ }^{n}$ Que se haga mañana esta funcion. ${ }^{362}$

3.

Propuso el $S{ }^{\text {or }}$ presidente el motivo de juntarse V.S. en/ esta ocasión es para tratar de hacer ô dejar/ de hacer la funcion acostumbrada con motivo de la festividad de la Asunta. Los peligros en $q .{ }^{e} /$ se halla esta ciudad con el enemigo à la vista/ cañoneandola y enviandola inumerables granadas y/ bombas y a los q. ${ }^{e} V . S$. podra acordar lo conven. ${ }^{\text {te }} /$ Res. $^{n}$ Que se suspenda la funcion acostumbrada. ${ }^{363}$

4.

Propuso el Presid. ${ }^{\text {te }}$ : La Junta Suprema de estal Ciudad por sus Indibiduos los SS. Canon. ${ }^{s}$ Cuffi y Pla-/nella suplica â V.S. tenga la bondad de

${ }^{361}$ Ll.R.C. 1807-1812, 25 de juny de 1808, fol. $121 \mathrm{v}$.

${ }^{362}$ Ll.R.C. 1807-1812, 8 d'agost de 1808, fol. 130.

${ }^{363}$ Ll.R.C. 1807-1812, 13 d'agost de 1808, fol. 130. 
cantar/ en la Capilla de $S .{ }^{n}$ Narciso un solemne Te Deum/ en accion de gracias por haber huido en la no-/che anterior el ex. ${ }^{\text {to }}$ Frances, dejando libre la/ Ciudad despues de 25 dias de Sitio./ Res. ${ }^{n}$ Que se cante esta misma mañana a las/ once $[\ldots]^{364}$

5.

El S. Presidente propuso: M.I.S. de resultas del/ bombardeo ha quedado el tejado de la Igla.l mui maltratado, y la escalera grande hal padecido tambien aunque no cosa notable./ Tambien han padecido las casas de V.S. unas/ mas otras menos, pero todas bastante./[p.131v] V.S. acordara lo conveniente[...]/ Por ultimo se hace preciso el que se buelba a entablar/ el Cantico, y lo demas que V.S. ha acostumbrado en el Coro, mediante â hallarnos libres del pe/ligro que nos amenazaba el Sitio del enemigo./ Res. ${ }^{n}$ Que desde luego se avise al Maestro de la Iglesial para que comience la Obra del tejado de la Bobedal por lo mas necesario para impedir que las llu-/vias causen detrimiento [...]/ [p. 132] [...] Ulti-/mamente que se prevenga â los Musicos, los Esco-/lanes y demas dependientes de la Iglesia, que desdel esta tarde se cantaran todas las horas, y se cele-/braran los Divinos oficios como se hacia an-/tes del Sitio; para q. asistan al/ Coro, â la Sacristia, à la torre, y donde tienen/ obligacion según lo executaban antes. ${ }^{365}$

\footnotetext{
${ }^{364}$ Ll.R.C. 1807-1812, 17 d'agost de 1808, fol. 138.

${ }^{365}$ Ll.R.C. 1807-1812, 18 d'agost de 1808, fol. 131 i 132.
} 
6.

Se leyo una carta de la M.I. Junta de esta Ciudad/ firmada por el S. Presidente Dn. Julian Bolibarl teniente del Rey dando parte al Cabildo de quel tenia decretado un oficio Solemne con Sermon/ y Te Deum â Sn. Narciso en su Capilla en/ accion de gracias por la retirada o fuga $q .{ }^{e} /$ hicieron los franceses abandonando el Sitio de esta/ plaza el dia 17 de los corrientes; y otra fun-/cion de Difuntos con oracion funebre en sufra-/gio por las Almas de los generosos defensores,/ que han muerto cuviertos de gloria afendien-/do esta Ciudad y la Patria. Y que el Cabildo/ tenga la bondad de encargarse de estas fun-/ciones, que se haran el jueves y viernes 25, y 26/ [p.131v] del corriente. $^{366}$

7.

Propuso tambien dcho S. Presid.te que en considera-/cion â las enfermedades que corren, y que los Medi-/cos son de parecer que las campanas se toqien/ poco siempre que ocurren entierros al fin de no/ contristar [sic] á los enfermos y sanos $[\ldots]^{367}$

8.

El S. ${ }^{\text {or }}$ Presidente propuso, que con motivo de la festividad/ de S. ${ }^{n}$ Fernando que celebra la Igla. mañanal Gen.' y Governador de esta plaza $S$. D. ${ }^{n}$ Mariano/ Alvarez recibe a todos los Cuerpos Militares, Caba-/lleros y demas

\footnotetext{
${ }^{366}$ Ll.R.C. 1807-1812, 20 d'agost de 1808, fol. 132 i 132v.

${ }^{367}$ Ll.R.C. 1807-1812, 21 d'abril de 1809, fol. $183 \mathrm{v}$.
} 
personas de distincion en celebri-/dad de los dias de nuestro amado Rey [...]. ${ }^{368}$

9.

Leyo el S. Presidente una Carta que le habia en-/tregado el Sindico de la Ciudad; exponiendo que / el Ayuntamiento, suplicaba al Cabildo tubiese lal devocion de celebrar mañana 5 un oficio de /Rogativa a N. Patron y Generalisimo Sn./ Narciso implorando su patrocinio en esta oca-/sion critica, hallandose la Ciudad Sitiada/ del enemigo. ${ }^{369}$

10.

Nota: En el dia 14 de este mes, dadas las doce de la noche em-/pezaron los Franceses el Bombardeo contra estal Ciudad con un furor que dificilmente se puede expli-/car. Los vecinos, que pudieron, se refugiaron â esta Sta. Iglesia, acomodandose en sus Capillas, Claustros,/ Torre, Sacristias, y demas lugares â prueba de bom-/ba. Los Canon. ${ }^{s}$ ocuparon los quartos de los Esco-/lanes, que estan, subiendo la escalera del Organo/ mayor, y caen sobre las Sacristias; bien $q .{ }^{e}$ lal mucha gente, que concurrio â este lugar, los tu-/bo sumamente incomodados; pero era necesario sufrir-/lo todo por el bien de los vecinos. ${ }^{370}$

\footnotetext{
${ }^{368}$ Ll.R.C. 1807-1812, 29 de maig de 1809, fol. 191.

${ }^{369}$ Ll.R.C. 1807-1812, 4 de juny de 1809, fol. 192.

${ }^{370}$ Ll.R.C. $1807-1812,12$ de juny de 1809 , fol. $193 \mathrm{v}$.
} 
11.

Propuso el S. Cuffi en nombre de la Junta del esta Ciudad, que en virtud de la Gloriosal defensa $q .{ }^{e}$ habia hecho Monjuich, recha-/zando en la mañana de este dia al Ene-/migo despues de tres asaltos, cuya funcion/ terrible $y$ sangrienta duro dos horas, se can-lte â las once un solemne Te Deum con mu-/sica./ Res. ${ }^{n}$ Placet $[\ldots]^{371}$

12.

Cantar el te Deum:/ Solemne te Deum en accion de gracias por la tomal de esta Ciudad verificada el dia 10 del corriente./

Res. ${ }^{n}$ Que responda que el Cabildo esta pronto a cumplir la orden $[\ldots]^{372}$

\section{4. - Supressió oficial de les capelles de música, del 20 d'octubre de 1842.}

El Exmo. Sôr. Ministro de Gracia y Justicia con fecha de 14 del los corrientes me traslada la orden siguiente:/ Ministerio de Gracia y Justicia: Con esta fecha digo al Sôr. Mi-/nistro de Hacienda lo que sigue: De orden del Regente del Reyno/ remito à $S$. Ex. la adjunta relacion de las cantidades en que se han/ fijado por ahora, los presupuestos del Culto conservacion de los Tem-/plos y de los Palacios Episcopales de las Yglesias que se espresan/ en la misma, siendo al propio tiempo la voluntad de S.A. hago/ presente á V.Ex. que habiendose

${ }^{371}$ Ll.R.C. 1807-1812, 8 de juliol de 1809, fol. 195.

${ }^{372}$ Ll.R.C. 1807-1812, 7 de desembre de 1809, fol. 213. 
reducido aquellos todo lo posible li-/mitando los gastos á lo estrictamente necesario quel por ese Ministerio se desplegue el celo y la actitud mas incan-/sables à fin de que dando à semejantes consignaciones la preferen-/cia que corresponde al objeto à que se aplican, sean satisfechas/ con toda puntualidad por mensualidades ò tercias según se creal mas conveniente para lo cual deberán espedirse las ordenes opor-/tunas á los Yntendentes de las respectivas provincias encargando-/les miren con especial consideracion tan sagradas atenciones. Al / trasladar á V.S. la preinserta co-/ municacion, me manda S.A. lel haga presente que habiendose adoptado previamente al ecsamen/ y aprobacion de los presupuestos, como bases generales y comunes/à todos,

$1^{a}$ la de suprimir los gastos que no sean precisos, espe-/cialmente los que ocasionen las Capillas su-/primir y reducir cierto numero de sirvientes y de empleados quel no han parecido necesarios, asi como sus asignaciones en la que se ha considerado escesiva; se ha fijado por ahora el presu-/puesto del culto de esa Yglesia en la cantidad de 48000 real. $^{s}$ en/ conservacion y reparacion ordinaria del Templo en la de 4000 y el de la del Palacio Episco-pal en 2000 à cuyas cantida-/des debera a arreglarse en sus gastos, formando V.S. ò el Cabildo/ cuanto à los del Culto, la oportuna relacion de la inversion quel se proponga dar a la suma que para ellos se concede, con arreglo/ à las bases indicadas, à las que deberan atenerse en la parte que/ les toque, cuya relacion remitirá V.S. inmediatamente à este Mi-/nisterio para conocimiento del Gobierno; en la inteligencia 
de quel las cantidades que se inviertan en la conservacion y reparacion del/ Templo y Palacio Episcopal deberan justificarse anualmente antel la Autoridad superior de Hacienda; y que cuando ocurra al-/gun gasto estraordinario deberá V.S. acudir ó dar cuenta á estel Ministerio con justificacion para que por el mismo puedal darse su pago: De orden de S.A. lo digo á V.S: para su inteligen-/cia y efectos consiguientes. I

Lo que manifiesto á V.S. paraqué en su vista se sir-lva formar la relacion de la inversion que se proponga dar á la/ suma concedida para el Culto al efecto de poderla remitir al Go/bierno, quedando V.S.Y. enterado de lo prevenido en cuanto á la/ cantidad asignada à la conservacion y reparacion ordinaria del/ Templo y demas que en la misma se manifiesta./ Dios que/ á V.S.Y. m. ${ }^{s}$ a. ${ }^{s}$ Gerona 20 Octubre de 1842./ Man. ${ }^{l}$ Hurtado V. ${ }^{o}$ G. ${ }^{l}$ Gob. $.^{\text {or }} /^{373}$

5. - Administració dels 48.000 reals, del 19 de desembre de 1842.

Cabildo Catedral de la Santa Yglesia de Geronal

Relación de la inversion que este Cabildo ha dado à los 48000 reales señalados pa-/ra el Culto de esta Santa Yglesia en virtud de la orden de S.A. el Regente del Reyno/ comunicada al Exmo. Sr. Ministro de Gracia y Justicia con fha. 14 de Oct. ${ }^{e}$ del año actual.l

Reales invs.

${ }^{373}$ Ll.R.C. 1840-1843, annex 128. 
En cera para el altar Mayor con arreglo al rito de semidoble, doble mayor, y del $1^{a}$ y $2^{a}$ clase, celebracion de Misas, y demas gastos que ocurran en las fiestas/ del año $11.000 \ldots /$

En cera del Monumento, de las 40 horas, y demas festividades principales de la Se-/mana Santa, Octava de Pascua y Corpus, y otros gastos extraordinarios. $6.000 \ldots /$ Por el Salario de dos Sacristanes, con la obligacion de cuydar de la ropa [...]....2.200.../ Por el Salario de 3 Acolitos á $70 r .^{s}$ al mes cada uno con la obligacion del guardar la Yglesia, ayudar misa à los S.S. Dignidades, Canonigos y asistir à los/Divinos Oficios. $2.920 \ldots /$ Por el Salario de 6 Acolitos $p .^{a}$ ayudar misa à los Beneficiados á $12 r^{s}$ al mes cada uno. $864 \ldots /$

Por la conservacion de ornamentos, vestuarios, vasos sagrados [...].............................5.800.../ Por cera para la Capilla del Sagrario, Viaticos $y$ demas gastos de Parroquia. $2.140 \ldots /$ Por el aceite para las Lamparas. $2.277 \ldots /$

Por incienso.. 360

Por el gasto de Carbon, Leña [...]. $800 \ldots$ Por el salario de dos Monacillos de Coro á 60 $r .^{s}$ al mes cada uno $1.440 \ldots 1$

Por la conservacion de los libros de Coro. $800 \ldots /$

Por el Salario del Capellan silenciero......400.../ Por el Salario de dos Campaneros guardas mayores de la Yglesia á 4r._s diarios cada uno $2.920 \ldots /$ 
Por el Salario del Organista á $6 r^{s}$ diarios. $2.190 \ldots /$

Por el Salario del Manchador del Organo con la obligacion de barrer la/ Yglesia, quitar el polvo á los Retablos, limpiar las escaleras y cemen-/ terio, y demas obligaciones anecsas á 3 $r .^{s}$ diarios. $1.095 \ldots /$

Por el Salario de un Salmista, por haber muerto un Chantre, y hallarsel los otros dos imposibilitados á 6 r. ${ }^{s}$ diarios................2.190.../ Por el Salario del Macero en todo el año........................................................940.../ Por el Salario del Maestro de ceremonias.............................................700.../ Por el Salario del afinador del Organo.................................................900.../ Suma y sigue.......................................46.736.../ Por el Salario del Relojero, $p .{ }^{a}$ cuidar del Relox publico..... $264 \ldots /$ Por gastos de Secretaría y demas dependencias de esta Santa Yglesia. $1.000 \ldots /$ Total. $48.000 \ldots 1$

Por gastos de conservacion y reparacion ordinaria del templo. 4.000.../ Notal

Esta relacion se ha formado con arreglo á las observaciones prevenidas/ por S.A. el Regente del Reyno en la orden comunicada al Exmo. Sr. Minis-/tro de Gracia y Justicia con fha 14 de Octubre ultimo, eliminando los gastos quel la misma previene y reduciendo los que figuran necesariamente casi á unal mitad de los del presupuesto anterior./Gerona 19 Diciembre de $1842 .{ }^{374}$

${ }^{374}$ Ll.R.C. 1840-1843, annex 134. 
6. - “Informe reducido" sobre l'estat de l'orgue i la seva restauració, per l'orguener Honorat Grinda, del 5 de maig de 1826.

\section{Informe reducido}

Lo abaix firmat habent fet lo regoneixement del Orgal gran de esta $S .{ }^{\text {ta }}$ Ygla, dich que es antiquisima la sual construcció; y segóns lo mal estat en que se troban las fustas/ de la sua maquina manifesta ser obra de tres cents anÿs;/ per lo que qualsevol reparo que se fassa momentaneo semprel será inutil y no servirá mes que per multiplicar gastos;/ Segons aixó som de parer:/

Primerament: Si lo M. Yll. ${ }^{e}$ capitol resol que la Obra del Orga quedi á mon/ carrech, será desmontat tot lo Orga: Se farán nous los/ Secréts del Orga gran, lo de la Cadireta, Ecos, y lo de las/Contras; y compostos de cinquanta quatre teclas lo Secret/ gran y lo de la Cadireta, y lo dels Ecos aumentat del deu teclas; per conseguent serán dits Secréts mes amples/y mes llargs a fi de que se puga añadir mes registres, / quedánt á mon charrec y gasto lo fer las flautas novas quel faltarán per lo aument dels registres existéns en dit Orga./

2...Tot lo mecanisme del Orga, teclats, junt lo de las contras/ será fet de nou, acompañat de totas las pessas necessarias./

3...Las manxas serán fetas de una nova construcció molt/ suficients per lo vent del Orga, y afi de que sian re-/parats los mals que pateix dit Orga en lo presént, y quel lo manxador puga manxár ab facilitat./ 
4...Lo factór se obliga á fer novas totas las flautas que se troban/ novas-[sic] inutilisadas y que se trobarán en los registres exis-/ténts; com també en posár corrents las que no sonan per/ falta de vént, y falta de conductos en lo present./

5...Totas las obras mencionadas, serán fetas segóns las/ reglas del art; reservanse lo podér valerse de las fustas y/ pessas vellas que sian en bon estát per fer la dita reparació./

6...Ygualment será a carrech del factór lo recompondrer las/ flautas vellas que son obertas o escaixadas, limpiar, y/ acordár dit Orga; com també empleari bons materials ál satisfacció del M. Yll. ${ }^{e}$ Capitol, y pagár lo fusté, $y$ demés/ obrers ajudants per verificar la dita recomposició del Orga./ [v] Lo M.Yll. ${ }^{e}$ Capitol procurará facilitar al factor/ un puesto en la mateixa Ygla. per treballarlo com-/benient á la dita reparació del Orga; com també/ es donarli manxadó sempre que tinga que afinar./ Per los treballs erxpressats, vestréts de Estañy, fustas,/ pells, $y$ demés materials que se deu emplear en dit Orga,/ tant en lo interior com en lo exterior de la caixa/ demana lo factór cuatre mil lliuras catalanas./ Gerona 5 de Maig de 1826./ Onorato et Fratelli/ Grinda fabricator D'organo/ Regio. ${ }^{375}$

${ }^{375}$ Ll.R.C. 1825-1827, fol. insert a continuació del nº35. 


\section{7. - Pressupost de restauració d'Honorat Grinda, del 8 de maig de 1826.}

Los abajo firmados Canonigos de la S. ${ }^{\text {ta }}$ Yglesia Cathedral de la Ciu-/dad de Gerona como Comisionados del M.Y. Cabildo de la mismal para acordar y realizar la contrata el Organo Mayor de dhâ./ S. ${ }^{\text {ta }}$ Ygl. $^{a}$ en virtud del acuerdo capitular del dia cinco del corrien-/te decimos que, habiendo comparecido al efecto Dn. Honorato Grin-/da Organero Real por si y â nombre de un Hermano Don Anto-/nio Grinda de comun acuerdo hemos convenido con los pactos y/ condiciones siguientes, bajo las cuales los dichos D. ${ }^{n}$ Honorato/ y Antonio se obligan â emprender la obra ô composicion del/ expresado organo, hasta dejarlo corriente $\hat{a}$ satisfaccion del/ M. Y. Cabildo./

Art. ${ }^{\circ} 1 .^{\circ}$... Será obligacion de dhôs Honorato y Antonio el desmontar/ limpiar y acordar perfectamente todo el ogano Mayor de estal Santa Yglesia y poner servible el pequeño para usarlo duran-/te la composicion del Mayor./ Art. ${ }^{\circ} 2 .^{\circ}$... Será tambien la de hacer los secretos del organo grande, del la Cadireta, Ecos, y de las Contras, compuestos el grande y la CadiIreta de cincuenta y cuatro teclas movibles de tres octavas el de los Ecos, de octava y media, el de las contras, y segun estos los/ secretos deberan tener la capacidad para añadir, cuando re-lquiera nuevos registros, quedando dhôs secretos corrientes/ para colocar solamente las flautas cuando se resuelva ha/cerlos./

Art. ${ }^{\circ}$ 3. ${ }^{\circ}$.. Serán obligados dhôs factores en hacer nuevo todo el mecanis-/mo del organo, 
tres teclados de mando movibles y estos de hueso y uno/ de pies acompañado todo de las piezas necesarias paral la perfecta organizacion./

Art. ${ }^{\circ} 4{ }^{\circ} \ldots$ Queda a cargo de los factores el hacer nuevas todas las flau-/tas que faltan por el aumento de los registros, que existen./

Art. ${ }^{\circ} 5{ }^{\circ} \ldots$... Se obligan los mismos a construir un registro nuevo de vo-/ces humanas, como tambien un bordón â la Cadiretal paraque la armonia de esta guarde proporcion con el/ organo grande./

Art. ${ }^{\circ} \quad{ }^{\circ}{ }^{\circ} . .$. Ygualmente los fuelles seran hechos de nuevo y de nueval construccion suficiente para dar al organo el viento quel necesita y à fin de que sean reparados todos los males/ que parece dho organo; y que el afuellador pueda dar el vien-/to con mas facilidad.I

Art. ${ }^{\circ}$ 7. ${ }^{\circ}$... Todas las flautas de los registros existentes que se hallen/ inutilizadas serán hechas de nuevo como tambien poner/ corrientes las que no lo estén por falta de viento ô de conducto/ para ello./

Art. ${ }^{\circ} 8 .^{\circ}$... Todas las flautas que se hallen en el organo en mal estado, / o bien sea por hallarse abiertas ô de cualquier otra maneral no dén el sonido correspondiente à su objeto seran rehechas./

Art. ${ }^{\circ}$ 9. ${ }^{\circ}$... Los factores podrán utilizarse de las maderas y demás ma-/teriales que se hallen en buen estado, y pueden segun esto ser-/vir en el organo./

Art. $^{\circ}$ 10. ... Todo el mecanismo del organo debera ser hecho segun las re-/glas del arte y además deberán emplearse para la repara-/ción 
$y$ construcción tanto de made-/ras como de metal./

Art. $^{\circ}$ 11. ... Para la construcción $y$ recomposición el M.Y.Cabildo no/ debe reconocer otros Artistas que los dos Hermanos D. ${ }^{n}$ Ho-/norato y Antonio Grinda y por consiguiente será del cargo de estos el cuydarse de todo lo que pertenezca al ramol de Carpinteria, herrería y demás utiles necesarios paral completar dhâ obra, y unicamente será de cargo del Ca-/[v]bildo el proporcionarles afuellador para la afinacion cuan-/do lo necesiten./

Art. ${ }^{\circ}$ 12. ... Todos los mencionados trabajos serán hechos con la perfecci-lon del arte $\hat{a}$ satisfaccion del M.Y. Cabildo y con la aprobalción de peritos si fuese necesario siendo de cuydado de los/factores que todas las flautas tengan el sonido agradablel resultando en el todo de la construccion la armonia sono-/ra que pide el instrumento, y magestad de la ta $^{\text {ta }} \mathrm{Ygl}^{\mathrm{a}}{ }^{\prime}$ Cathedral./

Art. ${ }^{\circ}$ 13. ... El E.Y. Cabildo atendiendo $\hat{a}$ cuanto va expresado en los/ articulos antecedentes se obliga à satisfacer $\hat{a}$ los Hermanos/ D. ${ }^{n}$ Honorato y Antonio Grinda la cantidad de cuatro Mil/ libras Catalanas, en esta forma: las dos mil libras se les/ iran entregando à proporcion de que vayan adelantan-/do los trabajos, y las restantes dos mil se les entregarán/ luego que hayan dejado concluida la obra â satisfac-/cion del M.Y. Cabildo./

Art. ${ }^{\circ}$ 14.... Asi mismo se obliga el M.Y. Cabildo a facilitarles la pri-/mera pieza de la Sala 
Capitular paraque en ella pon-/gan su laboratorio, ô taller./

Art. $^{\circ}$ 15. ... Los expresados factores se obligan a empezar la obral cuanto antes y seguirla sin interrupcion, y sin quel puedan empezar otra obra que impida la de esta/ contrata./

Art. $^{\circ}$ 16. ... Los mencionados Comisionados en representacion/ del M.Y. Cabildo, y los expresados D. ${ }^{n}$ Honorato y Antonio/ [v] Grinda se obligan mutuamente â las condiciones esta/blecidas en los articulos de esta contrata, pudiendosel demandar igualmente en juicio, siempre que por/ cualquiera de las partes se faltase â lo que en ella/ se estipula; y para su mayor validez y firmeza dan/ $\hat{a}$ este papel privado toda la fuerza que por derecho se per/mite, y como si fuera otorgado el contrato en escritu-/ra publica; para lo que lo firmamos todos en la Ciudad/ de Gerona â los dias 8 de Mayo del año Mil ochocien-/tos veinte y seis./ Por indisposicion del S. ${ }^{\text {or }}{ }^{n}{ }^{n}$ Fran. ${ }^{\text {co Juncal }}$ Juan Pons Canonigo/ Jaime Codorniu Can. ${ }^{\circ}$ Man. ${ }^{l}$ Hurtado Com. $\%$ Antonio Guiu Pbro. Org. ${ }^{\text {ta } / \text { Comicion. }}{ }^{d o} /$ Onorato et antonio Grinda fratelli/ Fabricator D'organi Regio. ${ }^{376}$

\section{8. - Acta del canvi de lloc de l'orgue, del $\mathbf{1 5}$ de juny de 1827.}

Se leyó la siguiente proposicion del $S^{r}$ Hurtado/ (n. ${ }^{\circ}$ 6) :

Yllmo S.: En el Cab. ${ }^{\text {do }}$ anterior dixe à V.S: que/ seria conveniente una nueva Com. ${ }^{\text {on }}$, para

$\overline{{ }^{376} \text { Ll.R.C. 1825-1827, annex }}{ }^{\circ} 59$. 
quel con los S.S. Juncá y Guiu como facultativos,/ llevase à cumplimiento la res. ${ }^{\text {on }}$ que V.S. tomasel sobre el plan que debiera seguirse en la obra del/ Organo; no habiendo permitido el tiempo acor-/dar sobre esta mi proposicion [...]/

Res. $^{\text {on }}$ Despues de heberse subcitado una acalorada/ cuestion sobre si debia continuarse

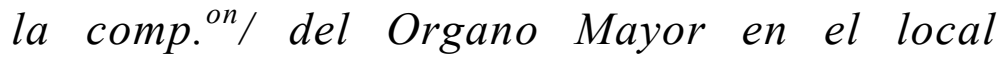
actual, ò habial de colocarse detras del Coro, con arreglo al plan/ presentado por el Organero; dijo el Sor. Presid. ${ }^{\text {te }}$ / habia presentido que la colocacion del organol detras del Coro, no era de la aprovacion del algunos facultativos de Musica, y siendo este/[fol. 2v] negocio de importancia, en que regularmente no/ entenderian mucho los S.S. Capitulares, era del parecer se nombrase una Comision para que se in-/formase sobre el asunto y reportase el resultado./

El S. ${ }^{r} \quad$ Hurtado dixo, que por la parte de Musical aprobaban el nuevo plan los facultativos mas inteli-/gentes, como el $S$. Juncà, el Organista Guiu y Mtro./ de Capilla y otros varios: y por lo que toca al nuevo/ plan presentado por el Organero (que ha estado de mani-/fiesto) dijo, habia consultado los Maestros artistas,/ de quienes ha merecido la aprovacion de dicho plan./

Despues de haber hablado otros S.S. en pro/ y contra, se procedio a la votacion nominal à pro-/puesta del S. ${ }^{r}$ Presid. ${ }^{\text {te }}$, quien votó que se nombrasel una Com. ${ }^{\text {on }}$ segun tenia propuesto, con cuyo voto sel conformaron los S.S. Cuffi, Codorniu, Ferrer, Dagas,/ Arnautó, Velado menor, Blanco y Mató./ 
El S. ${ }^{r}$ Junca, manifesto que la colocacion del/ organo segun el nuevo plan, detras del Coro, era muy/ útil para la Musica, particularmente para la Capilla,/ porque reunida como lo estaria en este caso, resulta/ mas uniformidad y dulzura y ademas que el or-/gano podrá suplir algun instrumento ò instrumentos/ que falten à la Capilla con su acompañamiento, que no/ puede verificarse actualmente por su mucha distancia,/ bajo cuyo concepto, votó que se colocase el Organo/ detras del Coro con arreglo al nuevo plan, habi-/endose conformado con su voto los S.S. Rodo, Costas,/ Campillo, Toronel, Bertran, Pau, Gasch,/ [fol.3] Hurtado, Rodrigo, Gonzalea, Granges, Abrich, Lan-/ dache, Serch, Bonet, Delgar, Soler y Tristany./

El S. ${ }^{\text {or }}$ Presid. ${ }^{\text {te }} y$ algunos otros Capitulares pidieron/ se les hiciese copia de esta acta y de la en que se hizo/ la primera Comision del Organo./

Res. ${ }^{\text {on }}$ Libreseles por el Canonigo Sec. ${ }^{\circ}$ las copias que pidieran. ${ }^{377}$

\section{9. - Carta de'n Mateu Ferrer, del 24 de març de 1830.}

[1]

Yll. ${ }^{\text {mo }}$ Señor/

Los $q^{e}$ abajo firmamos Comisionados por V.S.Y./ y el factor para hacer el reconocim. ${ }^{\text {to }}$ del Organo/ nuevo de esta St. ${ }^{a}$ Yglesia damos la siguiente/ Censura./

Primeram. ${ }^{\text {te }}$, hemos registrado todo el Organo/ interior, y exteriorm. ${ }^{\text {te }}$ con toda prolijidad/su

$\overline{{ }^{377} \text { Ll.R.C. 1827-1829, fol. } 2 .}$ 
mecanismo, confrontando con la nota de los reIgistros, y el estado, q. ${ }^{e}$ tenia el Organo ante/riorm. ${ }^{\text {te }}$ dada por D. ${ }^{n}$ Antonio Guiu, como/ tambien con la contrata hecha con el factor Grinda,/ de todo lo q. ${ }^{e}$ resulta, $q .{ }^{e}$ el Org. ${ }^{n o}$ esta hecho con/ todas las reglas del arte, con solidez, y pulidez/ en todos sus materiales, hallandose cumplida/ la Contrata por el factor á tenor de la notal de lo q. ${ }^{e}$ antes tenia, y los registros de que sel componia. El tono de todos los registros que com-/ponen dicho Organo es bueno, y sonoro, y aunquel parece algo flaco es por la grande nave de la/ Yglesia, que absorve las voces, y esparce el ecol por los quatro angulos, lo que puede remediarsel en gran parte, tapando por dentro las tres caras/ [v] de tras coro, y laterales, de que resultarál las ventajas que el Organo estará preserva-/do de los Ayres, y polvo, conservara mejor/ su afinacion y despedira el Eco mas reu-/nido aumentando su voz, haciendo tambien/ unas haberturas en las puertas de la/ Cara del coro si fuese necesario./ En quanto al registro de voces huma-/nas, aun que le hallamos bueno, y bien/ construido, no puede hacer su efecto por las/ razones dadas, y por que siendo este un/ registro, que deve oirse de larga distancial encerrado en una caja, que por medio del resorte se abre y cierra, hace sus fuer-/tes y pianos que es su alma, sin cuias/ circunstancias nunca puede brillar, ni cau-/sar el debido efecto por su delicadeza./

Tambien hemos registrado y examina-/do flauta por flauta los catorce registros/nuevos, que ha hecho, y colocado el factor/ ademas de la obligacion de la Contrata,/los que estan bien 
construidos segun reglas/ del arte, y tienen buen tono; y somos de/parecer que deve V.S.Y. quedarse con ellos,/ [2] porque tanto los Nazardos del Organo Grande,/ como la Corneta de la Cadireta son indispen-/sables por ser de los que mas se deben usar/ y los restantes igualm. ${ }^{\text {te }}$ para el lucim. ${ }^{\text {to }} /$ del Organo, y Organista, y el precio, quel pide el Organero por dichos catorce regis-/tros nuevos es el mas equitativo, y barato,/ que puede darse./ En quanto á todo lo demas del Org. ${ }^{n o}, /$ no encontramos cosa, que notar debiendo/ hacer presente, que la colocacion, y dis-/tribucion del mecanismo tiene mucho/ merito, porque á un golpe de vista puedel persibirse toda la maquinaria, lo quel no sucede ordinariam. ${ }^{\text {te }}$ en los demas/ organos./Gerona 24 Marzo de 1830/ Mateo Ferrer [amb la rúbrica] JJose Barba Pbro. [amb la rúbrica]. ${ }^{378}$

${ }^{378}$ Ll.R.C. 1829-1831, annex no52. 